\title{
EDIÇÕES PAULINAS: \\ RELIGIÃO, POLÍTICA E PRÁTICA EDITORIAL \\ (1962-1994)
}

Versão corrigida 
UNIVERSIDADE DE SÃO PAULO

FACULDADE DE FILOSOFIA, LETRAS E CIÊNCIAS HUMANAS

DEPARTAMENTO DE HISTÓRIA

PROGRAMA DE PÓS-GRADUAÇÃO EM HISTÓRIA ECONÔMICA

\section{EDIÇÕES PAULINAS: \\ RELIGIÃO, POLÍTICA E PRÁTICA EDITORIAL \\ (1962-1994)}

\section{Versão corrigida}

Dissertação apresentada ao Programa de Pós-Graduação em História Econômica do Departamento de História da Faculdade de Filosofia, Letras e Ciências Humanas, da Universidade de São Paulo, como parte dos requisitos para obtenção do título de Mestre em História.

Área de Concentração: História Econômica

Orientadora: Prof. ${ }^{a}$ Dr. ${ }^{a}$ Marisa Midori Deaecto

São Paulo 
Autorizo a reprodução e divulgação total ou parcial deste trabalho, por qualquer meio convencional ou eletrônico, para fins de estudo e pesquisa, desde que citada a fonte.

Catalogação na Publicação

Serviço de Biblioteca e Documentação

Faculdade de Filosofia, Letras e Ciências Humanas da Universidade de São Paulo

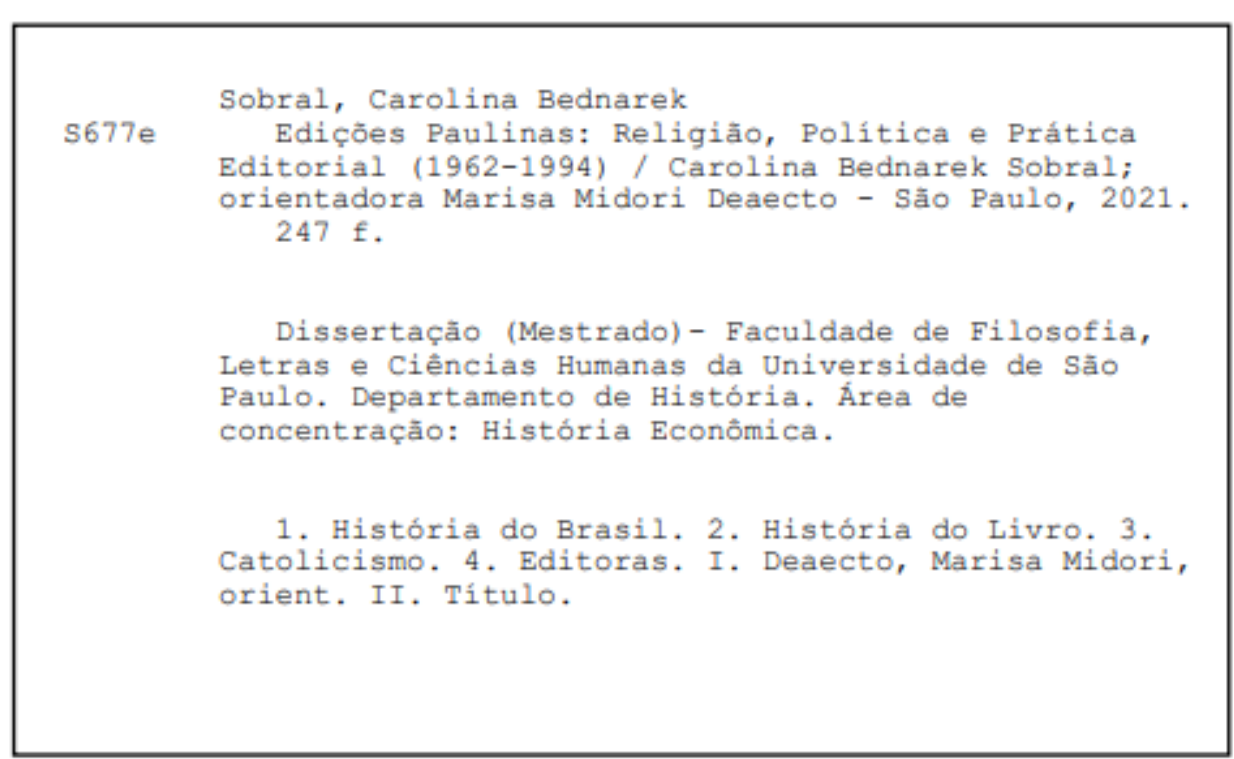




\section{ENTREGA DO EXEMPLAR CORRIGIDO DA}

\section{DISSERTACÃO/TESE}

\section{$\underline{\text { Termo de Ciência e Concordância do (a) orientador (a) }}$}

Nome do (a) aluno (a): Carolina Bednarek Sobral

Data da defesa: 28/05/2021

Nome do Prof. (a) orientador (a): Marisa Midori Deaecto

Nos termos da legislação vigente, declaro ESTAR CIENTE do conteúdo deste EXEMPLAR CORRIGIDO elaborado em atenção às sugestões dos membros da comissão Julgadora na sessão de defesa do trabalho, manifestando-me plenamente favorável ao seu encaminhamento e publicação no Portal Digital de Teses da USP.

São Paulo, 09/07/2021.

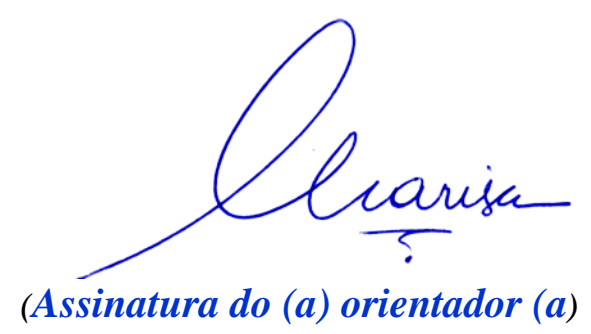


À memória de Valdete de Matos Bednarek 
"Quando os livros foram substituídos pelo Livro, os homens foram tomados por uma certa vertigem. Para todo homem que tenta penetrar neste espaço protegido, é forte a tentação de se encontrar na posição do Todo-Poderoso. Cada qual, crente ou descrente, quer escrever seu livro, nostalgia do livro único. [...]

O crente sem Deus está condenado a escrever por si próprio seu livro".

Michel Melot, Livro, 
SOBRAL, Carolina Bednarek. Edições Paulinas: Religião, Política e Prática Editorial (1962-1994). Dissertação de Mestrado apresentada à Faculdade de Filosofia, Letras e Ciências Humanas da Universidade de São Paulo para obtenção do título de Mestre em História, 2021.

Aprovado em: 28 de maio de 2021.

Orientadora: Profa. Dra. Marisa Midori Deaecto

Banca Examinadora:

Prof. Dr. Lincoln Ferreira Secco

Universidade de São Paulo

Julgamento Assinatura

Prof. Dr. João Cesário Leonel Ferreira Universidade Presbiteriana Mackenzie Julgamento Assinatura

Prof. Dr. Flamarion Maués Pelúcio Silva Universidade Federal de São Paulo Julgamento Assinatura 
SOBRAL, Carolina Bednarek. Edições Paulinas: Religião, Política e Prática Editorial (1962-1994). Dissertação de Mestrado apresentada à Faculdade de Filosofia, Letras e Ciências Humanas da Universidade de São Paulo para obtenção do título de Mestre em História, 2021.

Esta pesquisa busca compreender o projeto editorial das Edições Paulinas no Brasil no período 1962-1994, em sua relação com a Igreja Católica e com o mercado editorial e a sociedade brasileira. Inicia analisando seu processo de formação, das origens na Itália, passando pela estruturação de seu catálogo, gráficas e livrarias, às reformas empreendidas nas décadas de 1960 e 1970, com a sistematização da comunicação católica estabelecida pelo Concílio Vaticano II e, no Brasil, pela CNBB. Aborda, também, sua inserção no mercado editorial brasileiro a partir de estratégias e práticas editoriais bem definidas. Por fim, examina mais detidamente suas coleções sobre Teologia da Libertação e comunidades eclesiais de base, que, no contexto de desagregação da ditadura militar, possuíam um projeto religioso, político e social para o país, que tem como marco final a publicação da Edição Pastoral da Bíblia.

Linha de Pesquisa: Economia da Cultura Palavras-chave: Edições Paulinas; Igreja Católica; Mercado Editorial Brasileiro; Teologia da Libertação; Comunidades Eclesiais de Base 
SOBRAL, Carolina Bednarek. Edições Paulinas: Religion, Politics and Publishing Practice (1962-1994). Master's Thesis - Faculdade de Filosofia, Letras e Ciências Humanas, Universidade de São Paulo, São Paulo, 2021.

This research aims to understand the editorial project of a Brazilian catholic publisher, Edições Paulinas, between 1962-1994, and its relation with the Catholic Church and Brazilian publishing marketing and society. First, we analyze the publishing house formation: its Italian origins, the structuring of its catalog, printing factories and bookstores, to the reforms undertaken in the 1960s and 1970s, when Second Vatican Council and the Episcopal Conference of Brazil organize catholic communication. We also address its insertion in the Brazilian publishing marketing based on well-defined publishing strategies and practices. Finally, we examine at greater length its books series on Liberation Theology and basic ecclesial communities, which, in the context of disintegration of military dictatorship, had a religious, political and social project, whose final sign is the publication of the Bible's Edição Pastoral.

Keywords: Edições Paulinas; Catholic Church; Brazilian Publishing Market; Liberation Theology; Basic Ecclesial Communities 


\section{Sumário}

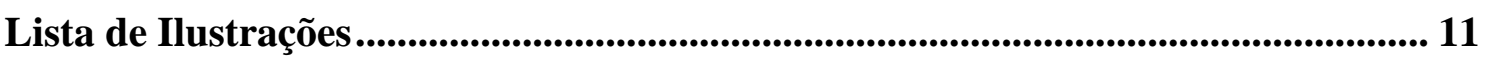

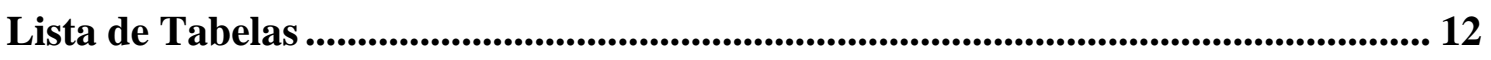

Lista de Abreviaturas e Siglas ........................................................................... 13

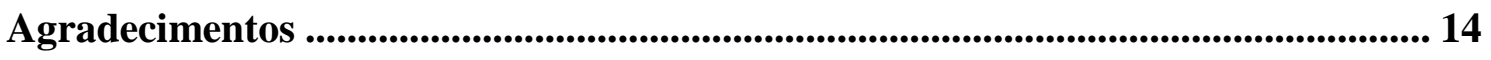

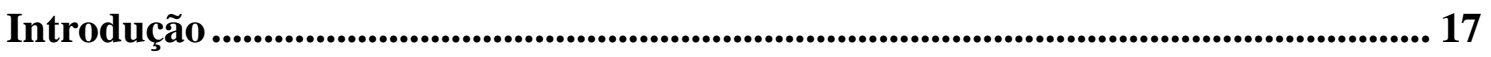

Capítulo 1_Formação das Edições Paulinas ................................................................ 27

1.1. Origens: "Difundir a Boa Imprensa e Combater a Má".................................. 27

1.2. 1962: Mudanças de Rumos. A Abertura para um Novo Mundo ..................... 54

Capítulo 2.A Igreja e a Comunicação após o Concílio Vaticano II ............................. 71

2.1. "Entre as Maravilhosas Invenções da Técnica": o Concílio Vaticano II .................. 71

2.2. A CNBB: Política e Edição ……………........................................................ 78

Capítulo 3.As Edições Paulinas no Mercado Editorial Brasileiro ......................... 100

3.1. Um Campo Editorial Católico? ..................................................................... 100

3.2. Edições Paulinas: Estratégias e Práticas Editoriais ......................................... 113

Capítulo 4.Um Projeto Editorial e Político (1978-1994) ........................................ 140

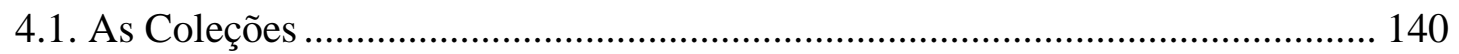

4.2. Ler a Bíblia nas Comunidades Eclesiais de Base ........................................... 180

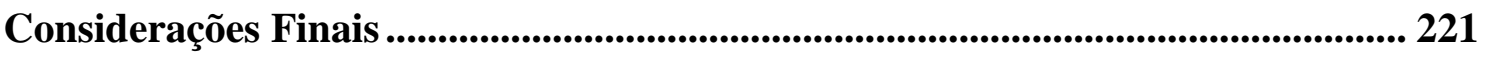

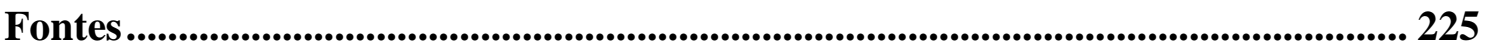

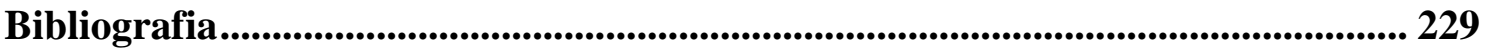




\section{Lista de Ilustrações}

Figura 1. Cabeçalho do La Squilla, n. 37, 29.11.1911 „................................................. 36

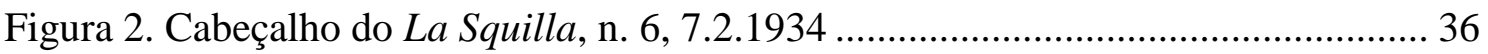

Figura 3: Propaganda da Livraria das Edições Paulinas na Praça da Sé, São Paulo...... 41

Figura 4: As Marcas da Editora ao Longo do Tempo ............................................... 51

Figura 5: Capas da Série Primavera e da Nova Série Primavera.................................... 51

Figura 6: Anúncio das Edições Paulinas na Folha de S. Paulo, 30.6.1985.................. 115

Figura 7: Capa de Hiroito de Moraes Joanides, Boca do Lixo ..................................... 117

Figura 8: Capas de Livros de Padre Zezinho.............................................................. 130

Figura 9: Capa de Wilson João, O Francisco que Está em Você................................ 135

Figura 10. Volumes da coleção Libertação e Teologia ............................................... 145

Figura 11. Capas de Franz Hinkelammert, As Armas Ideológicas da Morte ................ 151

Figura 12: Capa de Walmir Fernandes Brandão, Panela de Opressão......................... 154

Figura 13: Capa de Jorge Boran, Juventude: O Grande Desafio ................................ 157

Figura 14: Ilustração em Jorge Boran, Juventude: O Grande Desafio ........................ 159

Figura 15. Capa da Bíblia Sagrada: Edição Pastoral ............................................... 186

Figura 16: Capa de Carlos Mesters, Bíblia: Livro Feito em Mutirão............................ 195

Figura 17: Capas da Coleção Como Ler a Bíblia ............................................................. 204 


\section{Lista de Tabelas}

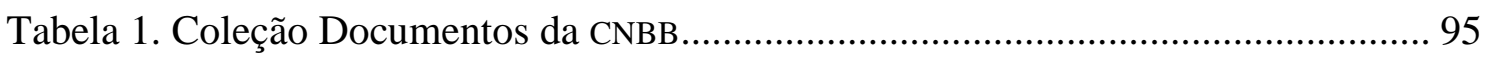

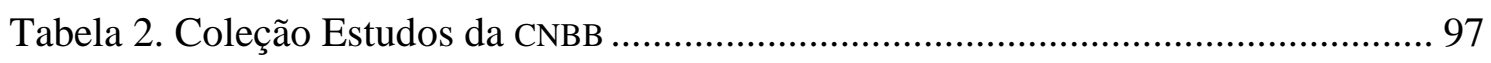

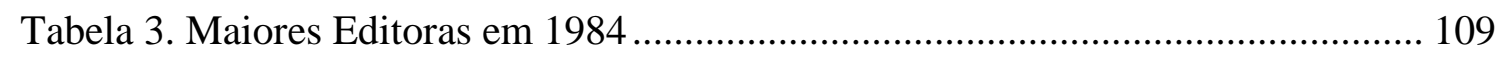

Tabela 4. Instituições Parceiras das Edições Paulinas (1978-1994) ............................. 123

Tabela 5. Coleções sobre Teologia da Libertação e Comunidades Eclesiais de Base ......... 171

Tabela 6. Lista de Preços de Bíblias das Edições Paulinas, 1988..................................183

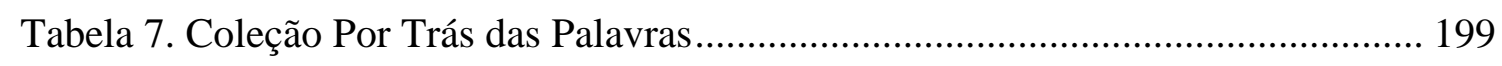

Tabela 8. Coleção Como Ler a Bíblia ...................................................................... 212

Tabela 9. Subtítulos da Bíblia Pastoral e da Coleção Como Ler a Bíblia .................... 217 


\section{Lista de Abreviaturas e Siglas}

\begin{tabular}{|c|c|}
\hline AJC & Associação dos Jornalistas Católicos \\
\hline Cebi & Centro de Estudos Bíblicos \\
\hline CEBs & Comunidades Eclesiais de Base \\
\hline Cehila & Comissão de Estudos de História da Igreja na América Latina e no Caribe \\
\hline Celam & Conselho Episcopal Latino-Americano \\
\hline Ceris & Centro de Estudos Religiosos e de Investigações Sociais \\
\hline CNBB & Conferência Nacional dos Bispos do Brasil \\
\hline СРT & Comissão Pastoral da Terra \\
\hline C.S.sp & Congregação do Espírito Santo \\
\hline CPV & Centro de Pastoral Vergueiro \\
\hline DEI & Departamento Ecuménico de Investigaciones \\
\hline ECA-USP & Escola de Comunicações e Artes da Universidade de São Paulo \\
\hline fsp & Pia Sociedade Filhas de São Paulo \\
\hline Itesp & Instituto Teológico São Paulo \\
\hline JOC & Juventude Operária Católica \\
\hline JUC & Juventude Universitária Católica \\
\hline MEB & Movimento de Educação de Base \\
\hline Proep & Propaganda e Promoção de Edições Paulinas \\
\hline PCdoB & Partido Comunista do Brasil \\
\hline PUC & Pontifícia Universidade Católica \\
\hline PT & Partido dos Trabalhadores \\
\hline $\mathrm{RCC}$ & Renovação Carismática Católica \\
\hline SAB & Serviço de Animação Bíblica \\
\hline $\operatorname{scj}$ & Congregação dos Sacerdotes do Sagrado Coração de Jesus \\
\hline Sepac & Serviço à Pastoral da Comunicação \\
\hline SNI & Serviço Nacional de Informações \\
\hline ssp & Pia Sociedade de São Paulo \\
\hline TFP & Tradição, Família e Propriedade \\
\hline $\mathrm{UCBC}$ & União Cristã Brasileira de Comunicação \\
\hline Unimep & Universidade Metodista de Piracicaba \\
\hline USP & Universidade de São Paulo \\
\hline
\end{tabular}




\section{Agradecimentos}

À Capes, Coordenação de Aperfeiçoamento de Pessoal de Nível Superior, pela bolsa concedida, fundamental para a realização desta pesquisa.

A Marisa Midori Deaecto, que orientou esta pesquisa (e esta pesquisadora) com toda sua experiência, erudição e generosidade.

Aos membros da banca, professores Lincoln Secco, João Leonel e Flamarion Maués, pela gentil disposição de ler e enriquecer com seus comentários este trabalho.

Aos professores cujas disciplinas de pós-graduação contribuíram muito com as reflexões aqui propostas: Nelson Schapochnik, Marcos Napolitano, André Singer, Ricardo Mariano e Ozias Paese Neves. À professora Sandra Reimão, pela disponibilidade de sempre. E ao professor Plinio Martins Filho, que, além de todo o apoio, também me possibilitou acesso aos exemplares do jornal Leia Livros.

Às irmãs paulinas Ilanyr Felipe Costa e Vera Ivanise Bombonatto, aos padres paulinos Luiz Miguel Duarte e Claudiano Avelino dos Santos, aos membros das editoras Paulus e Paulinas, em especial a Ramires Henrique de Andrade, Valéria Peixoto e Danilo Matos, e às bibliotecárias da Fapcom.

A Sandra Aparecida Pereira, do Arquivo Edgard Leuenroth, (AEL-Unicamp), pelo auxílio valiosíssimo e sem precedentes. A Fernando José Clark Xavier Soares, pela simpatia e boa vontade.

Aos amigos e colegas de estudos que me acompanham. Além de todas as conversas, leituras e sugestões, cada um à sua maneira contribuiu de forma especial durante esse processo: Beatriz Tavares Silva, Bruna Oliveira, Fabiana Marchetti, Felipe Castilho de Lacerda, Fernando Dizzio, Gabi Salvatto, Gabriel Fabril, Graziela Mazzeo, 
Isadora Aragão Pereira, José Victor Neves, Leila Ferreira de Carvalho, Mariana Cantuária, Vinícius Juberte, Umberto Ribeiro, Vivian Nani Ayres.

E, por fim, agradeço à minha mãe, Cristina Bednarek Sobral, ao meu pai, José Milton Sobral, e ao meu irmão, Luciano Bednarek, por tudo. 


\section{EDIÇÕES PAULINAS: \\ RELIGIÃO, POLÍTICA E PRÁTICA EDITORIAL \\ (1962-1994)}




\section{Introdução}

Desde a década de 1930, uma empresa estabelecida por imigrantes italianos no Brasil tomou para si a responsabilidade de produzir e comercializar livros católicos para amplas parcelas da população. Ao longo das décadas, o empreendimento foi se expandindo, absorvendo membros brasileiros e, após o Concílio Vaticano II, que se inicia em 1962, a editora já possui uma estrutura suficiente para implementar reformas e atender às novas demandas da Igreja Católica. Sob a marca das Edições Paulinas, as obras alcançaram de fato um grande público e repercutiram na cultura religiosa e política nacional.

A editora era mantida pelos padres e irmãos da Pia Sociedade de São Paulo e pelas irmãs da Pia Sociedade Filhas de São Paulo - congregações "paulinas"1 -, que unificam suas publicações sob uma mesma marca em meados da década de 1940. Essa marca, Edições Paulinas, dura até 1994, quando há uma separação definitiva entre as seções feminina e masculina, que passam a formar as editoras Paulinas e Paulus, respectivamente ${ }^{2}$.

Embora o trabalho editorial em si se desse, em geral, separadamente e em espaços físicos distintos, paulinos e paulinas tinham projetos conjuntos e suas congregações e editoras mantinham relações estreitas. Compartilhavam uma mesma marca, os livros

\footnotetext{
${ }^{1}$ Até 1983, quando foi promulgado o mais recente Código de Direito Canônico, havia uma distinção na Igreja Católica entre ordens e congregações religiosas. Os membros das primeiras fariam "votos solenes", enquanto os da segunda, "votos simples". Tanto a Pia Sociedade de São Paulo quanto a Pia Sociedade Filhas de São Paulo sempre foram congregações. O Código de 1983 aboliu essa distinção, tratando todos igualmente ora como "Institutos de Vida Consagrada" ora como "Institutos Religiosos", dos quais "congregação" tornou-se sinônimo. Por esses dois motivos, ao longo deste trabalho será utilizado o termo "congregações" paulinas.

${ }^{2}$ Por isso, neste trabalho as referências a Edições Paulinas remetem à empresa ainda unificada, como marca. Por conta da divisão interna entre homens e mulheres, houve um esforço de pesquisa para especificar, até onde foi possível, quais trabalhos eram realizados pelas irmãs paulinas e quais pelos padres e irmãos paulinos, mesmo que publicassem, vendessem e divulgassem sob um nome comum.
} 
editados por uns eram vendidos em livrarias mantidas pelas outras (e vice-versa), e estavam inseridos em um mesmo campo editorial. Muitos autores e instituições, por exemplo, publicavam pelas duas editoras ${ }^{3}$.

É justamente nesse interregno, entre o período do Concílio Vaticano II (19621965) e a reforma de 1994, que as Edições Paulinas atuantes no Brasil vivem seu auge editorial e comercial. Após 1968, com a Conferência de Medellín, em que os bispos latino-americanos assumem uma "opção preferencial pelos pobres" e passam a tratar dos problemas sociais de forma mais combativa (isto é, para além da prática da caridade, há a crítica às causas da pobreza) ocorre também a elaboração da Teologia da Libertação, que via como objetivo do cristianismo libertar o "povo de Deus" das explorações e injustiças ainda neste mundo, terreno e material. Essas explorações não seriam expressão do desejo divino, mas socialmente criadas. Para compreendê-las, mesclam categorias da teologia às das ciências sociais e passam a interpretar o mundo em uma chave de esquerda.

Ao mesmo tempo, expandiram-se durante a ditadura militar as chamadas comunidades eclesiais de base (CEBs), especialmente nas periferias das grandes cidades e nas zonas rurais. Essa forma de associação, por ocorrer geralmente nas igrejas e contar com o apoio do pároco, esteve, até certo ponto, menos sujeita à repressão. Conforme os setores progressistas da Igreja começam a trabalhar com essas "bases", isto é, diretamente com os leigos da paróquia, em ocasiões que não a missa, essas comunidades se politizam, muito pela influência da Teologia da Libertação (e, aos poucos, de outros movimentos

\footnotetext{
${ }^{3}$ Como veremos, pelo caráter excepcionalmente conservador da Igreja Católica, em que homens e mulheres devem desempenhar suas vidas separadamente, desde a formação das congregações paulinas essa separação foi bem marcada. O que não impedia que houvesse funcionárias leigas na empresa dos paulinos e funcionários leigos na das paulinas, sobretudo a partir da maior profissionalização e liberalização ocorrida na década de 1970. Mais tarde, já como empresas consolidadas, houve momentos de maior ou menor aproximação entre as duas congregações. Enquanto em 1979 houve uma colaboração estratégica, com consequências comerciais positivas, o auge das tensões ocorreu no período entre 1994 e 1995, imediatamente após a separação e mudança da marca.
} 
sociais que se reorganizavam), especialmente sobre seus líderes. Pelo alto número dessas comunidades, na década de 1970 a própria hierarquia da Igreja vê nelas um potencial de evangelização e de manutenção de membros dentro da instituição (já que o momento coincidia com o crescimento das igrejas evangélicas neopentecostais).

É nessa segunda metade da ditadura militar, especialmente a partir de 1978, que as Edições Paulinas transformam radicalmente seu catálogo e passam a publicar, sobretudo, obras sobre Teologia da Libertação e comunidades eclesiais de base. Para compreender essa atuação editorial, este se trabalho se propõe a: 1. Observar como se deu a formação das Edições Paulinas, de sua criação às reformas empreendidas a partir dos anos 1960, por meio das suas primeiras publicações e estratégias editoriais, além da formação religiosa e intelectual de seus membros; 2. Entender as transformações ocorridas na comunicação católica a partir do Concílio Vaticano II e, no Brasil, como a CNBB liderou esse processo, contando, também, com a estrutura editorial das Edições Paulinas; 3. Observar como a empresa se colocava no mercado editorial brasileiro no período estudado, por meio de estratégias e práticas editoriais específicas; 4. Por fim, abordar as principais coleções e projetos editoriais empreendidos nos anos $1970 \mathrm{em}$ relação à Teologia da Libertação e às comunidades eclesiais de base, incluindo a Edição Pastoral da Bíblia, com vistas a lançar luz, também, sobre o projeto de sociedade que a Igreja progressista possuía para o Brasil.

O primeiro passo da pesquisa foi um levantamento dos títulos e coleções publicados pela editora. Esse esforço de compreender o catálogo das Edições Paulinas ocorreu de diversas formas. Entre outras, pela própria consulta aos paratextos dos livros, já que, quando um livro é publicado em uma coleção, geralmente traz uma lista dos demais volumes desta. Mas, para uma maior sistematização dos dados, o melhor método disponível foi uma listagem das obras disponíveis no acervo da Biblioteca Nacional. Por conta da 
limitação dessas fontes, já que os registros são pouco numerosos até o fim da década de 1970, adotamos, para esse catálogo montado a partir da Biblioteca Nacional, um recorte entre 1978 e 1994, quando saem as últimas publicações sob a marca Edições Paulinas.

Optamos por esse levantamento pois foi a forma de reunir um maior número de informações, já que não foi possível a consulta a antigos catálogos da editora, por exemplo. Tivemos acesso a alguns livros conservados no depósito da editora Paulus, onde também pudemos consultar alguns documentos (contratos de edição, tradução e correspondências esparsas) do arquivo do departamento de direitos autorais - o que contribuiu para a compreensão de questões relativas às práticas editoriais. Porém, não tivemos acesso a registros financeiros ou a números como os das tiragens. Tampouco foi permitida a consulta a arquivos da seção feminina da congregação. Por outro lado, foram valiosos, especialmente para o Capítulo 1, depoimentos concedidos por membros da congregação.

Além dos livros publicados pela editora ${ }^{4}$ - que pudemos consultar em variadas bibliotecas e arquivos ou adquirir em $\operatorname{sebos}^{5}-$, outra fonte relevante foi encontrada nos periódicos (jornais e revistas) de ampla circulação, espaços nos quais as Edições Paulinas buscaram se inserir desde suas primeiras décadas de atuação, já que a publicidade era parte importante de seu objetivo de atingir as grandes massas.

\footnotetext{
${ }^{4}$ Optamos por citá-los, ao final, junto à bibliografia geral do trabalho, reservando a seção "Fontes" aos documentos não publicados, jornais, revistas e depoimentos pessoalmente concedidos.

${ }^{5}$ Uma curiosidade em relação aos exemplares vendidos em sebos é a maior possibilidade de se deparar com marginálias de antigos donos (que geralmente são menos frequentes e mais tímidas em livros de bibliotecas). Nosso exemplar de Teologia da Libertação: Ensaio de Síntese (autoria de Segundo Galilea, 2. ed., Edições Paulinas, 1979) por exemplo, teve ao menos dois leitores anteriores, e ambos grifavam e anotavam o significado de algumas palavras. Um deles atribuiu a "marxismo" a definição "comunismo" e a "herodianas" a definição "malvadas, cruéis". O outro anotou os significados de "opúsculo" ("pequeno livro"), "práxis" ("prática"), "homilético" ("hábito de bem falar, teoria da eloquência"), "altruístas" ("humanistas"), "escatológica" ("doutrina referente aos últimos fins do universo e da humanidade, empregada sobretudo pelos teólogos para designar os problemas do 'fim do mundo"') e circulou diversas ocorrências de "ambíguo", para as quais não registrou nenhuma definição. Como sugestão para futuras pesquisas, essa espécie de fonte, que requer métodos específicos de análise, se apresenta como uma forma de se aproximar dos hábitos de estudo e dos usos cotidianos que se fazia dessas publicações, por exemplo, nas comunidades eclesiais de base (o que exigiria, também, consulta a arquivos de procedência conhecida).
} 
Além das fontes, trabalhos anteriores sobre as Edições Paulinas e as editoras católicas brasileiras foram referências bibliográficas fundamentais. A maior parte das pesquisas a respeito da atuação da editora no século XX foi realizada pelas mulheres da congregação. Há estudos específicos realizados sobre a revista Família Cristã, das paulinas, estudada pelas também irmãs Maria Natividade do Nascimento ${ }^{6}$ e Joana Puntel $^{7}$. Com um recorte mais restrito, há também uma pesquisa feita externamente à congregação ${ }^{8}$. Mas, entre os trabalhos realizados pelas próprias paulinas, a que mais contribuiu para a presente pesquisa foi o de Iraci Maria Didoné, que realizou no final da década de 1980 mestrado em comunicação a respeito das publicações das Edições Paulinas destinas às comunidades eclesiais de base. Embora o título se refira também às CEBs como autoras ${ }^{9}$, esse elemento praticamente não é abordado por Didoné, e o foco de sua pesquisa se concentra nos embates entre a Igreja politizada à esquerda - com a qual a autora se identifica - e a "espiritualidade intimista". A conclusão de Didoné é a de que, para conquistar um público mais amplo, as publicações das CEBs deveriam incorporar mais elementos "populares", para além de uma racionalidade exacerbada: "imaginário, sonho, festa, romance, dança, alegria"10. Didoné parte de um ponto de vista interno à editora, e sua pesquisa foi importante sobretudo para compreendermos algumas práticas editorais, como o processo de seleção de originais.

\footnotetext{
${ }^{6}$ NASCIMENTO, Maria Natividade Pereira do. A Religiosidade Popular na Revista Família Cristãa: Uma Análise das Matérias que Aparecem na Seção Cultura Popular das edições de 1980 a 1981 . Dissertação de Mestrado em Ciências da Religião, PUC-SP, 2007.

7 PUNTEL, Joana. A Revista Família Cristã e as Classes Subalternas. Dissertação de Mestrado em Comunicação Social, Universidade Metodista de São Paulo, 1986.

${ }^{8}$ DALMOLIN, Aline Roes. O Discurso sobre Aborto em Revistas Católicas Brasileiras: Rainha e Família Cristã (1980-1990). Tese de Doutorado em Comunicação, Unisinos, São Leopoldo, 2012.

${ }^{9}$ DIDONÉ, Iraci Maria. Cadernos das CEBs: Espaço de Participação? Estudo das Publicações de Edições Paulinas de Autoria e Uso das CEBs. Dissertação de Mestrado em Comunicação, Universidade de São Paulo, 1989. Note-se que tanto os trabalhos de Didoné quanto os de Nascimento e Puntel preocupam-se com o aspecto "popular" das publicações.

${ }^{10}$ Idem.
} 
Uma exceção a essas pesquisas feitas pelas próprias paulinas é o estudo de Paula Montero $^{11}$, que foi o ponto de partida para a presente dissertação. Além de enumerar algumas outras editoras católicas, a antropóloga buscou compreender a trajetória e o caráter das editoras Vozes e Edições Paulinas, as maiores católicas brasileiras, em sua relação com as transformações vividas pela Igreja ao longo do século XX. Montero acentua as relações próximas entre as irmãs paulinas e a CNBB, por exemplo, o que nos despertou para a necessidade de estudar também esses vínculos. Por outro lado, a pesquisa de Paula Montero tem como foco as instituições e as pessoas que as formam, sem se deter sobre os livros publicados, aspecto que nosso trabalho pretende privilegiar.

Montero também contribuiu para um artigo sobre a trajetória das Edições Paulinas em uma revista da editora ${ }^{12}$. Ali, os autores registram 1978 como um momento-chave para a transformação no catálogo da editora, quando passa a se preocupar com a “conscientização" do povo de Deus e com a formação e educação política ${ }^{13}$. Como afirmamos a partir do levantamento do catálogo realizado, é nesse momento, também, que aumenta o volume de publicações da editora.

Em relação às editoras católicas de forma mais ampla, uma outra visão de conjunto foi propiciada pelo artigo-síntese de Agueda Bittencourt ${ }^{14}$. E, para o mercado editorial brasileiro, a principal referência foi o estudo de fôlego realizado por Laurence

\footnotetext{
${ }^{11}$ MONTERO, Paula. "O Papel das Editoras Católicas na Formação Cultural Brasileira". In: SANCHIS, Pierre (org.). Catolicismo: Modernidade e Tradição. São Paulo, Loyola, 1992; MONTERO, Paula. "Letras Católicas na Sociedade de Massas". In: DELLA CAVA, Ralph. \& MONTERO, Paula. E o Verbo se Faz Imagem: Igreja Católica e os Meios de Comunicação no Brasil, 1962-1989. Petrópolis, Vozes, 1991.

${ }^{12}$ MONTERO, Paula; MACCARI, Natália \& MARIA, Darci Luiz. "Edições Paulinas no Brasil: 60 anos (1931-1991)". O Cooperador Paulino, n. 38, set.-dez. 1991.

${ }^{13}$ Idem.

${ }^{14}$ BITTENCOURT, Agueda Bernardete. "O Livro e o Selo: Editoras Católicas no Brasil". Pro-Posições, vol. 25, n. 1 (73), jan.-abr. 2014, pp. 117-137.
} 
Hallewell ${ }^{15}$. Outro trabalho clássico e fundamental para este trabalho foi o estudo das relações entre a Igreja Católica e a política brasileira realizado por Scott Mainwaring ${ }^{16}$.

Para compreender as Edições Paulinas, é preciso levar em conta que ela se localiza em uma interseção entre o campo editorial e o religioso. Esse aspecto religioso deve ser entendido também pelo capital simbólico que proporciona à editora, isto é, não apenas por suas ligações com a instituição católica, mas por sua própria estratégia editorial, que é, antes de tudo, religiosa. Nesse sentido, toda mediação editorial realizada por esses editores é, também, uma mediação religiosa. As congregações paulinas utilizam de forma recorrente o termo "carisma", no sentido de dom divino, para se referir a seu trabalho com os meios de comunicação. Bourdieu, comentando o conceito de carisma de Weber, afirmou que

[...] talvez seja preciso reservar o nome carisma para designar as propriedades simbólicas (em primeiro lugar, a eficácia simbólica) que se agregam aos agentes religiosos na medida em que aderem à ideologia do carisma, isto é, o poder simbólico que lhes confere o fato de acreditarem em seu próprio poder simbólico ${ }^{17}$.

Embora as congregações paulinas não correspondam à figura weberiana do profeta, do religioso carismático, é possível compreender seu "carisma da comunicação" nesse sentido, do carisma que Bourdieu considera como "ideologia profissional", que “conserva a fé do profeta em sua própria 'missão' e ao mesmo tempo lhe fornece os princípios de sua ética profissional"18. Essa ética profissional é um dos elementos de permanência da editora que lhe fornecem capital simbólico suficiente para que ela possa, vez por outra, empreender projetos mais ousados, inclusive no aspecto político.

\footnotetext{
${ }^{15}$ HALLEWELL, Laurence. O Livro no Brasil: Sua História. São Paulo, Edusp, 2012.

${ }^{16}$ MAINWARING, Scott. A Igreja Católica e a Política no Brasil (1916-1985). São Paulo, Brasiliense, 2004.

${ }^{17}$ BOURDIEU, Pierre. "Gênese e Estrutura do Campo Religioso". In: A Economia das Trocas Simbólicas. Introdução, organização e seleção de Sergio Miceli. São Paulo, Perspectiva, 2015, p. 55.

${ }^{18}$ Idem, ibidem.
} 
No caso das Edições Paulinas, esse capital simbólico foi acumulado ${ }^{19}$, conforme veremos no Capítulo 1, ao mesmo tempo que seu capital econômico. Ao longo do século XX a editora cresceu, tornou-se uma empresa lucrativa, chegando, na década de 1980, a formar uma das maiores editoras brasileiras. Mas o elemento econômico mantinha-se atrelado a um objetivo religioso. Assim como alguns editam por convicção política ${ }^{20}$, as Edições Paulinas o faziam por convicção religiosa. Mesmo ao publicar livros de intervenção política ou social direta, estes sempre possuíam um caráter católico. Inserirse na indústria do livro, assim, apresentava-se desde o início como fundamental a seus fins religiosos. Para que estes pudessem ser levados adiante, deveriam andar lado a lado com o crescimento empresarial. O incremento econômico, portanto, não se distinguia, nesse sentido, do religioso.

Para Umberto Eco, por exemplo, a produção editorial teria se tornado um "fato industrial, submetido a todas as regras da produção e do consumo" ${ }^{21}$ muito recentemente. Mas os historiadores do livro veem em seu objeto um caráter de mercadoria muito anterior à indústria cultural contemporânea, e mesmo à própria indústria como modo de produção $^{22}$. Em nossa perspectiva, no mundo do livro, os fins culturais e econômicos são, quase sempre, interdependentes.

Essa interdependência e o incremento mútuo entre os elementos econômico e cultural se fazem muito claros no caso das Edições Paulinas. Para imprimir um livro, era preciso contar com uma estrutura editorial e gráfica. Para que ele pudesse efetivar seus

\footnotetext{
19 Assim como o capital financeiro, o capital simbólico, cultural, social etc. também implica uma “acumulação inicial”. Cf. BOURDIEU, Pierre. As Regras da Arte. Gênese e Estrutura do Campo Literário. São Paulo, Companhia das Letras, 1996, p. 301.

20 Tais como as editoras estudadas em MAUÉS, Flamarion. Livros Contra a Ditadura: Editoras de Oposição no Brasil, 1974-1984. São Paulo, Publisher Brasil, 2013.

${ }^{21}$ ECO, Umberto. Apocalípticos e Integrados. São Paulo, Perspectiva, 1979, p. 50.

${ }^{22}$ Este aspecto foi demonstrado tanto por Febvre \& Martin, para o surgimento da imprensa no início da era moderna, como por Luciano Canfora, ao abordar os livreiros da antiguidade clássica (FEBVRE, Lucien \& MARTIN, Henri-Jean. O Aparecimento do Livro. São Paulo, Edusp, 2017; CANFORA, Luciano. A Biblioteca Desaparecida. Histórias da Biblioteca de Alexandria. São Paulo, Companhia das Letras, 1989).
} 
objetivos religiosos, era preciso que vendesse bem. E, para isso, era preciso que as livrarias se multiplicassem. Assim, ao mesmo tempo que mantêm seus objetivos religiosos, o próprio crescimento econômico necessariamente se torna, também, um fim. O econômico e o cultural se apresentam, portanto, como indissociáveis.

Por isso, o Capítulo 1 retroage no recorte cronológico principal da pesquisa para buscar na formação das Edições Paulinas seus elementos de permanência (religioso) e de mudança: a editora muda com o país, que, em um novo momento histórico, demanda outras respostas. A partir do Concílio Vaticano II, a "boa imprensa", que é moralista e combate a modernidade, não serve mais aos objetivos nem da empresa nem da própria Igreja. Se desde o início as congregações paulinas pretendiam comunicar-se com as massas, a partir de então precisarão de outras chaves para atender seus objetivos. E é a permanência do elemento religioso que possibilita essa mudança.

O Capítulo 2 se inicia com as reformas empreendidas pelo Concílio Vaticano II a partir de 1962, fundamentais para compreender todos os aspectos do catolicismo desde então. Por conta de nosso objeto, privilegiamos as transformações empreendidas quanto à comunicação da Igreja Católica, que, nesse momento, passa por um esforço de sistematização. O que ocorre também no Brasil, no nível episcopal. Por isso, a segunda seção aborda a Conferência Nacional dos Bispos do Brasil, CNBB, instituição que, principalmente por seus canais de comunicação, exerceu um papel importante na política brasileira, em especial como oposição à ditadura militar. Um dos canais encontrados foi justamente a parceria com as Edições Paulinas, que, nesse momento, já possuíam uma ampla estrutura de produção e venda de impressos.

Se esse capítulo aborda as relações da editora com a estrutura eclesiástica, o Capítulo 3, em sua primeira parte, busca situá-la no mercado editorial no período 19621994. Os elementos apresentados no Capítulo 1 são importantes para compreender como, 
no período de uma das maiores crises econômicas do país, na década de 1980, as Edições

Paulinas se tornaram uma das principais editoras nacionais. Já na segunda parte do Capítulo 3, apresentaremos algumas das práticas e estratégias editoriais da empresa, em relação com as obras de maior sucesso do catálogo.

Esses três primeiros capítulos fornecem condições para que, no Capítulo 4, façamos um estudo de caso sobre as coleções de maior teor político da editora, em uma chave de esquerda, publicadas a partir de 1978. Na primeira seção, abordaremos as coleções a respeito da Teologia da Libertação e das comunidades eclesiais de base, que, juntas, formavam a teoria e a prática mais progressistas ocorridas na Igreja Católica brasileira e, mesmo, latino-americana (como veremos, muitas dessas obras são traduzidas do espanhol). Essas publicações objetivavam, sobretudo, formar o chamado "agente de pastoral" dentro de um projeto que, embora não fosse homogêneo, possuía diversos elementos de coesão. Na segunda seção do capítulo, abordaremos a Edição Pastoral da Bíblia, lançada em 1990, e todo o projeto editorial (outras coleções) que a acompanha. A nosso ver, essa Bíblia representa o fim de um ciclo para a Igreja progressista brasileira, já que, nos anos 1990 por diversos fatores que se alinham, entre eles a oposição de João Paulo II à Teologia da Libertação, o crescimento das igrejas protestantes neopentecostais e a própria redemocratização, que tira a Igreja do centro do debate público - esse projeto se arrefece.

Entre 1993 e 1994²3, inicia-se a separação das Edições Paulinas em duas novas marcas. Essa reforma na empresa coincide com as transformações na Igreja, o que faz com que as novas marcas também reformem seus catálogos e dediquem cada vez menos espaço às questões políticas e sociais. Assim, encerramos o recorte desta pesquisa.

\footnotetext{
${ }^{23}$ Alguns livros são lançados já em 1993 com a marca Paulus; mas, continua-se publicando também como Edições Paulinas ainda em 1994. A livraria das Edições Paulinas na Praça da Sé, em São Paulo, muda de nome para Paulus apenas em 1995 (cf. O Estado de S. Paulo, 8.3.1995, p. Z12). Como o processo de mudança se estende entre 1993 e 1995, decidimos adotar o marco de 1994, quando saem as últimas publicações sob a marca Edições Paulinas.
} 


\title{
Capítulo 1
}

\section{Formação das Edições Paulinas}

\author{
È incredibile la quantità di opuscoli, riviste, \\ foglietti, corrieri parrocchiali che circolano \\ dappertutto, che cercano infiltrarsi anche \\ nelle famiglie piú refrattarie, e che si \\ occupano di tante altre cose oltre la \\ religione.
}

Antonio Gramsci, "La Buona Stampa"24

\subsection{Origens: "Difundir a Boa Imprensa e Combater a Má"}

Em agosto de 1914, pouco antes da entrada da Itália na Primeira Guerra, o sacerdote Tiago Alberione ${ }^{25}$ comprou e assumiu as dívidas da Gazzetta d'Alba, pequeno jornal católico até então administrado pela Associação da Boa Imprensa, na região do Piemonte. A aquisição se restringia ao direito de publicá-la, pois o jornal não possuía tipografia e dependia das instalações e do maquinário de um terceiro, com quem o contrato venceria em breve. A fim de expandir sua atuação editorial para além do periódico, o padre constituiria sua própria tipografia ${ }^{26}$.

\footnotetext{
24 “É inacreditável a quantidade de opúsculos, revistas, folhetos, correios paroquiais que circulam por toda parte, que buscam infiltrar-se até mesmo nas famílias mais refratárias e que se ocupam de tantas outras coisas além da religião" (Avanti!, 16 fev. 1916 apud PIVATO, Stefano. "L'Organizzazione Cattolica della Cultura di Massa Durante il Fascismo". Italia Contemporanea, vol. 30, n. 132, 1978, p. 6).

${ }^{25}$ Batizado Giacomo Alberione, seu prenome seria traduzido para os idiomas dos locais em que as congregações paulinas mais tarde se instalaram. No Brasil e em Portugal, adotou-se Tiago, grafia já consagrada e presente inclusive em logradouros públicos e que, portanto, será a utilizada neste trabalho. Remetendo à raiz hebraica comum com Giacomo, da mesma forma como se costuma traduzir o Tiago bíblico, em espanhol Alberione passou então a ser conhecido por Santiago, em francês, por Jacques, em inglês, por James e, em alemão, por Jakob.

${ }^{26}$ ROLFO, Luís. Padre Alberione. Anotações para uma Biografia. $2^{a}$ ed. São Paulo, Paulus, 2001, pp. 7879.
} 
Assim, foi criada em Alba a Escola Tipográfica, que recrutava jovens aprendizes para o trabalho de composição e impressão. Em breve, a Escola se tornaria sede de um projeto mais amplo, a Unione Cooperatori Buona Stampa, ou União dos Colaboradores da Boa Imprensa. De 1918 a 1932, a União publica um boletim a cada dois meses, nas capas dos quais seu "Estatuto" determina sua finalidade - "promover a boa imprensa" e seus meios - "orações, ofertas e obras (escrever, difundir a boa imprensa e combater a má) ${ }^{\text {27 }}$. Ao pé da página, reproduzia-se a autorização ao funcionamento da União lavrada pelo bispo de Alba, que assim a justificava: "tendo conta da urgência de favorecer a boa imprensa, aprovamos a união proposta, esperando que ela encontre nesta diocese muitos aderentes" 28 .

Iniciativas como as de Alberione pululavam pela Itália. A intenção de combater a imprensa cattiva, má, e difundir a buona, boa, nesses termos, remetia pelo menos a Leão $\mathrm{XIII}^{29}$, mas é com Bento XV que ela ganha caráter sistemático: percebendo a necessidade de organizar o combate cultural católico, ele cria em 1915 a Opera Nazionale per la Buona Stampa. À Opera é dedicado um artigo da Civiltà Cattolica de 1918, que afirma: "Cabe agora aos católicos multiplicar sua eficácia, difundindo [os trabalhos da Opera Nazionale per la Buona Stampa] amplamente, para que a instituição aumente, a fim de poder dar à luz outros opuscoli e aumentar os meios de propagação das boas publicações"30.

A Igreja considerava necessário se organizar para liderar as novas massas urbanas e combater a "má" e prolífica imprensa popular, como a socialista ${ }^{31}$. Para alguns, como

\footnotetext{
${ }^{27}$ Unione Cooperatori Buona Stampa, Anno III, n. 7, settembre 1920, p. 1. O boletim foi publicado entre 1918 e 1932, passando a se chamar Unione Cooperatori Apostolato Stampa a partir de 1929. Os fac-símiles dos volumes de 1918 a 1921 estão disponíveis em http://operaomnia.alberione.org/. Acesso em 17.4.2019. Grifos do original.

${ }^{28}$ Idem, ibidem.

${ }^{29}$ KLAUCK, Samuel. "A Imprensa como Instrumento de Defesa da Igreja Católica e de Reordenamento dos Católicos no Século XIX”. Mneme - Revista de Humanidades, n. 11, vol. 29, pp. 132-148, jan.-jul. 2011. 30 "Rivista della Stampa". La Civiltà Cattolica, anno 69, vol. II, 1918, p. 458.

${ }^{31}$ PIVATO, Stefano. "L'Organizzazione Cattolica della Cultura di Massa Durante il Fascismo", op. cit., pp. 4-5.
} 
Alberione, também se mostrava necessário lutar contra a maçonaria ${ }^{32}$. A cultura católica era cada vez menos um sinônimo de cultura nacional, e a sensação de inadequação daquela à modernidade exigia novas formas de ação ${ }^{33}$.

O que os religiosos consideravam uma "má" imprensa não se restringia aos periódicos revolucionários, fossem socialistas ou anarquistas. Outra grande inimiga era a própria literatura de ficção popular, impressa em escala industrial e vendida a preços acessíveis, em especial os livros que atentavam contra os moldes de comportamento considerados adequados pelos católicos, romances sentimentais, "escandalosos"34.

Isabelle Olivero, ao estudar a edição francesa em fins do século XIX, afirmou que os católicos que buscavam divulgar "bons livros" perceberam ser mais eficiente publicar coleções com preços e formatos similares aos das populares, leigas, para combatê-las com "leituras edificantes" em seu próprio terreno - para a autora, esses livros seriam tidos como uma espécie de antídoto (contrepoison) a seus equivalentes não católicos ${ }^{35}$. A partir do século XVIII, nas palavras de Marisa Lajolo e Regina Zilberman, “condenam-se gêneros e preferências, por produzirem efeitos supostamente deletérios; e acusa-se de

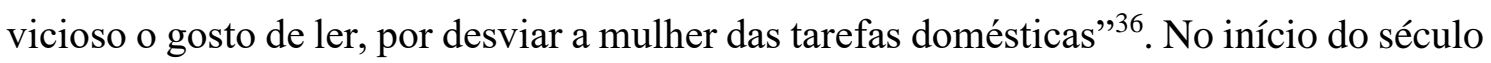
XX, a condenação se mantém, mas a leitura, sobretudo de romances, já era irrefreável.

\footnotetext{
${ }^{32}$ ALBERIONE, Tiago. Abundantes Divitiae Gratiae Suae. História Carismática da Família Paulina. São Paulo, Paulus, 2000, pp. 43, 48. O título do livro, escrito por Alberione em 1953, refere-se a uma passagem da carta aos Efésios, atribuída a Paulo: "a extraordinária riqueza da sua graça" (Efésios 2:7. As citações bíblicas deste trabalho foram extraídas de BÍBLIA de Jerusalém. Nova Edição Revista e Ampliada. São Paulo, Paulus, 2002).

${ }^{33}$ TRANIELLO, Francesco. "L'Editoria Cattolica tra Libri e Reviste". In: TURI, Gabriele (org.). Storia dell'Editoria nell'Italia Contemporanea. Florença, Giunzi, 1997, p. 313.

${ }^{34}$ Inúmeros religiosos do início do século XX tentaram evitar que os católicos tivessem contato com a má imprensa organizando compêndios com classificações de autores e livros, em especial romances, separando-os entre aqueles que podiam e não podiam ser lidos. No Brasil, o frade franciscano Pedro Sinzig organizou o guia Através dos Romances: Guia para as Consciências (Petrópolis, Vozes de Petrópolis, 1915. 2. ed. 1923). Na França, tentativa semelhante fora feita pelo cônego Louis Bethléem em 1904, com a publicação de Romans à Lire et Romans à Proscrire, que teve enorme sucesso, com dez reedições entre 1905 e 1932.

${ }^{35}$ OLIVERO, Isabelle. L'Invention de la Collection. Paris, Éditions de l'Imec/Maison des Sciences de l'Homme, 1999, pp. 186-187.

${ }^{36}$ LAJOLO, Marisa \& ZILBERMAN, Regina. "Inventando a Leitora". In: A Formação da Leitura no Brasil. São Paulo, Ática, 1996.
} 
Portanto, busca-se oferecer substitutos moralmente adequados. Mais tarde, em seu $O$ Apostolado da Edição, de 1944, Alberione recomendaria aos paulinos a edição de "leituras amenas": atribuindo a Leão XIII a ideia de que às armas era necessário opor-se com armas, conclui que aos romances era preciso opor romances ${ }^{37}$.

As edições da boa imprensa podiam compreender, então, romances moralistas, materiais devocionais, pedagógicos, pequenos catecismos, periódicos ilustrados, almanaques... Ou seja, não apenas livros religiosos, mas publicações populares que difundiam uma perspectiva católica e conservadora sobre diversos aspectos da vida, em especial o familiar. A tipografia de Alba estava inserida nessa lógica. Nos anúncios de um boletim de 1919, constam alguns dos livros de edição própria: La Donna Associata allo Zelo Sacerdotale ("um guia muito útil no cuidado moral das filhas, mães, esposas", sobre como as mulheres, leigas e religiosas, podem colaborar com o trabalho dos sacerdotes, homens), Il Piccolo Catechismo della Dotrina Cristiana (em três níveis, "o mais fácil para as crianças menores e o mais difícil para as maiores”), I Doveri delle Spose e delle Madri... ${ }^{38}$

As mulheres também seriam incorporadas à União dos Cooperadores da Boa Imprensa, mas de forma diferente que os rapazes. De início, em 1916, trabalham em uma oficina de costura pertencente à tipografia - a guerra aparecia como uma oportunidade para arrecadar fundos confeccionando uniformes para os soldados ${ }^{39}$. Elas passam a se envolver com os impressos quando saem para vender "bons livros" nas portas das igrejas aos domingos ${ }^{40}$. Somente em 1918, quando a pequena comunidade feminina de Alba se transfere para Susa, outra cidade da região, elas começam a compor e imprimir o jornal

\footnotetext{
${ }^{37}$ ALBERIONE, Santiago. El Apostolado de la Edición. Manual Directivo de Formación y de Apostolado. [s. 1.], San Pablo, 1998, p. 252.

${ }^{38}$ Unione Cooperatori Buona Stampa. Anno II, n. 7, 1919, pp. 7-8.

${ }^{39}$ MARTINI, Catarina A. As Filhas de São Paulo: Anotações para uma História (1915-1984). São Paulo, Paulinas, 1995, p. 124.

${ }^{40}$ Idem, p. 132.
} 
da diocese. Na Seção Feminina da Escola Tipográfica, trabalhavam jovens a partir de doze $\operatorname{anos}^{41}$. Mas também em Alba, onde permaneceram os homens, logo chegam novas moças, que ficam praticamente restritas a trabalhos domésticos em benefício dos membros da "ala masculina"42. Em 1923, a tipografia de Susa é fechada e, no retorno a Alba, elas se responsabilizam definitivamente pelas vendas e assinaturas. Porém, voltariam a editar apenas após $1931^{43}$ - ainda que não seja possível ter certeza se realmente não trabalhavam na tipografia nesse meio tempo, sem receber os créditos oficiais, já que era necessário provar à Igreja, em respeito aos bons costumes, que os homens e mulheres daquela instituição não só viviam como também trabalhavam separadamente. Separação que se mantém na empresa de forma definitiva.

O fato é que entre a criação da Escola e seu reconhecimento oficial como congregação religiosa, a situação dessas pessoas, homens e mulheres, é um pouco incerta. Em 1921, a Escola Tipográfica passa a se chamar Pia Società San Paolo, Pia Sociedade de São Paulo, e catorze rapazes "emitem votos perpétuos", isto é, tornam-se oficialmente religiosos. Continuando os estudos, poderiam ser ordenados sacerdotes, caminho que a maioria seguiria. Um ano depois, é a vez da definição institucional das mulheres, quando é criada a Pia Società Figlie di San Paolo, a Pia Sociedade Filhas de São Paulo ${ }^{44}$. As primeiras aprovações eclesiásticas para as congregações só seriam expedidas em 1927 e 1928, respectivamente ${ }^{45}$. Assim, passam a ser conhecidos como paulinos e paulinas.

\footnotetext{
${ }^{41}$ Unione Cooperatori Buona Stampa. Anno III, n. 6, 1920, p. 6. A prática era comum. Da Polônia, Rosa Luxemburgo criticara a situação em 1905: "[A Igreja] procurou rapidamente se beneficiar dessa miséria na qual caiu o povo simples, para pôr essa mão de obra barata a trabalhar para ela e para o seu enriquecimento. Os conventos tornaram-se cavernas da exploração capitalista - e da forma mais horrorosa, pois exploravam o trabalho de mulheres e crianças" (LUXEMBURGO, Rosa. “A Igreja e o Socialismo" [1905]. Textos Escolhidos, vol. 1 (1899-1914). Organização de Isabel Loureiro. São Paulo, Unesp, 2018, p. 198).

${ }^{42}$ MARTINI, Catarina A. As Filhas de São Paulo, op. cit., pp. 161-163.

${ }^{43}$ Idem, p. 248.

${ }^{44}$ Idem, pp. 165-169.

45 As primeiras são as aprovações diocesanas, que tornam os institutos sujeitos ao bispo de Alba. A aprovação direta da Santa Sé, transformando-as em congregações de direito pontifício, subordinadas diretamente ao papa, só viria em 1949 para a masculina e em 1953 para a feminina (Idem, p. 415).
} 
Enquanto Alberione mantém-se como superior geral dos paulinos, a irmã paulina Teresa Merlo, conhecida como $\mathrm{Tecla}^{46}$, torna-se superiora geral da congregação feminina. Na prática, Alberione exerceria liderança sobre os dois grupos até sua morte, em 1971.

Mesmo após terem se tornado reconhecidamente congregações religiosas católicas, elas seguiriam muito diferentes dos grupos mais tradicionais, como a Companhia de Jesus. A entrada de jovens nas congregações paulinas continuava ocorrendo da mesma forma, como aprendizes de tipógrafos, impressores e livreiros. Portanto, ainda que houvesse também uma formação religiosa e intelectual, o trabalho, sobretudo dos mais jovens e não ordenados e, ainda mais, das mulheres, era primordialmente operário. Seus membros, portanto, não provinham das elites - o que sugere que as motivações para o ingresso na instituição deveriam ser, em um primeiro momento, materiais.

A imprensa católica se fortaleceria com a ascensão do fascismo. Em 1936, é realizada em Roma a Exposição Universal da Imprensa Católica, da qual os editores paulinos participam, e onde Alberione chega a celebrar uma missa ${ }^{47}$. A Exposição recebeu uma visita oficial do primeiro Ministro da Imprensa e Propaganda de Mussolini, Dino Alfieri, que foi filmada pelo Instituto Luce, empresa cinematográfica ligada ao fascismo $^{48}$. Stefano Pivato afirma que a buona stampa exercia uma função "integradora" e reforçava a ideia de uma sociedade estável, isenta de conflitos sociais ${ }^{49}$. Portanto, bem quista pelo governo italiano.

\footnotetext{
46 Tecla Merlo nascera em Castagnito, comuna próxima a Alba, e foi uma das primeiras a ingressar na congregação, o que demonstra que, de início, a composição dos membros era, sobretudo, de origem local. ${ }^{47}$ COLACRAI, Angelo. "Presentación”. In: ALBERIONE, Santiago. El Apostolado de la Edición. Manual Directivo de Formación y de Apostolado, op. Cit., p. 28.

${ }^{48}$ Os filmes estão disponíveis em https://www.archivioluce.com/ Acesso em 11.12.2020.

${ }^{49}$ PIVATO, Stefano. "L’Organizzazione Cattolica della Cultura di Massa Durante il Fascismo", op. cit., p. 11.
} 
Nessa mesma década de 1930, Antonio Gramsci, que seguia acompanhando as atividades da Igreja Católica, em especial pela imprensa, enquanto esteve preso, escreveu a respeito da Pia Sociedade de São Paulo:

A coleção "Tolle e lege" da Ed. "Pia Società S. Paolo", Alba Roma, num elenco que inclui 111 títulos, em 1928, registra 65 romances de Ugo Mioni, que certamente não são todos os publicados pelo prolífico monsenhor, o qual, de resto, não escreveu apenas romances de aventuras, mas também de apologia, de sociologia e também um volumoso tratado de "ciência das missões". Editoras católicas para publicações populares: existe também uma publicação periódica de romances. Mal impressos e em traduções incorretas ${ }^{50}$.

Trata-se da coleção Tolle et Lege ${ }^{51}$, que publicava romances moralistas. O autor dos volumes, Ugo Mioni - cuja autoria é atribuída a mais de quatrocentos livros colaborou com Alberione escrevendo e intercedendo junto a Roma pela aprovação da Pia Sociedade de São Paulo, da qual chegou a fazer parte, tornando-se mais tarde dominicano ${ }^{52}$.

A menção à editora dos paulinos nos Cadernos do Cárcere de Gramsci e a participação em eventos com suporte da Igreja e do governo demonstram que aumentavam as proporções da "boa imprensa" católica, inclusive do projeto de Alberione. As vendas cresciam, as congregações e a empresa também. Entre 1928 e 1930, treze livrarias paulinas seriam abertas por toda a península, e desde 1926 já havia uma casa no centro do mundo católico: Roma ${ }^{53}$. O momento era, como um todo, favorável aos livros católicos: além dos incentivos à chamada boa imprensa, 1926 foi o ano de fundação da

\footnotetext{
${ }^{50}$ GRAMSCI, Antonio. “Caderno 21 (1934-1935)”. In: Cadernos do Cárcere, vol. 6: Literatura. Folclore. Gramática. Edição, Organização e Tradução de Carlos Nelson Coutinho, Luiz Sérgio Henriques e Marco Aurélio Nogueira. Rio de Janeiro, Civilização Brasileira, 2002, p. 26.

${ }^{51}$ O título remete a uma passagem das Confissões de Agostinho: "pegue e leia".

${ }^{52}$ MARTINI, Catarina A. As Filhas de São Paulo, op. cit., p. 168, nota 199.

${ }^{53}$ ROLFO, Luís. Padre Alberione, op. cit., p. 272.
} 
Libreria Editrice Vaticana, editora da Santa Sé; e data de 1929 o Tratado de Latrão, concordata entre Pio XI e Mussolini que criou o Estado do Vaticano.

Desde a escolha do patrono das congregações - São Paulo, na tradição cristã, o missionário por excelência ${ }^{54}$-, já era clara a intenção de Alberione de expandir sua atividade editorial para além da Itália. Os variados apoios, o reconhecimento eclesiástico, a experiência adquirida e, principalmente, a boa situação financeira permitiriam aos paulinos, inclusive, atravessar o Atlântico.

Os padres paulinos italianos Xavier Boano e Sebastião Trosso foram enviados por Alberione à cidade de São Paulo, em agosto de 1931. Nos próximos meses, paulinos se instalariam também em Buenos Aires e Nova York. As três metrópoles formaram, entre o fim do século XIX e início do XX, os principais centros de imigração italiana nas Américas ${ }^{55}$.

Segundo as memórias de Boano, após intermediações de religiosos locais, ele e Trosso foram recebidos pelo arcebispo D. Duarte Leopoldo e Silva, que, como condição para sua permanência em São Paulo, exigiu que assumissem as paróquias de Santana e Tremembé ${ }^{56}$. Ainda que a congregação formasse sacerdotes, sua expansão não tinha como objetivo fornecer párocos às Américas, mas sim levar adiante o trabalho da "boa imprensa". Porém, a escassez de clérigos impedia que a Igreja paulista se desse ao luxo de desperdiçá-los.

\footnotetext{
${ }^{54} \mathrm{~A}$ missão, aqui, é entendida como incumbência e como viagem, ambas com objetivo de evangelização. Sobre o primeiro sentido, mais próximo ao do carisma, da vocação, Alberione afirma: "Cada um entenda e pense que é transmissor de luz, alto-falante de Jesus, secretário dos evangelistas, de São Paulo, de São Pedro...; que tanto a caneta da mão como o tinteiro da máquina impressora desempenham uma única missão" (ALBERIONE, Tiago. Abundantes Divitiae Gratiae Suae. História Carismática da Família Paulina, op. cit., p. 75) e, sobre o segundo: "Brota do espírito católico e do mandato divino: 'Ide, pregai a todas as nações'; é infundido na crisma; cresce na ordenação. São Paulo é o grande caminheiro" (Idem, p. $64)$.

${ }^{55}$ Para dados, ver KLEIN, Herbert S. "A Integração dos Imigrantes Italianos no Brasil, na Argentina e Estados Unidos”. Novos Estudos Cebrap, n. 25, pp. 95-117, out. 1989.

${ }^{56}$ MARIN, Darci L. "50 Anos Depois: Entrevista com P. Boano". O Cooperador Paulino. Ano 48, n. 1, 1981, p. 26.
} 
De acordo com Dilermando Vieira, a criação de novas dioceses no Brasil, no início do século XX, obrigara os bispos a "realizarem verdadeira peregrinação pela Europa, à procura de ordens e congregações dispostas a auxiliá-los”. Segundo o autor, as "novas ordens" recém-fundadas na Europa e chegadas ao Brasil eram vistas com melhores olhos pelos bispos (inclusive pelo de São Paulo) que as "antigas ordens brasileiras", como a beneditina, carmelita ou franciscana, que estariam "acostumadas à licenciosidade" ${ }^{57}$. Não surpreende, portanto, a rápida integração dos padres paulinos.

O incentivo da Pia Sociedade de São Paulo para que seus membros fossem ordenados pode ser compreendido nesse sentido. Além do status ostentado pelo título os livros são, ainda hoje, preferencialmente assinados com "padre" antes do nome do autor -, a autorização para rezar missas facilitou a inserção da congregação nas diversas cidades e países em que se instalou. O serviço paroquial era sempre mais imediato e garantido do que abstratas intenções editoriais. Contudo, essas eram, na realidade, bastante concretas: os recém-chegados traziam certo capital, pois naquele mesmo ano adquiriram uma tipografia.

Tratava-se das instalações do semanário La Squilla ${ }^{58}$, editado por capuchinhos desde 1905, na Avenida Brigadeiro Luís Antônio, próximo à Praça da Sé. Redigido em sua maior parte em italiano, o jornal era destinado à comunidade imigrante e tinha como subtítulo Settimanale per il Popolo. Dio - Patria - Famiglia (Semanário para o Povo. Deus - Pátria - Família). O lema já era, portanto, um mote comum à direita, ainda antes da articulação do integralismo ou mesmo do fascismo. Angelo Trento, que teve acesso a

\footnotetext{
${ }^{57}$ VIEIRA, Dilermando Ramos. O Processo de Reforma e Reorganização da Igreja no Brasil (1844-1926). Aparecida, Santuário, 2007, pp. 447-456.

58 "A Campainha". Título de jornal recorrente na Itália.
} 
exemplares dos anos 1920, considera o jornal como integralista ${ }^{59}$. Mais tarde, já sob a direção dos paulinos, torna-se La Squilla: Settimanale Cattolico (Semanário Católico).

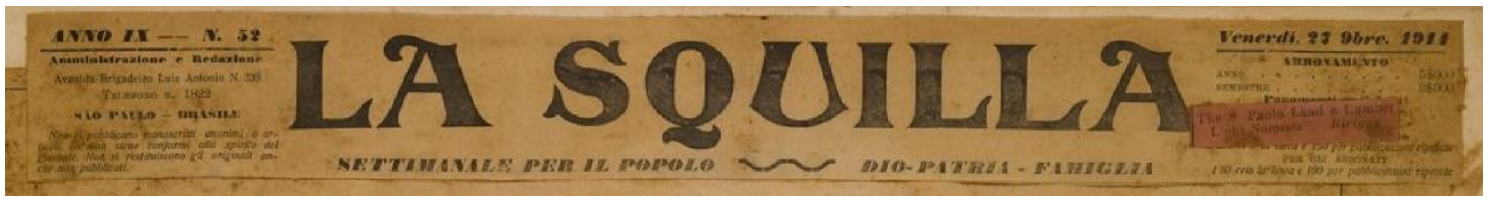

Figura 1: Cabeçalho do La Squilla, n. 37, 29.11.1911. SOARES, Fernando José Clark Xavier. Roberto Clark: Meu Avô. São Paulo, F. J. C. X. Soares, 2003.

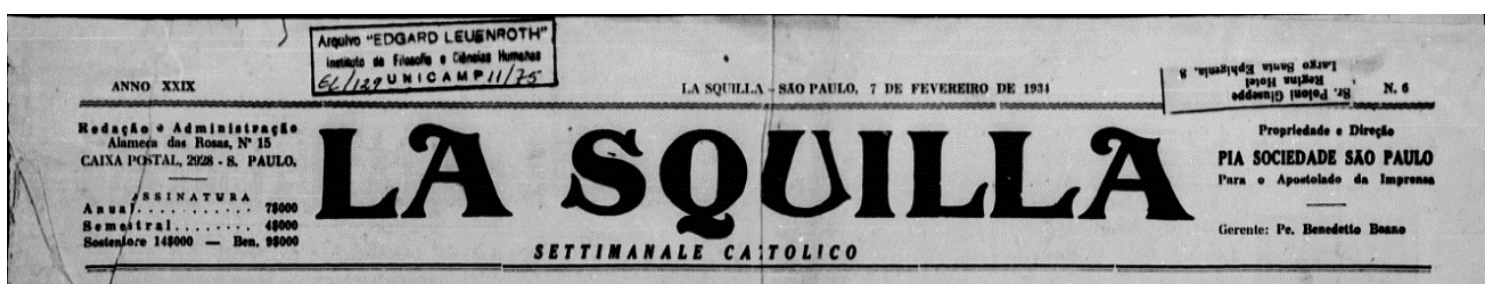

Figura 2: Cabeçalho do La Squilla, n. 6, 7.2.1934. Exemplar pertencente ao Arquivo Edgard Leuenroth (AEL)/Unicamp.

O único exemplar completo encontrado data de 1934, pertencera a um assinante de nome Giuseppe Poloni, foi guardado por Edgard Leuenroth e está disponível no arquivo que leva seu nome, na Unicamp ${ }^{60}$. Por ele, nota-se que as tendências fascistas do

\footnotetext{
${ }^{59}$ TRENTO, Angelo. Do Outro Lado do Atlântico: Um Século de Imigração Italiana no Brasil. São Paulo, Nobel, 1989, pp. 188, 496.

${ }^{60}$ Edgard Leuenroth (1881-1968), jornalista e tipógrafo anarquista e anticlerical, acompanhava de perto as atividades dos católicos (como fazia Gramsci na Itália). Um artigo publicado no A Lanterna: Jornal de Combate ao Clericalismo, dirigido por Leuenroth, criticava os paulinos já em 1935. Assinado por José Gavronski, o texto ironizava a campanha de arrecadação dos paulinos, que prometia àqueles que contribuíssem com dez mil réis ao "apostolado da boa imprensa" as bênçãos de "duas mil missas" que por eles seriam rezadas (A Lanterna: Jornal de Combate ao Clericalismo, São Paulo, n. 396, 1.6.1935, p. 2). Além disso, Leuenroth já havia se envolvido em uma polêmica com os antigos editores capuchinhos do $L a$ Squilla em 1910 (VIEIRA, Dilermando Ramos. O Processo de Reforma e Reorganização da Igreja no Brasil (1844-1926), pp. 457-458). Os dois casos - a conservação do La Squilla por Leuenroth e o comentário a respeito dos paulinos no jornal - demonstram que, então há poucos anos no Brasil, a congregação já ocupava certo espaço no debate público.
} 
jornal se mantinham nos anos 1930, mesmo com as alterações dos diretores e de seu título.

Na quarta e última página, conta-se, em português, uma anedota moral:

Itália - Pai exemplar - O filho mais novo de Mussolini, foi reprovado no exame, e teve de repetir o ano. Mussolini, em vez de prevalecer-se do seu cargo para proteger o filho, louvou a professora, e recomendoulhe que trate o seu filho como a qualquer outro menino vadio ${ }^{61}$.

Logo depois, em italiano, um texto comenta a reforma financeira empreendida por Mussolini, “apenas possível quando um país tem uma economia saudável e um governo forte que conquistaram a confiança pública"62. Na mesma página, afirma-se que na Alemanha ocorrera um "Fato histórico. A proclamação do Império Unitário. [...] Um bloco compacto e firme nas mãos de homens fortes, decididos a dar-lhe potência" ${ }^{63}$. O autor do texto ainda afirmava que Hitler possuía "boa vontade" em escutar o Papa e desistir da "bárbara lei de esterilização" nazista ${ }^{64}$. A linha editorial, portanto, não se modificara sob os paulinos, que, como comentado na seção anterior, mantinham boas relações com o governo italiano. Stefano Pivato sublinhou o papel que as congregações católicas, por meio da imprensa, exerceram na propaganda favorável ao fascismo fora da Itália ${ }^{65}$.

A Igreja Católica no Brasil, como um todo, também vivia um momento particularmente reacionário. Diversos setores e quadros se alinharam ao integralismo, fosse oficialmente, como Alceu Amoroso Lima (então secretário-geral da Liga Eleitoral Católica), João Becker (arcebispo de Porto Alegre) e Helder Câmara (à época padre no Ceará), fosse demonstrando estima, como fez Duarte Leopoldo e Silva (arcebispo de São

\footnotetext{
${ }^{61}$ La Squilla. Settimanale Cattolico, n. 6, 7.2.1934, p. 4.

${ }^{62}$ Idem, ibidem.

${ }^{63}$ Idem, ibidem.

${ }^{64}$ Idem, ibidem.

${ }^{65}$ PIVATO, Stefano. "L’Organizzazione Cattolica della Cultura di Massa Durante il Fascismo", op. cit., p. 24.
} 
Paulo até 1938) ${ }^{66}$. A própria Rerum Novarum de Leão XIII (publicada em 1891), ao criticar o comunismo, o liberalismo e o que considerava "materialismo", era utilizada como respaldo para a extrema direita católica ${ }^{67}$. Considerando as transformações posteriores nas Edições Paulinas, é possível que este seja o principal motivo da atual ausência do $L a$ Squilla nos arquivos.

O jornal também servia, é claro, aos fins editoriais da congregação. À semelhança dos boletins publicados na década de 1910 pela Escola Tipográfica de Alba, em 1934 os editores do La Squilla estão fazendo campanha para conseguir financiadores, divulgadores e vendedores. Nesse momento, ainda quase nenhum livro havia sido publicado pela congregação no Brasil. Assim, juntamente com os livros importados da Itália, vendiam livros em português editados por outros grupos, grande parte deles de combate ao espiritismo, crescente nos centros urbanos brasileiros desde meados do século XIX ${ }^{68}$. Para distribuí-los, os paulinos criam os Centros de Difusão, com representantes em pequenas cidades do interior paulista. Essas pessoas, em sua maioria pequenos comerciantes, recebiam $20 \%$ de desconto ao comprar os livros para revender, além de agradecimentos e bênçãos no jornal.

Dessa maneira, o La Squilla funcionou como um meio para o início da elaboração de uma estrutura editorial. A estratégia foi similar à de Alberione quando da compra da Gazzetta d'Alba. Além do jornal já possuir assinantes, anunciantes - no exemplar de 1934 há, inclusive, um anúncio da Casa Bancária Alberto Bonfiglioli \& Co. - e um sistema

\footnotetext{
${ }^{66}$ Cf. GONÇALVES, Leandro Pereira \& CALDEIRA NETO, Odilon. O Fascismo em Camisas Verdes: Do Integralismo ao Neointegralismo. Rio de Janeiro, FGV, 2020, pp. 19-20.

${ }^{67}$ Idem, pp. 18-19.

${ }^{68}$ Os livros anunciados são Os Jesuítas e a Monita (3\$000) [três mil-réis], O Espiritismo (Conferências) (3\$000), O Cristianismo e o Progresso (3\$000), O Perigo Yankee (1\$000), Os Grandes Gênios (2\$500), Espiritismo e Maçonaria (6\$00), Catecismo Anti-Espírita (5\$000), Micelânia Apologética (3\$000), O Espiritismo (Pastoral Coletiva dos Bispos Brasileiros) (1\$000), Cancioneiro da Virgem (5\$000), Que Jesus Ensinou (1\$000), Verdades Católicas (3\$000), Protestantismo e Espiritismo (2\$000), Lágrimas e Sorrisos (3\$000), Só no Mundo (3\$000), Bom-Josias (5\$000) (La Squilla. Settimanale Cattolico. 7.2.1934, p. 3). Havia também uma Bíblia italiana, importada, vendida por um preço muito superior, $20 \$ 000$.
} 
(mesmo que precário) de distribuição, a tipografia do La Squilla também imprimia $\operatorname{livros}^{69}$. Um livro publicado pelos paulinos em 1933 sai com a imprenta "Tipografia de 'La Squilla' ",70. Enquanto a tipografia viabilizou as primeiras produções, a existência de uma rede já estabelecida de leitores se apresentou como uma oportunidade de ganhos financeiros e de difusão do trabalho e do próprio nome da congregação. A propaganda da "boa imprensa" reforçava a necessidade de se comprar "bons livros", dos quais os paulinos pretendiam fazer-se sinônimo.

Pouco depois, o Estado Novo de Getúlio Vargas iniciaria a chamada Campanha de Nacionalização: a exigência de que os jornais saíssem em português e a ameaça contra os que falassem línguas como italiano, japonês e alemão impediria que o La Squilla continuasse a ser publicado. Na virada da década de 1930 para 1940, os paulinos passam a editar um novo periódico, A Imprensa: Semanário Católico Popular, redigido em português, que sobrevive até 1957, com o lema Restaurar Tudo em Cristo. Sua linha editorial seria mais moderada, mas manteria em seus princípios referências positivas a figuras como Mussolini. De início voltado sobretudo a pautas religiosas, na altura dos anos 1950 expande sua temática, passando a reportar, por exemplo, notícias do futebol brasileiro. É digno de nota que, embora o acervo quase completo do A Imprensa esteja conservado na biblioteca da Fapcom, faculdade mantida pelos paulinos em São Paulo ${ }^{71}$, o mesmo não tenha ocorrido com o La Squilla.

Em 1939, o grupo inaugura uma livraria na Praça da Sé, no centro de São Paulo. Uma notícia publicada no jornal Folha da Noite demonstra como a editora vai construindo sua imagem no Brasil, como "genuinamente católica":

\footnotetext{
${ }^{69}$ TAUBATÉ, Modesto Rezende de \& PRIMIERO, Fidelis Motta. Os Missionários Capuchinhos no Brasil. Esboço Histórico. São Paulo, Tipografia do Semanário La Squilla, 1929.

70 ROSARIO, Fray Pedro Corro del. Gonzalo de Berceo. Estudio Critico-Literario. São Paulo, Pia Sociedade de São Paulo/Tipografia de La Squilla, 1933. O livro está em espanhol e o autor é um frade da Ordem dos Agostinianos Recoletos.

${ }^{71}$ A Fapcom, Faculdade Paulus de Comunicação, foi fundada em São Paulo em 2005.
} 
Inaugurou-se hontem em S. Paulo a primeira livraria genuinamente catholica [...] A Pia Sociedade S. Paulo, entidade creada e mantida pelos padres Paulinos e destinada a fomentar a leitura de publicações catholicas [...] inaugurou hontem, cerca das 15 horas e meia, a Livraria São Paulo, depositária de livros cuja leitura é aprovada pela igreja catholica $^{72}$.

A presença no centro da cidade facilitava não apenas a comercialização como, também, o reconhecimento da editora e congregação pelo público - fosse cliente ou apenas passante. Conforme afirma a matéria da Folha da Noite, ali havia apenas livros aprovados pela Igreja - e eram vendidos também objetos e paramentos religiosos, como terços - o que conferia ao espaço uma distinção especial. Conforme veremos, quando da inauguração da loja, já havia em São Paulo uma comunidade de religiosas paulinas, e um de seus primeiros trabalhos foi na livraria - com vestimentas religiosas, isto é, hábito de freira, o que contribuía para a própria caracterização do espaço como católico. Todos esses elementos - a localização ao lado da Catedral da Sé, as mercadorias, o fato do atendimento ser realizado por freiras - contribuíam para tornar a livraria uma peça fundamental na editora em construção.

Ao longo dos anos e décadas seguintes, paulinos e paulinas abririam livrarias por todo o país - eles afirmam que, por vezes, a instalação de uma loja em determinada cidade ocorria por solicitação direta do bispo local. Assim, em 1961, já havia cerca de dezesseis livrarias no país: quatro no estado de São Paulo (três na capital - sendo duas nos arredores da Sé e uma na Vila Mariana - e uma na cidade de Lins), quatro no Rio Grande do Sul (Porto Alegre, Caxias do Sul, Pelotas e Uruguaiana), duas na cidade do Rio de Janeiro, duas no Paraná (Curitiba e Maringá), e em Belo Horizonte, Salvador, Recife e Fortaleza ${ }^{73}$.

\footnotetext{
${ }^{72}$ Folha da Noite, 26.1.1939, p. 2.

${ }^{73}$ Assim informa a quarta capa de DOUTRINA Cristã. São Paulo, Edições Paulinas, 1961. Outro livro, de 1977, informa a mesma quantidade de lojas (CRISTOFOLINI imc, Pe. Hilário. Deus Mora na Contramão. 4. ed. São Paulo, Edições Paulinas, 1977, p. 134. (Coleção Vida). “imc” refere-se ao Instituto Missões Consolata, do qual Cristofolini era membro).
} 


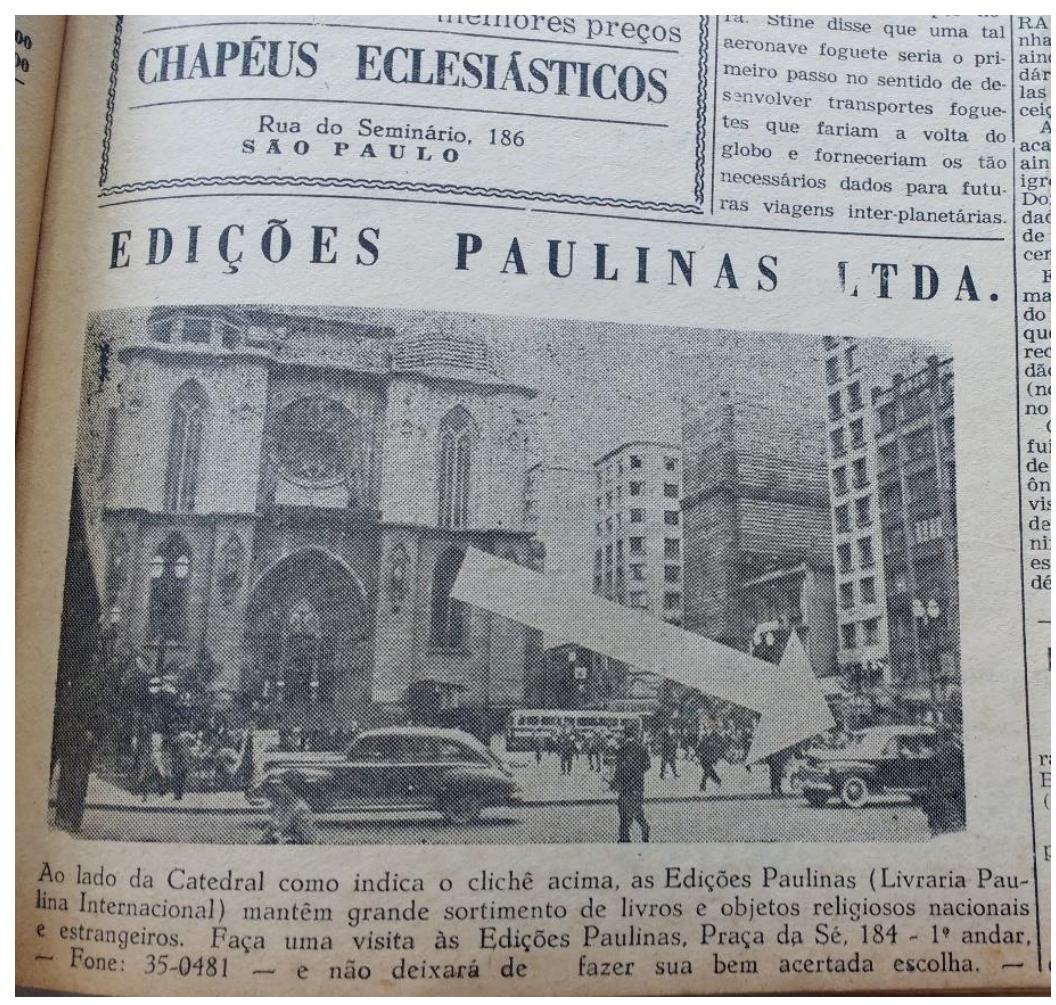

Figura 3: Propaganda da livraria das Edições Paulinas na Praça da Sé, São Paulo. Acima, anúncio de uma loja de vestimentas eclesiásticas. A Imprensa: Semanário Católico Popular, 10.10.1957.

Desde 1932, os paulinos já editavam o que seria sua principal publicação no Brasil, o folheto litúrgico O Domingo, versão do italiano La Domenica. Mais tarde, após o Concílio Vaticano II, quando as missas passam a ser celebradas em português, o folheto passa a trazer o texto da liturgia para acompanhamento dos fiéis. Além de propagandas dos livros paulinos, nas primeiras décadas os textos do pequeno jornal se assemelhavam muito à maioria dos conteúdos católicos populares do período: crônicas catequéticas e moralizantes, em particular, a respeito da família e, é claro, contra o divórcio. Seu título completo era O Domingo: Semanário Católico para as Famílias.

Na capa das edições dos anos 1930 consta a informação: “Filiado à A.J.C.”. Tratase da Associação dos Jornalistas Católicos, presente no Rio de Janeiro e em São Paulo a 
partir da década de 1930 e ativa, na prática, até $1942^{74}$. De acordo com Edgard Leuenroth, o braço paulista da associação participou da já comentada Exposição Universal da Imprensa Católica em Roma, em $1936^{75}$. Portanto, já nos primeiros anos, a congregação ia se inserindo nos círculos editoriais católicos do país, questão que será abordada mais detidamente no Capítulo 3.

A característica principal de $O$ Domingo, que o diferenciava dos demais periódicos paulinos, estava na sua forma de distribuição. Já nos primeiros anos, seus editores visavam vendê-los diretamente às paróquias, a fim de que fossem distribuídos na missa. Cada assinante poderia receber múltiplos exemplares, com desconto progressivo - isto é, era possível que qualquer pessoa o comprasse individualmente, mas, se desejasse receber um número maior de exemplares da mesma edição, o preço seria menor. Em uma edição da década de 1930, informa-se que uma assinatura individual custava $4 \$ 000$ (quatro mil-réis), dez para o mesmo endereço saiam por $2 \$ 500$ cada uma e assim por diante, até $1 \$ 400$ a unidade, no caso de novecentas assinaturas para o mesmo endereço ${ }^{76}$ - o alto número leva a crer que mesmo dioceses tinham interesse em assinar o folheto, para distribuí-lo a suas paróquias.

Assim como o La Squilla e A Imprensa, O Domingo também funcionava como suporte publicitário para a editora. Além de anunciar livros, promovia também sorteios para financiar a congregação. Em 1937, por exemplo, o II Concurso Boa Imprensa, cujos cupons eram vendidos em forma de rifa, sortearia um carro Opel, segundo o jornal, oferecido por uma agência de automóveis da cidade ${ }^{77}$. Naquele ano, os editores

\footnotetext{
${ }^{74}$ Cf. LEUENROTH, Edgard. A Organização dos Jornalistas Brasileiros, 1908-1951. São Paulo, ComArte, 1987, pp. 74, 119 e GURGEL, Eduardo Amaral. Imprensa e Igreja Católica no Início do Século XX: Convergências e Divergências. Tese de Doutorado em Comunicação Social, Universidade Metodista de São Paulo, 2017, pp. 227-247.

${ }^{75}$ LEUENROTH, Edgard. A Organização dos Jornalistas Brasileiros, op. cit., p. 119.

${ }^{76}$ O Domingo. Semanário Religioso para as Famílias. Ano v, n. 37, 12.9.1937, p. 4.

77 O Domingo. Semanário Religioso para as Famílias. Ano v, n. 15, 11.4.1937, p. 4.
} 
afirmavam que a tiragem do jornal era de cinquenta mil exemplares ${ }^{78}$. Nos anos seguintes, os paulinos iniciam a construção de uma nova sede, residência e gráfica, na Vila Mariana. O prédio, na Rua Major Maragliano, extenso e com três andares, hoje abriga um hospital, mas a congregação dos paulinos permaneceria no bairro - assim como a das paulinas.

As primeiras religiosas paulinas, entre elas Dolores Baldi, chegaram em São Paulo meses depois dos padres, e, até 1932, outras sairiam da Itália também para Buenos Aires e Nova York. Afirmam elas que em São Paulo, de início, suas funções praticamente se restringiam a cozinhar e realizar serviços domésticos, mas também começavam a trabalhar com a distribuição do La Squilla e com o atendimento na livraria da Praça da Sé $^{79}$. A partir de 1932, jovens brasileiras começaram a ingressar na congregação ${ }^{80}$.

Em 1934, quando já possuem um espaço para si (também na Vila Mariana, onde em breve abrem sua própria livraria), compram máquinas tipográficas pertencentes aos jesuítas e começam a imprimir livros e A Família Cristã ${ }^{81}$, versão da italiana Famiglia Cristiana, cujos textos, de início, eram voltados para a religiosidade e vida domésticas. As primeiras responsáveis por essa e outras publicações eram muitos jovens. Stefanina Cillario, primeira diretora da revista Família Cristã, contou, em entrevista cedida a Maria Natividade do Nascimento em 2002, que passou seis anos na sede da congregação em Alba e, com dezenove anos, mudou-se para o Brasil ${ }^{82}$.

Alguns anos depois, as duas congregações também se estabeleceram no Rio Grande do Sul. As paulinas em Porto Alegre e, os paulinos, em Caxias do Sul. De acordo

\footnotetext{
${ }^{78}$ O Domingo. Semanário Religioso para as Famílias. Número extraordinário, janeiro de 1937, p. 1.

79 CILlARIO, Stefanina. "O Grão de Mostarda" In: IRMÃS Paulinas. 1931-1981. 50 Anos a Serviço do Evangelho. Coordenação geral de Irmã Stefanina Cillario, fsp. São Paulo, Edições Paulinas, 1981, pp. 2026.

${ }^{80}$ Idem, pp. 30-31.

${ }^{81}$ MARTINI, Catarina A. As Filhas de São Paulo, op. cit., p. 254. Mais tarde, o título do periódico perde o artigo inicial e passa a ser conhecido por Família Cristã.

${ }^{82}$ NASCIMENTO, Maria Natividade Pereira do. A Religiosidade Popular na Revista Família Cristã: Uma Análise das Matérias que Aparecem na Seção Cultura Popular das edições de 1980 a 1981 . Dissertação de Mestrado em Ciências da Religião, PUC-SP, 2007, p. 147.
} 
com Sergio Miceli, aquele estado era um dos principais centros de produção de bens culturais no país na década de 1930 - juntos, São Paulo, Rio de Janeiro e Rio Grande do Sul concentravam $61 \%$ das editoras em $1937^{83}$. Além de ampliar seu reconhecimento nos círculos católicos e aumentar o número de edições e vendas da empresa, a expansão para o Sul marcou uma separação mais acentuada entre as atividades das seções masculinas e femininas. Isto é, possibilitou que as mulheres editassem seus próprios livros e gerenciassem suas livrarias de forma mais independente. Assim como, na Itália, a breve estada em Susa deu fôlego, espaço, experiência e certa autonomia às moças de Alba, Porto Alegre se revela um momento decisivo para as paulinas no Brasil. Livros da década de 1940, cuja publicação é atribuída à Pia Sociedade Filhas de São Paulo, trazem autorizações eclesiásticas (Nihil obstat e Imprimatur) ${ }^{84}$ concedidas em Porto Alegre ${ }^{85}$.

As relações firmadas pelas paulinas com o círculo católico da capital gaúcha são evidenciadas nas páginas de um periódico editado por outro grupo, o Jornal do Dia. Idealizado por João Adolfo Becker, então arcebispo local, e iniciado em 1947 por seu sucessor Alfredo Vicente Scherer, o jornal reunia intelectuais católicos, como aqueles ligados à recém-fundada $\mathrm{PUC}^{86} \mathrm{e}$ à Congregação Mariana, que se contrapunham ao grupo da Livraria do Globo ${ }^{87}$.

\footnotetext{
${ }^{83}$ MICELI, Sergio. Intelectuais e Classe Dirigente no Brasil (1920-1945). São Paulo, Difel, 1979, p. 84. ${ }^{84}$ O Código de Direito Canônico de 1917 - assim como o de 1983 - estabelecia necessidade de autorização do censor diocesano (chamada Nihil obstat, nada obsta) e do ordinário local (o bispo, que concede o Imprimatur, imprima-se). Se membro de instituto religioso, o autor precisa ainda da autorização de seus superiores. Cf. THE 1917 or Pio-Benedictine Code of Canon Law. Translated and edited by Edward N. Peters. San Francisco, Ignatius Press, 2001, tit. 23, chap. 1, can. 1385, p. 466.

${ }^{85}$ DESTÉFANI, Frei Benvindo. Gravetos e Fagulhas! Porto Alegre, Pia Sociedade São Paulo, 1941. Logo abaixo de "Pia Sociedade São Paulo" (denominação ao mesmo tempo genérica para a congregação, mas também específica para a seção masculina), o colofão informa "Filhas de São Paulo", com os endereços das paulinas em São Paulo e Porto Alegre. Uma nova edição do mesmo livro sairia em 1948, impressa na tipografia das Filhas de São Paulo na capital paulista, já sob a marca Edições Paulinas (DESTÉFANI, Frei Benvindo. Gravetos e Fagulhas! São Paulo, Edições Paulinas, 1948).

${ }^{86} \mathrm{Na}$ qual as próprias paulinas chegam a trabalhar, em uma livraria universitária aberta em 1960. Cf. Jornal do Dia, 26.5.1960, p. 3.

${ }^{87}$ MONTEIRO, Lorena Madruga. "O Resto Não é Silêncio. Polêmica e Polarização do Campo Intelectual em Porto Alegre nos anos 1940”. Perspectivas, São Paulo, vol. 40, pp. 121-143, jul./dez. 2011.
} 
De acordo com José Oscar Beozzo, a partir de 1930,

[é no Rio Grande do Sul,] nas regiões de colonização alemã e italiana, que vamos encontrar a Igreja no exercício de uma absoluta hegemonia sobre a sociedade civil, com uma enorme vitalidade de vocações sacerdotais e religiosas, com uma rede de cooperativas de crédito, produção e consumo entre os colonos, uma sólida classe de pequenos proprietários, pequenos industriais e comerciantes inteiramente ligados à Igreja, $[. .$.$] jornais e boletins e finalmente laços bastante importantes$ de militares e políticos com a Igreja. [...] A religião constitui a tessitura mesma dessas sociedades ${ }^{88}$.

Desde o primeiro ano do Jornal do Dia, 1947, já há anúncios das paulinas:

Aos snrs. Vigários e aos diretores de colégios católicos A Pia Sociedade Filhas de São Paulo abriu recentemente uma Livraria, novo centro de difusão do Apostolado da Imprensa.

Grande sortimento de livros nacionais e estrangeiros, santinhos, estampas, terços, artigos para presentes.

Façam suas encomendas e visitem a Livraria São Paulo, dirigida pelas Irmãs Paulinas.

Rua Dr. Flores n. 239 - Porto Alegre ${ }^{89}$

No mesmo ano, um aviso estampado na capa do jornal informa que a Livraria São Paulo "está autorizada a receber pedidos de assinaturas e anúncios para o Jornal do Dia" e que "no mesmo local acha-se instalado um posto de venda avulsa desta folha" 90.

No periódico, identifica-se um esforço das paulinas de integração à vida cultural, religiosa e comunitária da cidade, sobretudo a partir da década de 1950. Elas promoviam, por exemplo, rifas - uma delas sorteou terrenos no litoral $^{91}$ - e tardes de autógrafos com autores locais publicados pela editora ${ }^{92}$, além de participarem de um cineclube católico,

\footnotetext{
${ }^{88}$ BEOZZO, José Oscar. "A Igreja entre a Revolução de 1930, o Estado Novo e a Redemocratização". In: FAUSTO, Boris (org.). História Geral da Civilização Brasileira. Rio de Janeiro, Bertrand Brasil, 2007, t. III (O Brasil Republicano), vol. 11 (Economia e Cultura [1930-1964]), pp. 340-344.

${ }^{89}$ Jornal do Dia, 25.5.1947, p. 5. O acervo parcial do Jornal do Dia está disponível na Hemeroteca Digital da Biblioteca Nacional.

${ }^{90}$ Jornal do Dia, 26.10.1947, p. 1. A autorização dura até o último ano do jornal, pois um anúncio semelhante é publicado na edição de 26.9.1965, p. 3.

${ }^{91}$ Jornal do Dia, 10.4.1955, p. 3.

${ }^{92}$ Jornal do Dia, 30.12.1960, p. 2.
} 
chamado Pro Deo ${ }^{93}$. Mais uma vez, a imprensa periódica era suporte importante para divulgação e financiamento do trabalho editorial.

A editora não chegou a ter uma coluna fixa no jornal, mas algumas matérias traziam como título "Novidades Paulinas"94 ou mesmo "Edições Paulinas" "95. No entanto, diferentemente dos padres da região, que assinam colunas, as religiosas são sempre referidas de forma genérica, como grupo. Nunca assinam matérias e tampouco são citadas pelo nome: todas são "irmãs paulinas". A comparação pode ser feita dentro da própria congregação, e não se restringe ao Rio Grande do Sul. Nos primeiros anos de atuação em São Paulo, pelo fato de receberem o sacramento da ordem e rezarem missas - cerimônias passíveis de notícia pública - os paulinos eram frequentemente mencionados, por nome, nos jornais, diferentemente das paulinas, sempre tratadas de forma coletiva e impessoal.

Em 1954, as paulinas fundam em Porto Alegre um "juvenato" - isto é, uma escola destinada a jovens que seguiriam na vida religiosa -, cujo fim era "servir de casa de formação das candidatas a ingresso na congregação"96. Em depoimento concedido em 2019, a atual diretora editorial da Paulinas, Vera Ivanise Bombonatto, relatou que entrou para a congregação em Porto Alegre, em 1956, ainda na adolescência ${ }^{97}$, tendo cumprido ali as primeiras etapas da formação religiosa, que são cinco: aspirantado, postulado, noviciado, votos temporários e votos perpétuos ${ }^{98}$. A partir do noviciado, as moças eram enviadas a São Paulo99. Segundo Vera Bombonatto, quando de seu ingresso na casa de

\footnotetext{
${ }^{93}$ Seis irmãs paulinas foram as primeiras alunas matriculadas no Curso de Iniciação Cinematográfica do cineclube, realizado na PUC-RS em 1956 (Jornal do Dia, 4.5.1956, p. 11); elas também possuíam filmes italianos que exibiam no cineclube ("Filmes Catequéticos no Cine Clube Pro Deo", Jornal do Dia, 1.5.1958, p. 9); contribuíam com equipamento técnico (Jornal do Dia, 10.9.1959, p. 11) e publicavam guias com "cotação moral" dos filmes em cartaz na cidade, guias que eram afixados à porta de sua livraria (cf. Jornal do Dia, edições de 1.1.1956, p. 5 e de 14.1.1960, p. 11).

${ }^{94}$ Jornal do Dia, 8.10.1960, p. 3.

${ }^{95}$ Jornal do Dia, 13.12.1959, p. 18.

${ }^{96}$ A inauguração contou com a presença do arcebispo Alfredo Vicente Scherer. Jornal do Dia, 18.12.1954, p. 3.

${ }^{97}$ Depoimento de Vera Ivanise Bombonatto, 12.4.2019.

${ }^{98}$ Idem.

${ }^{99}$ CILLARIO, Stefanina \& SCARAMUZZI, Fátima. "Porto Alegre - 1936". In: IRMÃS Paulinas. 19311981, op. cit., p. 163.
} 
Porto Alegre, já havia ali uma máquina Intertype, espécie mais moderna de linotipo e, além de São Paulo, também em Curitiba (outra cidade para a qual a congregação se expandiria já nas primeiras décadas) se realizavam trabalhos de composição e impressão ${ }^{100}$.

A seção masculina também começava a receber membros brasileiros. A forma de ingresso nas congregações ocorria da mesma forma que na Itália. Ao fim de um livro editado pelos paulinos de São Paulo em 1949, lê-se:

Em todas as casas aceitam-se meninos e jovens que aspiram à vida religiosa na Pia Sociedade de São Paulo. Todos os aspirantes, ao mesmo tempo que estudam se exercem também no apostolado da imprensa executando trabalhos tipográficos durante algumas horas do dia ${ }^{101}$.

Não é possível afirmar, com as fontes ora disponíveis, se havia alguma forma de remuneração a esses aprendizes. Sabe-se, entretanto, que a prática do aprendizado não remunerado em tipografias brasileiras do período era comum ${ }^{102}$. Entretanto, conforme ingressassem oficialmente na congregação, os religiosos tornavam-se financeiramente dependentes desta.

Assim como as meninas, eles também entravam muito cedo na congregação. Uma pequena biografia do padre Bernardo Bósio, um dos primeiros paulinos brasileiros, relata que, nascido em 1930 no interior de São Paulo, ingressou na Pia Sociedade em 1942, com doze anos; aos dezesseis, iniciou o noviciado e pouco depois emitiu as primeiras profissões religiosas; aos vinte, "iniciou o curso de Teologia no Brasil em 1950 e, a pedido do fundador, Padre Tiago Alberione, que determinou que a Teologia fosse feita em Roma,

\footnotetext{
${ }^{100}$ Depoimento de Vera Ivanise Bombonatto, 12.4.2019.

101 Assim avisa um texto sobre a congregação na última página de BÍBLIA Sagrada. Vol. IV: Novo Testamento. Traduzido da Vulgata e anotado pelo Pe. Matos Soares. São Paulo, Pia Sociedade de São Paulo, 1949. Trata-se de uma tradução portuguesa a partir da vulgata latina, única versão bíblica publicada pelas Edições Paulinas até a edição da Bíblia de Jerusalém, na década de 1970.

102 Ver, por exemplo, o texto de 1924 de CANELLAS, Antonio Bernardo. Questões Profissionais da Indústria do Livro. São Paulo, Com-Arte, 2016, pp. 48-50.
} 
viajou para lá” em 1951; em 1954, com 24 anos, foi ordenado sacerdote e retornou ao Brasil, onde trabalharia em diversos setores da editora até seu falecimento, em $1992^{103}$. Conforme aumentava o número de ingressantes locais e, é claro, conforme os empreendimentos das congregações iam se consolidando fora da Itália, tornavam-se cada vez mais autônomas com relação a Alberione. Como vimos acima, no caso de Bósio, o fundador exerceria até seu falecimento, em 1971, um poder determinante sobre a congregação religiosa. Mas a edição propriamente dita começava a escapar de sua supervisão direta. Em Alba, nas primeiras décadas de sua atuação editorial, Alberione havia exercido uma função muito semelhante à do editor típico até meados do século XX. Isto é, era uma espécie de empresário, “dono” de editora, e, ao mesmo tempo, realizava um trabalho intelectual junto aos livros, decidindo o que deveria ou não ser publicado. Nesse sentido, era um publisher. Com a expansão das empresas paulinas em outros países, esse trabalho editorial é, necessariamente, delegado a outros religiosos.

Mas o superior, que mantinha sua autoridade religiosa, buscaria manter também a editorial. Sob esse aspecto pode-se compreender sua obra $O$ Apostolado da Edição, de 1944, um guia para as congregações paulinas, tanto a respeito da vida religiosa quanto, e sobretudo, à prática do "apostolado da edição", que abarcava o "apostolado da imprensa" (livros e periódicos), o do cinema e o do rádio, expandindo seu objetivo inicial de trabalho com a imprensa. Até o Concílio Vaticano II (1962-1965), “comunicação” ou “comunicações sociais" não eram termos correntes nos meios eclesiásticos, daí a palavra "edição" ser utilizada por Alberione em sentido amplo. Para o autor, entretanto, é inegável o protagonismo das letras impressas. No livro de 1944, ele fornece orientações gerais sobre como seus discípulos deveriam tratar cada um dos temas a serem publicados, sendo eles:

${ }^{103}$ VIDAS Que Valeram a Pena (1931-2014). São Paulo, Padres e Irmãos Paulinos, 2014, pp. 28-29. 
A Sagrada Bíblia; a obra bíblica; história eclesiástica; a Santíssima Virgem; Sagrada teologia; ascética e mística; liturgia; os santos padres; obra catequética; os papas; hagiografia e biografia, apologia sagrada; o jornal; revistas e publicações periódicas; boletim paroquial; leituras amenas; literatura para a infância e para a pré-adolescência; missiologia; textos escolares; geografia; revistas bibliográficas; política, ciências sociais e filosofia ${ }^{104}$.

De fato, essa seria, basicamente, a formação do catálogo das Edições Paulinas pelas próximas décadas. Alguns dos gêneros ficariam restritos à edição pelos homens da congregação, que tinham exclusividade para publicar Bíblias, teologia e filosofia. Já as mulheres paulinas tinham grande espaço em seu catálogo para livros de catequese e pastoral, mas não se restringiam a eles. Quanto aos últimos temas citados por Alberione, haveria um volume relevante de ciências sociais e filosofia, mas sempre ligados, de alguma forma, ao cristianismo. Em relação à política, o superior afirma que poderiam “servir de orientação geral” aos editores de sua congregação as seguintes normas:

1. Tenha sempre presentes as relações da Igreja com o Estado: trata-se de duas sociedades perfeitas, independentes, que têm territórios e súditos comuns. Entre elas não deve haver oposição nem paralelismo, mas concórdia: em matéria de religião, o Estado está subordinado à Igreja e depende dela com uma dependência direta, negativa e $\operatorname{positiva}^{105}$.

Mas, prosseguia Alberione, a política vinha somente após a fé, e o alinhamento com a Igreja era prioritário:

2. Sua política seja a do Papa. Pronuncie-se somente quando se trate de fé e de moral, e então se regulará deste modo: a) Submeta-se e inculque submissão às leis que não são injustas. b) Quando se trate de leis injustas, se subtrairá a elas da maneira que deve fazer todo cristão fiel. E, caso tenha liberdade de palavra e de imprensa, proteste energicamente em defesa dos direitos de Deus, da Igreja e das almas.

${ }^{104}$ ALBERIONE, Santiago. El Apostolado de la Edición. Manual Directivo de Formación y de Apostolado, op. cit.

${ }^{105} \mathrm{Idem}, \S 365$. 
Quando não possa fazer obra direta de defesa, recorra à oração e ao sacrifício $^{106}$.

De fato, no Brasil, a editora buscaria manter um alinhamento com a hierarquia católica, fosse vaticana, fosse episcopal. Já as leis injustas ${ }^{107}$ dariam margem a diversas interpretações, e a política editorial se transformaria acompanhando o movimento da Igreja no Brasil e, de certa forma, do próprio processo histórico em que os editores iam se inserindo.

Contemporaneamente à publicação d'O Apostolado da Edição, as editoras italianas se unificam sob a marca Edizioni Paoline, e mesmo ocorre no Brasil: em meados dos anos 1940, as empresas administradas por paulinas e paulinos começam a publicar sob uma marca unificada, Edições Paulinas, ainda que seguissem trabalhando separadamente. O nome da editora ia se tornando, desse modo, comum às obras editadas pela congregação em todo o país, tanto pelas seções femininas quanto pelas masculinas. Ela é beneficiada pela crescente popularidade dos religiosos nos meios católicos regionais, mas mantém-se sob as orientações de Alberione e do modelo italiano.

Todas as alterações da marca seguiriam as diretrizes da editora italiana. De início os livros aqui publicados trazem apenas o brasão das congregações, com as inscrições P.S.F.S.P. (Pia Sociedade Filhas de São Paulo) ou P.S.S.P. (Pia Sociedade de São Paulo). A partir de fins dos anos 1950, quando expandem sua estrutura gráfica, os livros passam a estampar a marca EP. De início desenhadas em tipografia bastante formal, as letras são separadas por uma grande cruz. Em uma espécie de laicização da marca, que a colocava lado a lado com outras editoras, após a segunda metade da década de 1960 a cruz é removida e as letras são simplificadas. Mas somente a partir dos anos 1970 torna-se

\footnotetext{
106 Idem, ibidem.

${ }^{107}$ Há uma referência bíblica: “Ai dos que promulgam leis iníquas, os que elaboram rescritos de opressão para desapossarem os fracos do seu direito e privar da sua justiça os pobres do meu povo, para despojar as viúvas e saquear os órfãos" (Isaías 10:1-2).
} 
totalmente legível; agora, a tipografia moderna e a popularidade dos livros fazia o EP ser facilmente reconhecido pelos leitores.
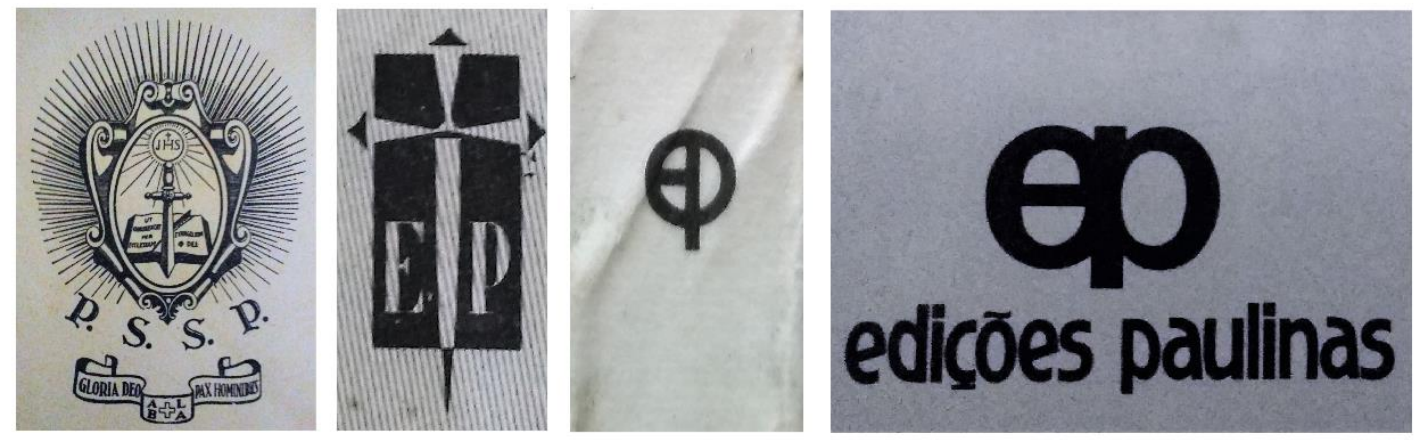

Figura 4: As marcas da editora ao longo do tempo

Nesse período é editada uma das primeiras coleções da editora, a Série Primavera, com traduções de romances populares da mesma série publicada pelas Edizioni Paoline. O primeiro volume encontrado data de $1957^{108}$. Em 1962 é lançada a Nova Série Primavera.
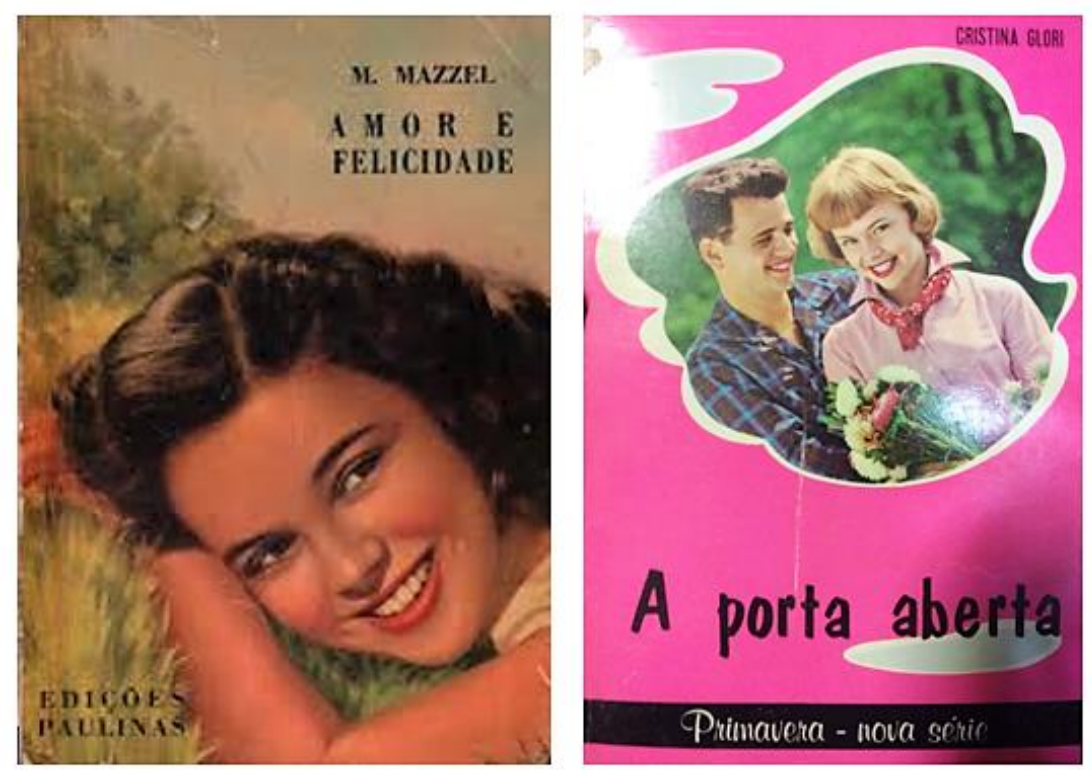

Figura 5: Capas da Série Primavera e da Nova Série Primavera, respectivamente.

\footnotetext{
108 MAZZEL, Maximiliano. Amor e Felicidade. São Paulo, Edições Paulinas, 1957. (Série Primavera). Todos os exemplares consultados da Série Primavera e da Nova Série Primavera pertencem ao acervo particular da Paulus Editora.
} 
Mais colorida e moderna, com fotografias e cores vibrantes ao molde das revistas, a Nova Série continua almejando o mesmo público, isto é, de jovens leitoras, mantendo a ideia de "leituras amenas" para concorrer com os romances de ampla difusão. A quarta capa de um novo volume argumenta que a primeira coleção havia sido um sucesso:

Certo de encontrar a preferência dos leitores, lançamos a coleção "Primavera". A aceitação por parte da nossa mocidade foi tão unânime, a acolhida tão lisonjeira, que nos obrigou a várias reedições num prazo relativamente breve. Essa gentil preferência estimulou também de nossa parte maiores cuidados e mais acuradas buscas na seleção dos originais $^{109}$.

Embora ainda se mantenha, em termos gerais, na lógica da boa imprensa, isto é, de bons romances para se contrapor aos escandalosos, o discurso torna-se mais comercial. Não há, por exemplo, a indicação de um padre ou autoridade; o que importa é a boa acolhida que os livros teriam entre os próprios jovens, a "mocidade" consumidora, que assume um papel de destaque. Foi, afirma a nota, a aprovação dos leitores que legitimou a coleção. Para os efeitos do paratexto, não importava se a antiga coleção havia realmente tido bons resultados. Ela serve apenas como fiadora para a nova série, pois continua o editor:

E eis que agora surge a Nova Primavera, que, embora perfilhando os critérios fundamentais da coleção: "Faz verdadeiramente bem quem une o útil ao agradável", abrange horizontes muito mais amplos, incluindo autores de nossa terra; romances do momento, de grande sucesso, dramas vigorosos e sumamente atraentes. Estamos certos que a mocidade continuará a encorajar-nos com sua preferência ${ }^{110}$.

O útil - a boa leitura - apresentava-se sob a forma do prazeroso. Nessa nota da quarta capa, os editores buscam inserir a nova coleção em um circuito mais amplo:

${ }^{109}$ GLORI, Cristina. A Porta Aberta. São Paulo, Edições Paulinas, 1962. (Nova Série Primavera).
${ }^{110}$ Idem. 
anunciam os romances como leituras do momento, de sucesso e atraentes. As vendas, assim como as de quase todos os outros produtos da editora, eram favorecidas pela marca da editora e pelos locais de venda, isto é, as livrarias paulinas: livros populares, mas com o aval de religiosos católicos. Mais do que um incentivo à leitura, era um incentivo à compra, que poderia ser ostentada sem prejuízo à imagem de retidão moral de sua leitora.

Outra coleção de romances também era editada pelos paulinos. Mais sóbria e menos colorida, Os Grandes Romances do Cristianismo tinha títulos também populares, mas com ares mais adultos e clássicos, como Os Noivos, de Alexandre Manzoni (1961), Ben-Hur, de Lewis Wallace (1966) e A Cabana do Pai Tomás, de Harriet Beecher Stowe (1968). O título da coleção levanta questões sobre a própria concepção de cultura que se queria difundir. Embora não se trate de livros religiosos, são romances considerados moralmente adequados, e a editora escolhe inseri-los na tradição que denomina “cristianismo".

Mantinha-se, portanto, a concepção de "boa imprensa", mas com um aumento da importância do elemento comercial. Ao longo da década seguinte, essas coleções não seriam mais editadas. A partir dos anos 1970, as "leituras amenas" seriam não mais romances, mas livros de reflexões espirituais e comportamentais, alguns se aproximando da autoajuda, como abordaremos mais adiante.

Então, as obras de ficção se restringiriam, quase exclusivamente, às infantis e infanto-juvenis, que formariam, inclusive, grande parte do catálogo das editoras paulinas. Mas, para as crianças também eram publicados livros religiosos. Um missal destinado àqueles que fariam a primeira comunhão foi publicado pelos paulinos em 1958. Ali, notase a marca dos livros ritualísticos da editora: a tipografia em duas cores, com o texto em preto e destaques em vermelho. Por outro lado, há elementos graficamente mais 
sofisticados. Além de ilustrações de Cristo e de santos, há fotografias coloridas, representando um padre e seus assistentes em diversos momentos da missa ${ }^{111}$.

Após trinta anos de estruturação religiosa, editorial, gráfica e comercial no Brasil, as Edições Paulinas mantinham, entretanto, muitas das concepções de inícios do século sobre o que consideravam uma "boa imprensa". Se, até aqui, as transformações na editora haviam sido quantitativas, isto é, expandindo-se sem grandes mudanças, nas décadas seguintes a empresa passaria por transformações qualitativamente significativas.

\subsection{2: Mudanças de Rumos. A Abertura para um Novo Mundo}

Em 1956, a editora dos dominicanos franceses Éditions du Cerf publicou a primeira edição integral da Bible de Jérusalem. A tradução, feita a partir de "originais" hebraicos e gregos fora realizada pelos acadêmicos da École Biblique et Archéologique Française de Jérusalem, também sob direção dominicana. Na década seguinte, seu modelo seria reproduzido em diversas línguas europeias, o que significava a tradução do texto bíblico dos originais mais a versão dos paratextos, como introduções e notas de rodapé, redigidos em francês pela École Biblique.

Essa onda de traduções diretamente do original deveu-se não apenas ao sucesso editorial da primeira versão francesa, mas também ao próprio Concílio Vaticano II, iniciado em 1962, que marcaria um novo momento na Igreja. Um de seus documentos mais importantes, a constituição dogmática Dei Verbum, Sobre a Revelação Divina, insistia na centralidade da Bíblia para toda a Igreja, inclusive os leigos, afirmando ser preciso que os fiéis tivessem "acesso patente à Sagrada Escritura"112. Por isso, "A Igreja procura com solicitude maternal que se façam traduções aptas e fiéis nas várias línguas,

\footnotetext{
${ }^{111}$ REGI, Glória. Missal. São Paulo, Edições Paulinas, 1958.

112 PAULO VI. Constituição Dogmática Dei Verbum sobre a Revelação Divina. Roma, 18 de novembro de 1965.
} 
sobretudo a partir dos textos originais dos livros sagrados" ${ }^{" 13}$. As edições, no entanto, deveriam trazer explicações do texto, para seu "reto uso" pelos fiéis:

Compete aos sagrados pastores, depositários da doutrina apostólica, ensinar oportunamente os fiéis que lhes foram confiados no uso reto dos livros divinos, de modo particular do Novo Testamento, e sobretudo dos Evangelhos. E isto por meio de traduções dos textos sagrados, que devem ser acompanhadas das explicações necessárias e verdadeiramente suficientes, para que os filhos da Igreja se familiarizem dum modo seguro e útil com a Sagrada Escritura e se penetrem de seu espírito. Além disso, façam-se edições da Sagrada Escritura, munidas das convenientes anotações, para uso também dos não cristãos, e adaptadas às suas condições ${ }^{114}$.

Além da recomendação conciliar, o que parece ter motivado as Edições Paulinas do Brasil a publicar a Bíblia de Jerusalém foi sua versão italiana de 1971, pois, no ano seguinte, o editor e padre paulino Carlos D. Vido assinaria um contrato com os dominicanos franceses para publicar a Bíblia de Jerusalém "em todo o mundo de língua portuguesa"115, mas não abarcava as editoras paulinas de outros países, que, embora mantivessem uma circulação de traduções e obras entre si, realizavam acordos editoriais independentes, delimitados a seus países. Em italiano, a Bibbia de Gerusalemme saiu pela EDB, Edizioni Dehoniane Bologna, comandada pelos dehonianos (pertencentes à Congregação dos Sacerdotes do Sagrado Coração de Jesus), a partir de 1971. Em espanhol, a Bíblia de Jerusalén foi publicada pela basca Desclée de Brouwer, católica, mas leiga, desde 1967, que a distribuiu também para a América Latina, com uma versão latinoamericana do texto. Uma das traduções mais célebres, por ter contado com a

\footnotetext{
${ }^{113}$ Idem. Grifo meu. O documento indicava também a possibilidade de Bíblias ecumênicas: "Se, porém, segundo a oportunidade e com a aprovação da autoridade da Igreja, essas traduções se fizerem em colaboração com os irmãos separados, poderão ser usadas por todos os cristãos" (Idem).

${ }^{114}$ Idem. Grifo meu.

${ }^{115}$ Contrato de edição assinado por Gabriel Ferrier, directeur commerciel et financier de Les Éditions du Cerf, e Carlos D. Vido, chefe do departamento editorial das Edições Paulinas, em Paris, 10.4.1972. Arquivo do Departamento de Direitos Autorais da Editora Paulus.
} 
participação de J. R. R. Tolkien, foi aquela para o inglês, lançada pela primeira vez pela nova-iorquina (e secular) Doubleday em 1966.

$\mathrm{O}$ acordo com as Edições Paulinas estabelecia que os editores brasileiros traduziriam "diretamente do original (hebraico ou grego) ao português, tomando por texto de base o texto seguido pelos tradutores da Bible de Jérusalem", mas "com as mesmas escolhas de variações, correções críticas e transposições" e seguindo "a interpretação do texto que exprimem as notas da Bible de Jérusalem"116. Já os "títulos, subtítulos, introduções, notas e apêndices" deveriam ser traduzidas "integral e exatamente" do francês para o português, assim como as "referências marginais da Bible de Jérusalem" seriam "reproduzidas" $" 117$.

O documento exigia que a Bíblia completa fosse publicada e não permitia edições separadas dos livros. No entanto, uma cláusula adicional permitia uma edição à parte do Novo Testamento ${ }^{118}$, mas os direitos autorais cobrados pelos dominicanos para esta edição seriam um pouco maiores que para a integral ${ }^{119}$. Mesmo assim, a permissão foi vantajosa para os paulinos: como o processo de tradução era muito longo, a edição neotestamentária pôde ser publicada já em 1976; em 1979 foi feito um novo contrato para a publicação de uma edição com Novo Testamento e Salmos, o livro mais popular do

\footnotetext{
116 "Les textes bibliques seront traduits directement de l'original (hébreu ou grec) em portugais, en prenant pour texte de base le texte suivi par les traducteurs de la Bible de Jérusalem (avec les mêmes choix de variantes, corrrections critiques et transpositions) et en suivant l'interpretation du texte qu'expriment les notes de la Bible de Jérusalem" (idem).

117 "Les titres, sous-titres, introductions, notes et apêndices de la Bible de Jérusalem, seront traduits exactemente et intégralement du français en portugais. Les références marginales de la Bible de Jérusalem seron reproduites" (Idem).

${ }_{118}$ Idem.

119 "Para tiragem ilimitada" da "edição comum" do Novo Testamento a Éditions du Cerf cobraria 5\%, já para a "edição comum" da Bíblia completa, $4 \%$ até 20 mil exemplares e $6 \%$ a partir dessa quantidade. Havia também menção a "edições escolares e populares", "vendidas em livraria, com notas e introduções abreviadas, submetidas a aprovação [da editora francesa]", cuja participação seria de 2,2 e $3 \%$ respectivamente. Outro caso peculiar mencionado no contrato é o das "edições missionárias" da Bíblia de Jerusalém completa, que se referia àquelas vendidas em "circuitos diferentes do circuito comercial normal", cujo direito autoral seria de apenas $1 \%$ (Idem).
} 
Antigo Testamento; e a integral, com os dois testamentos completos, sairia apenas em 1981.

Sob direção editorial de Tiago Giraudo e coordenação editorial de Carlos D. Vido, editores paulinos, ela foi traduzida por dezesseis acadêmicos e, além de revisores exegéticos, passou pela revisão literária de Antonio Candido, Alfredo Bosi e Antonio da Silveira Mendonça, ligados à Universidade de São Paulo, o que representa uma aproximação entre a editora e a intelectualidade (não necessariamente católica) de São Paulo.

A edição integral de 1981 trazia uma reprodução do Imprimatur manuscrito do arcebispo de São Paulo, Paulo Evaristo Arns, datado de novembro de $1980^{120}$. Havia também uma apresentação, assinada por “Os Editores”, que buscava valorizar a edição e o processo de tradução:

A Bíblia de Jerusalém, em português, foi esperada com atenção, e até mesmo com certa preocupação. Depois de cinco anos da publicação do Novo Testamento, felizmente, entregamos aos leitores brasileiros a edição desta Bíblia tão desejada.

Com efeito, quando há mais de vinte anos apareceu a primeira edição francesa, a Escola Bíblica de Jerusalém, dirigida pelos Padres Dominicanos, conseguira realizar um acontecimento histórico de importância para a vida da Igreja e para a reflexão teológica. Aquela edição atualizava e divulgava os conhecimentos sobre a Sagrada Escritura; agora qualquer leitor atento poderia deles se beneficiar.

Naquela época a tradução francesa com as introduções, as notas, as referências, era um balanço inteligente e crítico de quase um século de pesquisas nos estudos bíblicos. As edições que se seguiram e as traduções em várias línguas foram a prova do sucesso da obra que passou a ser o livro de base para estudantes, professores, catequistas e pregadores da Palavra de Deus $[\ldots]^{121}$.

\footnotetext{
${ }^{120}$ A mesma folha de créditos com o Imprimatur também informa que a tradução foi feita a partir da edição revista e aumentada francesa, de 1973 (A BÍBLIA de Jerusalém. São Paulo, Edições Paulinas, 1981, p. 6). O próprio contrato de 1972 pedia que os tradutores acompanhassem "os progressos da Escola Bíblica de Jerusalém" e também os convidava ao trabalho de revisão (Contrato entre Les Éditions du Cerf e Edições Paulinas, 10.4.1972).

${ }^{121}$ A BÍBLIA de Jerusalém, op. cit., 1981, p. 7. Grifos meus.
} 
Dessa forma, há um esforço dos editores para que a Bíblia de Jerusalém se torne uma edição de referência, inclusive, em âmbito acadêmico. Para isso contribuía, também, a folha de créditos, com o rol de tradutores e revisores especialistas em estudos bíblicos e em literatura - entre eles, os já comentados docentes da USP. Por todos os elementos que conformaram seu status, essa Bíblia, com suas posteriores revisões, ainda hoje é a mais utilizada em trabalhos acadêmicos, sobretudo nos laicos.

Mesmo antes da conclusão do processo de edição, o fato de assumirem e levarem a cabo empreendimento como esse demonstra que a editora já possuía, ao assinar o contrato em 1972, outra dimensão, muito distinta de suas primeiras décadas no Brasil. A própria congregação crescia muito em todo o mundo. Em 1978, por exemplo, início do pontificado de João Paulo II, havia 2650 religiosas paulinas no mundo, espalhadas por 225 casas. Já as 77 casas da congregação masculina abrigavam 1192 paulinos, sendo 548 deles sacerdotes ordenados ${ }^{122}$. Naquele mesmo período, como comentamos acima, havia cerca de dezesseis livrarias das Edições Paulinas no Brasil ${ }^{123}$, mas a empresa realizava um esforço de centralizar suas atividades, buscando evitar que as diversas casas e comunidades espalhadas pelo país viessem a formar empreendimentos próprios, fosse no sentido propriamente editorial, fosse financeiro.

O grupo dos paulinos de Caxias do Sul, que, conforme comentado, estava bem integrado ao círculo intelectual católico regional (como também as paulinas de Porto Alegre), crescia e ganhava autonomia. Eles chegam, inclusive, a abrir uma entidade jurídica própria, financeiramente independente - o mesmo fariam os paulinos do Rio de Janeiro com sua livraria. Uma assembleia geral, realizada em São Paulo em 1972, determina a dissolução dessas pessoas jurídicas de Caxias e do Rio e as reincorpora à

\footnotetext{
${ }^{122}$ Dados enviados pelas congregações ao Vaticano em 1978. ANNUARIO Pontificio per l'Anno 1979. Città del Vaticano, Libraria Editrice Vaticana, 1979, pp. 1226, 1325.

${ }^{123}$ CRISTOFOLINI imc, Pe. Hilário. Deus Mora na Contramão, op. cit., p. 134.
} 
sociedade principal, com sede na Vila Mariana ${ }^{124}$. Isso não impediu que os religiosos de Caxias do Sul seguissem editando e imprimindo livros em sua gráfica, mas, da mesma forma que na congregação feminina, ocorria uma centralização na empresa.

As editoras também passavam por reformas religiosas e editoriais, sobretudo a seção feminina. Em suas primeiras décadas no Brasil, o trabalho das irmãs paulinas com os livros restringia-se, pelo menos formalmente, à composição e impressão, além da divulgação e venda. Foi a partir de meados dos anos 1950 que elas começaram a, de fato, trabalhar com os textos propriamente ditos, isto é, com maior autonomia e poder de decisão editorial. Esta diferença em relação aos paulinos devia-se sobretudo à estrutura da congregação, cujas prescrições às mulheres eram especialmente conservadoras e restritivas. Tecla Merlo, superiora geral das Filhas de São Paulo até seu falecimento, em 1964, não deixou muitos escritos. Mas o registro de suas conferências às paulinas de diversas regiões do mundo - inclusive às brasileiras, quando de suas visitas ao país deixa claro os limites rígidos que se pretendia impor a essas religiosas, por lidarem elas com trabalho tido como perigoso:

Vocês sabiam que as Filhas de São Paulo têm tentações que as outras congregações não têm? Quais são as tentações das Filhas de São Paulo? Principalmente duas. A primeira é ler livros inadequados [...]. É uma grande tentação. Antes de ler um livro, sempre peça permissão. Algumas irmãs estão arruinadas e perderam a vocação por ler livros inadequados. "Os livros que temos em casa - algumas dirão - são ruins?" Não são ruins, são todos bons, mas nem todos são adequados para nós, para as irmãs. Antes de ler um livro, mesmo que impresso por nós, peça sempre permissão à superiora [...]. Essa é uma tentação que

124 “Estatuto Social da Pia Sociedade de São Paulo", 1972. O documento, lavrado em cartório após Assembleia Geral Extraordinária da Pia Sociedade de São Paulo, 30 de setembro de 1972, foi anexado a um dossiê realizado em 1983 pelo Serviço Nacional de Informações, que espionou o padre paulino Virgílio Ciaccio, então responsável pelo semanário litúrgico O Domingo. Arquivo Nacional, Fundo SNI, Série Agência Central, Informação n. 083/19/AC/83. 
as Filhas de São Paulo têm e que as outras irmãs não têm, por que quem tem tantos livros disponíveis? Nenhuma [outra congregação] ${ }^{125}$.

A advertência, proferida no Rio de Janeiro no início de 1960, seria repetida às paulinas de São Paulo e Lisboa nas semanas seguintes. A estas, a superiora diria:

Você começa a abrir o livro, lê algumas palavras, depois o índice, lê um capítulo um pouco disfarçadamente e se arruína. Cuidado com isso! Veja, temos tantos livros à mão, são livros ruins? Não, são apenas livros que não são adequados para nós, livros que fazem bem ao povo, ao povo, mas não a nós. A maioria dos livros que difundimos não são livros que possamos ler, não são para as freiras. São bons livros, mas devemos ler apenas os que nos são indicados [...]. Repito: lendo livros inadequados, várias Filhas de São Paulo perderam a vocação, por isso devemos ter cuidado e sempre pedir permissão. É o diabo que faz as coisas secretamente, que se esconde dentro dessa capa, nas páginas desse livro, é assim mesmo! Ele é esperto, sabe, o diabo! ${ }^{126}$

A própria reiteração do sermão, que também se deu com outras palavras em distintos locais e datas, demonstra que era impossível controlar o que as freiras liam ou deixavam de ler. Afinal, os livros, nas palavras de Tecla, estavam à mão. É claro que algumas paulinas, aquelas que lidassem diretamente com a edição, liam (e deveriam ler) o que publicavam. Mas a congregação era grande e dentro dela havia muitas funções a serem desempenhadas. A advertência da superiora parece se dirigir sobretudo às mais jovens, pois a entrada na congregação ocorria muito precocemente, no início da adolescência: algumas meninas chegavam a ingressar ainda com doze anos ${ }^{127}$. As moças, portanto, não teriam ainda o discernimento necessário para lidar com determinados tipos de escritos.

\footnotetext{
${ }^{125}$ MERLO, Tecla. "Carità e Osservanza. Conferenza alle Figlie di San Paolo. Rio de Janeiro (Brasile), 9 Gennaio 1960”. Un Cuor Solo, un'Anima Sola. Conferenze - Meditazioni 1954-1963. Roma, Edizioni Paoline, 1993, pp. 358-359. A segunda tentação das paulinas, afirma Tecla, era "utilizar dinheiro para comprar para si qualquer coisa que lhe agrade, e escondido. Nunca façam nada escondido!"' (idem, ibidem). 126 MERLO, Tecla. "Alcuni Punti delle Constituzioni. Conferenza alle Figlie di San Paolo. Lisbona (Portogallo), 12 Febbraio 1960”. Un Cuor Solo, un'Anima Sola, op. cit., p. 405.

${ }^{127}$ Foi o caso, por exemplo, de Maria Bernarda Potrich. Nascida em Passo Fundo em junho de 1933, ingressou na comunidade de Porto Alegre em maio de 1946 e seguiria na congregação até seu falecimento, em 2011.
} 
Outro ponto da fala de Tecla chama a atenção: muitos dos livros publicados “fazem bem ao povo, mas não a nós". Há, portanto, a pretensão de afastamento e separação do povo, ou, em termos religiosos, do mundo. Em ocasião distinta, dirigindose às paulinas de Roma, Tecla Merlo criticou o costume prejudicial que algumas delas possuíam de ler romances e assistir a filmes populares: "Somos ou não religiosas? Renunciamos ou não ao mundo? Veja como somos pouco astutas, trazemos o mundo para dentro de nossa casa!" 128 Como vimos, a edição de romances, livros que Merlo não recomendava às paulinas, era frequente, em especial aqueles que se propunham como leituras amenas para moças, para evitar, nas palavras da superiora, a leitura de "romances escandalosos" $" 129$.

Ao longo das décadas de 1960 e 1970, tal rigidez proibicionista sobre as paulinas seria, aos poucos, mitigada. O Concílio Vaticano II, ocorrido entre 1962 e 1965, do qual nos ocuparemos mais detidamente no Capítulo 2, incentivava uma maior inserção da Igreja no "mundo" e conclamava todas as comunidades de vida religiosa católica a uma renovação de suas práticas e preceitos. Institucionalmente, uma das formas de realizá-la seria a convocação de capítulos, espécie de assembleia realizada por congregações religiosas. O primeiro capítulo dos paulinos havia ocorrido em 1957, em Roma. O segundo tem sua primeira seção em 1969 e a segunda em 1971. Já as Filhas de São Paulo se reuniram em 1957, 1964 e, pela terceira vez, entre 1969 e 1971, sempre na Itália. A partir daí ambas as seções realizariam diversos outros capítulos, periodicamente, até os dias de hoje. Note-se, no entanto, a urgência em convocar reuniões, discussões e reformas após o Concílio, que inclusive obrigou a realização de capítulos "de renovação"130 .

\footnotetext{
128 MERLO, Tecla. "Osservanza delle Costituzioni. Conferenza alle Figlie di San Paolo. Roma, Via Antonino Pio, 11 Giugno 1961”. Un Cuor Solo, un'Anima Sola, op. cit., p. 525.

${ }^{129}$ MERLO, Tecla. "I Voti Religiosi. Conferenza alle Figlie di San Paolo. Roma, Via Antonino Pio, 12 Marzo 1958”. Un Cuor Solo, un'Anima Sola, op. cit., p. 204.

${ }^{130}$ NUNES, Maria José Rosado. "Freiras no Brasil". In: PRIORE, Mary del \& BASSANEZI, Carla (org.). História das Mulheres no Brasil. 7. ed. São Paulo, Contexto, 2004.
} 
No mesmo período, dois acontecimentos marcariam as congregações: os falecimentos de Tecla Merlo, em 1964, e de Tiago Alberione, em 1971. Uma historiadora paulina italiana, Catarina Martini, compreendeu a morte do fundador como o encerramento da "fase fundacional" das Filhas de São Paulo, à qual se seguiria uma fase mais experimental, com mudanças nas formas de convivência cotidiana das irmãs, maior preocupação com a formação intelectual e anseios de modernização nos métodos de editar, imprimir e distribuir ${ }^{131}$.

A ausência das figuras fundadoras não somente abre espaço para as gerações mais jovens - como vimos, Tecla ainda falava em bons e maus livros, como nas primeiras décadas do século - mas, também, desata um laço simbólico com a sede italiana da congregação. É claro que o laço permanece firme e as congregações, unificadas, sob os superiores e superioras gerais eleitos posteriormente - nas primeiras décadas, todos italianos. Porém, considerando se tratar de institutos religiosos, as novas autoridades não exerceriam a mesma espécie de poder que as figuras fundadoras, que não tinham apenas uma direção empresarial, mas também eram e continuam sendo modelos de espiritualidade e ação para seus membros. O falecimento de Tecla e Alberione, portanto, representa um ganho de autonomia por cada editora, isto é, por cada país em que a congregação estava presente. Em especial para a brasileira, a segunda maior editora e comunidade paulina após a italiana.

O período marca também uma profissionalização das irmãs e das Edições Paulinas. Enquanto os paulinos realizavam formação sacerdotal e acadêmica em teologia - nas primeiras décadas, todos os paulinos eram enviados a Roma para cursar o ensino superior, como vimos no caso de Bernardo Bósio -, nesse momento também as paulinas

\footnotetext{
${ }^{131}$ MARTINI, Catarina A. As Filhas de São Paulo, op. cit., pp. 475-480.
} 
passam a frequentar as universidades, em especial cursos de comunicação ${ }^{132}$, o que não apenas modifica o trabalho editorial como, também, a visão de mundo dessas mulheres. Diferentemente dos paulinos, porém, elas não seriam enviadas à Europa para estudar, mas cursariam universidades brasileiras - de início, principalmente católicas. O maior contato com o "mundo" ainda é simbolizado pelo fim da obrigação de vestir o hábito religioso, o que transformava sua integração social no cotidiano (por exemplo, universitário, ou mesmo nas livrarias).

Há de se levar em conta, também, a mudança geracional pela qual passavam as congregações. Ao longo das décadas, os cargos de decisão, nos primeiros tempos restritos aos paulinos e paulinas vindos da Itália, começam a ser transferidos para os membros brasileiros. Diferentemente de outras congregações mais tradicionais, os ingressantes nas congregações paulinas não provinham das elites. Como já foi apresentado acima, seu cotidiano não se restringia a estudos e orações, mas também ao trabalho, inclusive ao trabalho operário, por exemplo nas tipografias e gráficas. Portanto, as "matrizes sociais" ${ }^{133}$ dos paulinos e paulinas eram, em relação às outras congregações, bastante particulares.

A irmã paulina Vera Ivanise Bombonatto relatou que, em meados da década de 1970, quando estava realizando seus estudos - ela se formou em Filosofia na Faculdade Dom Bosco, em 1977 - passou um período em El Salvador, onde teve contato com a Igreja local, que, em sua visão, desenvolvia um trabalho excelente ${ }^{134}$. El Salvador passava por sucessivas ditaduras militares, e a Igreja - sobretudo com as reformas pastorais (como o incentivo às comunidades eclesiais de base), empreendidas pelo arcebispo Luis Chávez

\footnotetext{
${ }^{132}$ Esse movimento foi observado por MONTERO, Paula. "O Papel das Editoras Católicas na Formação Cultural Brasileira”. In: SANCHIS, Pierre (org.). Catolicismo: Modernidade e Tradição. São Paulo, Loyola, 1992.

${ }^{133}$ É a categoria utilizada por Sergio Miceli ao estudar a origem social dos bispos brasileiros da Primeira República (MICELI, Sergio. A Elite Eclesiástica Brasileira. Rio de Janeiro, Bertrand, 1988).

${ }^{134}$ Depoimento de Vera Ivanise Bombonatto, 12.4.2019.
} 
y González na esteira do Concílio Vaticano II, e pela atuação de religiosos como Jon Sobrino e Rutílio Grande García - tornava-se uma instituição fundamental na oposição política e na defesa dos direitos humanos ${ }^{135}$.

A atuação de setores da Igreja Católica contra as ditaduras militares e na defesa de maior justiça social espalhava-se pela América Latina. Em 1968, três anos após o encerramento do Concílio Vaticano II, o Conselho Episcopal Latino-Americano (Celam) realiza sua segunda conferência (a primeira ocorrera em 1955, ano de fundação do Conselho, no Rio de Janeiro), em Medellín, na Colômbia. As conclusões foram publicadas em um documento intitulado Presença da Igreja na Atual Transformação da América Latina à Luz do Concílio Vaticano II, que dava outra interpretação à tradição da chamada Doutrina Social da Igreja.

A composição formal da Doutrina Social da Igreja remontava a 1891, quando o papa Leão XIII, buscando oferecer uma resposta amena (e, sobretudo, não socialista) às contradições do mundo industrial, publica a encíclica Rerum Novarum, Sobre a Condição dos Operários. Nela, o papa pregava uma "conciliação de classes"; condenava o comunismo; defendia leis e atuação rígida do Estado para proibir greves; e afirmava ser a propriedade privada "sancionada pelas leis humanas e divinas" e que, sem a desigualdade, "uma sociedade não pode existir nem conceber-se"136. Ainda assim, Leão XIII também reconhecia no trabalho operário, “dos campos ou da oficina”, a "fonte única de onde procede a riqueza das nações"; que muitas das greves ocorriam por conta da exploração; que os salários não poderiam ser menores que o necessário à subsistência de

\footnotetext{
${ }^{135}$ Jon Sobrino, nascido na Espanha, foi um dos teóricos expoentes da Teologia da Libertação. Em 1977, o sacerdote Rutílio Grande foi assassinado. Três anos depois, o sucessor de Chávez y González, o arcebispo Óscar Romero, também foi assassinado a tiros, enquanto celebrava uma missa. Sobre a Igreja em El Salvador, ver, entre outros, LÖWY, Michael. The War of Gods. Religion and Politics in Latin America. London/New York, Verso, 1996, pp. 102-107.

${ }^{136}$ LEÃO XIII. Carta Encíclica Rerum Novarum. Sobre a Condição dos Operários. Roma, 15 de maio de 1891.
} 
um operário "sóbrio e honrado"; e, por fim, fazia um convite à organização de associações operárias católicas ${ }^{137}$. Por conter tal diversidade de preceitos já em sua fundação, ao longo do século XX a Doutrina Social da Igreja seria manejada de múltiplas formas.

O Concílio Vaticano II, na Constituição Pastoral Gaudium et Spes, Sobre a Igreja no Mundo Atual, de 1965, assumiria uma postura menos reacionária e mais reformista. As grandes desigualdades econômicas e sociais deveriam ser eliminadas "o mais depressa possível"; era preciso buscar "o caminho do diálogo e da conciliação", mas a greves poderiam constituir "um meio necessário, embora extremo, para defender os próprios direitos e alcançar as justas reivindicações dos trabalhadores"; os operários deveriam ter o direito de livre-associação, "sem risco de represálias" (já não se fala em associações especificamente católicas); e, por fim, afirmava o direito à propriedade privada, ressaltando ser ela, porém, "de índole social, fundada na lei do destino comum dos bens", condenando a existência de latifúndios improdutivos, "enquanto a maior parte do povo não tem terras ou apenas possui pequenos campos"138.

Três anos depois do Concílio, a Conferência de Medellín afirma que "o Episcopado latino-americano não pode ficar indiferente ante as tremendas injustiças sociais existentes na América Latina, que mantêm a maioria de nossos povos numa dolorosa pobreza, que em muitos casos chega a ser miséria desumana"139. Assim, os bispos, em Medellín, tomam o que ficou reconhecido como "opção preferencial pelos

\footnotetext{
${ }^{137}$ Idem.

138 PAULO VI. Constituição Pastoral Gaudium et Spes. Sobre a Igreja no Mundo Atual. Roma, 7 de dezembro de 1965. O documento é assinado por Paulo VI, mas foi promulgado por votação, após inúmeros debates e discordâncias, entre os participantes do Concílio (cf. SOUZA, Ney de. "Contexto e Desenvolvimento Histórico do Concílio Vaticano II”. In: GONÇALVES, Paulo Sérgio Lopes \& BOMBONATTO, Vera Ivanise (org.). Concílio Vaticano II: Análise e Prospectivas. São Paulo, Paulinas, 2004, pp. 63-64).

${ }^{139}$ Conselho Episcopal Latino-Americano. Presença da Igreja na Atual Transformação da América Latina à Luz do Concílio Vaticano II. Conclusões da II Conferência Geral do Episcopado Latino-Americano. Medellín, 1968, XIV, a.
} 
pobres", o que incluía não apenas o trabalho de evangelização, que deveria priorizá-los ${ }^{140}$, mas também o combate às "injustiças". Na seção "Empresas e Economia", o documento da Conferência defendia que:

A empresa, numa economia verdadeiramente humana, não se identifica com os donos do capital, porque é fundamentalmente uma comunidade de pessoas e unidade de trabalho que necessita de capital para a produção de bens. Uma pessoa ou um grupo de pessoas não podem ser propriedade de um indivíduo, de uma sociedade ou do Estado. O sistema liberal capitalista e a tentação do sistema marxista, pareceriam esgotar em nosso continente, as possibilidades de transformar as estruturas econômicas. Ambos sistemas atentam contra a dignidade da pessoa humana; um porque tem como pressuposto a primazia do capital, seu poder e sua discriminatória utilização em função do lucro. O outro, embora ideologicamente defenda um humanismo, vislumbra melhor o homem coletivo e na prática se transforma numa concentração totalitária do poder do Estado. Devemos denunciar que a América Latina se encontra fechada entre essas duas opções e permanece dependente dos centros de poder que canalizam sua economia ${ }^{141}$.

A América Latina vivia o auge da Guerra Fria, acirrada com o êxito da Revolução

Cubana e com seu alinhamento à União Soviética. Embora se recusasse, como instituição, a assumir esse lado do conflito com uma posição anticapitalista, a Igreja se vê impedida de ignorar os embates sociais. Mesmo porque grande parte de seus membros notáveis atuavam em áreas cuja violência política tornava-se insustentável, fosse nos conflitos rurais, fosse pela própria violência do Estado - as conclusões da conferência latinoamericana criticam, por exemplo, as forças armadas, que deveriam "garantir as liberdades políticas dos cidadãos, em vez de lhes pôr obstáculos"142.

\footnotetext{
${ }^{140}$ Sem deixar de lado o que o documento chama de "pastoral das elites", que incluiria "os artistas, homens de letras e universitários (professores e estudantes); a elite profissional: os médicos, os advogados, educadores (profissões liberais); engenheiros, agrônomos, planificadores, economistas, sociólogos, técnicos em comunicação social (tecnólogos); a elite econômico-social: os industriais, banqueiros, líderes sindicais (operários e camponeses), empresários, comerciantes, fazendeiros...; a elite dos poderes políticos e militares: os políticos, os que exercem o poder judiciário, os militares...” (Idem, VII, 1, b).

${ }^{141}$ Idem, I, 3, c.

${ }^{142}$ Idem, VII, 3, b, 4.
} 
Na prática, Medellín viria legitimar a uma série de movimentos que vinham ocorrendo nos últimos anos. No Brasil, algumas das primeiras organizações católicas a se aproximarem da esquerda foram as seções de juventude da Ação Católica Especializada $^{143}$, em especial a JOC, Juventude Operária Católica ${ }^{144}$, e a JUC, Juventude Universitária Católica - das fileiras desta última, por exemplo, sairiam os fundadores da Ação Popular ${ }^{145}$. Com o acirramento da repressão ditatorial no Brasil, diversos movimentos católicos se expandiriam e se tornariam instâncias importantes de oposição.

Mais do que isso, nos anos que seguiram à Conferência de Medellín, a aproximação com movimentos sociais mais ou menos ligados à esquerda começava a ganhar uma elaboração também teórica, isto é, teológica, na chamada Teologia da Libertação. Nela, a "libertação" não se restringia à alma, mas também abarcava a libertação terrena dos homens face às injustiças sociais. Uma boa síntese se encontra em Jesus Cristo Libertador: Ensaio de Cristologia Crítica para o Nosso Tempo. Nessa coletânea de artigos de 1971, publicada em livro pela Vozes no ano seguinte, Leonardo Boff elenca cinco princípios que deveriam guiar uma "nova cristologia latino-americana". São eles: a primazia do antropológico sobre o eclesiológico; do utópico sobre o factual; do crítico sobre o dogmático; do social sobre o pessoal; e, por fim, da ortopraxia sobre a ortodoxia $^{146}$. Vista com censura pelos mais conservadores, que a consideravam

\footnotetext{
${ }^{143}$ As seções da Juventude Católica se organizavam sob as siglas JAC, JEC, JIC, JOC e JUC, respectivamente, agrária, estudantil, independente, operária e universitária.

${ }^{144}$ Ver, entre outros, o capítulo de MAINWARING, Scott. "A Juventude Operária Católica, 1947-1970". A Igreja Católica e a Política no Brasil (1916-1985). São Paulo, Brasiliense, 2004 [1989], pp. 139-165.

${ }^{145}$ Para um relato de alguns dos fundadores, ver LIMA, Haroldo \& ARANTES, Aldo. História da Ação Popular: da JUC ao PCdoB. 2. ed. São Paulo, Alfa-Omega, 1984, em especial o capítulo III, "A Participação Política dos Cristãos e a JUC", pp. 25-32. Ver, também, GORENDER, Jacob. "As Outras Esquerdas". Combate nas Trevas. A Esquerda Brasileira: das Ilusões Perdidas à Luta Armada. 5. ed. São Paulo, Expressão Popular/Fundação Perseu Abramo, 2014, pp. 39-46.

${ }_{146}$ BOFF, Leonardo. Jesus Cristo Libertador: Ensaio de Cristologia Crítica para o Nosso Tempo. Petrópolis, Vozes, 2012 [1972], pp. 265-269.
} 
marxista $^{147}$, ainda assim essa corrente teológica e, sobretudo, pastoral, ganhava terreno. Em especial, no mundo editorial - e não apenas no católico.

Experiências como a de Vera Bombonatto em El Salvador revelam que, ao buscar uma maior inserção no mundo, as religiosas começam a se defrontar também com outros problemas que transbordavam o trabalho de evangelização e catequese - e o mesmo, é claro, se dava com os paulinos. Nesse período, as congregações e Edições Paulinas começam a estabelecer relações com outros setores e movimentos, que não apenas os círculos intelectuais conservadores de até então. Para além das reformas religiosas, a própria consolidação da empresa contribuía para que os editores e editoras ganhassem maior autonomia.

Conforme afirmou Maria José Rosado Nunes em relação às congregações de “vida ativa", isto é, que realizam trabalhos em áreas como educação, saúde e, em nosso caso, comunicação, em oposição às de "vida contemplativa":

Os recursos advindos das próprias obras, especialmente dos colégios, das doações de particulares, de incentivos governamentais, na forma de não pagamento de impostos e de benefícios suplementares, garantiam às ordens religiosas um certo suporte financeiro, com o qual desenvolveram projetos próprios. [...] Sua dinâmica de expansão e de afirmação institucional lhes permitia ter uma relativa autonomia em face das Igrejas locais ${ }^{148}$.

Embora Rosado Nunes se refira às freiras, isto ocorreu também com a seção administrada pelos homens, no caso das congregações paulinas. Se nos primeiros anos os

\footnotetext{
${ }^{147}$ Embora não fosse marxista, a Teologia da Libertação fazia uso de muitas de suas categorias de análise da sociedade. Para além da influência do próprio pensamento universitário, em especial o latino-americano, havia também muita proximidade com a teologia europeia, em especial a alemã e a francesa. O jesuíta JeanYves Calvez, por exemplo, publicou, em 1956, La Pensée de Karl Marx, que, se por um lado era crítico ao marxismo, por outro, fazia longas análises e definições de conceitos como luta de classes, ideologia, alienação e revolução, o que colocava seminaristas e universitários de teologia em contato com o pensador alemão de uma forma mais ponderada do que faziam os tradicionais panfletos e livros anticomunistas. A primeira edição francesa, de 1956, foi realizada em Paris pela Éditions du Seuil, com Nihil Obstat e Imprimatur da Companhia de Jesus. Em 1958, foi traduzido para o espanhol pela Taurus, de Madrid e, em 1966, para o Italiano, pela Borla, de Roma. Não foram encontradas edições em português.

148 NUNES, Maria José Rosado. "Freiras no Brasil", op. cit.
} 
paulinos ordenados precisaram assumir paróquias, conforme seu trabalho editorial foi sendo reconhecido pela Igreja eles puderam se dedicar somente a essa função, o que os torna, nesse sentido, análogos às paulinas, isto é, uma congregação totalmente dedicada a uma obra específica, podendo exercer em tempo integral sua "missão", seu "carisma". Como abordaremos no capítulo seguinte, em 1973 as duas seções da editora passam a trabalhar diretamente com a Conferência Nacional dos Bispos do Brasil, a CNBB.

Assim, a acumulação de um capital simbólico, cultural e econômico pela empresa é também um fator de autonomia editorial. Quanto a este último, uma das mais importantes fontes de recurso era o folheto $O$ Domingo, que, por trazer o roteiro da missa para acompanhamento dos que a assistiam, teve uma função importante após a reforma litúrgica empreendida pelo Concílio Vaticano II, quando se passa a usar o vernáculo ao invés do latim nas celebrações e a se esperar uma participação mais ativa dos fiéis. De acordo com o padre e editor paulino Claudiano dos Santos, por décadas foram as receitas de $O$ Domingo que financiaram a editora ${ }^{149}$. Se as paulinas tinham uma publicação equivalente, esta poderia ser a revista Família Cristã, mas sua distribuição era muito reduzida se comparada à de $O$ Domingo, cujas assinaturas eram realizadas em escala pelas paróquias, como comentado na seção anterior. Em 1973, quando o paulino Virgílio Ciaccio assume a redação de $O$ Domingo, o periódico passa a ser um suporte de oposição à ditadura militar e, por sua ampla distribuição, alvo recorrente da repressão.

Na década de 1970, as transformações na editora se davam de forma mais acelerada. Como buscamos demonstrar nas páginas acima, a consolidação financeira, o reconhecimento religioso, intelectual e comercial, a profissionalização e as renovações com as reformas, sobretudo após a morte de Alberione e Merlo, e com a mudança geracional dos editores - foram alguns dos processos ocorridos até ali. Porém, as

\footnotetext{
${ }^{149}$ Depoimento de Claudiano Avelino dos Santos, 1.4.2019.
} 
mudanças não se restringiam a fatores internos à editora. Além da Conferência de Medellín, de 1968, outros eventos ocorridos nas décadas de 1960 e 1970 transformaram profundamente a Igreja Católica. O Concílio Vaticano II teve repercussões também na forma como a Igreja lidava com as comunicações e com a cultura. Essas repercussões, aliadas a uma conjuntura política e social conflituosa, tiveram impacto significativo na cúpula do catolicismo brasileiro. No capítulo seguinte, veremos alguns momentos decisivos dessas reformas. 


\title{
Capítulo 2
}

\section{A Igreja e a Comunicação após o Concílio Vaticano II}

\author{
L'équivalent de "Dieu est avec nous", c'est \\ aujourd'hui "l'opinion publique est avec nous". \\ Pierre Bourdieu, "L’Opinion Publique n’Existe pas"150
}

\section{1. "Entre as Maravilhosas Invenções da Técnica": o Concílio Vaticano II}

Em 1961, o papa João XXIII convocou bispos e outros membros da Igreja Católica para a realização de um segundo Concílio em Roma. Iniciado em 1962, os encontros se estenderam até $1965^{151}$. A essa altura, João XXIII falecera e seu sucessor, o também italiano Paulo VI, dera continuidade ao encontro.

De início, esperava-se que a nova reunião seguisse rumos conservadores, afinal, o concílio oitocentista apenas endurecera as determinações elaboradas em Trento, no século XVI. Mas João XXIII conclamava a um aggiornamento, sugerindo o propósito de trazer a Igreja ao dia presente, atualizá-la. Embora as mudanças tenham se mantido dentro dos limites do conservadorismo católico ${ }^{152}$, sobretudo em alguns aspectos mais contrastantes com a esfera secular, como na questão das mulheres ${ }^{153}$, o Concílio alterou

\footnotetext{
150 “O equivalente atual de 'Deus está conosco' é ‘a opinião pública está conosco"” (Les Temps Modernes, n. 318, pp. 1292-1309, 1973).

${ }^{151}$ O Concílio se realizou em quatro fases: $1^{\text {a }}$ ) 11 de outubro a 8 de dezembro de $1962 ; 2^{\mathrm{a}}$ ) 29 de setembro a 4 de dezembro de 1963 (dia em que é decretado o Inter Mirifica); $3^{\text {a }}$ ) 14 de setembro a 21 de novembro de $1964 ; 4^{\text {a }}$ ) 14 de setembro a 8 de dezembro de 1965 (SOUZA, Ney de. "Contexto e Desenvolvimento Histórico do Concílio Vaticano II", op. cit., pp. 17-67).

${ }^{152} \mathrm{O}$ Concílio ressoa muito mais fortemente dentro da Igreja que na sociedade como um todo. O historiador Josep Fontana, por exemplo, considerando sobretudo os aspectos políticos da Igreja, com o conservadorismo posterior de João Paulo II e mesmo de Paulo VI, considera o Concílio um "suposto" aggiornamento (FONTANA, Josep. El Siglo de la Revolución. Una Historia del Mundo desde 1914. Barcelona, Crítica, 2017, p. 377).

153 As mulheres não tiveram sua condição alterada na Igreja, tampouco participaram de forma ativa do Concílio. Após muitos confrontos - os bispos mais contrários justificavam, citando a primeira carta de Paulo aos coríntios, que "estejam caladas as mulheres nas assembleias, pois não lhes é permitido tomar a
} 
significativamente alguns posicionamentos eclesiásticos. Além da principal e mais visível reforma, a litúrgica, que determinou a utilização do vernáculo ao invés do latim nas missas, é a respeito da forma da Igreja lidar com o mundo e a cultura ao seu redor que as decisões conciliares mais interessam a este trabalho.

No Capítulo 1, comentamos que a Constituição Pastoral Gaudium et Spes, Sobre a Igreja no Mundo Atual, de 1965, configura uma nova abordagem da Doutrina Social da Igreja, com posições mais progressistas (relativamente, isto é, quando comparadas à própria tradição católica) quanto à vida econômica e social. Mas o escopo do documento era mais amplo. Estabelecia também princípios gerais sobre como a Igreja deveria se relacionar com o mundo em que estava inserida, em especial com a cultura de seu tempo. O diálogo entre a fé e a cultura, não a negação e condenação desta última, é uma das leituras católicas ${ }^{154}$ para a definição de cultura presente no Gaudium et Spes, como "um meio definido e histórico, no qual é inserido o homem de qualquer nação ou tempo e de onde ele tira os bens para promover a civilização humana"155.

Nas palavras de Luiz Roberto Benedetti, antes do Concílio a Igreja pretendia “proteger o cristão contra o mundo". Depois, ela busca "preparar o cristão para lançá-lo em meio ao mundo"156. Como vimos, até então as principais obras da imprensa católica consistiam em publicações de cunho moralizante, de combate à "má imprensa". O que

palavra" (1 Coríntios 14:34) - 23 mulheres são autorizadas como "auditoras" a partir da terceira sessão do Concílio, mas sem o direito de fazer uso da palavra. Neste momento, havia mais de um milhão de religiosas na Igreja Católica, sem contar as leigas (VALERIO, Adriana. A Presença Feminina no Vaticano II. As 23 Mulheres do Concílio. São Paulo, Paulinas, 2014, pp. 42-47).

${ }^{154}$ Cf. ANDRADE, Paulo Fernando Carneiro de. "A Educação do Ser Humano Realizada no Diálogo entre Fé e Cultura. A Contribuição do Concílio Vaticano II". In: GONÇALVES, Paulo Sérgio Lopes \& BOMBONATTO, Vera Ivanise (org.). Concílio Vaticano II: Análise e Prospectivas, op. cit. Ver também PUNTEL, Joana. Pastoral da Comunicação: Diálogo entre Fé e Cultura. São Paulo, Paulinas, 2007.

155 PAULO VI. Constituição Pastoral Gaudium et Spes. Sobre a Igreja no Mundo Atual. Roma, 7 de dezembro de 1965.

${ }^{156}$ BENEDETTI, Luiz Roberto. Templo, Praça, Coração: A Articulação do Campo Religioso Católico. São Paulo, Humanitas, 2000, p. 65. 
também acontecia em relação a outras mídias, como o cinema, que levava instituições como as congregações paulinas a avaliar os filmes de acordo com critérios religiosos.

A suspeição da Igreja Católica para com a cultura secular se intensificara desde o século XVI, com o Concílio de Trento. O Index Librorum Prohibitorum e a Congregação do Índice, que o organizava, foram estabelecidos contemporaneamente à Inquisição e ao período de multiplicação de livros impressos pela técnica de Gutenberg. Já no século XX, sua publicação é transferida por Pio XII ao controle direto da Congregação do Santo Ofício (até 1908, chamada de Inquisição Universal), que produz uma última edição do índice em 1948 ${ }^{157}$. Em 1965, no penúltimo dia do Concílio Vaticano II, Paulo VI decreta uma reforma no órgão do Santo Ofício, alterando mais uma vez seu nome, desta vez para Congregação para a Doutrina da Fé. A Congregação iria manter sua função de corrigir "erros", ainda que Paulo VI afirmasse que "suavemente"158. Os quadros do órgão continuavam os mesmos, tradicionalmente filiados às alas conservadoras da Igreja.

A verdadeira novidade vinha como consequência dessa reforma: em 1966, o Index foi abolido. A Congregação declara então que "tal Índice não tem valor de lei eclesiástica com as censuras que o acompanhavam" "159. Mas, sem jogar por terra a publicação, reforça que "o Índice conserva sua força moral, enquanto adverte a consciência dos fiéis que, por exigir-lhe o direito natural, abstenham-se de ler aqueles escritos que possam prejudicar a fé e os bons costumes" e, ao pé da página, informa que o documento foi assinado em "Roma, na sede do Santo Ofício"160. Embora as decisões saídas do Vaticano II visassem

\footnotetext{
157 BUJANDA, Jésus Martínez de \& RICHTER, Marcella. Index Librorum Prohibitorum 1600-1966. Montréal, Médiaspaul, 2002, pp. 27-44. A citação enseja um comentário: a Médiaspaul é a atual editora dos paulinos na região do Quebec, Canadá, e publica obras em francês.

158 PAULO VI. Carta Apostólica Motu Proprio Integrae Servandae. Roma, 7 de dezembro de 1965.

${ }^{159}$ CONGREGAÇÃO PARA A DOUTRINA DA FÉ. Notificação sobre a Situação do Índice de Livros Proibidos. Roma, 14 de junho de 1966. A notificação é assinada pelo prefeito da congregação, o cardeal Alfredo Ottaviani, e pelo secretário, Pietro Parente.

${ }^{160}$ Idem.
} 
colocar "um fim ao espírito do Index"161, está claro que alguns setores aceitavam as mudanças um pouco a contragosto. Pelo menos entre os herdeiros do Santo Ofício, o espírito do Index ainda continuaria presente, como demonstrariam as condenações à Teologia da Libertação nos anos 1980.

De qualquer forma, agora, após as reformas da década de 1960, a comunicação terá outro papel no mundo católico. Embora não abandone seu caráter moralizante e dogmático, a ênfase deveria recair sobre o aspecto "pastoral", positivo, e mesmo, diríamos, publicitário, esse último termo, todavia, ausente dos discursos oficiais.

A cultura de massa, crescentemente secular, se consolidava e dominava os "modernos" meios de comunicação, dos quais a Igreja estava praticamente excluída. Por conseguinte, a instituição se fazia ausente não apenas da vida pública, mas também, e cada vez mais, da vida íntima e doméstica das famílias e indivíduos, que tinham mais contato com a imprensa, o rádio, o cinema e, agora também, a televisão, do que com a religião, ao menos em sua forma institucional. Não surpreende, portanto, que a comunicação católica fosse estimulada com sentido de urgência. As editoras, inclusive.

Em 1967, as Edições Paulinas publicaram no Brasil Apostolado da Edição, de Tiago Alberione. Mas, nessa tradução, o livro trazia um subtítulo atualizado: Apostolado da Edição, Ou Apostolado dos Meios de Comunicação. Desde 1963, ainda durante a realização do Concílio Vaticano II, o termo “comunicação" se fazia presente no ambiente eclesiástico, tendo aparecido primeiro no decreto Inter Mirifica ${ }^{162}$ de Paulo VI. Não é nosso intuito analisar as diretrizes oficiais vaticanas para a comunicação, tema que já foi amplamente estudado na academia, sobretudo por autores ligados à Igreja - o que aponta para um esforço no sentido de fazer valer, na comunicação da Igreja brasileira, as

\footnotetext{
${ }^{161}$ BUJANDA, Jésus Martínez de \& RICHTER, Marcella. Index Librorum Prohibitorum 1600-1966, op. cit., p. 44.

162 "Inter mirifica technicae artis inventa...", isto é, "entre as maravilhosas invenções da técnica...". PAULO VI. Decreto Inter Mirifica sobre os Meios de Comunicação Social. Vaticano, 4 de dezembro de 1963.
} 
orientações romanas ${ }^{163}$. No entanto, pela repercussão e influência do Concílio Vaticano II na edição dos livros católicos, incentivando-os e ampliando seu escopo, é indispensável apresentar brevemente alguns pontos específicos ali estabelecidos.

No Inter Mirifica expunha-se a necessidade de "formar e divulgar uma reta opinião pública", pois ela "exerce hoje uma poderosa influência em todas as ordens da vida social, pública e privada" 164 . No ano seguinte, 1964, seria criado por determinação do Inter Mirifica de Paulo VI o Pontifício Conselho para as Comunicações Sociais. A instituição de um dicastério ${ }^{165}$ para as comunicações havia sido proposta por vários participantes do Concílio, inclusive Tiago Alberione. Para este, um setor da Santa Sé dedicado apenas a essa questão poderia dar "direção, impulso e coordenação aos meios [de comunicação]"166.

Em 1971, esse Pontifício Conselho publicaria um novo texto bastante significativo, aprofundando a abordagem do decreto. Também afirmando ser "essencial o desenvolvimento da opinião pública na Igreja", a instrução pastoral Communio et Progressio, “comunhão e progresso", trazia orientações mais específicas e direcionadas. Entre outras, sobre os livros:

Multiplicam-se, nos nossos dias, edições de divulgação, livros de bolso, que, pondo à disposição do público clássicos de literatura religiosa, obras primas de todas as nações, obras de carácter técnico e científico, proporcionam leituras agradáveis e proveitosas. Também os "livros de quadradinhos" [i.e. quadrinhos] e narrações ilustradas se têm

\footnotetext{
${ }^{163}$ Para o Brasil, ver, entre outros, DELLA CAVA, Ralph \& MONTERO, Paula. E o Verbo se Faz Imagem: Igreja Católica e os Meios de Comunicação no Brasil, op. cit. Entre os trabalhos realizados internamente à Igreja Católica, destacam-se principalmente SOARES, Ismar de Oliveira. Do Santo Ofício à Libertação: O Discurso e a Prática do Vaticano e da Igreja Católica no Brasil sobre a Comunicação Social. São Paulo, Edições Paulinas, 1988 (Comunicação Social); PUNTEL, Joana. Igreja e Sociedade: Método de Trabalho na Comunicação. São Paulo, Paulinas, 2015; e, da mesma autora, Comunicação: Diálogo dos Saberes na Cultura Midiática. São Paulo, Paulinas, 2010.

${ }^{164}$ PAULO VI. Decreto Inter Mirifica sobre os Meios de Comunicação Social, op. cit.

${ }^{165}$ Nome dado a cada departamento da Cúria Romana. São dicastérios, por exemplo, as secretarias, tribunais eclesiásticos, comissões etc.

166 Proposta de Tiago Alberione apresentada à comissão pré-conciliar, apud DAMINO, Andrea. Don Alberione al Concilio Vaticano II. Proposte, Interventi e Appunti. II Edizione Corretta ed Accresciuta. Roma, Edizioni dell'Archivio Storico Generale della Famiglia Paolina, 2005, pp. 55-57.
} 
revelado úteis, por exemplo, na explicação da Escritura e da vida dos Santos. Todo este tipo de publicações merecem a nossa atenção e apoio $^{167}$.

O Conselho também convidava os católicos a lerem regularmente as publicações católicas, "contanto que dignas deste nome", "não somente para colherem informações religiosas, mas também para, através dos comentários lidos, olharem os acontecimentos do mundo com uma mentalidade cristã"168 e pregava "a liberdade de expressão", mas "dentro dos limites da moralidade e do bem comum" 169 .

Na instrução de 1971, a Igreja fala pela primeira vez em mass media, meios de comunicação de massa, e estimula sua ampla utilização. Reconhece, também, a necessidade de profissionalização: quem trabalhasse no "campo das comunicações" deveria "procurar a especialização teórica e prática correspondente e, mesmo, obter os graus acadêmicos das faculdades de meios de comunicação"170. Como abordado no Capítulo 1, foi justamente este o caminho seguido pelas paulinas.

Paulo VI, em 1969, discursou na abertura do II Capítulo Geral da Pia Sociedade de São Paulo. Entre homenagens a Alberione, à congregação e à “família paulina” como um todo - que compreendia, entre outras, também as Filhas de São Paulo -, o papa dava "reconhecimento, elogio e encorajamento" à "capilaridade" geográfica da obra de "comunicação social" levada a cabo por aqueles religiosos, obra que realizava "ante et post litteram" os postulados do Concílio Vaticano II para as comunicações ${ }^{171}$. Isto é, Paulo VI afirma que as congregações paulinas já colocavam em prática o aggiornamento antes mesmo desses postulados serem estabelecidos textualmente. Não se trata de um

\footnotetext{
${ }^{167}$ PONTIFÍCIO CONSELHO PARA AS COMUNICAÇÕES SOCIAIS. Instrução Pastoral Communio et Progressio sobre os Meios de Comunicação Social Publicada por Mandato do Concilio Ecuménico II do Vaticano. Roma, 23 de maio de 1971.

168 Idem.

${ }^{169}$ Idem.

${ }^{170}$ Idem.

${ }^{171}$ PAULO VI. Discorso ai Partecipanti al Capitolo Generale della Pia Società San Paolo. Ariccia, 28 de junho de 1969.
} 
pioneirismo, mas de considerar, também, que as reformas conciliares foram tomadas de maneira "coletiva", isto é, com participação de muitos líderes (homens) da Igreja, sob a forma de sugestões, assembleias, discussões e votações. Portanto, o que muitas instituições já realizavam foi incorporado pelo Concílio.

Em escrito de 1953, Alberione afirmava que a tarefa das congregações paulinas deveria ser a "animação cristã da cultura". O superior-geral fornecia "orientações" gerais às edições:

Oferecer em primeiro lugar a doutrina que salva. Impregnar de Evangelho todo o pensamento e a ciência humana. Não tratar somente de religião, mas falar de tudo cristãmente; à semelhança de uma universidade católica que, se for completa, leciona teologia, filosofia, letras, medicina, economia política, ciências naturais etc., tudo, entretanto apresentado de maneira cristã, e tudo orientado para o catolicismo $^{172}$.

Nesse sentido, publicar temáticas tão variadas não representava apenas uma “abertura ao mundo", como se afirmaria após o Concílio, mas, também, o anseio de, ao se inserir na cultura, cristianizá-la. Dito de outra forma, por que os católicos deveriam relegar ao mundo laico a tarefa de discutir, por exemplo, a política, se, "abrindo-se" para ela, trariam-na também para a esfera católica? Lembre-se que o próprio Alberione participaria do Concílio, em especial das discussões a respeito da comunicação ${ }^{173}$. Assim, de alguma forma, os objetivos de Alberione e de outros líderes da comunicação católica também pesaram nas decisões conciliares.

A novidade prática do Concílio, quanto à problemática que mais nos interessa, está no desejo de sistematização e expansão da comunicação católica, até então uma questão marginal, restrita ao incentivo a iniciativas mais ou menos pontuais, como foram

\footnotetext{
${ }^{172}$ ALBERIONE, Tiago. Abundantes Divitiae Gratiae Suae. História Carismática da Família Paulina, op. cit., pp. 55-56.

${ }^{173}$ AMINO, Andrea. Don Alberione al Concilio Vaticano II. Proposte, Interventi e Appunti, op. cit.
} 
as da "boa imprensa" no início do século. Para a concretização dessa nova perspectiva, além do Conselho Pontifício, deveriam constituir-se os secretariados nacionais, sempre sob o comando de autoridades eclesiásticas.

Se, por um lado, a Igreja Católica nunca esteve à parte das demais esferas da sociedade - econômica, política, cultural - por outro, caracteriza-se pela tradição e a resistência às transformações. O Concílio Vaticano II representa o momento em que a Igreja, como instituição, percebeu o quanto lhe era prejudicial negar, de forma declarada, a modernidade. Por mais que as reformas da década de 1960 sejam, ao observador externo, ínfimas, é na própria ideia de reforma que se encontra o significado do Concílio. Isto é, apresentar-se como renovada, como inserida no mundo, já acarreta uma transformação na visão que seus membros e a sociedade possuem da instituição. Assim, aqueles com anseios de reforma mais amplos sentem-se apoiados pelo Concílio e, excetuando os excepcionalmente tradicionalistas ${ }^{174}$, a maior parte da Igreja o encara de forma positiva, como moderado e benéfico, e busca seguir suas determinações. Foi este o caso da Igreja no Brasil.

\subsection{A CNBB: Política e Edição}

Pierre Bourdieu e Monique de Saint-Martin, ao estudarem o corpo episcopal francês em fins do século XX, identificaram nele um setor orientado ao "exercício do poder e dos prestígios externos dos porta-vozes" ${ }^{\prime 75}$. No Brasil, o exercício do poder e o prestígio dos bispos foram incrementados pela criação da Conferência Nacional dos Bispos do Brasil (CNBB) em 1952. A partir de então, este corpo episcopal se fortalece ao

\footnotetext{
${ }^{174}$ Essas alas buscam, ainda hoje, ignorar a existência do Concílio Vaticano II, a que muitas chamam de "herege", e privilegiam as determinações do Concílio de Trento, ocorrido no século XVI. No Brasil da ditadura militar, destacava-se a TFP, Tradição, Família e Propriedade, mas não se resumia a esta.

${ }^{175}$ BOURDIEU, Pierre \& SAINT-MARTIN, Monique de. "La Sainte Famille. L'Épiscopat Français dans le Champ du Pouvoir". Actes de la Recherche en Sciences Sociales, vol. 44-45, 1982, p. 29.
} 
formar um coletivo, a instituição mais próxima do que se poderia chamar de representante da Igreja Católica "brasileira".

A organização dos bispos na CNBB foi o ponto culminante de um longo processo de investimentos na estrutura eclesiástica, estabelecimento de numerosas novas dioceses e esforços conjuntos de profissionalização dos altos quadros católicos, processo iniciado ainda na Primeira República ${ }^{176}$. O nome dado à Conferência, "Bispos do Brasil" referese aos bispos e arcebispos que comandam dioceses e arquidioceses no país. A arquidiocese é a sede da província eclesiástica, esta última formada por um grupo de dioceses vizinhas. Dez anos depois de sua fundação, a CNBB realiza sua V Assembleia Geral, em abril de 1962, quando são criados também os chamados Regionais, que agregam os bispos de uma ou mais província eclesiástica - por exemplo, o Regional Sul 1 refere-se ao estado de São Paulo, que até 1992 era dividido em cinco províncias eclesiásticas (São Paulo, Botucatu, Campinas, Ribeirão Preto e Aparecida); já o Regional Nordeste 1 abrange o Ceará, que possui apenas a província eclesiástica de Fortaleza. Até 1989, a província eclesiástica de São Paulo englobava, além da Arquidiocese de São Paulo, as dioceses de Mogi das Cruzes, Santo André, Santos e Guarulhos (esta última criada apenas em 1981). Depois daquele ano, a Arquidiocese perde grande parte de seu terreno com a criação das dioceses de Osasco, Campo Limpo, Santo Amaro e São Miguel Paulista $^{177}$.

Na mesma V Assembleia de 1962 foi produzido o Plano de Emergência para a Igreja do Brasil. O Concílio Vaticano II havia sido convocado em dezembro do ano

\footnotetext{
${ }^{176}$ Cf. MICELI, Sergio. A Elite Eclesiástica Brasileira, op. cit.

177 Sobre o desmembramento da Arquidiocese realizado por João Paulo II em 1989, que gerou inúmeras polêmicas quanto à sua motivação ser ou não política, ver RODRIGUES, Cátia Regina. A Arquidiocese de São Paulo na Gestão de D. Paulo Evaristo Arns (1970-1990). Dissertação de Mestrado em História Social, Universidade de São Paulo, 2008, especialmente pp. 130-138. A autora aponta que, ao mesmo tempo que Evaristo Arns manifestava intenção de delegar funções e liderar de forma colegial, o papa possuía muitas divergências políticas com ele, e a decisão de fato enfraqueceu sua liderança nos bairros e municípios das novas dioceses, em especial quanto às comunidades eclesiais de base.
} 
anterior, e em outubro próximo seriam iniciados os trabalhos. No mesmo mês da convocação, João XXIII enviara uma carta aos bispos latino-americanos, conclamando-os ao fortalecimento da Igreja no continente ${ }^{178}$. Nesse clima de expectativas e perspectivas de reformas, o Plano de Emergência visava estabelecer uma organização racional de um “renovado esforço de pastoral" para aumentar a "influência real" da Igreja no Brasil ${ }^{179}$.

A fim de combater os "quatro perigos mortais" que atingiam a América Latina (naturalismo, protestantismo, espiritismo e marxismo) ${ }^{180}$ e fortalecer o trabalho pastoral, era necessário "planejamento", palavra-chave do documento. Na avaliação dos bispos, faltava à Igreja no Brasil organização e trabalho conjunto, dos leigos à alta hierarquia. $\mathrm{O}$ trabalho deveria ser realizado em duas linhas, orientação e execução. Sobre a primeira, além de seguir as "diretrizes doutrinárias", urgia compreender a realidade do país e da Igreja de forma "sociológica": para isso, decidiu-se pela criação do Ceris, Centro de Estudos Religiosos e de Investigações Sociais. Já a segunda prática compreendia "renovação paroquial, renovação dos educandários católicos, mobilização total dos apostolados dos leigos e pastoral de conjunto"181.

Assim como o Concílio faria pouco depois, a CNBB já apresentava em 1962 intenções de maior sistematização de sua atividade. Se a atuação dos leigos, sobretudo por meio da Ação Católica Especializada, exigia método, a dos sacerdotes era ainda mais complexa. Os padres deveriam ser, ao mesmo tempo, "adultos" (ter responsabilidade e

\footnotetext{
${ }^{178}$ CNBB. Plano de Emergência para a Igreja do Brasil. 2. ed. São Paulo, Paulinas, 2004, p. 13 [1 $1^{\text {a }}$ ed. Rio de Janeiro, Livraria Dom Bosco Editora, 1963]. João XXIII já havia feito um pronunciamento de mesmo teor à III Reunião do Conselho Episcopal Latino-americano em 1958, duas semanas após ter assumido o cargo pontifício.

179 Idem, p. 15.

${ }^{180}$ Idem, p. 19. Algumas páginas depois criticavam o liberalismo: “Os problemas sociais estão na ordem do dia. A missão de Pastores pede dos Bispos uma atenção especial neste campo, abrangendo todos os seus aspectos. Somos solícitos no combate ao Comunismo, mas nem sempre assumimos a mesma atitude diante do capitalismo liberal. Sabemos ver a ditadura do Estado marxista, mas nem sempre sentimos a ditadura esmagadora do econômico ou do egoísmo nas estruturas atuais que esterilizam nossos esforços de cristianização" (Idem, p. 23). A crítica geral se fazia contra o "materialismo", na linha da Doutrina Social da Igreja, cuja base era a Rerum Novarum de 1891, conforme comentado acima, no Capítulo 1.

${ }^{181}$ Idem, p. 27.
} 
obediência), profetas, sacerdotes, ministros e pastores. Este último aspecto era considerado "o mais exigente, mas, talvez, o mais importante e decisivo para a Igreja de hoje". O padre "pastor", isto é, que lidera suas ovelhas,

Sem ser especialista, precisa ter conhecimentos de pedagogia, de psicologia (nas suas diversas divisões), de ciências sociais, de economia, conhecimentos técnicos (conforme o meio em que trabalha), desenvolvimento de comunidade, técnica de liderança, trabalho em grupo, meios de comunicação com a massa e opinião pública, etc. ${ }^{182}$

Mas o padre não precisaria trabalhar sozinho. Na assembleia que deu origem ao Plano de Emergência foi criada também a Comissão Episcopal de Opinião Pública ${ }^{183}$. Seus três membros, os arcebispos Eugênio Sales e Antônio Macedo e o bispo Luiz de Nadal, instituíram em abril de 1963, um ano depois da assembleia, um órgão executivo, o Secretariado Nacional de Opinião Pública ${ }^{184}$. O Inter Mirifica, decreto conciliar que "estabelecia e mandava" a criação de secretariados episcopais nacionais para a área de comunicações, seria publicado apenas em dezembro de 1963. Da criação do Secretariado até 1966, ele foi coordenado pelo padre Waldo Maciel e, a partir de então, pelo frade dominicano Romeu Dale, que ali permaneceria até 1971, quando o órgão passa a se chamar Setor Meios de Comunicação Social e Romeu Dale é substituído pelo então padre e futuro bispo Alfredo Novak, responsável pela Campanha da Fraternidade ${ }^{185}$. Campanha que, nas palavras de Ralph Della Cava, seria a partir da década de 1970 o "maior empreendimento de comunicação" da $\mathrm{CNBB}^{186}$. Mas, de acordo com o mesmo pesquisador, a primeira tarefa do Secretariado Nacional de Opinião Pública havia sido

\footnotetext{
${ }^{182}$ Idem, p. 66, grifos meus.

${ }^{183}$ Idem, p. 25.

${ }^{184}$ ALVARENGA, Ricardo Costa. “A Comunicação da Igreja Católica no Brasil: Criação e Evolução da Comissão Episcopal de Opinião Pública”. Pensacom Brasil, São Paulo, dez. 2017, p. 3.

185 Idem, pp. 3-6.

186 DELLA CAVA, Ralph. “A Conferência Nacional dos Bispos do Brasil e os Meios de Comunicação Social: 1962-1989”. In: DELLA CAVA, Ralph \& MONTERO, Paula. E o Verbo se Faz Imagem: Igreja Católica e os Meios de Comunicação no Brasil, 1962-1989, op. cit., 1991, p. 31.
} 
cobrir o Concílio Vaticano ${ }^{11}{ }^{187}$. Com um correspondente em Roma, o jornalista Otto

Engel, o Secretariado editou o boletim semanal Concílio em Foco,

Enviado a todas as sedes arquidiocesanas, diocesanas e paroquiais, casas religiosas (masculinas e femininas), colégios católicos, A.C. [Ação Católica] e demais grupos de apostolado leigo, publicações e emissoras católicas, numa tiragem de 12.000 exemplares ${ }^{188}$.

A grande tiragem do boletim demonstra o esforço da CNBB em propagar entre a Igreja brasileira o que ocorria no Vaticano. De acordo com Luiz Roberto Benedetti, a própria CNBB se fortalecia com o Concílio, que enfatizava a colegialidade episcopal na Igreja $^{189}$, ao contrário do Vaticano I, cujo destaque era a reafirmação da infalibilidade papal. No encerramento do Concílio Vaticano II, nos últimos meses de 1965, a Conferência promoveu sua vII Assembleia Geral ${ }^{190}$ e preparou um novo documento, o Plano de Pastoral de Conjunto, destinado a organizar os procedimentos eclesiásticos brasileiros pelos próximos quatro anos (1966 a 1970) de acordo com as decisões conciliares.

Publicado em 1966 pela Livraria Dom Bosco Editora, o novo plano era estruturado em torno de seis linhas de trabalho da ação pastoral e quatro programas para as atividades da CNBB. Após a justificativa a cada uma das linhas de trabalho, expunhamse as "atividades-fim" (objetivos) e as "atividades-meio" para alcançá-las. Além da

\footnotetext{
${ }^{187}$ Idem, pp. 24-25.

188 "Relatório do Secretariado Nacional de Opinião Pública à VI Assembleia Ordinária da CNBB, Roma, setembro/outubro de 1964”. Reproduzido por ALVARENGA, Ricardo Costa. A Comunicação da Igreja Católica no Brasil: Tendências Comunicacionais da Conferência Nacional dos Bispos do Brasil. Dissertação de Mestrado em Comunicação Social, Universidade Metodista de São Paulo, São Bernardo do Campo, 2016, p. 204. O boletim foi utilizado como fonte sobre o concílio por José Oscar Beozzo em $A$ Igreja do Brasil no Concílio Vaticano II: 1959-1965. São Paulo, Paulinas, 2005.

${ }^{189}$ BENEDETTI, Luiz Roberto. Templo, Praça, Coração: A Articulação do Campo Religioso Católico, op. cit., p. 42.

190 José Oscar Beozzo afirma que essa assembleia foi organizada às pressas para acompanhar o fim do Concílio (BEOZZO, José Oscar. "A Recepção do Vaticano II na Igreja do Brasil”. In: INSTITUTO NACIONAL DE PASTORAL (org.). Presença Pública da Igreja no Brasil (1952-2002): Jubileu de Ouro da CNBB. São Paulo, Paulinas, 2003).
} 
execução das reformas, as "atividades-meio" de todas as linhas de trabalho incluíam criar uma “opinião pública” favorável em torno delas ${ }^{191}$.

Assim, para a linha de trabalho $\mathrm{n}^{\circ} 1$, "Promover uma sempre mais plena unidade visível no seio da Igreja Católica", a atividade-meio n ${ }^{\mathrm{o}} 12$, em um total de 15 , era "Criar um movimento de opinião pública que apresente uma imagem mais autêntica do laicato, da hierarquia e do estado religioso e sua melhor integração na comunidade de Igreja" ${ }^{192}$. Para a linha de trabalho $\mathrm{n}^{\mathrm{o}}$ 2, "Promover a ação missionária", era preciso "Criar um movimento de opinião pública favorável ao anúncio da mensagem e ao testemunho missionário"193. A mesma fórmula era usada para as outras linhas de trabalho, sendo sempre um meio eficaz "criar um movimento de opinião pública favorável”, fosse à "renovação da catequese e da reflexão teológica"194, à "renovação litúrgica"195 (especialmente aos leigos, a reforma mais visível do Concílio, isto é, que afetava diretamente a forma de rezar a missa) e ao "autêntico ecumenismo"196, além de "criar um movimento de opinião pública que faça todos compreenderem o autêntico papel da Igreja na construção do mundo", a fim de "promover a melhor inserção do povo de Deus, como fermento na construção de um mundo segundo os desígnios de Deus" ${ }^{\text {"197 }}$.

Não bastavam as reformas, era preciso que a opinião pública - um corpo tão místico quanto a Igreja, com a diferença de que esta última possui uma sede central e uma hierarquia mundana - as aceitasse. Nos termos do filósofo alemão Jürgen Habermas, que estudava o conceito de opinião pública nos mesmos anos do Concílio (embora não tenha entrado na questão sobre a Igreja contemporânea), desde fins do século XVIII a ideia de

\footnotetext{
${ }^{191}$ CNBB. Plano de Pastoral de Conjunto 1966-1970. 2. ed. São Paulo, Paulinas, 2004.

192 CNBB. Plano de Pastoral de Conjunto 1966-1970, p. 43.

193 Idem, p. 47.

${ }^{194}$ Idem, p. 50.

195 Idem, p. 56.

${ }^{196}$ Idem, p. 58.

${ }^{197}$ Idem, pp. 59-62.
} 
opinião pública não pode ser separada de seu "instrumento", a imprensa. Esta última contribuiria para a formação de uma opinião crítica, formada na razão. Mas ele destacava outro significado, mais antigo, para "opinião", antes relacionado às aparências que à reflexão: "a reputação, a consideração, aquilo que se apresenta à opinião dos outros. Opinion no sentido de uma opinião incerta, que ainda teria de passar pela prova da verdade, liga-se à opinion no sentido de uma reputação diante da multidão, questionável em seu cerne"198. Quando os bispos falam em "criar um movimento de opinião pública favorável", mesclam os dois significados: reputação perante a sociedade (e não opinião crítica), mas formada com os instrumentos modernos de informação - entre eles, a imprensa.

De volta ao Plano de Pastoral de Conjunto de 1966, vê-se que ele também apresentava quatro programas de atividades da CNBB, que consistiam em "levantamentos e pesquisas" (sobretudo a cargo do Ceris); "reflexão e elaboração teológico-pastoral"; “formação de pessoal", cujo último tópico era "formação da opinião pública", projeto coordenado pelo Secretariado Nacional de Opinião Pública; e "montagem de novos serviços de assessoria", no qual figurava a "reestruturação da Livraria Dom Bosco Editora" para a qual deveria ser feita a "constituição de um fundo de publicação e ampliação dos serviços de venda e divulgação de livros" 199 . O trabalho com a livraria não ficaria a cargo do Secretariado Nacional de Opinião Pública, mas do próprio Secretariado $\mathrm{Geral}^{200}$. A Conferência já havia publicado uma coleção pela editora, Cadernos da CNBB, que não teve longo prosseguimento. Da mesma forma, a reestruturação proposta em 1966 não levou a Dom Bosco - leiga, estampava sua marca como "Um Serviço da Ação

\footnotetext{
${ }^{198}$ HABERMAS, Jürgen. Mudança Estrutural da Esfera Pública. São Paulo, Unesp, 2014, pp. 240-246. A edição original é de 1962.

${ }^{199}$ CNBB. Plano de Pastoral de Conjunto 1966-1970, op. cit., pp. 79-93.

${ }^{200}$ Idem, p. 93.
} 
Católica Brasileira" - muito adiante. Alguns anos depois, a CNBB se aproximaria de outra editora católica já estruturada, as Edições Paulinas.

A partir da década de 1970, membros das congregações paulinas passam a trabalhar nos recém-organizados departamentos de comunicação da CNBB. O padre paulino José Dias Goulart, que havia dirigido o jornal A Imprensa na década de 1950, foi o primeiro assessor de imprensa da CNBB, de 1971 a $1979^{201}$. Já no Setor Meios de Comunicação Social as irmãs paulinas teriam proeminência por vinte anos ininterruptos: em 1972, Maria Dulce ali começa a trabalhar sob a direção de Alfredo Novak ${ }^{202}$. Em 1979, o cargo de Novak é ocupado por Maria da Glória Bordeghini, substituída em 1986 por Maria Alba Vega, que permaneceria até $1991^{203}$. Bordeghini criou no Setor a chamada Equipe de Reflexão, dedicada a estudos e pesquisas teóricas. A primeira reunião da Equipe teria ocorrido na sede da revista Família Cristã, em São Paulo. Já Maria Alba Vega, ao sair do Setor em 1991, assumiria nos próximos oito anos a função de assessora de imprensa da Conferência ${ }^{204}$.

Portanto, entre 1979 e 1991, o órgão mais importante de comunicação da CNBB (e da Igreja no Brasil) foi dirigido por irmãs paulinas, Maria da Glória Bordeghini e Maria Alba Vega. Os projetos de renovação da CNBB no período posterior ao Concílio exortavam a mobilização das religiosas no trabalho "pastoral", complementar às obras específicas de cada congregação. Como observou Maria José Rosado Nunes a respeito dos efeitos do Vaticano II nas congregações femininas, “embora sua inserção social e eclesial continuasse a se realizar, prioritariamente, através do trabalho nas 'obras' das

\footnotetext{
201 ALVARENGA, Ricardo Costa. A Comunicação da Igreja Católica no Brasil, op. cit., pp. 112; 165. 202 MONTERO, Paula. "Letras Católicas na Sociedade de Massas". In: DELLA CAVA, Ralph \& MONTERO, Paula. E o Verbo se Faz Imagem: Igreja Católica e os Meios de Comunicação no Brasil, op. cit., p. 176. Não foram encontradas mais informações sobre Maria Dulce que, ao contrário das sucessoras Bordeghini e Vega, não exerceu cargo de chefia.

203 ALVARENGA, Ricardo Costa. A Comunicação da Igreja Católica no Brasil, op. cit., pp. 119-120.

${ }^{204}$ Idem, pp. 134-137.
} 
congregações, estas reorientaram seu trabalho para o "serviço mais direto da pastoral""205. No caso específico das paulinas (e também, mas em menor grau, dos paulinos), sua experiência com a comunicação capacitava-as a uma participação nos novos órgãos eclesiásticos. Sobre elas, Paula Montero afirmou:

É claro que essa integração progressiva nos órgãos executivos da CNBB e das várias pastorais leva essa congregação a uma posição privilegiada para produzir e distribuir obras imediatamente afinadas com as iniciativas de um episcopado cada vez mais dependente dos meios modernos de divulgação para informar o corpo eclesial e os fiéis das novas campanhas, posicionamentos e mudanças do rumo da Igreja. Participando diretamente do planejamento da ação pastoral, é possível ter, em primeira mão, ideia do que precisa ser publicado e distribuído ${ }^{206}$.

Essa aproximação não se concretizou apenas na participação nos órgãos. A partir da década de 1970, as Edições Paulinas assumiram uma tarefa econômica, simbólica e institucionalmente vantajosa: editar os livros da própria CNBB. Isso foi possível porque a empresa já contava com uma estrutura editorial sólida, da preparação do texto à venda ao leitor, parque gráfico próprio, redes de distribuição e vendas. Além da questão do prestígio religioso, desenvolvido ao longo das décadas, como abordado no Capítulo 1.

A primeira coleção a estreitar as relações entre as Edições Paulinas e a CNBB foi publicada pelas mulheres paulinas e chamava-se Maturidade Cristã, destinada a estabelecer cursos para os participantes dos sacramentos. O primeiro volume, Pastoral do Batismo, saiu em 1970 e teve sua segunda edição no ano seguinte. O texto era de autoria da Arquidiocese de São Paulo, mas o projeto era coordenado pelo Secretariado Nacional de Liturgia, criado no contexto que se seguiu ao Plano de Emergência de $1962^{207}$. Ao final do livro Pastoral do Batismo, a editora anunciava: "Da mesma coleção:

\footnotetext{
${ }^{205}$ NUNES, Maria José Rosado. "Freiras no Brasil", op. cit.

${ }^{206}$ MONTERO, Paula. "O Papel das Editoras Católicas na Formação Cultural Brasileira”, op. cit., p. 238.

207 AGNELO, Geraldo Majella; KROHLING, Aloísio; PEREIRA, Décio \& SCHIRATO, Sérgio José. Pastoral do Batismo. Subsídio Teológico e Litúrgico. 2. ed. São Paulo, Edições Paulinas, 1971. (Maturidade Cristã, 1).
} 
Pastoral do Matrimônio (subsídio para preparação ao casamento)”. No mesmo espaço, afirmava que "brevemente" seriam lançados outros três volumes da coleção Maturidade Cristã: Pastoral da Crisma, Pastoral da Eucaristia e Pastoral dos Enfermos ${ }^{208}$. A casa aproveitava para divulgar naquela página também outras obras da editora relacionadas à temática do batismo: Por Que Batizar?, de N. Tomasi; O Batismo, Regeneração em Cristo, de Pe. José Etspueler; Do Batismo ao Ato de Fé, de Jean Mouroux; e Alicerce para um Mundo Novo, de Pe. Zezinho ${ }^{209}$.

O período de maior colaboração entre os bispos e a editora se iniciaria em 1973. Naquele ano, Ivo Lorscheiter, então secretário-geral da CNBB e bispo-auxiliar de Porto Alegre, assinava em nome da Conferência um contrato com as Edições Paulinas. Representada por Tarcilla Tommasi, irmã paulina, a editora se comprometia a editar duas coleções: Documentos da CNBB e Estudos da $\mathrm{CNBB}^{210}$. O contrato não especificava, mas a primeira coleção seria publicada pela seção feminina da empresa e a segunda pela masculina.

Era grande o anseio da CNBB de divulgar seus pronunciamentos e diretrizes, assim como suas percepções e avaliações da conjuntura eclesial e social. Para isso, a Conferência dispensa o recebimento de direitos autorais pelas obras. Em troca, receberia cinquenta exemplares de cada título e, caso desejasse obter mais cópias, teria 30\% de desconto "sobre os livros de sua autoria que adquirir na sede da Editora" "211. A editora assumiria "os compromissos financeiros" da "impressão e divulgação dos Documentos e Estudos da CNBB”, e a seu cargo também ficaria o estabelecimento da tiragem de cada

\footnotetext{
${ }^{208}$ Idem, p. 156.

${ }^{209}$ Idem, pp. 157-158.

${ }^{210}$ Contrato de edição entre CNBB e Edições Paulinas, assinado por Ir. Tarcilla Tommasi em São Paulo, 1412-1973 e Dom José Ivo Lorscheiter no Rio de Janeiro, 18.12.1973. Arquivo do Departamento de Direitos Autorais da Editora Paulus.

${ }^{211}$ Idem.
} 
publicação, "de acordo com o mercado" "212. Para um outro elemento editorial, seria necessário o aval dos bispos: o contrato determina que "a editora submeterá à aprovação da CNBB os títulos das coleções e layout das capas" "213. Os títulos já estavam designados. Já as capas de todos os volumes de ambas as séries foram padronizadas, trazendo apenas título da obra, número do volume, nome da coleção e o logo da CNBB. A diferença entre as coleções estava apenas na disposição do texto e na cor das capas, o que levaria os Documentos da CNBB a serem reconhecidos como "série azul" e os Estudos como "série verde”. Até a separação da empresa em Paulinas e Paulus, em 1994, foram publicados 51 volumes da coleção Documentos e 68 da sstudos $^{214}$. A marca Edições Paulinas aparecia apenas na quarta capa, o que conferia um aspecto ainda mais institucional aos livros, que imprimiam apenas o logotipo da Conferência na primeira capa.

Os documentos e estudos da CNBB publicados nessas coleções não se restringiam a orientações eclesiásticas e teológicas. $\mathrm{Na}$ prática, eram também suportes para o posicionamento público dos bispos, como "porta-vozes", e teriam grande repercussão além dos muros da Igreja. Tal foi o caso, por exemplo, do documento $\mathrm{n}^{\mathrm{o}}$ 10: Exigências Cristãs de uma Ordem Política. Publicado em 1977, foi fruto da XV Assembleia Geral da CNBB, que marcaria um momento de efetiva oposição dos bispos, como instituição, à ditadura militar. Àquela altura, diversos membros da Igreja, entre leigos e religiosos, haviam sido detidos, sequestrados, torturados, assassinados. As denúncias eclesiásticas às violações de direitos humanos não se restringiam à sua comunidade - por exemplo, houve uma grande mobilização da Arquidiocese de São Paulo em reação à morte de Vladimir Herzog, que não era católico, em 1975. Mas, houve casos que atingiram

\footnotetext{
212 Idem.

${ }^{213}$ Idem.

214 Após a criação da editora oficial da Conferência, Edições CNBB, em 2005, a Paulinas continuaria imprimindo a coleção Documentos. Já a Paulus logo depois encerraria a coleção Estudos, que passaria a ser de exclusividade da nova editora episcopal.
} 
diretamente a Igreja, como o do assassinato de Padre Henrique, auxiliar de d. Hélder Câmara em Recife, em 1969, casos que marcariam profundamente a postura da Igreja em relação aos militares ${ }^{215}$.

Em uma linguagem bastante direta, as críticas do Exigências Cristãs eram dirigidas sobretudo à violência praticada pelo regime em nome da Doutrina de Segurança Nacional, que se traduzia em insegurança:

A segurança, como bem de uma Nação, é incompatível com uma permanente insegurança do povo. Esta se configura em medidas arbitrárias de repressão, sem possibilidades de defesa, em internamentos compulsórios, em desaparecimentos inexplicáveis, em processos e inquéritos aviltantes, em atos de violência praticados pela valentia fácil do terrorismo clandestino e numa impunidade frequente $\mathrm{e}$ quase total ${ }^{216}$.

O documento condenava, ainda, o que chamava de marginalização, fosse por receber um "salário injusto" e "ser privado da terra por estruturas agrárias inadequadas e injustas" ou mesmo por "não dispor de representatividade eficaz, para fazer chegar aos centros decisórios as próprias necessidades e aspirações"217. Uma condenação, portanto, do próprio autoritarismo, exercido em diversas esferas.

Paulo César Gomes, em sua pesquisa sobre a espionagem dos bispos realizada pela ditadura, encontrou um documento do Cisa - Centro de Informações de Segurança da Aeronáutica - intitulado “Atividades da 'Esquerda Clerical' no Primeiro Semestre de 1977’. Ali, os agentes afirmavam que, a partir da XV Assembleia da CNBB e da publicação do Exigências Cristãs, "verificou-se, no corrente ano, em comparação com os anos

\footnotetext{
${ }^{215}$ Esses casos foram listados pela Comissão Nacional da Verdade em "Violações de Direitos Humanos nas Igrejas Cristãs". In: Relatório da Comissão Nacional da Verdade, vol. 2, 2014.

${ }^{216}$ CNBB. Exigências Cristãs de uma Ordem Política. São Paulo, Edições Paulinas, 1977. (Documentos da CNBB, 10), XI, 37. Ainda que o termo "terrorismo" fosse utilizado pela repressão para se referir às ações da esquerda, os bispos o consideram "impune" - portanto, parecem se referir aos grupos clandestinos de tortura e extermínio ligados ao próprio Estado.

${ }^{217}$ Idem, IX, 23.
} 
anteriores, um incremento na atuação ostensiva e subterrânea da 'ESQUERDA CLERICAL', ao divulgar publicações religiosas de contestação ao Governo" ${ }^{218}$. A comunicação da Igreja preocupa tanto os militares quanto a atuação de padres e bispos nos movimentos pela terra, por exemplo. Em outro trecho, o documento alega que há uma "Exploração, pela CNBB, do tema IGREJA X GOVERNO, procurando apresentar à opinião pública, nacional e mundial, uma imagem distorcida da atual conjuntura do BRASIL"219. Mais uma vez, a opinião pública. No trecho nota-se também outro elemento importante: pela própria natureza transnacional da Igreja Católica, os bispos se fazem ouvir para além de seu território nacional ${ }^{220}$.

O relatório, que, é claro, servia aos objetivos da repressão, fazia leituras muito particulares da Igreja. Além de identificar a CNBB à "esquerda", o que não correspondia à realidade, afirma que após a publicação do Exigências Cristãs ocorrera "uma verdadeira cisão" na Igreja ${ }^{221}$. Pelo contrário. Scott Mainwaring ressalta que Exigências Cristãs de uma Ordem Política foi unânime entre os bispos: o documento fora aprovado em assembleia, com uma votação de 210 a $3^{222}$. Não se tratava, portanto, da atuação de alguns bispos "de esquerda", mas de como o regime tornava-se insustentável para a Igreja como corpo coletivo.

Mais do que isso, para Mainwaring, as críticas episcopais contundentes à marginalização, que reproduzimos acima, superavam a "estreita visão jurídica” das liberdades civis e direitos humanos e defendiam uma participação popular concreta nos

\footnotetext{
${ }^{218}$ Informação 739-Cisa, 16.8.1977 apud GOMES, Paulo César. Os Bispos Católicos e a Ditadura Militar Brasileira. A Visão da Espionagem. Rio de Janeiro, Record, 2014, Caderno de Imagens, p. 14. Destaques do original.

${ }^{219}$ Idem, Caderno de Imagens, p. 15.

${ }^{220}$ Paulo César Gomes lembra que, na década de 1970, o então arcebispo de Olinda e Recife, Hélder Câmara, figurava de forma recorrente em periódicos internacionais, como o francês Le Monde e a americana Time. O próprio jornal do Vaticano chegou a publicar denúncias de religiosos brasileiros sobre a tortura praticada pelo regime (idem, especialmente pp. 121-123).

${ }^{221}$ Idem, Caderno de Imagens, p. 15.

${ }^{222}$ MAINWARING, Scott. A Igreja Católica e a Política no Brasil (1916-1985), op. cit., p. 175.
} 
processos decisórios, contra os "modelos de desenvolvimento elitistas, não participativos, desiguais, mesmo quando legitimados por processos eleitorais [como o que ocorrera em 1974], e respeitam formalmente as liberdades civis convencionais"223.

A própria publicação representa a ideia de que a participação política dos católicos não deveria se restringir a assembleias episcopais fechadas ou a reuniões entre bispos e generais, como foi o caso da Comissão Bipartite, entre 1970 e $1974^{224}$. As desavenças já não eram apenas assuntos de bastidores. A utilização da estrutura nacional de impressão, distribuição e vendas das Edições Paulinas tornava as questões não mais restritas às cúpulas e permitiam que amplos setores da sociedade tivessem acesso ao debate. Nesse sentido, as publicações da CNBB se inserem em um processo de articulação de diversos movimentos católicos que se fortaleciam no período. Considerando que, desde 1973, documentos como esse eram publicados e distribuídos pelas Edições Paulinas, percebese que os bispos não se dirigiam apenas às autoridades, mas a toda a Igreja, entre religiosos e leigos, e, até certo ponto, a toda a sociedade.

Àquela altura, as comunidades eclesiais de base já estavam presentes por todo o país e haviam, inclusive, realizado um primeiro encontro nacional (chamado “intereclesial”) em 1975. Além da importância, para a hierarquia, de manter a vinculação das comunidades à Igreja $\mathrm{a}^{225}$, era impossível negar que, ademais de todos os outros benefícios que traziam à instituição, as CEBs também estancavam as taxas de evasão católica em direção a outra ou mesmo a nenhuma religião. Mais do que isso, estancavam a evasão em direção a outros movimentos sociais, não católicos. Legitimando-as e

${ }^{223}$ Idem, pp. 176-177.

${ }^{224}$ A Comissão Bipartite se reuniu 24 vezes entre novembro de 1970 e agosto de 1974 (durante o governo Médici e primeiros meses de Geisel) e foi destrinchada em SERBIN, Kenneth P. Diálogos na Sombra: Bispos e Militares, Tortura e Justiça Social na Ditadura. São Paulo, Companhia das Letras, 2001. Para uma cronologia das reuniões, ver especialmente pp. 214-216.

${ }^{225}$ Nas palavras de Thomas Skidmore, a atenção dos bispos às comunidades eclesiais de base - benéficas por prescindirem de sacerdotes adicionais - evitava também que elas formassem uma espécie de "igreja paralela" (SKIDMORE, Thomas. "Vozes da Sociedade Civil". Brasil: De Castelo a Tancredo. Rio de Janeiro, Paz e Terra, 1988). 
ressaltando sua importância, os bispos não apenas incentivavam seu desenvolvimento como não escapavam aos objetivos almejados desde os anos 1960, de fortalecimento perante a "opinião pública". E, se os movimentos de base se multiplicavam, o "público" era cada vez mais formado também por eles. Conforme afirmou Alvaro Senra, "a sociedade civil passava por uma diversificação e a CNBB se transformava em sujeito a mais no jogo político" e, com documentos como o Exigências Cristãs, "mobilizava a sua área de influência social”226. Mobilização em muito favorecida, reitera-se, pela edição e distribuição do documento em forma de livro.

Não se trata de considerar apenas a influência sobre a opinião pública como motivação desse conjunto de publicações episcopais. Como vimos, os efeitos do autoritarismo também incidiram diretamente sobre a Igreja, fosse sobre os sacerdotes, fosse sobre os membros de suas paróquias. Embora a questão da influência seja fundamental, ela não é a única, e não pode ser tida como um fim para o qual o posicionamento político e a mobilização social são apenas meios ${ }^{227}$. Porém, como vimos, havia uma movimentação de setores eclesiásticos desde o período conciliar no sentido de se inserir nos meios de comunicação. Observando sua atuação a partir de meados da década de 1970, percebe-se que, sem essa estrutura de "influência" - como a editorial, no caso, das Edições Paulinas -, a própria oposição política católica teria se dado de forma mais limitada.

A outra coleção da Conferência publicada pelas Edições Paulinas, Estudos da CNBB, editada pelos paulinos, divulgava pesquisas de ciências humanas e sociais e

\footnotetext{
${ }^{226}$ SENRA, Alvaro de Oliveira. “CNBB, Democracia e Participação Popular (1977-1989)”. Anos 90, Porto Alegre, vol. 24, n. 46, dez. 2017, p. 106.

227 Tal foi a crítica dirigida por muitos autores à perspectiva institucionalista de BRUNEAU, Thomas. Catolicismo Brasileiro em Época de Transição. São Paulo, Loyola, 1974. Ver, especialmente, o Capítulo VI, "Em Busca de uma Nova Abordagem da Influência: Promoção da Mudança Social”, pp. 139-193. No entanto, nos últimos capítulos do livro, quando observa na Igreja o florescimento de uma oposição importante à ditadura militar, Bruneau não se limita à questão da influência e chega a sugerir, inclusive, o caráter potencialmente revolucionário da Igreja no período.
} 
avaliações teológicas a respeito das comunidades eclesiais de base, da conjuntura política e social e das diversas áreas pastorais (da saúde, carcerária, da terra, do dízimo...). Para a produção dos estudos, havia colaboração de cientistas sociais e outros pesquisadores, o que representava uma aproximação maior entre a Igreja e os intelectuais leigos. A importância dessas equipes de especialistas - como a do Ceris - que desenvolviam trabalhos junto aos bispos foi observada por Michael Löwy. Segundo o autor, esses intelectuais trouxeram à instituição católica formas de compreender a sociedade que vinham sendo desenvolvidas nas universidades latino-americanas, sobretudo a partir do marxismo e da teoria da dependência ${ }^{228}$.

O contrato com a CNBB gerou também consequências na própria prática editorial. Até então, todos os livros da editora traziam as autorizações eclesiásticas determinadas pelo Código de Direito Canônico. O Nihil obstat e o Imprimatur incluíam data, local e nome das autoridades que os concederam. Alguns, inclusive, eram acompanhados por um pequeno texto dessa autoridade, explicando os motivos pelos quais a obra deveria ser publicada, sobretudo quando ela suscitava interesse especial.

No entanto, a partir da década de 1970, as folhas de créditos dos volumes das Edições Paulinas estampam apenas o aviso "Com autorização eclesiástica". Após a aproximação com a CNBB, teria existido uma espécie de acordo tácito entre a editora e os altos quadros da Igreja brasileira que dispensaria a solicitação de autorização para cada obra publicada. Paulinas e paulinos concordam entre si ao afirmar que a "confiança" depositada na editora pelos bispos teria dispensado a partir de então a autorização prévia $^{229}$. Apenas a Bíblia continuava exigindo as formalidades do Nihil obstat e do Imprimatur.

\footnotetext{
${ }^{228}$ LÖWY, Michael. The War of Gods. Religion and Politics in Latin America, op. cit., p. 42.

${ }^{229}$ Cf. depoimentos da irmã paulina Vera Ivanise Bombonatto, 12.4.2019 e do padre paulino Luiz Miguel Duarte, 4.4.2019.
} 
Portanto, assim como a CNBB possuía agora uma forma de edição, distribuição e divulgação de suas obras, a editora também se beneficiava do acordo. Além dos ganhos financeiros pelas vendas, as Edições Paulinas selavam sua proximidade com a cúpula católica brasileira, tornando-se cada vez menos uma iniciativa pontual, pessoal e local, e cada vez mais uma instituição que, se não era oficial, usufruía das vantagens advindas da proximidade com a oficialidade católica. Mas a produção da editora não se limitava às obras da CNBB, tampouco suas relações religiosas e profissionais. Tendo em vista todo o desenvolvimento da editora e da estrutura de comunicação da Igreja apresentados até aqui, no próximo capítulo nos ocuparemos mais detidamente da produção editorial das Edições Paulinas e do espaço que ela passa a ocupar em um campo editorial católico mais amplo. 
Tabela 1. Coleção Documentos da CNBB

\begin{tabular}{|c|c|c|}
\hline Volume & Ano & Título \\
\hline 1 & 1973 & Testemunhar a Fé Viva em Pureza e Unidade \\
\hline 2 & 1974 & Pastoral da Eucaristia: Subsídios \\
\hline $2 \mathrm{a}$ & 1974 & Pastoral dos Sacramentos da Iniciação Cristã \\
\hline 3 & 1975 & Em Favor da Família \\
\hline 4 & 1975 & $\begin{array}{c}\text { Diretrizes Gerais da Ação Pastoral da Igreja no Brasil - 1975- } \\
1978\end{array}$ \\
\hline 5 & 1975 & $3^{\circ}$ Plano Bienal dos Organismos Nacionais - 1975-1976 \\
\hline 6 & 1976 & Pastoral da Penitência \\
\hline 7 & 1976 & Pastoral da Música Litúrgica no Brasil \\
\hline 8 & 1977 & Comunicação Pastoral ao Povo de Deus \\
\hline 9 & 1977 & $4^{\circ}$ Plano Bienal dos Organismos Nacionais - 1977-1978 \\
\hline 10 & 1977 & Exigências Cristãs de uma Ordem Política \\
\hline 11 & 1977 & Diretório para Missas com Grupos Populares \\
\hline 12 & 1978 & Orientações Pastorais sobre o Matrimônio \\
\hline 13 & 1978 & Subsídios para Puebla \\
\hline 14 & 1979 & Pastoral da Unção dos Enfermos \\
\hline 15 & 1979 & Diretrizes Gerais da Ação Pastoral da Igreja no Brasil \\
\hline 16 & 1979 & $5^{\circ}$ Plano Bienal dos Organismos Nacionais - 1979-1980 \\
\hline 17 & 1980 & Igreja e Problemas da Terra \\
\hline 18 & 1980 & Valores Básicos da Vida e da Família \\
\hline 19 & 1980 & Batismo de Crianças \\
\hline 20 & 1981 & Vida e Ministério do Presbítero: Pastoral Vocacional \\
\hline 21 & 1981 & $6^{\circ}$ Plano Bienal dos Organismos Nacionais - 1981-1982 \\
\hline 22 & 1981 & Reflexão Cristã sobre a Conjuntura Política \\
\hline 23 & 1982 & Solo Urbano e Ação Pastoral \\
\hline 24 & 1982 & Pronunciamentos da CNBB-1981-1982 (Coletânea) \\
\hline 25 & 1982 & Comunidades Eclesiais de Base na Igreja do Brasil \\
\hline 26 & 1983 & Catequese Renovada \\
\hline 27 & 1983 & Pronunciamentos da CNBB - 1982-1983 (Coletânea) \\
\hline
\end{tabular}




\begin{tabular}{|c|c|c|}
\hline 28 & 1983 & $\begin{array}{c}\text { Diretrizes Gerais da Ação Pastoral da Igreja no Brasil - 1983- } \\
1984\end{array}$ \\
\hline 29 & 1983 & $7^{\circ}$ Plano Bienal dos Organismos Nacionais - 1983-1984 \\
\hline 30 & 1984 & Formação dos Presbíteros na Igreja do Brasil: Diretrizes Básicas \\
\hline 31 & 1984 & Nordeste: Desafio à Missão da Igreja no Brasil \\
\hline 32 & 1984 & Pronunciamentos da CNBB-1983-1984 (Coletânea) \\
\hline 33 & 1985 & Carta aos Agentes de Pastoral e às Comunidades \\
\hline 34 & 1985 & $8^{\circ}$ Plano Bienal dos Organismos Nacionais - 1985-1986 \\
\hline 35 & 1986 & Pronunciamentos da CNBB-1984-1985 (Coletânea) \\
\hline 36 & 1986 & Por uma Nova Ordem Constitucional: Declaração Pastoral \\
\hline 37 & 1987 & Pronunciamentos da CNBB-1985-1986(Coletânea) \\
\hline 38 & 1987 & $\begin{array}{c}\text { Diretrizes Gerais da Ação Pastoral da Igreja no Brasil - 1987- } \\
1990\end{array}$ \\
\hline 39 & 1987 & $9^{\circ}$ Plano Bienal dos Organismos Nacionais - 1987-1988 \\
\hline 40 & 1988 & $\begin{array}{l}\text { Igreja: Comunhão e Missão na Evangelização dos Povos no } \\
\text { Mundo do Trabalho, da Política e da Cultura }\end{array}$ \\
\hline 41 & 1989 & $10^{\circ}$ Plano Bienal dos Organismos Nacionais - 1989-1990 \\
\hline 42 & 1989 & Exigências Éticas da Ordem Democrática \\
\hline 43 & 1989 & Animação da Vida Litúrgica no Brasil \\
\hline 44 & 1989 & Pronunciamentos da CNBB-1986-1988(Coletânea) \\
\hline 45 & 1991 & $\begin{array}{c}\text { Diretrizes Gerais da Ação Pastoral da Igreja no Brasil - 1991- } \\
1994\end{array}$ \\
\hline 46 & 1991 & $11^{\circ}$ Plano Bienal dos Organismos Nacionais - 1991-1992 \\
\hline 47 & 1992 & Educação, Igreja e Sociedade \\
\hline 48 & 1992 & Das Diretrizes a Santo Domingo \\
\hline 49 & 1993 & $12^{\circ}$ Plano de Pastoral dos Organismos Nacionais - 1993-1994 \\
\hline 50 & 1993 & Ética: Pessoa e Sociedade \\
\hline 51 & 1993 & Pronunciamentos da CNBB-1988-1992 (Coletânea) \\
\hline 52 & 1994 & Orientações para a Celebração da Palavra de Deus \\
\hline 52 & 1994 & Orientações Pastorais sobre a Renovação Carismática Católica \\
\hline
\end{tabular}


Tabela 2. Coleção Estudos da CNBB

\begin{tabular}{|c|c|c|}
\hline Volume & Ano & Título \\
\hline 1 & 1974 & Espiritualidade Presbiteral Hoje \\
\hline 2 & 1974 & Igreja e Política: Subsídios Teológicos \\
\hline 3 & 1974 & Comunidades: Igreja na Base \\
\hline 4 & 1974 & Pastoral Carcerária \\
\hline 5 & 1974 & A Pastoral Vocacional: Realidade, Reflexões e Pistas \\
\hline 6 & 1974 & Igreja e Educação: Perspectivas Pastorais \\
\hline 7 & 1977 & A Família: Mudança e Caminhos \\
\hline 8 & 1975 & Pastoral do Dízimo \\
\hline 9 & 1975 & Pastoral da Saúde \\
\hline 10 & 1976 & Pastoral Social \\
\hline 11 & 1976 & Pastoral da Terra I \\
\hline 12 & 1976 & Estudo sobre os Cantos da Missa \\
\hline 13 & 1976 & Pastoral da Terra II: Posse e Conflitos \\
\hline 14 & 1976 & Educação Religiosa nas Escolas \\
\hline 15 & 1976 & Prostituição: Desafio à Sociedade e à Igreja \\
\hline 16 & 1977 & Conselhos Presbiterais Diocesanos \\
\hline 17 & 1979 & $\begin{array}{c}\text { Com Deus me Deito, com Deus me Levanto: Orações da } \\
\text { Religiosidade Popular Católica }\end{array}$ \\
\hline 18 & 1978 & Manual Simplificado do Trabalhador Rural \\
\hline 19 & 1978 & Por uma Sociedade Superando as Dominações: Primeira Etapa \\
\hline 20 & 1979 & Pastoral da Família \\
\hline 21 & 1979 & Guia Ecumênico \\
\hline 22 & 1979 & Pistas para uma Pastoral Urbana \\
\hline 23 & 1979 & $\begin{array}{c}\text { Comunidades Eclesiais de Base no Brasil: Experiências e } \\
\text { Perspectivas }\end{array}$ \\
\hline 24 & 1979 & Subsídios para uma Política Social \\
\hline 25 & 1980 & O Papa Vem ao Brasil \\
\hline 26 & 1981 & Sofrer em Cristo Jesus: Espiritualidade do Enfermo \\
\hline 27 & 1981 & Bibliografia sobre a Religiosidade Popular \\
\hline
\end{tabular}

${ }^{230}$ Autoria de Francisco van der Poel. 


\begin{tabular}{|c|c|c|}
\hline 28 & 1981 & Pela Unidade dos Cristãos: Guia Ecumênico Popular \\
\hline 29 & 1981 & Situação do Clero no Brasil \\
\hline 30 & 1981 & Propriedade e Uso do Solo Urbano \\
\hline 31 & 1981 & $\begin{array}{c}\text { Cáritas Hoje: Atuação e Opção de Cáritas Brasileira no } 25^{\circ} \\
\text { Aniversário, 1956-1981 }\end{array}$ \\
\hline 32 & 1981 & A Família e a Promoção da Vida \\
\hline 33 & 1982 & $\begin{array}{l}\text { Liturgia de Rádio e Televisão: Conclusões de Quatro Encontros } \\
\text { Nacionais }\end{array}$ \\
\hline 34 & 1983 & Obras Sociais da Igreja no Brasil \\
\hline 35 & 1983 & Campanha da Fraternidade: Vinte Anos de Serviço à Missão da Igreja \\
\hline 36 & 1983 & Guia Pedagógico da Pastoral Vocacional \\
\hline 37 & 1983 & A Pastoral das Migrações \\
\hline 38 & 1983 & Comissão Justiça e Paz: Documentos Normativos ${ }^{232}$ \\
\hline 39 & 1983 & Colaboração Intereclesial no Brasil \\
\hline 40 & 1984 & Situação e Vida dos Seminaristas Maiores no Brasil \\
\hline 41 & 1986 & Para uma Pastoral da Educação \\
\hline 42 & 1986 & Liturgia: 20 Anos de Caminhada Pós-Conciliar \\
\hline 43 & 1986 & Os Povos Indígenas e a Nova República ${ }^{233}$ \\
\hline 44 & 1986 & Pastoral da Juventude no Brasil \\
\hline 45 & 1986 & $\begin{array}{c}\text { Leigos e Participação na Igreja: Reflexão sobre a Caminhada da } \\
\text { Igreja no Brasil }\end{array}$ \\
\hline 46 & 1986 & Guia para o Diálogo Católico-Judaico no Brasil \\
\hline 47 & 1987 & Os Leigos na Igreja e no Mundo: Vinte Anos depois do Vaticano II \\
\hline 48 & 1987 & Assembleia Eletrônica Litúrgica \\
\hline 49 & 1987 & $\begin{array}{c}\text { O Ensino Religioso: Nas Constituições do Brasil, nas Legislações } \\
\text { de Ensino, nas Orientações da Igreja }\end{array}$ \\
\hline 50 & 1987 & A Pastoral Vocacional no Brasil: História e Perspectivas \\
\hline 51 & 1987 & Orientações para os Estudos Filosóficos e Teológicos \\
\hline 52 & 1987 & Guia para o Diálogo Inter-Religioso \\
\hline 53 & 1989 & Textos e Manuais de Catequese: Elaboração, Análise, Avaliação \\
\hline
\end{tabular}

${ }^{231}$ Autoria de Cáritas Brasileira.

${ }^{232}$ Autoria de Comissão Brasileira Justiça e Paz.

${ }^{233}$ Autoria de Conselho Indigenista Missionário da CNBB. 


\begin{tabular}{|c|c|c|}
\hline 54 & 1987 & Migrações no Brasil: Um Desafio à Pastoral \\
\hline 55 & 1987 & Primeira Semana Brasileira de Catequese \\
\hline 56 & 1988 & Evangelização e Pastoral da Universidade \\
\hline 57 & 1988 & Diaconato no Brasil \\
\hline 58 & 1990 & Para Onde Vai a Cultura Brasileira? Desafios Pastorais \\
\hline 59 & 1990 & Formação de Catequistas: Critérios Pastorais \\
\hline 60 & 1990 & $\begin{array}{c}\text { Participação Popular e Cidadania: A Igreja no Processo } \\
\text { Constituinte }\end{array}$ \\
\hline 61 & 1991 & Orientações para a Catequese da Crisma \\
\hline 62 & 1991 & A Igreja Católica diante do Pluralismo Religioso no Brasil I \\
\hline 63 & 1992 & Educação: Exigências Cristãs \\
\hline 64 & 1992 & Diretrizes: 1991-1994: Caminhadas, Desafios, Propostas \\
\hline 65 & 1993 & Pastoral Familiar no Brasil: Objetivos, Organização, Agentes \\
\hline 66 & 1993 & Maçonaria e Igreja: Conciliáveis ou Inconciliáveis? ${ }^{234}$ \\
\hline 67 & 1993 & Santo Domingo: Prioridades e Compromissos Pastorais \\
\hline 68 & 1993 & A Igreja e os Novos Grupos Religiosos \\
\hline 69 & 1993 & A Igreja Católica diante do Pluralismo Religioso no Brasil II \\
\hline $70^{235}$ & 1994 & Missa de Televisão \\
\hline 71 & 1994 & A Igreja Católica diante do Pluralismo Religioso no Brasil III \\
\hline
\end{tabular}

${ }^{234}$ Autoria de Jesús Hortal.

235 O volume 70, Missa de Televisão, é lançado em 1994 já com o selo Paulus, o que leva a crer que o volume 71, com a marca Edições Paulinas, saiu antes. A partir do volume 72, todos são publicados pela Paulus. 


\title{
Capítulo 3
}

\section{As Edições Paulinas no Mercado Editorial Brasileiro}

\author{
Na sala, uma estante, trinta e poucos livros, \\ José Mauro de Vasconcelos e Jorge Amado, \\ Harold Robbins e Sidney Sheldon, J.G. de \\ Araújo Jorge e Lobsang Rampa, Carlos \\ Drummond de Andrade e Graciliano Ramos, \\ Neimar de Barros e Padre Zezinho.
}

Luiz Ruffato, Inferno Provisório 236

\subsection{Um Campo Editorial Católico?}

Na concepção de Pierre Bourdieu, o campo editorial se constitui como autônomo em relação aos outros campos de produção e difusão de bens simbólicos. Em todos estes, uma progressiva profissionalização de seus "produtores e empresários" faz com que passem a obedecer determinadas normas internas ${ }^{237}$ e a disputar, entre si, monopólios sobre tipos determinados de bens e de capital ${ }^{238}$, o que implica, nos termos de Bourdieu, uma disputa de posições dentro de cada campo.

No caso do campo editorial, os editores exercem a função de tornar pública a existência de um texto e/ou de um autor, por meio de uma "transferência de capital simbólico" acumulado pela editora ${ }^{239}$. Entretanto, a acumulação do capital simbólico (isto é, do prestígio) no caso das editoras está atrelada também à de outros tipos de capital,

\footnotetext{
${ }^{236}$ RUFFATO, Luiz. Inferno Provisório. São Paulo, Companhia das Letras, 2016.

${ }^{237}$ BOURDIEU, Pierre. "O Mercado de Bens Simbólicos". A Economia das Trocas Simbólicas, op. cit., p. 100.

${ }^{238}$ BOURDIEU, Pierre. "Séminaires sur le Concept de Champ, 1972-1975", op. cit., p. 21.

${ }^{239}$ BOURDIEU, Pierre. "Uma Revolução Conservadora na Edição". Política \& Sociedade, vol. 17, n. 19, 2018, p. 199.
} 
entre eles, como proposto por John B. Thompson, o econômico, o humano (o pessoal da editora, com suas técnicas e saberes), o social (as redes de contatos e relações) e o intelectual (a propriedade, por exemplo, de direitos autorais) ${ }^{240}$. Mas, estruturalmente, a posição da editora no campo depende sobretudo dos capitais econômico e simbólico ${ }^{241}$.

O conceito de campo editorial despertou e tem despertado o interesse de diversos estudiosos no sentido de compreender as relações estabelecidas entre escritores e editores, tanto do ponto de vista das relações pessoais quanto institucionais, mas, também, da complexa cadeia produtiva que permite situar a produção cultural de um ponto de vista simbólico e mercadológico.

Thompson vai além na compreensão do conceito, afirmando que, dentro do campo editorial, verificam-se vários campos específicos em que os atores se relacionam entre si (por exemplo, campo editorial científico, literário etc.) e, também, com o campo editorial mais amplo ${ }^{242}$. Por isso, tendo em vista a complexidade e o alcance das editoras católicas no Brasil, na segunda metade do século XX, é possível considerar que, ao mesmo tempo em que elas disputam posições no campo editorial, também competem entre si segundo lógicas próprias, formando um campo editorial religioso e, de modo mais específico, um campo editorial católico ${ }^{243}$.

Essa perspectiva lança luz sobre o papel das Edições Paulinas no campo editorial brasileiro e, em particular, no que podemos conceber como o campo editorial católico, no período em tela, a saber, entre 1962 e 1994. Nosso ponto de partida guarda uma relação estreita com fatores externos da organização da Igreja, na medida em que o Concílio

\footnotetext{
${ }^{240}$ THOMPSON, John B. Mercadores de Cultura: O Mercado Editorial no Século XXI. São Paulo, Unesp, 2013, pp. 11-12.

241 Idem, p. 15.

${ }^{242}$ Idem, p. 10.

${ }^{243}$ Como foi sugerido por Agueda Bittencourt em seu artigo sobre as editoras católicas atualmente em atividade (BITTENCOURT, Agueda Bernardete. "O Livro e o Selo: Editoras Católicas no Brasil". ProPosições, vol. 25, n. 1 (73), jan.-abr. 2014, pp. 117-137).
} 
Vaticano II demandou novas respostas das editoras religiosas diante dos problemas sociais e políticos que se colocavam no início da década de 1960, particularmente aqueles relacionados ao debate sobre as condições de vida no Terceiro Mundo (cf. Capítulo 1). Porém, não podemos desprezar, tratando-se do caso brasileiro, o impacto que os programas em prol do desenvolvimento nacional tiveram sobre a indústria gráfica, em consonância com o próprio aumento das comunidades de leitores, nos anos 1950. A análise se estende até 1994, quando as Edições Paulinas sofrem uma reestruturação, o que, certamente, como pretendemos demonstrar, altera a lógica de decisões dos editores envolvidos com a construção do seu catálogo, logo, as estratégias e as práticas editoriais estabelecidas.

A análise bourdieusiana ecoa de forma muito nítida em nossa pesquisa. Afinal, como aponta o autor em outro estudo modelar sobre o campo editorial francês,

Cada editora ocupa, em um dado momento, uma posição no campo editorial, que depende de sua posição na distribuição dos recursos raros (econômicos, simbólicos, técnicos etc.) e dos poderes por eles conferidos; é essa posição estrutural que orienta as tomadas de posição de seus "dirigentes", suas estratégias para publicação de obras francesas ou estrangeiras, definindo o sistema de coerções e de finalidades que se impõe, assim como as "margens de manobra", muitas vezes bem estreitas, que se delimitam nos confrontos e nas lutas entre os protagonistas do jogo editorial. A mudança mais significativa que se observa na política de diferentes editoras tem a ver com mudanças na posição que ocupam no campo $[\ldots]^{244}$.

Mas, como podemos igualmente observar nessa passagem, não basta adotar o conceito do autor, seria necessário, antes, esquadrinhar todo o campo editorial brasileiro no período em estudo e, em seguida, partir para uma imersão naquilo que supomos se tratar de um campo editorial católico, para, enfim, compreendermos o lugar de nossa editora no campo editorial brasileiro e católico, os limites de sua autonomia nas tomadas

\footnotetext{
${ }^{244}$ BOURDIEU, Pierre. "Uma Revolução Conservadora na Edição”, op. cit., p. 200.
} 
de decisão para a publicação (ou não) de um título, o grau de capilaridade de seus livros, a partir de dados de difícil acesso como as tiragens e os canais de distribuição, além de tantos outros dados que nos faltam para completar esse quadro ${ }^{245}$. Apesar das lacunas apontadas, parece evidente que as editoras católicas se organizavam internamente frente a um campo mais amplo que se desenvolvia em uma conjuntura bastante favorável, tanto em termos intelectuais quanto materiais.

Notemos que entre 1950 e 1960, a indústria gráfica cresce 143,3\%, principalmente com os incentivos do governo Juscelino Kubitschek (1956-1961) à importação de maquinário $^{246}$. É justamente nesse momento, em 1957, que as Edições Paulinas montam um parque gráfico em São Paulo, em prédios separados para as mulheres e homens. No final da década de 1950 a nova gráfica já possuía três máquinas Intertype. Alguns trabalhos realizados em São Paulo, no entanto, eram enviados para a impressão em Caxias do Sul, primeira cidade em que os paulinos adquiriram impressoras Offset $^{247}$, ou mesmo impressos em outras gráficas de São Paulo ${ }^{248}$.

\footnotetext{
${ }^{245}$ Por conta da ausência de outras fontes que fornecessem uma visão de conjunto do catálogo da editora estudada, realizamos um levantamento de seus livros presentes no acervo da Biblioteca Nacional, isto é, a partir do depósito legal. Foram identificadas cerca de três mil edições entre 1978 (os anos anteriores contavam com um número muito pequeno de registros) e 1994. O número, entretanto, não representa o total de publicações, o que foi percebido por duas razões principais. Primeiro, porque grande parte das coleções não estava disponível integralmente, o que demonstra a ausência de muitos títulos no acervo; segundo, porque muitas reedições não estavam registradas (por exemplo, há títulos que têm apenas a $3^{\mathrm{a}} \mathrm{e}$ a $6^{\mathrm{a}}$ edições disponíveis). Além disso, muitas vezes uma reedição é registrada com o ano da primeira edição. Portanto, todas as informações que fornecemos neste trabalho a respeito das datas precisaram ser conferidas nos próprios livros. A incompletude impossibilita análises estatísticas precisas; no entanto, o levantamento foi fundamental para compreender qualitativamente diversos aspectos do catálogo da editora. A partir dele, conseguimos buscar nas fontes principais (isto é, nos livros) mais informações, por exemplo, sobre os volumes pertencentes às coleções. Nesse sentido, esse levantamento foi uma primeira aproximação com o objeto de estudo, mas, para fornecer dados a respeito do "campo", ele ainda é insuficiente, pois carece de totalidade.

${ }^{246}$ HALLEWELL, Laurence. O Livro no Brasil: Sua História. São Paulo, Edusp, 2012, p. 585.

${ }^{247}$ Depoimento de Luiz Miguel Duarte, 4.4.2019.

${ }^{248}$ Foi o caso, por exemplo, do documento da Conferência de Puebla, do Celam, de 1979, impresso na gráfica das Escolas Profissionais Salesianas, na Mooca, em São Paulo. Essa gráfica produzia altas tiragens para muitas editoras do período, principalmente didáticas (CONSELHO ESPISCOPAL LATINOAMERICANO. Evangelização no Presente e no Futuro da América Latina. Conclusões da Conferência de Puebla. Texto Oficial. São Paulo, Edições Paulinas, 1979).
} 
Já no início da década de 1960, essa indústria sofre um abalo econômico; ainda assim, o período é intelectual, política e editorialmente rico. $\mathrm{O}$ fator político, então, tornase predominante nas mudanças que se operam no mercado, em termos dos agentes inscritos na cadeia produtiva (particularmente autores e editores). Exemplo significativo é o da editora Civilização Brasileira, de Ênio Silveira. Em 1962, ele lança seu projeto mais popular, os Cadernos do Povo Brasileiro, em uma conjuntura de crise econômica, logo, de alta dos custos de produção, o que não impede o êxito do projeto e as altas tiragens $^{249}$. Após o Golpe de 1964 e, especialmente, após a decretação do AI-5 no final de 1968, os projetos editoriais de esquerda, como os de Ênio, sofrem com a repressão e se arrefecem. Novos projetos editoriais de oposição ganhariam força a partir do governo Geisel, em 1974, mas, sobretudo, com o novo fôlego dos movimentos sociais nos anos finais da década ${ }^{250}$.

A partir de fins da década de 1970, inicia-se também uma onda de recuperação material da indústria do livro. De um lado, novas facilitações governamentais à importação de maquinário e à fabricação de papel $^{251}$. De outro, sistematização da distribuição de livros didáticos, o que, além de beneficiar empresas já existentes, como Melhoramentos e FTD, esta mantida pela congregação católica dos irmãos maristas, fomentou o surgimento de novos fenômenos editoriais, em especial a Editora Ática ${ }^{252}$.

Notemos que o crescimento do setor educacional não se restringiu aos didáticos para o ensino básico. A expansão universitária criou uma grande demanda por mais títulos, edições, tiragens e, inclusive, traduções de obras que antes circulavam, em volume reduzido, apenas em idiomas estrangeiros. Entre 1967 e 1980, as matrículas no ensino

\footnotetext{
249 Ver, entre outros, LOVATTO, Angélica. "Ênio Silveira e os Cadernos do Povo Brasileiro". Lutas Sociais, São Paulo, n. 23, pp. 93-103, 2009.

${ }^{250}$ Cf. MAUÉS, Flamarion. Livros Contra a Ditadura: Editoras de Oposição no Brasil, 1974-1984, op. cit., pp. 10-11.

${ }^{251}$ HALLEWELL, Laurence. O Livro no Brasil: Sua História, op. cit., pp. 609-610.

${ }^{252}$ Idem, pp. 612-618.
} 
superior público cresceram $453 \%$ e, no privado, $523 \%{ }^{253}$. Inclusive algumas editoras religiosas se adaptaram à nova demanda, como a Vozes, que nesse período expandiu seu catálogo para livros de ciências humanas ${ }^{254}$, o que contribuiu para o crescimento da empresa ao longo da década de 1970. Em 1979, a Vozes foi a casa que mais publicou no Brasil $^{255}$.

De 1975 a 1985 a produção de livros de literatura infantil, não didáticos, também cresceu acentuadamente. Hallewell o atribui não apenas à obrigatoriedade, instituída em 1972, da leitura de uma obra de literatura brasileira por semestre nos primeiros e segundos graus, como, de forma geral, ao aumento da escolarização ${ }^{256}$. Nesse setor, as publicadoras católicas teriam um papel importante. A Salesiana Dom Bosco, por exemplo, cresce nesse período graças aos livros infantis. Nas Edições Paulinas, o gênero começa a ser editado em 1980 e, a partir de 1982, começa a ocupar cada vez mais espaço no catálogo, o que coincide, conforme veremos, com seu período de maior expressão no mercado editorial brasileiro.

O período de alta industrialização também se traduz na popularização dos impressos, que não se restringe ao público infantil, mas atinge setores cada vez mais amplos das massas urbanas. Por exemplo, o lançamento da coleção Primeiros Passos pela Brasiliense no final da década de 1970; o crescimento acelerado da Record no mesmo período; e a imensa quantidade de livros vendidos em circuitos alternativos, como bancas de jornal ou clubes do livro, representados principalmente pela Abril e pelo Círculo do $\operatorname{Livro}^{257}$.

\footnotetext{
${ }^{253}$ MARTINS, Carlos Benedito. “A Reforma Universitária de 1968 e a Abertura para o Ensino Superior Privado no Brasil". Educação \& Sociedade, vol. 30, n. 106, jan.-abr. 2009.

${ }^{254}$ MONTERO, Paula. "Letras Católicas na Sociedade de Massas", op. cit., p. 171.

${ }^{255}$ Pelo número de edições. Cf. HALLEWELL, Laurence. O Livro no Brasil: Sua História, op. cit., p. 914.

${ }^{256}$ Idem, p. 768.

257 cf. idem.
} 
Se, como vimos, há uma mudança qualitativa do mercado nessa nova conjuntura da economia do livro, que se coloca desde 1964 e se estende até a época da abertura política, é preciso observar em que medida essas mudanças se relacionam com a sociedade e, de modo especial, com o público almejado.

O próprio projeto moralmente conservador da ditadura militar também beneficiou, indiretamente, as editoras religiosas. A censura prévia sobre os livros, estabelecida em fevereiro de 1970, recaía apenas sobre os que versassem a respeito de "sexo, moralidade pública e bons costumes" ${ }^{258}$, o que, por razões óbvias, poupava os livros católicos. Mais do que isso, fomentava a venda de livros sobre comportamento - que tinham ampla popularidade $^{259}$ - em uma chave conservadora.

Ao mesmo tempo, a guinada de setores da alta hierarquia da Igreja à oposição ${ }^{260}$ ao regime também favoreceria a circulação das publicações de algumas das editoras católicas $^{261}$, como apontamos no caso da CNBB, no capítulo 2. Mais do que isso, a Igreja e seus espaços de reunião passam a ser vistos como instâncias potenciais de mobilização e transformação social. Nas palavras de Thomas Skidmore, a partir de meados da década de 1970, por conta da repressão a outros canais de associação, a Igreja "tornou-se um ponto de reunião para católicos e não católicos brasileiros que em tempos normais talvez

\footnotetext{
${ }^{258}$ REIMÃO, Sandra. “'Proíbo a Publicação e Circulação...' - Censura a Livros na Ditadura Militar”. Estudos Avançados, vol. 28, n. 80, jan.-abr. 2014.

${ }^{259}$ Ecléa Bosi, no início da década de 1970, realizou pesquisa em uma fábrica de Osasco, na Grande São Paulo, a respeito dos livros que circulavam entre as operárias. Eram dominantes os livros a respeito da sexualidade, sobre a qual especialmente as mulheres careciam de informações (cf. BOSI, Ecléa. Cultura de Massa e Cultura Popular: Leituras de Operárias. Petrópolis, Vozes, 1972).

${ }^{260} \mathrm{Se}$ a oposição institucional se deu principalmente em relação à defesa dos direitos humanos, com a expansão das comunidades eclesiais de base e sua aproximação com outros movimentos sociais - alguns dos quais nasceram dentro das CEBs, como o Movimento Custo de Vida -, inclusive com o novo sindicalismo, os setores católicos influenciados pela teologia da libertação participaram da articulação de uma nova esquerda, privilegiando cada vez mais a crítica econômica e social.

${ }^{261}$ Dizemos algumas pois havia, também, editoras que mantiveram uma linha católica mais tradicionalista, como Ave Maria (Claretianos, São Paulo), Santuário (Redentoristas, Aparecida) e Salesiana (Salesianos, São Paulo) (cf. BITTENCOURT, Agueda Bernardete. "O Livro e o Selo: Editoras Católicas no Brasil", op. cit., p. 121).
} 
não lhe dessem muita atenção" ${ }^{262}$. De modo geral, o interesse das esquerdas e dos intelectuais pela Igreja aumenta e permanece alto até a redemocratização ${ }^{263}$.

Nem sempre as questões políticas que se colocam vão de par com a conjuntura econômica do período. Se o processo de abertura política demanda novas publicações, portanto, respostas a questões lançadas sobre os novos tempos, a crise econômica se apresenta como um entrave importante para o desenvolvimento pleno de novas e antigas editoras. Os primeiros anos da década de 1980 são de crise em todas as frentes: além do aumento generalizado dos custos de produção e altíssima inflação, a indústria do livro se depara com problemas como escassez de papel $^{264}$. Os efeitos da crise se estenderam pelos anos seguintes e atingiram principalmente os trabalhadores de renda mais baixa. Os livros mais baratos e populares, como os vendidos a prestação ou em bancas de jornal, têm suas vendas reduzidas drasticamente ${ }^{265}$.

Durante e após a crise, as casas religiosas despontam entre as maiores editoras do país; incluindo as católicas Loyola (jesuíta) e Santuário (redentoristas) e a Sinodal (luterana), até então pouco representativas no cenário editorial ${ }^{266}$. Além de questões específicas como escolhas de catálogo, por suas próprias especificidades, incluindo subsídios da Igreja e associação com outras instituições religiosas para financiamento de edições, as editoras religiosas resistiram melhor às flutuações econômicas do período. E,

\footnotetext{
${ }^{262}$ SKIDMORE, Thomas. "A Igreja: Uma Força de Oposição". Brasil: De Castelo a Tancredo, op. cit.

${ }^{263}$ Em levantamento realizado por Flamarion Maués, entre os sete títulos de oposição publicados pela Civilização Brasileira presentes nas listas de mais vendidos entre 1978 e 1984, três eram escritos por religiosos católicos (muito conhecidos pelo engajamento político): Creio na Justiça e na Esperança, de D. Pedro Casaldáliga (1978); Mil Razões para Viver, de D. Hélder Câmara (1979) e Batismo de Sangue: Os Dominicanos e a Morte de Carlos Marighella, de Frei Betto (1982) (MAUÉS, Flamarion. Livros Contra a Ditadura: Editoras de Oposição no Brasil, 1974-1984, op. cit., p. 49). Há de se acrescentar, também, que Ênio Silveira participara da fundação da editora Paz e Terra em 1968, que buscava uma aproximação dos intelectuais de esquerda com setores religiosos progressistas. Da mesma forma a Brasiliense: muitos dos volumes mais vendidos da coleção Primeiros Passos tratavam sobre a Igreja contemporânea (cf. REIMÃO, Sandra \& CRENI, Gisela (org.). Caio Graco Prado e a Editora Brasiliense. São Paulo, Biblioteca Brasiliana Guita e José Mindlin, 2020, pp. 101-103).

${ }^{264}$ HALLEWELL, Laurence. O Livro no Brasil: Sua História, op. cit., p. 809.

${ }^{265}$ Idem, pp. 811-812.

${ }^{266}$ Idem, pp. 914, 934.
} 
entre essas, as católicas exerciam predominância, já que contavam com: 1. uma instituição religiosa transnacional, de forte poder econômico, religioso e político, além de uma rede bastante capilarizada pelo país, que não inclui apenas paróquias, mas também seminários, conventos, universidades etc.; 2. uma estrutura editorial que vinha se consolidando há décadas, por meio da acumulação dos diferentes tipos de capital, como os referidos por John B. Thompson, citado acima; 3. uma comunidade de fiéis muito mais ampla que a de outras religiões, o que implica um público leitor maior e inclui aqueles a quem a venda de determinados impressos é dada como garantida, tais como livros de missa para sacerdotes; 4. um grande número de produtores, isto é, leigos ou religiosos autores de livros católicos.

É justamente nessa conjuntura de crise que as Edições Paulinas vivem não somente seu período mais produtivo, como o mais relevante no cenário editorial do país. No início da década de 1980, o número de publicações aumentou muito rapidamente. Em 1980, as Edições Paulinas estavam em $16^{\circ}$ entre as editoras brasileiras, por número de títulos publicados $(72)^{267}$. Conforme tabela abaixo, em 1984, a editora chegou a ser a quarta maior do Brasil por número de títulos publicados, o que a situava após Vozes, Brasiliense e Record. Comparada a essas, possuía a maior tiragem média por título (7.029), menor, no entanto, do que o desempenho da Ática (9.424), José Olympio (7.716) e Salesiana $(7.190)^{268}$; e menor do que o das editoras cuja distribuição se fazia por assinatura ou por bancas de jornal, isto é, Abril (16.739), que apresentou a maior tiragem média do ano, e Círculo do Livro $(9.963)^{269}$.

\footnotetext{
${ }^{267}$ Leia Livros, n. 33, março/abril de 1981.

${ }^{268}$ Os exemplares de livros didáticos não estão inclusos.

${ }^{269}$ Leia Livros, n. 80, junho de 1985.
} 


\section{Tabela 3. Maiores Editoras em 1984}

Ordem de classificação por número de títulos.

\begin{tabular}{|c|c|c|c|c|c|}
\hline & Editora & Títulos & Exemplares & $\begin{array}{c}\text { Tiragem média } \\
\text { por título }\end{array}$ & $\begin{array}{l}\% 1^{\text {as }} \text { edições/ } \\
\text { total de títulos }\end{array}$ \\
\hline 1 & Record & 565 & 3.765 .556 & 6.664 & $37 \%$ \\
\hline 2 & Brasiliense & 415 & 1.994 .000 & 4.684 & $41 \%$ \\
\hline 3 & Vozes & 356 & 2.056 .766 & 5.793 & $36 \%$ \\
\hline 4 & Edições Paulinas & 349 & 2.453 .766 & 7.029 & $47 \%$ \\
\hline 5 & Círculo do Livro & 309 & 3.078 .687 & 9.963 & - \\
\hline 6 & Nova Fronteira & 249 & 1.446 .000 & 5.807 & $51 \%$ \\
\hline 7 & Abril & 184 & 1.446 .000 & 16.739 & $49 \%$ \\
\hline 8 & Forense & 173 & 442.950 & 2560 & $31 \%$ \\
\hline 9 & Melhoramentos & 146 & - & - & $34 \%$ \\
\hline 10 & Ática & 132 & 1.244 .000 & 9.424 & $44 \%$ \\
\hline 11 & Nobel & 128 & - & - & $23 \%$ \\
\hline 11 & Saraiva & 128 & - & - & $46 \%$ \\
\hline 12 & Atlas & 125 & - & - & $18 \%$ \\
\hline 13 & Pensamento & 122 & - & - & $39 \%$ \\
\hline 14 & Loyola & 114 & 387.500 & 3.399 & $65 \%$ \\
\hline 15 & Revista dos Tribunais & 105 & - & - & $72 \%$ \\
\hline 16 & Global & 96 & 357.000 & 3.718 & $59 \%$ \\
\hline 17 & Salesiana & 94 & 675.920 & 7.190 & $68 \%$ \\
\hline 18 & Globo (RJ) & 77 & 341.000 & 4.429 & $18 \%$ \\
\hline 19 & José Olympio & 74 & 571.000 & 7.716 & $30 \%$ \\
\hline 19 & Nacional & 74 & 462.707 & 6,252 & $3 \%$ \\
\hline
\end{tabular}

Fonte: Leia Livros, $n$. 80, junho de 1985. 
Em 1985, as Edições Paulinas se manteriam em quarto lugar pelo número de títulos $(419)^{270}$ e, em 1987, se alçariam à segunda posição, com 512, atrás apenas da Record, com $820^{271}$. A fonte para esses dados, o jornal Leia Livros, foi publicado entre 1980 e 1988, o que impossibilita uma comparação com os anos posteriores. Porém, de acordo com Hallewell, no início da década seguinte esses números diminuiriam drasticamente para todo o mercado editorial, tendo a Brasiliense, por exemplo, publicado apenas 88 títulos em $1990^{272}$. Embora o levantamento dos títulos publicados pela Edições Paulinas, realizado a partir do depósito legal na Biblioteca Nacional, não nos permita análises quantitativas precisas, por não cobrir toda a produção da editora, os dados possibilitam, ao menos observar que no início dos anos 1990 a editora seguiu publicando uma mesma quantidade de títulos em relação aos anos anteriores. Ou seja, não houve um encolhimento visível, o que reforça a ideia de que a casa conseguia manter uma estabilidade maior quando comparada com outras empresas.

Em relação à questão econômica, essa estabilidade pode ser explicada por alguns fatores. Primeiro, contavam com receitas relativamente garantidas - não somente pelas assinaturas de grande escala, de revistas e de folhetos litúrgicos, mas também por livros cuja venda já possuía um público cativo, tais como os livros de missa e os documentos institucionais, da CNBB ou do Papa ${ }^{273}$; livros que, mais do que isso, contribuíam para propiciar uma legitimidade católica à editora: ainda que não fosse oficial, estava respaldada pela oficialidade, o que, nos termos de Bourdieu, lhe garantia uma posição privilegiada no que seria o campo editorial católico. Além disso, grande parte dos livros

\footnotetext{
${ }^{270}$ Leia Livros, n. 92, junho de 1986.

${ }^{271}$ HALLEWELL, Laurence. O Livro no Brasil: Sua História. São Paulo, Edusp, 2012, p. 934.

${ }^{272}$ Idem, p. 935.

${ }^{273}$ Logo após o Concílio, em 1965, as Edições Paulinas criam a coleção A Voz do Papa, formada por decretos, encíclicas e outros documentos. Além do público religioso, a coleção visava também popularizar as decisões e a própria figura papal. O próprio título indicava abertura e familiaridade, ainda mais se a compararmos à coleção semelhante que já era publicada pela Vozes, mas se chamava Documentos Pontifícios.
} 
publicados eram realizados em parceria com outras instituições, em sua maioria, mas não todas, religiosas, cuja participação se dava, muitas vezes, por meio da compra de uma parcela significativa dos exemplares tirados. Finalmente, o fato da editora ser parte de uma estrutura maior de comunicação, compreendendo livrarias próprias, periódicos, uma gravadora de discos (desde 1964) e uma estação de rádio (desde 1977) - isso tudo além de irmãs paulinas dirigirem o setor de comunicação da CNBB a partir de 1979 -, favorecia também os livros, já que os títulos e autores contavam com diversos canais de divulgação. Veremos esses dois últimos pontos mais detidamente na próxima seção deste capítulo.

Além desses fatores, nos quais se observa que a questão econômica estava indiscutivelmente atrelada à religiosa, o que proporcionava à editora vantagens que as laicas não possuíam, há também o elemento propriamente religioso. Esse capital simbólico, acumulado ao longo do tempo, lhe confere um status próprio e isso lhe permite, inclusive, diversificar o catálogo, englobando a partir dos últimos anos da década de 1970 livros que mesclam a questão religiosa às questões políticas e sociais, numa chave progressista. Essa diversificação também permite que as Edições Paulinas mantenham sua concorrência (ou “disputem posições”) com a maior católica do país, a Vozes ${ }^{274}$. Ainda é preciso levar em conta que o crescimento das comunidades eclesiais de base e de movimentos nem sempre controlados diretamente pela hierarquia eclesiástica lembremos que mesmo a Ação Católica, organizada mais verticalmente, já fugia ao controle dos bispos na década de 1950 - obriga a Igreja a reforçar seu papel de dar a última palavra sobre as questões da religião, e um dos caminhos encontrados é a produção de publicações. Por outro lado, também, os próprios membros das congregaçõos paulinas passam a se envolver cada vez mais nos projetos da autodenominada "Igreja Popular".

\footnotetext{
${ }^{274}$ Com a qual chegou, também, a publicar algumas edições conjuntas nas décadas de 1980 e 1990, como as diversas versões da Liturgia das Horas/Ofício Divino da CNBB.
} 
Scott Mainwaring propõe uma cronologia das fases em que as diversas alas da Igreja Católica exerceram hegemonia no Brasil em meados do século XX. Divide-os entre tradicionalistas, modernizadores conservadores e reformistas. Dos últimos, sairiam os mais progressistas, próximos à esquerda, que ele chama, adotando o vocabulário católico, de Igreja Popular. Para ele, da criação da CNBB, nos anos 1950, até 1970, essa hegemonia era compartilhada entre os modernizadores conservadores e os reformistas. Já entre 1970 e 1976 ganharam mais espaço os reformistas, os quais, a partir de 1976, dividem a cena com os mais radicais, isto é, os membros da "Igreja Popular". Estes, a seu ver, começariam a perder sua força por volta de 1982, com as pressões do Vaticano, cedendo seu lugar hegemônico aos reformistas mais moderados ${ }^{275}$. O aumento das publicações das Edições Paulinas dirigidas à "Igreja Popular" ocorre justamente nesse momento, no começo da década de 1980 e, nesse sentido, pode ser encarado como uma forma de manter vivos e atuantes esses projetos, também porque os movimentos sociais (e os partidos políticos) começavam a se reorganizar em outros espaços para além da Igreja.

Após a constituinte, as Edições Paulinas abandonam progressivamente a fase de experimentação política - muito, também, pelas pressões de João Paulo II, visando afastar a Igreja da esquerda. A partir de então, seu catálogo se afasta gradualmente dos temas políticos, passando a privilegiar obras mais tradicionais ou de espiritualidade próxima à autoajuda, esta última em crescimento acelerado desde fins da década de 1980. Assim, a publicação pelas Edições Paulinas da Bíblia Pastoral e das coleções a ela relacionadas no início dos anos 1990, como último grande projeto editorial ligado à Teologia da Libertação, marcam o fim de um período da edição católica no Brasil.

\footnotetext{
${ }^{275}$ MAINWARING, Scott. A Igreja Católica e a Política no Brasil (1916-1985), op. cit.
} 


\subsection{Edições Paulinas: Estratégias e Práticas Editoriais}

Desde o início, o objetivo das Edições Paulinas era atingir as grandes massas de leitores, sem se limitar aos livros litúrgicos ou de estudo teológico. A partir da década de 1960, começa a se transformar a concepção que a Igreja Católica possui da sociedade como, também, as expectativas que o público possui em relação a essa instituição. Dessa forma, a mudança nas publicações era uma resposta necessária tanto à conjuntura política e eclesiástica quanto às necessidades comerciais, visando atender às novas demandas dos frequentadores de livrarias e, também, se fortalecer perante a concorrência.

Em 1979, paulinos e paulinas criam, conjuntamente, a Proep - Propaganda e Promoção de Edições Paulinas. No registro de fundação no Diário Oficial do Estado de São Paulo são firmados os seguintes propósitos:

[...] promover todas as edições e produções da Pia Sociedade de São Paulo e da Pia Sociedade Filhas de São Paulo, denominadas Edições Paulinas, através de inserções de publicidade em jornais, revistas e outros meios de comunicação, como imprensa falada, escrita e televisada; mandar confeccionar boletins, folhetos, catálogos, expedindo-os por mala direta para endereços de suas listagens ou adquirida de outros; participar e patrocinar feiras e encontros promocionais do livro em geral, fazer por meios próprios ou contratar terceiros pesquisas de mercado ou de opinião pública; promover, distribuir, dar em consignação: livros, revistas e demais publicações de Edições Paulinas, enfim comercializar de comum acordo com a Pia Sociedade de São Paulo e Pia Sociedade Filhas de São Paulo, todas suas publicações, cuja finalidade primordial é a evangelização através dos meios de comunicação social ${ }^{276}$.

Como viemos demonstrando, as duas congregações editavam, imprimiam e vendiam livros diferentes, de forma separada. Havia, no entanto, certa dependência das livrarias paulinas em relação ao catálogo dos paulinos. Embora a produção das mulheres

\footnotetext{
276 "Proep - Propaganda e Promoção de Edições Paulinas. Extrato para Registro dos Estatutos no Cartório Sizenando Silveira". Diário Oficial do Estado de São Paulo, 12.5.1979, p. 37. A Proep seria dissolvida em 1995 (a informação consta na ficha cadastral da empresa na Junta Comercial do Estado de São Paulo), após a extinção da marca Edições Paulinas.
} 
fosse bastante diversificada e contasse também com periódicos importantes, como a Família Cristã, apenas os paulinos editavam Bíblias, livros litúrgicos e de teologia. Com a criação do Proep, a produção editorial mantém-se apartada, mas a venda e a divulgação passam por uma integração maior, beneficiando ambas as sociedades. A nova empresa tinha em vista, também, coordenar uma maior distribuição para outras livrarias além daquelas da congregação, fortalecendo, assim, sua ascendência sobre o mercado editorial, fosse católico ou não.

As Edições Paulinas, sobretudo após a criação do Proep, que sistematiza o marketing da editora, passam a divulgar sua produção também em mídias de maior circulação, não restritas aos círculos católicos (como ocorria nas décadas iniciais). Por exemplo, uma edição de 1986 do jornal Leia Livros, reproduz uma campanha paga da editora: "Assine a Família Cristã e concorra a um Fusca zerinho, além de outros prêmios" 277 . O texto, em linguagem coloquial, fora da formalidade eclesiástica, era acompanhado pela marca Edições Paulinas (EP) e a ilustração de um Fusca, carro mais vendido da época e maior objeto de grande parte da população ${ }^{278}$.

O anúncio abaixo, publicado na Folha de S. Paulo, em 1985, demonstra como o logo EP era constantemente reproduzido pela empresa. Trata-se de uma propaganda das novas instalações da livraria da Vila Mariana, gerenciada pelas irmãs paulinas, especificidade que, entretanto, não é anunciada - ao contrário das décadas anteriores, em que o trabalho das duas congregações era divulgado de forma totalmente separada, após a criação da Proep há um esforço maior de trabalho conjunto e busca-se valorizar a marca

\footnotetext{
${ }^{277}$ Leia Livros, n. 92, jun. 1986, p. 4.

${ }^{278}$ Embora o Leia Livros fosse laico, nota-se nele (assim como no próprio catálogo da Brasiliense na época, dirigida pelos mesmos editores do jornal) um grande interesse pela Igreja progressista e a Teologia da Libertação. A capa da edição n. 72, de outubro de 1984, reproduz uma foto de Leonardo Boff acompanhada da legenda/título "Boff, o Herege". No periódico, eram recorrentes resenhas e entrevistas sobre o mesmo tema. Em 1980, dois números seguidos dão atenção às mesmas questões: o n. 25 (jun.-jul.) traz uma resenha de A Igreja de Wojtila. Um Santuário da Oposição (org. Rubem César Fernandes, Prefácio de D. Cláudio Hummes [então bispo de Santo André], Brasiliense, 1980); já o n. 26 (jul.-ago.) publica um artigo de Tristão de Athayde (pseudônimo de Alceu Amoroso Lima) intitulado "O Carismático Cardeal Arns".
} 
EP em si, unificada. A divisão entre as seções masculina e feminina restringia-se, assim, aos bastidores da editora. Para o mundo externo, ela era exibida como uma só.

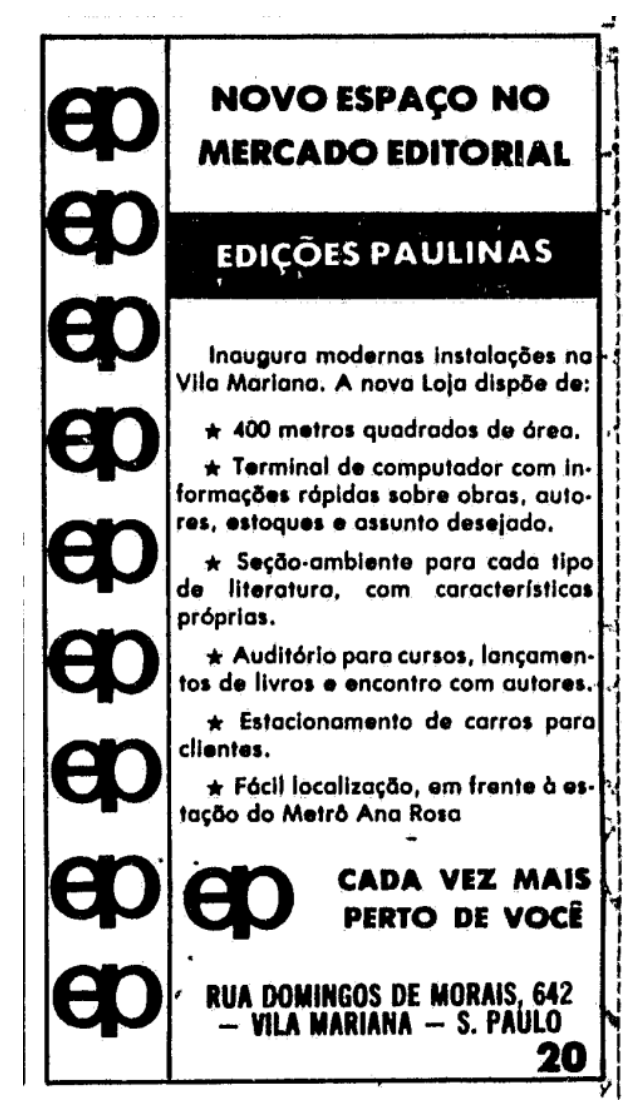

Figura 6: Folha de S. Paulo, 30.6.1985, Caderno Ilustrada, p. 83.

Além da marca, o que chama mais atenção no anúncio acima é o fato de não haver nenhuma menção ao caráter católico, nem mesmo religioso, da livraria ou da editora. Pelo contrário, acentua-se sua diversidade, afirmando que há uma "seção-ambiente para cada tipo de literatura, com características próprias”. Embora a literatura em si, isto é, livros de ficção, já não tivessem espaço no catálogo da editora. As publicações de ficção eram restritas, então, às obras infantis. E a livraria vendia, com poucas exceções, somente livros próprios. Tem-se ainda a ênfase no caráter moderno da livraria, que contava com um terminal de computador já em 1985, o que, por extensão, conferia modernidade à própria marca EP. 
Uma polêmica nos jornais sugere que o EP era, de fato, amplamente associado às Edições Paulinas. Outra empresa, chamada Edições Populares, também adotara o EP como logo na década de 1970. Além de publicarem as obras completas de Che Guevara ${ }^{279}$ e outros livros de esquerda, como Rosa Luxemburgo, as Edições Populares traziam propostas radicais, como o que viria a ser conhecido como literatura marginal. Em 1977, no lançamento de Boca do Lixo, de Hiroito de Moraes Joanides (cuja sinopse fornecida pela editora afirmava: "Depoimento de um ex-bandido, ex-rei da boca do lixo"), a Folha de S. Paulo divulga-o como publicação das Edições Paulinas! ${ }^{280}$ Quase dez anos depois, quando Hiroito volta às manchetes, o jornal reproduz o equívoco ${ }^{281}$, fato que motiva a carta de um leitor:

[...] o que mais choca na notícia é que o livro de sua autoria [...] tenha sido editado pelas Edições Paulinas. Salvo engano, esta editora pertence a uma ordem religiosa ou instituição ligada à Igreja Católica. Será que alguma autoridade eclesiástica também está dedicada a "recuperar" o autor do livro? 282

Mas, como já dito, tratava-se de outra editora, laica e independente ${ }^{283}$. Nota-se, entretanto, a inserção que as Edições Paulinas possuíam não apenas no mercado editorial, como no debate público, podendo ser o EP, nesse período, automaticamente associado a uma editora católica.

\footnotetext{
279 Ainda hoje, muitos volumes dessa coleção constam em sistemas de bibliotecas e livrarias como publicados pelas Edições Paulinas. Esta foi, inclusive, a forma como chegamos à questão.

${ }^{280}$ ANGELO, Assis. "Hiroito: O Diabo Escreveu um Livro". Folha de S. Paulo, 3.9.1977, p. 29.

281 CANDA, Josué. "Ex-'Rei da Boca' Coordena Campanha de Samir Achôa". Folha de S. Paulo, 12.9.1986, p. 9.

${ }^{282}$ SOUZA, Túlio Campelo de. "Rei da Boca”. Folha de S. Paulo, 19.9.1986, Painel do Leitor, p. 3.

283 Ainda que, por certa ironia da história, o fundador e editor responsável das Edições Populares se chamasse Analdino Rodrigues Paulino Neto.
} 


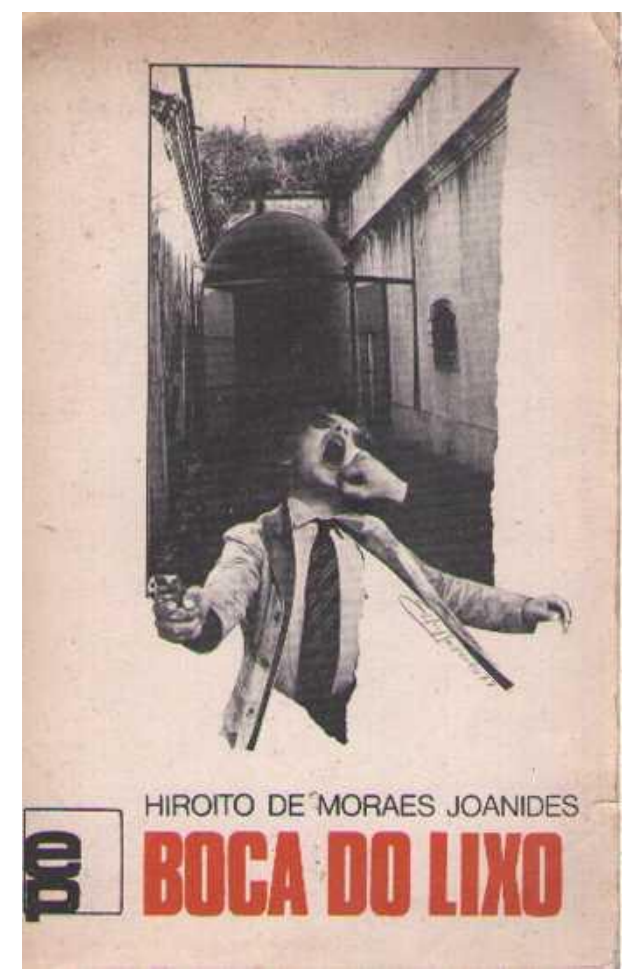

Figura 7: Hiroito de Moraes Joanides. Boca do Lixo. São Paulo, Edições Populares, 1977. À esquerda, o logo EP, referente a Edições Populares.

Os anúncios na Folha de S. Paulo e no jornal Leia Livros, este último voltado para leitores frequentes, fazem parte de um anseio da editora de se inserir no mercado editorial mais amplo, além daquele propriamente católico. Ela mantém seu catálogo estritamente religioso, mas, na grande imprensa, busca também enfatizar seu caráter de editora “comum”. Como comentado, desde fins da década de 1970, com o projeto da Bíblia de Jerusalém, as Edições Paulinas vinham se aproximando dos setores universitários leigos. No caso da seção feminina, essa aproximação ocorria frequentemente pelos departamentos de comunicação. Em 1970, é criada a UCBC - União Cristã Brasileira de Comunicação. Diferentemente da antiga Associação dos Jornalistas Católicos, a UCBC era ecumênica (incluía cristãos protestantes) e progressista. Ismar de Oliveira Soares, na época professor da ECA-USP (Escola de Comunicações e Artes da Universidade de São Paulo), foi um dos presidentes da UCBC, na década de 1980. Embora criada na esteira da 
organização da comunicação eclesiástica pela CNBB, Soares afirma que as posições da União demoraram a ser aceitas pela alta hierarquia. De início, funcionava de forma paralela e independente ao Setor Meios de Comunicação Social (antigo Secretariado Nacional de Opinião Pública) da CNBB:

O inspirador da UCBC, Frei Romeu Dale, sugeriu que a organização se mantivesse fora do comando direto da hierarquia, fato que permitiria aos seus associados fugir ao controle de uma máquina administrativa eclesiástica que, no momento, se mostrava incapaz de aceitar ideias que não fossem geradas dentro de seu contraditório universo de conivência com o situacionismo [...]. O trabalho persistente da UCBC, contudo, com suas reflexões e seus projetos, permeará, através dos anos, a doutrina da Igreja brasileira sobre a Comunicação social, até ser praticamente aceito pelo Setor de Comunicação Social da CNBB no final da década de 1970 e inícios de $1980^{284}$.

Recorde-se que, entre 1979 e 1991, o Setor Meios de Comunicação Social da CNBB

foi dirigido por duas irmãs paulinas. No mesmo período, as atividades e membros da UCBC se multiplicavam. Seus primeiros congressos foram bianuais e, a partir de 1974, passam a ocorrer todos os anos, cada edição em uma cidade do país. Entre 1976 e 1981, a União publica livros pela Loyola; depois de 1982, somente pelas Edições Paulinas. Entre seus membros havia diversos professores da ECA-USP, da PUC-SP, da Unimep (Universidade Metodista de Piracicaba), da UCMG (Universidade Católica de Minas Gerais), do Itesp (Instituto Teológico São Paulo) e de outras instituições, como das Igrejas Luterana e Metodista ${ }^{285}$. Nesse mesmo período, em meados dos anos 1980, passa a exercer papel de destaque na UCBC a irmã paulina Joana Puntel, graduada em jornalismo pela Faculdade Cásper Líbero (1975), mestra em comunicação pela Universidade Metodista de São Paulo (1985) e, depois, doutora em comunicação pela Universidade de

\footnotetext{
${ }^{284}$ SOARES, Ismar de Oliveira. Do Santo Ofício à Libertação: O Discurso e a Prática do Vaticano e da Igreja Católica no Brasil sobre a Comunicação Social, op. cit., pp. 274, 376. Grifo meu. O livro foi publicado pelas mulheres paulinas, assim como, na década de 1980, os da UCBC.

285 SOARES, Ismar de Oliveira \& PUNTEL, Joana (org.). Comunicação, Igreja e Estado na América Latina. XIII Congresso da UCBC. São Paulo, Edições Paulinas/UCBC, 1985, pp. 227-230.
} 
São Paulo (1996). Puntel foi responsável pela revista Família Cristã e sua trajetória acadêmica e profissional representa como a congregação feminina se transformava desde a década de $1970^{286}$.

Em 1982, as irmãs paulinas criam no centro de São Paulo o Sepac, Serviço à Pastoral de Comunicação, também na chave da comunicação "popular" e progressista da Igreja. Nas palavras de Natália Maccari, então diretora da seção feminina das Edições Paulinas, "O Sepac nasceu com dois objetivos específicos: produção de material popular para ser editado e dar cursos de formação na sede e fora da sede: nas paróquias, nas periferias" $^{287}$.

Como discutiremos mais detidamente no capítulo seguinte, havia um esforço da Igreja Católica em formar lideranças, os agentes de pastoral, para atuar principalmente nas comunidades eclesiais de base. No caso do Sepac, tratava-se, de acordo com as paulinas, de formar lideranças não apenas para que atuassem em outros canais de comunicação católico, mas, também, no sentido de uma formação teórica, para refletir a respeito da comunicação contemporânea a partir de uma perspectiva católica progressista. Ivani Pulga, primeira diretora do Sepac, relatou à pesquisadora Helena Corazza: "era época da censura e tínhamos a ideia de que podíamos despertar no povo a consciência crítica mediante a análise do sistema de comunicação" ${ }^{288}$. Além das próprias irmãs paulinas, membros da UCBC, como Ismar de Oliveira Soares, e outros professores universitários ministravam cursos e assessoravam projetos no Sepac.

\footnotetext{
${ }^{286}$ A UCBC manteve-se atuante até 2010, quando foi incorporada à seção brasileira da Signis, associação internacional que busca reunir diversos órgãos de mídia católica (cf. CORAZZA, Helena. Educomunicação: Caminhos e Perspectivas na Formação Pastoral. A Experiência do Serviço à Pastoral de Comunicação (Sepac). Tese de Doutorado em Ciências da Comunicação, Universidade de São Paulo, 2015, p. 68), o que representou, em relação às comunicações, um enfraquecimento do esforço ecumênico. ${ }^{287}$ Natália Maccari apud CORAZZA, Helena. Educomunicação: Caminhos e Perspectivas na Formação Pastoral. A Experiência do Serviço à Pastoral de Comunicação (Sepac), op. cit., p. 94. Helena Corazza, também irmã paulina, trabalhou na UCBC e no Sepac.

${ }^{288}$ Ivani Pulga apud idem, p. 96.
} 
Enquanto isso, os paulinos também estabeleciam relações com o mundo universitário, mas sobretudo pela atuação editorial. Nos anos 1980, publicam em edição conjunta com a Educ, editora da PUC-SP, a Coleção PUC Estudos, mas apenas estudos teológicos ou sobre Igreja Católica, em especial sobre as comunidades eclesiais de base, de autores como D. Pedro Casaldáliga e José J. Queiroz. Ao aumentar sua inserção nos círculos intelectuais e universitários, a editora expande seu catálogo de estudos, mas continua publicando somente aqueles relacionados, de alguma forma, ao catolicismo. A coleção Sociologia e Religião, iniciada em 1984 pelos paulinos, publica Durkheim (As Formas Elementares da Vida Religiosa) e Peter Berger (O Dossel Sagrado). Ainda que não fossem livros católicos, mantinham-se dentro da temática religiosa. Por volta de 1985, os paulinos estreiam também a coleção Amor e Psique, dedicada a estudos de psicologia junguiana, muitos das quais na chave cristã ou, pelo menos, em uma chave mística $^{289}$. A coleção Filosofia, iniciada pelos paulinos em 1980, era quase inteiramente formada por traduções de manuais de filosofia de Battista Mondin, sacerdote católico italiano.

Ainda que aumentassem seus vínculos com outras organizações da sociedade, a maioria das instituições com as quais as Edições Paulinas trabalhariam eram religiosas (cf. Tabela 4). Esses terceiros entravam como autores (como a CNBB), tradutores (como a equipe do CPV - Centro de Pastoral Vergueiro - ou o grupo de tradução São Domingos ${ }^{290}$ ), ou coeditores.

Por exemplo, na década de 1980 cerca de oito títulos foram publicados em “coedição" com o Carmelo Imaculado Coração de Maria e Santa Teresinha de Cotia, São

\footnotetext{
${ }^{289}$ A coleção Amor e Psique foi coordenada por Ivo Storniolo, um dos tradutores da Bíblia Pastoral, como será comentado no Capítulo 4 do presente trabalho.

${ }^{290}$ Surgido em 1982, agregava leigos e religiosos para difusão cultural da teologia da libertação e dos movimentos sociais e ela associados. Mais tarde, expandiu suas atividades, passando a se chamar Grupo Solidário São Domingos, encerrado em 2002. Seu arquivo consta no CEDIC da PUC-SP.
} 
Paulo. A parceria com o convento era recorrente e podia ocorrer pela tradução, revisão, ou mesmo por financiamento de parte da edição, por meio da compra de uma quantidade de exemplares estabelecida em contrato, quando se denominava coedição. O livro Santa Teresa de Jesus, Mestra de Vida Espiritual, tradução do original de Gabriel de Santa Maria Madalena, padre carmelita belga, passou por percalços contratuais e teve sua publicação adiada em três anos. O primeiro contrato, de 1983, foi cancelado um ano depois, após a priora do Carmelo, Maria Aparecida, informar aos paulinos que a compra de 1500 exemplares não poderia ser realizada. Alguns dias depois, o editor paulino Abramo Parmegianni responde à irmã, pedindo que mantivesse o compromisso, e oferece uma redução da obrigação para 750 exemplares, a 50\% do valor de capa. Ele escreve que “tirar simplesmente o livro do mercado, agora que já foi feita a revisão, foi investido para a capa e a preparação na gráfica, seria bem desagradável, tanto mais que o livro já está anunciado". Um novo contrato é assinado em dezembro de 1985 e a primeira edição sai em julho do ano seguinte ${ }^{291}$.

Na Tabela 4 aparecem listadas as instituições que participaram da produção de livros com as Edições Paulinas entre 1978 e 1994 (obtida a partir dos livros a que tivemos acesso, em sua versão física ou registrados em catálogos e acervos). Além das oficiais, como dioceses ou comissões da CNBB, há também grupos que formam parte de uma rede “ecumênica” progressista que vinha se constituindo desde a década de 1960. Ecumênica, e não católica ou simplesmente religiosa, pois muitos grupos contavam também com a presença de protestantes, mas cristãos. Embora, na maioria deles, os católicos exercessem hegemonia - como no caso da Cehila, Comissão de Estudos de História da Igreja na América Latina e no Caribe, por exemplo. Dessa forma, a editora não se limitava ao

\footnotetext{
${ }^{291}$ Contratos e cartas pertencentes ao arquivo do Departamento de Direitos Autorais da editora Paulus.
} 
caráter de "imprensa oficial" da Igreja no Brasil, mas estabelecia vínculos também com outros grupos com os quais possuísse afinidades.

Mesmo no caso das publicações das dioceses e arquidioceses, já na década de 1980 essas publicações não se restringem a conteúdos litúrgicos. Na coleção Cadernos de Base, por exemplo, com livretos por vezes chamados "cartilhas" 292 para uso das comunidades eclesiais de base, havia volumes com temas políticos, alguns dos quais com autoria da Arquidiocese de Vitória ${ }^{293}$ (entre eles o vol. 4, Beabá do Sindicato, 1981, mas também o vol. 3, Encontro com Nossa Senhora, 1981) e da equipe de pastoral da Diocese de Juazeiro ${ }^{294}$ (vol. 17, O Povo Descobre a Sociedade: "Capitalismo X Socialismo”: Subsídio para Reflexões de CEBs, 1984).

\footnotetext{
${ }^{292}$ Muitos autores se referiam a essas publicações como cartilhas, o que reforça seu caráter não apenas pedagógico, mas também normativo (diferente de "caderno", que supõe uma interação mais ativa). Sobre as "cartilhas", ver, por exemplo, KRISCHKE, Paulo \& MAINWARING, Scott (org.). A Igreja Nas Bases Em Tempo de Transição (1974-1985). Porto Alegre, L\&PM, 1986. Por vezes, o uso do termo também era nativo. O volume 7 da coleção Cadernos de Base se chamava justamente Cartilha das Comunidades Eclesiais de Base. De autoria da Região Episcopal de Itapecerica da Serra (SP), foi lançado em 1982.

${ }^{293}$ Seu arcebispo era então João Batista da Mota e Albuquerque, conhecido pelo incentivo aos movimentos leigos como as comunidades eclesiais de base e as juventudes da Ação Católica, organizou, por exemplo, a Pastoral Operária de Vitória.

${ }^{294}$ Então dirigida pelo bispo José Rodrigues de Souza, que atuou na Comissão Pastoral da Terra (CPT) e trabalhou na defesa da população atingida pela construção da Usina Hidrelétrica de Sobradinho. Este movimento, aliado a outros de diversas regiões do país, teve participação da CPT; conjuntamente, culminaram na organização do Movimento dos Atingidos por Barragens (MAB).
} 


\section{Tabela 4. Instituições Parceiras das Edições Paulinas (1978-1994)}

(Inclui instituições que tiveram livros publicados pelas Edições Paulinas, que publicaram em edição conjunta ou que colaboraram na tradução e edição. Não inclui livros traduzidos de instituições estrangeiras sem sede no Brasil, como as do Vaticano.

Os nomes estão reproduzidos como constam nos livros).

\begin{tabular}{|c|c|c|}
\hline Instituição & Denominação & Local \\
\hline Arquidiocese de Campinas & Católica & Campinas, SP \\
\hline Arquidiocese de São Paulo & Católica & São Paulo \\
\hline Arquidiocese de Vitória & Católica & Vitória, ES \\
\hline Cáritas Brasileira & Católica & Brasília \\
\hline $\begin{array}{l}\text { Carmelo do Imaculado Coração de Maria e Santa } \\
\text { Teresinha }\end{array}$ & Católica & Cotia, SP \\
\hline Carmelitas Descalças do Convento de Santa Teresa & Católica & Rio de Janeiro \\
\hline Cear - Centro Ecumênico de Ação e Reflexão & Ecumênica & Diversos \\
\hline Cebi - Centro de Estudos Bíblicos & Ecumênica & $\begin{array}{l}\text { São Leopoldo, } \\
\text { RS }\end{array}$ \\
\hline $\begin{array}{l}\text { Cedhal - Centro de Estudos de Demografia } \\
\text { Histórica da América Latina da USP }\end{array}$ & Laica & São Paulo \\
\hline $\begin{array}{l}\text { Cedi - Centro Ecumênico de Documentação e } \\
\text { Informação }\end{array}$ & Ecumênica & $\begin{array}{l}\text { Rio de Janeiro } \\
\text { e São Paulo }\end{array}$ \\
\hline $\begin{array}{l}\text { Cehila - Comissão de Estudos de História da Igreja } \\
\text { na América Latina e no Caribe }\end{array}$ & Ecumênica & Rio de Janeiro \\
\hline $\begin{array}{l}\text { Celadec - Comissão Evangélica Latino-Americana } \\
\text { de Educação Cristã }\end{array}$ & $\begin{array}{l}\text { Protestante/ } \\
\text { Ecumênica }\end{array}$ & Diversos \\
\hline Celam - Conselho Episcopal Latino-Americano & Católica & Diversos \\
\hline CEM - Centro de Estudos Migratórios & Católica & São Paulo \\
\hline $\begin{array}{l}\text { Cendhec - Centro Dom Helder Câmara de Estudos } \\
\text { e Ação Social }\end{array}$ & Laica & Recife \\
\hline $\begin{array}{l}\text { Centro Bíblico de Belo Horizonte / SAB - Serviço } \\
\text { de Animação Bíblica }\end{array}$ & Católica & Belo Horizonte \\
\hline $\begin{array}{l}\text { Cesep - Centro Ecumênico de Serviços à } \\
\text { Evangelização e Educação Popular }\end{array}$ & Ecumênica & São Paulo \\
\hline Cimi - Conselho Indigenista Missionário & Católica & Brasília \\
\hline
\end{tabular}




\begin{tabular}{|c|c|c|}
\hline $\begin{array}{l}\text { CNBB - Conferência Nacional dos Bispos do } \\
\text { Brasil }\end{array}$ & Católica & Brasília \\
\hline Comissão Brasileira Justiça e Paz & Católica & Brasília \\
\hline $\begin{array}{l}\text { Comissão Nacional de Serviço da Renovação } \\
\text { Carismática Católica }\end{array}$ & Católica & São Paulo \\
\hline Comissão Pastoral da Terra do Rio Grande do Sul & Católica & RS \\
\hline Comissão Pastoral Operária de Curitiba & Católica & Curitiba \\
\hline Comunidade Taizé de Alagoinhas & Ecumênica & Alagoinhas, BA \\
\hline $\begin{array}{l}\text { Conic - Conselho Nacional de Igrejas Cristãs do } \\
\text { Brasil }\end{array}$ & Ecumênica & Brasília \\
\hline CPT - Comissão Pastoral da Terra & Católica & Diversos \\
\hline CPV - Centro de Pastoral Vergueiro & Católica & São Paulo \\
\hline Diocese de Guarulhos & Católica & Guarulhos, SP \\
\hline Diocese de Juazeiro & Católica & Juazeiro, BA \\
\hline Diocese de Lins e Araçatuba & Católica & SP \\
\hline Diocese de Miracema do Norte & Católica & $\begin{array}{ll}\text { Miracema } & \text { do } \\
\text { Norte, } & \text { GO } \\
(\text { atual TO) } & \end{array}$ \\
\hline Diocese de São Mateus - ES & Católica & São Mateus, ES \\
\hline $\begin{array}{l}\text { Dioceses de Caratinga, Teófilo Otoni, Divinópolis } \\
\text { e Araçuaí }\end{array}$ & Católica & MG \\
\hline Educ - Editora da PUC-SP & Católica & São Paulo \\
\hline $\begin{array}{l}\text { Faculdade de Filosofia, Ciências e Letras Santo } \\
\text { Tomás de Aquino }\end{array}$ & Católica & Uberaba, MG \\
\hline Faculdade de Teologia Nossa Senhora de Assunção & Católica & São Paulo \\
\hline $\begin{array}{l}\text { FASE - Federação de Órgãos para Assistência } \\
\text { Social e Educacional }\end{array}$ & Laica & Rio de Janeiro \\
\hline Federação Bíblica Católica & Católica & Diversos \\
\hline Filhos da Caridade & Católica & $\begin{array}{l}\text { Santo André, } \\
\text { SP }\end{array}$ \\
\hline $\begin{array}{l}\text { Grupo de Trabalho Contra a Discriminação Racial } \\
\text { da Universidade de Brasília }\end{array}$ & Laica & Brasília \\
\hline Grupo de Tradução São Domingos & Ecumênica & São Paulo \\
\hline
\end{tabular}




\begin{tabular}{|c|c|c|}
\hline Idac - Instituto de Ação Cultural & Laica & Diversos \\
\hline Instituto Nacional de Pastoral & Católica & Brasília \\
\hline Instituto Sedes Sapientiae & Laica & São Paulo \\
\hline $\begin{array}{l}\text { Intercom - Sociedade Brasileira de Estudos } \\
\text { Interdisciplinares da Comunicação }\end{array}$ & Laica & São Paulo \\
\hline Iter - Instituto de Teologia do Recife & Católica & Recife \\
\hline JOC - Juventude Operária Católica & Católica & Diversos \\
\hline Loyola (Editora) & Católica & São Paulo \\
\hline Missionários do Espírito Santo & Católica & São Paulo \\
\hline Monges Beneditinos de Serra Clara & Católica & $\begin{array}{l}\text { Delfim } \\
\text { Moreira, MG }\end{array}$ \\
\hline Monjas Dominicanas & Católica & São Roque, SP \\
\hline $\begin{array}{l}\text { Movimento de Desarmamento, Justiça e Não } \\
\text { Violência de Vila Califórnia }\end{array}$ & Laica & São Paulo \\
\hline OAF - Organização de Auxílio Fraterno & Católica & São Paulo \\
\hline Pastoral Operária de São Bernardo de Campo & Católica & $\begin{array}{l}\text { São Bernardo } \\
\text { do Campo, SP }\end{array}$ \\
\hline Pastoral Rural da Diocese de Santarém & Católica & Santarém, PA \\
\hline Região Episcopal de Itapecerica da Serra & Católica & $\begin{array}{l}\text { Itapecerica da } \\
\text { Serra, SP }\end{array}$ \\
\hline Regional Nordeste II da CNBB & Católica & $\mathrm{AL}, \mathrm{PE}, \mathrm{PB}$ e RN \\
\hline Regional Norte II da CNBB & Católica & PA e AP \\
\hline $\begin{array}{l}\text { Reindal - Recuperação Integral do Doente } \\
\text { Alcoólico }\end{array}$ & Laica & São Paulo \\
\hline Sinodal (Editora) & $\begin{array}{l}\text { Protestante } \\
\text { (Luterana) }\end{array}$ & $\begin{array}{l}\text { São Leopoldo, } \\
\text { RS }\end{array}$ \\
\hline $\begin{array}{l}\text { Taps - Associação Brasileira de Tecnologia } \\
\text { Alternativa na Promoção da Saúde }\end{array}$ & Laica & São Paulo \\
\hline $\begin{array}{l}\text { UCBC - União Cristã Brasileira de Comunicação } \\
\text { Social }\end{array}$ & Ecumênica & São Paulo \\
\hline Unimep - Universidade Metodista de Piracicaba & Protestante & Piracicaba, SP \\
\hline Vozes (Editora) & Católica & Petrópolis, RJ \\
\hline
\end{tabular}


No levantamento realizado a partir do acervo da Biblioteca Nacional, entre os livros das Edições Paulinas do período 1978-1994, os nacionais superam as traduções, totalizando $57 \%$ das edições. Entre os traduzidos, a maior parte é do inglês (13\%), seguido pelo francês $(11 \%)$ e espanhol (8\%). Os livros de origem italiana, dominantes na editora nas primeiras décadas, se reduzem a 7\%. Há, também, algumas edições traduzidas do alemão (3\%), sobretudo de teologia. Além de uma porcentagem pouco expressiva (1\%) de traduções a partir de outros idiomas (como latim e holandês).

A grande quantidade de edições originalmente em português está relacionada, também, aos livros de maior sucesso do catálogo, que tiveram um número alto de reedições. A partir da década de 1970, José Fernandes de Oliveira, o Padre Zezinho, torna-se o autor mais importante das Edições Paulinas, tanto da seção masculina quanto da feminina. Para compreender seu sucesso editorial, é preciso lembrar de sua carreira musical. Desde 1969, Zezinho compunha e interpretava canções católicas populares, muitas ao estilo da Jovem Guarda, em álbuns gravados pelo setor fonográfico das Edições Paulinas. As irmãs paulinas residentes em Curitiba já produziam discos há alguns anos e, em 1964, um estúdio maior, nomeado EPD - Edições Paulinas Discos - é montado em São Paulo $^{295}$, cidade que aos poucos centralizaria as atividades do grupo. Se os primeiros LPS eram voltados para uso nas catequeses e missas, com Padre Zezinho busca-se atingir um público maior.

Em 1971, o primeiro livro de Padre Zezinho é lançado pelas irmãs paulinas. Alicerce Para um Mundo Novo: A Fé Explicadas aos Jovens. Neste, assim como nos subsequentes, o autor pretende se aproximar do público jovem, utilizando uma linguagem mais informal e próxima - por exemplo, dirige-se diretamente ao leitor, utilizando "você”. Da parte das editoras, a contribuição a esse objetivo está sobretudo nas fotografias, que,

295 NOGUEIRA, Maria. “O Apostolado do Som”. In: IRMÃs Paulinas. 1931-1981. 50 Anos a Serviço do Evangelho, op. cit., pp. 141-142. 
nas capas e no miolo, representam jovens contemporâneos, vestidos à moda da época (cf. figura abaixo). A primeira parte do livro é uma espécie de catecismo, trata dos dogmas e da liturgia de forma simplificada. Já na segunda, que seria a maior característica de Zezinho, são tratados temas da vida cotidiana, como a relação com a cultura secular e, especialmente, com a sexualidade. Quanto à primeira, há um capítulo a respeito dos meios de comunicação, no qual, mesmo que em tom menos prescritivo, como orientava o Concílio Vaticano II, observa-se uma continuidade do dualismo entre a boa e a má imprensa, cuja distinção cabia ao leitor:

[...] se você possui suficiente critério cristão, você saberá fazer uso dos meios de comunicação sem ser usado por eles. [...] Volte-se para a boa imprensa. Aceite os homens e mulheres que comunicam com seriedade e bons propósitos, mesmo que não ofereçam uma visão totalmente cristã da vida, você encontrará ótimos filmes, ótimas mensagens na televisão, no rádio e na imprensa. Separe o joio do trigo. [...] Há um esforço positivo de autoridades e homens sérios: junte-se a eles. Não espere por uma proibição da Igreja. Em nome do bom senso, [...] saiba ignorar o que não é honesto ${ }^{296}$.

Nas páginas anteriores, havia, inclusive, menção às Edições Paulinas e a outras católicas, Vozes e Duas Cidades, cujos endereços eram fornecidos para que o leitor entrasse em contato e pedisse "o catálogo dos livros e discos colocados a serviço dos jovens" ${ }^{297}$. O interessante é que, diferente do usual - em páginas adicionais ao fim do livro ou mesmo na quarta capa -, a divulgação das editoras se fazia no próprio corpo do texto, o que explicita a intervenção editorial ${ }^{298}$.

\footnotetext{
${ }^{296}$ PE. ZEZINHO, scj. Alicerce Para um Mundo Novo: A Fé Explicadas aos Jovens. São Paulo, Edições Paulinas, 1971, pp. 362-363.

${ }^{297}$ Idem, pp. 359-360.

${ }^{298} \mathrm{O}$ caso faz pensar no circuito das comunicações elaborado por Robert Darnton, no qual o movimento não ocorre apenas no sentido autor $\rightarrow$ editor (por exemplo, quando o autor entrega um original), mas em uma via de mão dupla, pois ao mesmo tempo há o caminho inverso autor $\leftarrow$ editor. Por isso, ele propõe uma simultaneidade autor $\leftrightarrow$ editor, movimentos não necessariamente desmembráveis. Cf. DARNTON, Robert. "O Que É a História dos Livros?". O Beijo de Lamourette. Mídia, Cultura e Revolução. São Paulo, Companhia das Letras, 1990.
} 
Padre Zezinho seria a grande aposta da empresa naquela década. Em 1974, ele é capa da revista Família Cristã, sob a manchete: “Quem é Pe. Zezinho scj ${ }^{299}$ ?" (cf. figura abaixo). O tratamento dado a esse autor específico difere muito dos outros da editora. Nesse sentido, foi se constituindo como primeiro padre "celebridade" do Brasil, já antes da Renovação Carismática. O esforço coletivo das seções feminina e masculina ao redor de sua figura demonstra como as diversas mídias produzidas pelas Edições Paulinas trabalhavam sistematicamente. Publicavam seus livros, gravavam seus discos e promoviam sua imagem e seu nome nos periódicos.

Ao mesmo tempo, sua fama beneficia outras produções da editora e é beneficiada por elas. Em um livro de 1977, publicado pelas mulheres da congregação e de autoria de outro padre, Hilário Cristofolini, há um pequeno texto assinado por "Pe. Zezinho, scj” na quarta capa, apresentando a obra ${ }^{300}$. Ao final da quarta edição desse livro intitulado Deus Mora na Contramão, as editoras acrescentam impressões que teriam sido recebidas dos leitores, sob o título "Os que leram Deus Mora na Contramão escrevem". Uma das “cartas”, que se endereça ao autor do livro, menciona: “[...] O Pe. Zezinho é bárbaro, e falou a verdade quando fez o comentário de seu livro" ${ }^{301}$. Dessa forma, inclusive em outros títulos e coleções, os editores davam espaço e visibilidade a Zezinho. Se paratextos como prefácios, orelhas e quartas capas são escritos por pessoas que detêm certo reconhecimento ou autoridade para o público da obra em questão, o inverso também ocorre. Isto é, a própria concessão desses espaços ao nome "Pe. Zezinho, scj” faz parte de um projeto midiático - livros, discos, revistas - de construção de sua figura, pois lhe confere um status especial.

\footnotetext{
299 “scj” refere-se à Congregação dos Sacerdotes do Sagrado Coração de Jesus.

${ }^{300}$ CRISTOFOLINI imc, Pe. Hilário. Deus Mora na Contramão, op. cit.

301 Idem, p. 129.
} 
Depois de seu primeiro livro publicado, Alicerce Para um Mundo Novo, o autor ganharia coleções só para si. Além da Alicerce (paulinas), a coleção Compromisso ${ }^{302}$ (paulinos) seria a mais conhecida. Também voltada à juventude, tratava sobretudo de questões de relacionamento e sexualidade. Seu principal título, Esta Juventude Magnífica e Seus Namoros Nem Sempre Maravilhosos..., lançado pela primeira vez em 1976, teria 22 edições até 1993, e continuaria a ser editado posteriormente sob a marca Paulus. Na década de 1980, as coleções Jovens Adultos e Sentir com os Jovens, dos paulinos, também seria exclusiva de Padre Zezinho.

${ }^{302}$ Esta contou também com um título de Carlos Afonso Schmitt, Quem Ama se Compromete: Para os que Não Têm Medo da Verdade. São Paulo, Edições Paulinas, 1975. (Compromisso). 

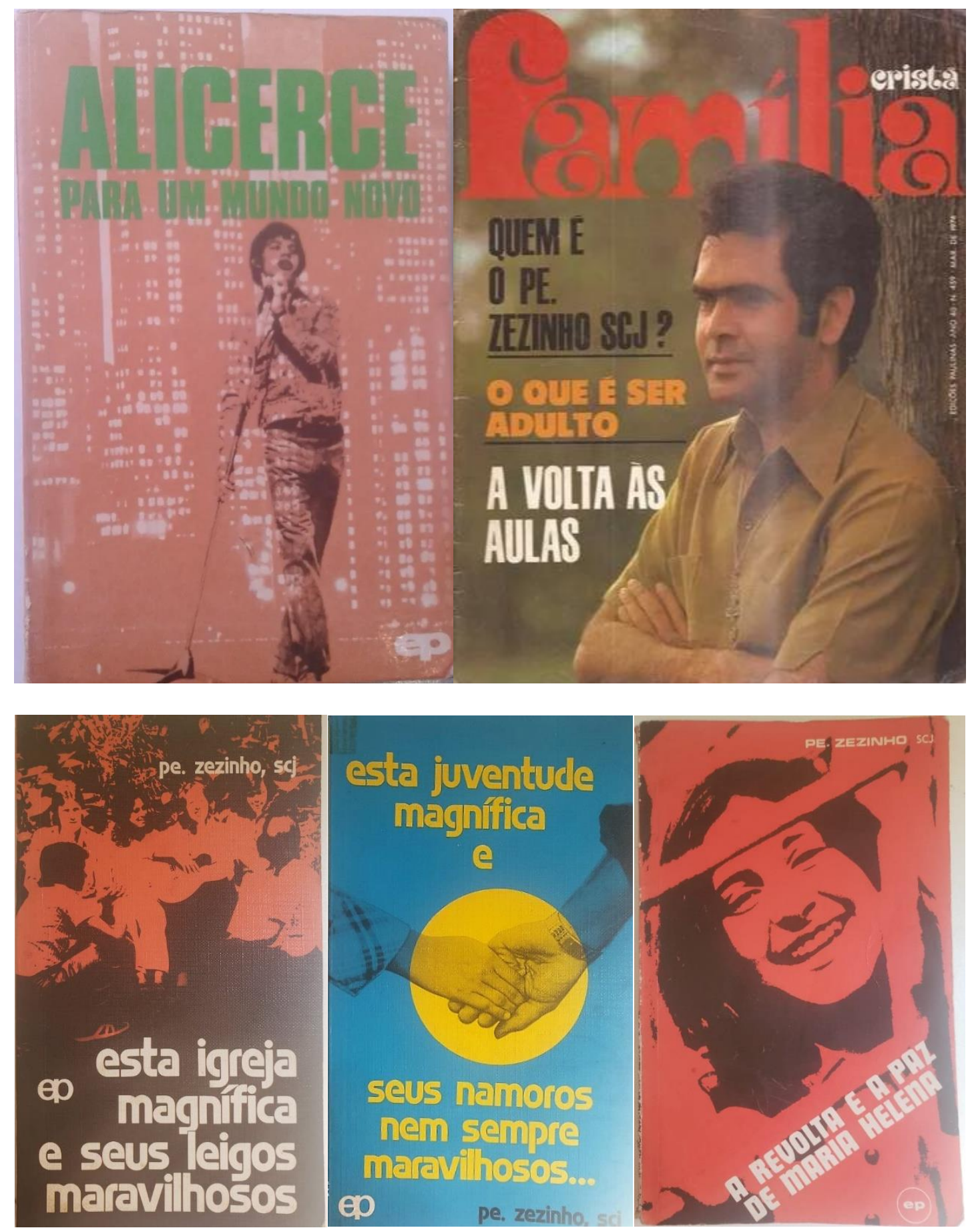

Figura 8: Pe. Zezinho, scj. Alicerce Para um Mundo Novo: A Fé Explicadas aos Jovens. São Paulo, Edições Paulinas, 1971; Revista Família Cristã, março de 1974; Pe. Zezinho, scj. Esta Igreja Magnífica e seus Leigos Maravilhosos. São Paulo, Edições Paulinas, 1976 (Compromisso, 5); Pe. Zezinho, scj. Esta Juventude Magnífica e Seus Namoros Nem Sempre Maravilhosos... São Paulo, Edições Paulinas, 1976 (Compromisso, 9); Pe. Zezinho, scj. A Revolta e a Paz de Maria Helena. São Paulo, Edições Paulinas, 1977 (Alicerce, 6). 
De acordo com o estabelecido em contrato com a editora, o autor receberia uma porcentagem maior de direitos autorais por Esta Juventude Magnífica e Seus Namoros Nem Sempre Maravilhosos... se as vendas fossem acima de cinco mil exemplares (o que de fato ocorreu) $)^{303}$. A prática de estabelecer o pagamento de acordo com as vendas era comum na editora. Em alguns casos, os autores recebiam uma porcentagem maior a partir da segunda edição ${ }^{304}$. Padre Zezinho também coordenou uma coleção a partir de 1973, O Problema É..., também sobre comportamento, cujos livros eram de autoria de Carlos Afonso Schmitt e Haroldo Galvão. Neste caso, os autores receberiam uma porcentagem de direitos autorais, e o coordenador, um terço desta ${ }^{305}$.

Alguns anos mais tarde, Haroldo Galvão envia uma carta aos paulinos decidindo rescindir os contratos dos volumes de sua autoria para a coleção. Eram eles O Problema É Droga, O Problema É Sexo e Minha Família, Meu Problema. A resposta do editor, o padre paulino Abramo Parmeggiani, é ilustrativa de como a transformação dos textos em livros passa pela mediação editorial. Sobre os dois primeiros títulos, Parmeggiani exige:

[...] para a publicação das obras em outra editora, o autor se compromete a mudar o título de cada uma. $\mathrm{O}$ autor se compromete ainda a fazer várias mudanças no texto e colocar parte nova, e também mudará quase todos os títulos de cada capítulo, de maneira que serão outros livros. Por isso, não será colocado nenhuma referência às Edições Paulinas ${ }^{306}$.

\footnotetext{
${ }^{303}$ Contrato de Edição de Esta Juventude Magnífica e Seus Namoros Nem Sempre Maravilhosos..., assinado por Carlos Vido (Edições Paulinas) e José Fernandes de Oliveira, 23.6.1976, Arquivo do Departamento de Direitos Autorais da Editora Paulus.

${ }^{304}$ Foi o caso, por exemplo, de A Humanidade Caminha Para a Fraternidade, de Paulo Evaristo Arns (Contrato de 30.11.1968, Arquivo do Departamento de Direitos Autorais da Editora Paulus).

${ }^{305}$ Contratos de 1973, Arquivo do Departamento de Direitos Autorais da Editora Paulus.

306 Carta de Abramo Parmeggiani a Haroldo Galvão, 31.8.1984, Arquivo do Departamento de Direitos Autorais da Editora Paulus. Grifos do original.
} 
Já quanto ao terceiro livro, Minha Família, Meu Problema, o editor afirma que “devemos esperar mais um pouco, porque ainda há estoque"307, fazendo supor que os outros dois já estavam esgotados, isto é, as vendas foram bem-sucedidas.

A carta de Parmeggiani levanta uma reflexão sobre as peculiaridades do objeto livro. Para além do texto (que, mesmo com mudanças, seria fundamentalmente o mesmo), os títulos dos volumes e dos capítulos são considerados essenciais por esse editor para a identificação das obras. Nesse caso em especial, porque estavam diretamente associados à coleção - O Problema $E$ - e sua publicação por outra editora prejudicaria os demais volumes, de Schmitt, que permaneceriam nas Edições Paulinas. Por outro lado, há de se levar em conta que a presença de "droga" e "sexo" nos títulos conferia um apelo polêmico $^{308}$, em termos comerciais, benéfico à editora - comprovado pelo fato de não haver mais exemplares em estoque. Quanto aos títulos dos capítulos, presume-se que fosse mais uma forma de modificar, inclusive em termos visuais (considerando o sumário etc.), a identidade do livro. Afinal, se o autor produz o texto, o trabalho do editor é de construção do livro, como expressa o título clássico de Emanuel Araújo ${ }^{309}$.

O outro autor da coleção, Carlos Afonso Schmitt, seria um dos mais populares da editora. Ele e o padre Roque Schneider, também do Rio Grande do Sul, formariam os principais nomes das coleções Encontro e De Coração a Coração, editadas pelos paulinos. Na primeira, O Importante É Cativar(-se): A Arte de Fazer Amigos e Gostar de Si (de Schmitt, 1. ed. 1979) e O Valor das Pequenas Coisas (de Schneider, 1. ed. 1977) tiveram, respectivamente, 15 e 25 edições até 1993.

\footnotetext{
${ }^{307}$ Idem.

${ }^{308}$ É justamente com metáforas do campo semântico da sexualidade que Gérard Genette se refere a uma das possíveis funções (ou valores) do título: a "sedução", tida por ele como de "eficácia duvidosa", pois "se o título é de fato o proxeneta do livro, e não de si próprio, deve-se temer e evitar que sua sedução atue demais em seu próprio benefício e em detrimento do texto" (GENETTE, Gérard. Paratextos Editoriais. Cotia, Ateliê, 2009, pp. 86-87. Grifos meus).

309 ARAÚJO, Emanuel. A Construção do Livro. Princípios da Técnica de Editoração. Rio de Janeiro/Brasília, Nova Fronteira/Instituto Nacional do Livro, 1986.
} 
Conforme iam se expandindo e atingindo o mesmo patamar das maiores editoras do país, fossem laicas ou religiosas, as Edições Paulinas passavam a contar, cada vez mais, com funcionários regulares, externos às congregações. Mas, os cargos decisivos, isto é, de editores, permaneceram nas mãos dos paulinos e paulinas. A grande quantidade de títulos publicados exigia, porém, uma distribuição do trabalho de leitura e avaliação crítica, muitas vezes realizados por autores parceiros ou membros do círculo intelectual católico em que a editora se inseria.

Segundo Iraci Maria Didoné, na década de 1980 havia um sistema para avaliação de originais na editora. O leitor crítico, membro oficial ou não da empresa, deveria preencher uma ficha de avaliação em que constavam os seguintes itens:

Público (infantil, adolescente, jovem ou adulto).

Categoria cultural a que se destina (elementar, média ou superior).

Estilo literário (claro, fluente, difícil, moralizante, conciso ou prolixo). Em que consiste a originalidade do texto?

Em que coleção você o colocaria?

Temos títulos similares? ${ }^{310}$

Pelas duas últimas questões, é possível depreender que os pareceristas deveriam ter ampla familiaridade com o catálogo da editora e com seus objetivos editoriais. Primeiro, a inclusão de mais uma faixa entre adolescentes e adultos, os "jovens" demonstra que havia um público específico a ser conquistado, justamente aquele que mais tende a se afastar da Igreja (já que as crianças e adolescentes, sob a influência dos pais, continuavam até certa idade a formação religiosa). Percebe-se, também, um esforço no sentido de se afastar do que era o catálogo da editora nas suas primeiras décadas, já que o termo "moralizante", assim como "prolixo", é usado numa conotação negativa.

\footnotetext{
${ }^{310}$ DIDONÉ, Iraci Maria. Cadernos das CEBs: Espaço de Participação? Estudo das Publicações de Edições Paulinas de Autoria e Uso das CEBs. Dissertação de Mestrado em Comunicação, Universidade de São Paulo, 1989.
} 
Além da faixa etária, nota-se que o segundo item se refere à "categorial cultural" à qual o livro é indicado ${ }^{311}$. Havia uma distinção clara na editora entre os livros mais populares e os mais eruditos que não se restringia àqueles de uso litúrgico. Se, por um lado, a Bíblia de Jerusalém apresentava-se como acadêmica, outros livros buscavam atingir um público mais amplo. Para isso, chegavam a negar seu próprio status de livro.

Tal foi o caso, por exemplo, da coleção Cidadãos do Reino, que narrava as vidas dos santos "para o homem de hoje". A "Apresentação da Coleção" assim versava:

Estamos acostumados a encarar os santos como gente "diferente" e distante de nós. Gente que viveu o Evangelho tranquilamente, resolvendo todos os problemas graças à sua amizade com Deus. Alguns até dotados de certos "poderes" com os quais realizaram fatos mirabolantes. E assim nos deixamos embalar por uma mentalidade que fez dos santos figuras distantes e estranhas à nossa realidade.

$[\ldots]$

Ao ler suas vidas e ensinamentos você também, chamado a viver em plenitude sua fé e seu amor por Deus e pelos irmãos, sentirá que o santo não é uma figura ultrapassada, que já saiu até dos altares para ser confinada aos museus. Mas que é bem atual. Está em você.

A Editora ${ }^{312}$

Seu best-seller foi o volume sobre São Francisco de Assis, de autoria do frade capuchinho Wilson João Sperandio. Publicada em Caxias do Sul pelos paulinos, a primeira edição sai em $1978^{313}$. Mesmo após os paulinos de São Paulo já possuírem uma ampla estrutura gráfica e editorial, os de Caxias do Sul continuam em atividade e mantinham relações estreitas com os círculos católicos da região. $\mathrm{O}$ contrato de $O$

\footnotetext{
${ }^{311}$ Por vezes, esse público já era definido no contrato. Antes da coleção Estudos da CNBB, os paulinos comprometem-se a publicar livros avulsos da Conferência. No contrato de um deles, sobre a semana santa, especifica-se que seria produzido "em uma edição para uso dos fiéis". Outro, Rito de Batismo de Crianças, também definia em contrato "edição para uso do celebrante" (Contratos de edição entre CNBB e Edições Paulinas, 30.11.1970. Arquivo do Departamento de Direitos Autorais da Editora Paulus. A CNBB foi representada por Aloísio Lorscheider, seu então secretário-geral).

312 JOÃO, Wilson. O Francisco que Está em Você. Vida de São Francisco de Assis Narrada para o Homem de Hoje. 5. ed. São Paulo [Caxias do Sul], Edições Paulinas, 1979. O Copyright é " 1979 by Edições Paulinas - São Paulo - SP" e no colofão consta "Composto e impressão na Gráfica de Edições Paulinas, 1979. BR 116, km 125, São Ciro, Caxias do Sul, RS”.

${ }^{313}$ O livro continuou a ser publicado pela Paulus após o fim das Edições Paulinas e, em 2014, ganhou uma versão em e-book vendida na Amazon, prova da continuidade de seu apelo comercial.
} 
Francisco que Está em Você: Vida de São Francisco de Assis Narrada para o Homem de

Hoje foi assinado ali, onde também residia o autor, com a editora representada pelo padre

Carlos Vido, em 20 de outubro de 1977 - data que pode levantar questionamentos, também, sobre se a edição de 1979 é realmente a quinta, como informa a folha de rosto, ou apenas uma segunda (já que, de fato, houve uma primeira, com capa diferente). Afinal, quanto maior o número da edição impresso na folha de rosto (ou, às vezes, mesmo na capa), mais o leitor é convencido de que aquele livro foi bem aceito pelo público e, portanto, merece ser lido também por ele.

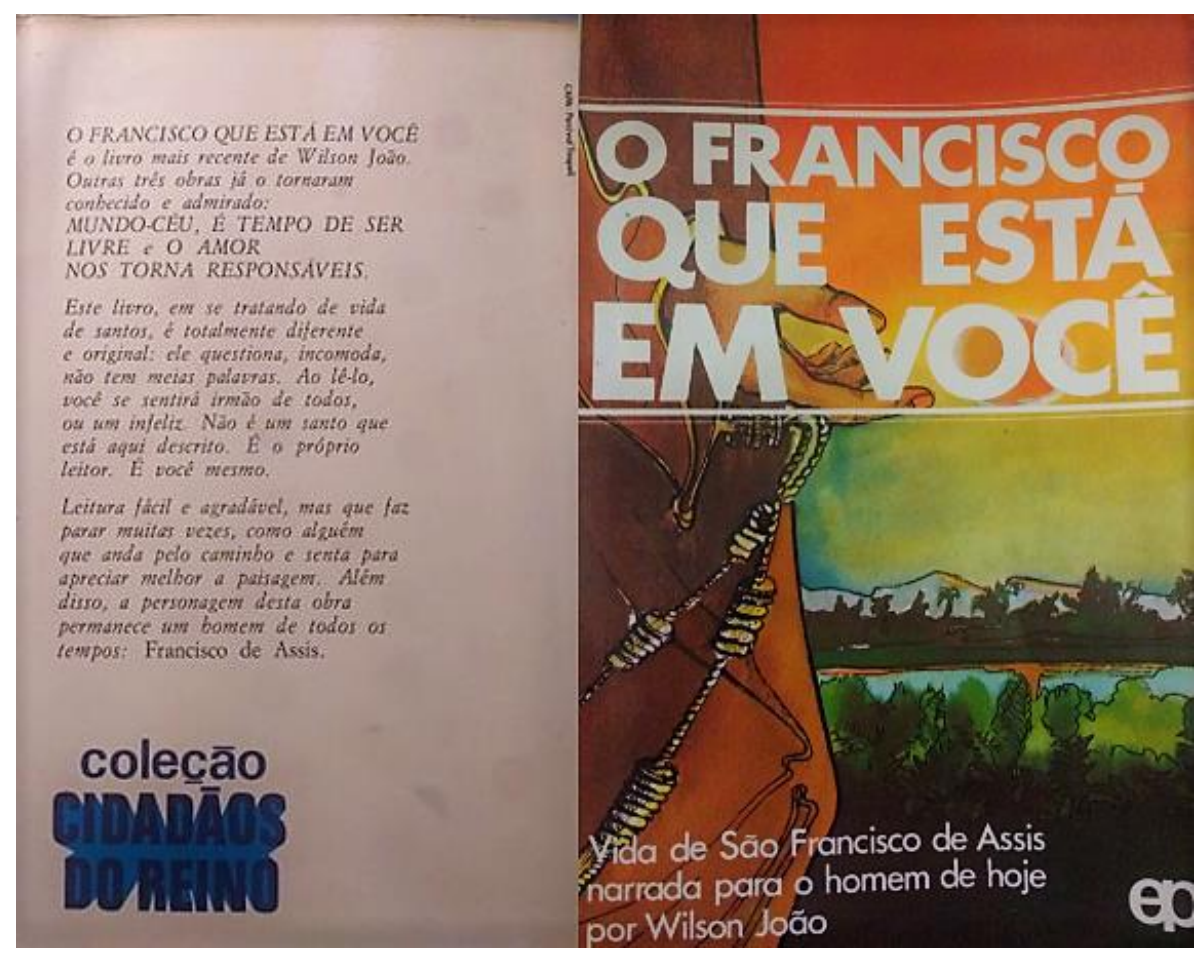

Figura 9: Quarta capa e capa de Wilson João, O Francisco que Está em Você, 1979.

A quarta capa começa afirmando que Wilson João já era um autor "conhecido e admirado" por outras obras. Depois, sobre o presente livro, buscava aproximá-lo do leitor: “em se tratando de vida de santos, é totalmente diferente e original [...]. Não é um santo 
que está aqui descrito. É o próprio leitor. É você mesmo" "314. E, por fim, garantia que se tratava de "Leitura fácil e agradável". O texto do livro aprofundava esse tom. Em uma mistura de verso e prosa com tipos e espaçamento grandes, ele se iniciava com "Lembretes":

Este livro é proibido para gente estudada, é proibido para quem conhece a vida de Francisco, é proibido para quem vê em Francisco um simples santo e poeta, é proibido para quem não quer ler aqui sua própria vida, a vida de cada dia, o santo que não é e que tem a obrigação de ser.

Nestas páginas não escrevi a vida de um santo.

Seria uma mentira se dissesse isso.

Não escrevi um livro.

Livro é algo de sério e científico ${ }^{315}$.

A estratégia para conquistar os leitores era justamente a oposta, portanto, à da Bíblia de Jerusalém, que era apresentada como o livro por excelência. Primeiro, por tratar-se do livro sagrado cristão. Mas, também pelo esforço de aproximá-la ao máximo da essência bíblica contida nos "originais", por meio de estudos especializados. A tradução direta dos "originais" a tornava, de certa forma, um pouco mais Bíblia. Já $O$ Francisco que Está em Você negava seu status de livro, que era "algo de sério e científico". O próprio título reforça os lembretes do autor: Vida de São Francisco de Assis Narrada para o Homem de Hoje por Wilson João. O efeito seria muito diferente caso a capa consistisse em:

Vida de São Francisco de Assis

Wilson João

Pois Wilson João mostrava-se ao leitor como apenas o narrador de uma história, não como o autor de um livro. Ainda menos como o autor de um livro tão sóbrio quanto

\footnotetext{
314 Idem.

${ }^{315}$ Idem, pp. 9-10.
} 
uma vida de santo. Sequer seu título de frade de capuchinho era mencionado; diferente do que ocorria, por exemplo, com Padre Zezinho. Embora seguisse, em linhas gerais, a trajetória da vida de São Francisco, cada capítulo, de duas a três páginas, mesclava em prosa e verso reflexões sobre o santo e os "problemas do homem contemporâneo", totalizando 42 capítulos em 142 páginas.

Ao final de cada seção, que poderia ser lida de forma aleatória, havia uma provocação ou pergunta ao leitor, de forma didática, mas informal. Após comentar um sonho tido pelo Papa Inocêncio III, contemporâneo de Francisco de Assis, o autor encerra o tema:

Você! E você?

Qual seu sonho?

Seu sonho é uma ilusão ou uma certeza?

É bom sonhar, mas com os pés na terra e os olhos no céu ${ }^{316}$.

O recurso de se dirigir ao leitor, propor questões e uma certa interatividade, seria uma marca de muitos dos livros mais populares da editora a partir desse momento, nos mais diversos gêneros. Alguns volumes traziam um pequeno box separado do corpo do texto, ao final dos capítulos, como nos livros didáticos, com perguntas e sugestões de reflexões, como veremos no próximo capítulo.

Wilson João também publicou outros livros sobre espiritualidade e vida pessoal na coleção Jornada, como Mundo-Céu, cuja primeira edição saiu em 1977 em Caxias do Sul. Nessa coleção, havia também obras de autores como Carlos Afonso Schmitt. João e Schmitt, além de Roque Schneider, todos pertencentes ao círculo do Rio Grande do Sul, formaram, em conjunto com Padre Zezinho, os autores mais vendidos e reeditados da editora a partir dos anos 1970.

${ }^{316}$ Idem, p. 41. 
As obras desses autores (com exceção de alguns livros de Padre Zezinho, mais catequéticos) não eram especialmente doutrinárias em relação à religião, permanecendo mais no terreno do "amor" e da "bondade". Esses livros, Paula Montero denominou como "textos semirreligiosos", que, visando um público mais amplo, "dilui a mensagem religiosa" em conceitos como "otimismo, felicidade e amor"317.

Essa tendência editorial ocorria contemporaneamente ao aumento de publicações da editora a respeito da teologia da libertação e das comunidades eclesiais de base, que, assim como interessavam ao público não religioso, estavam na ordem do dia entre os católicos. E, mesmo alguns livros como os de Carlos Afonso Schmitt e Roque Schneider, que se destinavam a uma reflexão pessoal, próxima à da autoajuda, contavam com elementos editoriais que remetiam à teologia da libertação.

O Importante É Cativar-(se): A Arte de Fazer Amigos e Gostar de Si, por exemplo, mesclava referências a $O$ Pequeno Príncipe - do título às epígrafes dos capítulos, todas de Exupéry - a "valores” cristãos. Com capítulos e parágrafos curtos como O Francisco que Está em Você, a linha narrativa tem como eixo o fortalecimento dos laços pessoais perante o que seria uma desumanização promovida pela sociedade contemporânea, às quais as críticas dirigidas eram muito sutis e genéricas, como a do trecho inicial:

\footnotetext{
"Coisa muito esquecida" nessa "terra de granito", nesse mundo conturbado massificado robotizado teleguiado poluído, manipulado pelo interesse de grupos de poder; onde não mais se tem nome nem vez, apenas se é número: mais alguém na multidão; onde se corre e se luta para sobreviver, na incerteza do pão e na certeza do
}

\footnotetext{
${ }^{317}$ MONTERO, Paula. "O Papel das Editoras Católicas na Formação Cultural Brasileira”, op. cit., p. 248.
} 
salário baixo; num mundo assim: quem ainda tem tempo para as coisas do coração?... ${ }^{318}$

E Schmitt dedica seu livro justamente às coisas do coração, ou seja, a comprometer-se com o amor, a amizade etc. Ao texto, a editora acrescenta fotografias em preto e branco da vida urbana contemporânea, creditadas à Agência Estado. Uma fila de carros, um homem escolhendo mercadorias em uma banca, um casal vestindo roupas então na moda, uma mulher vendo a cidade da janela de seu apartamento, e, a mais inusitada, uma cena da assembleia do sindicato dos metalúrgicos no Estádio da Vila Euclides, São Bernardo do Campo, em março de 1979. O recorte destaca a um homem segurando uma placa: “Greve até a vitória. Chega de exploração. Queremos 78\%”319. É possível considerar a inserção dessas imagens, pouco ou mesmo nada relacionadas ao texto, como uma forma de polemizar e modernizar o livro e torná-lo mais atraente ao leitor, em especial àquele que frequenta a livraria das Edições Paulinas no período.

O mesmo ocorreria com outra coleção dos paulinos, Juventude e Libertação, que no início da década de 1980 mesclava livros semelhantes aos do Padre Zezinho, sobre relacionamentos, ao termo "libertação", que conferia polêmica e apelo comercial. O volume de maior sucesso, Liberte-se Perdoando: A Terapia do Perdão para a Cura Interior, de Carlos Afonso Schmitt, trazia a libertação para uma chave de autoajuda. Outros volumes da coleção também tratavam de relacionamentos pessoais, como Sexo e Amor (Miguel Caviedes) e Matrimônio: Casais oK ou Solidão a Dois? (José Roberto Minervino).

Mas, o catálogo desse período também compreendia livros voltados às questões políticas. É o que veremos no próximo capítulo.

\footnotetext{
318 SCHMITT, Carlos Afonso. O Importante É Cativar(-se): A Arte de Fazer Amigos e Gostar de Si. 12. ed. São Paulo, Edições Paulinas, 1987 [1. ed. 1979]. (Encontro), p. 11.

${ }^{319}$ Idem, p. 34.
} 


\section{Capítulo 4}

\section{Um Projeto Editorial e Político (1978-1994)}

O semeador, o grão de mostarda, o fermento do pão: é do mundo material, do trabalho simples, que Jesus extrai os símiles para anunciar o advento de uma nova ordem de coisas [...]. Em matéria de sentido, Jesus sabia o que estava fazendo.

Paulo Leminski, Jesus a.C. ${ }^{320}$

\subsection{As Coleções}

Scott Mainwaring, ao estudar a "Igreja Popular", percebeu que

Relativamente poucos líderes e centros da Igreja foram de fato responsáveis pela formulação da visão política da Igreja popular. Embora os agentes pastorais na base tenham criado muitas inovações significativas, esses intelectuais e centros desempenharam papéis predominantes na sistematização e difusão de ideias. Através da literatura produzida para os agentes pastorais e de cursos ministrados em diferentes partes do país, esses líderes da Igreja popular desempenharam papel primordial na visão política da Igreja como um todo $^{321}$.

A partir de fins dos anos 1970, as Edições Paulinas publicaram uma grande quantidade de livros relativos ao pensamento teológico e às práticas pastorais da "Igreja Popular", destinados, sobretudo, a formar líderes comunitários e "agentes de pastoral". Nesses livros, havia uma proposta clara de sociedade, na qual a Igreja - tanto como

${ }^{320}$ LEMINSKI, Paulo. Jesus a.C. [1984]. In: Vida. São Paulo, Companhia das Letras, 2013.

${ }^{321}$ MAINWARING, Scott. A Igreja Católica e a Política no Brasil (1916-1985), op. cit., p. 251. 
instituição normativa quanto como comunidade de fiéis - exercia um papel bem definido. Embora houvesse uma grande diversidade dentro da Igreja considerada progressista, o que também implica uma diversidade de publicações, havia aspirações e objetivos em comum, coordenados pelos quadros e órgãos da Igreja que possuíssem algum poder executivo ou de influência religiosa e intelectual, dos bispos aos intelectuais, aí incluídos os editores. Nesse sentido, observaremos coleções $^{322}$ relativas a esse projeto publicadas pelas Edições Paulinas, visando encontrar algumas de suas linhas mestras. Se os diferentes agentes da Igreja progressista - dos padres ligados à Comissão Pastoral da Terra aos membros das comunidades eclesiais de base das periferias, por exemplo tinham objetivos e expectativas muito diversos em relação à sua atuação, enquanto católicos, em suas próprias comunidades e na sociedade brasileira como um todo, esses livros representam um esforço de proporcionar uma coerência geral a essa atuação.

A oposição da Igreja à ditadura militar vinha num crescendo desde o golpe, abarcando cada vez mais membros e setores. Mas, no último período do regime, em que ocorre uma relativa diminuição das restrições às liberdades civis, começam a ganhar força movimentos "de base", especialmente os urbanos, como as associações de bairro ou os sindicatos industriais, bases com as quais a Igreja mantinha relações muito próximas, assim como grande capacidade de influência ${ }^{323}$. Isso ocorre principalmente a partir dos últimos meses de 1978, com o fim do AI-5, e, no ano seguinte, com as grandes greves metalúrgicas no $\mathrm{ABC}$ paulista e a Reforma Partidária. Em um clima que mesclava

\footnotetext{
${ }^{322}$ Escolhemos abordar esse catálogo a partir das coleções da editora, primeiro, pela grande quantidade de títulos. Mas, também, porque a edição de coleções exercia um papel importante na empresa, não apenas pela própria distribuição e organização do trabalho editorial, como por sua força de marketing. $\mathrm{O}$ nome das coleções quase sempre aparecia em destaque na quarta capa e, nas primeiras páginas, junto à ficha catalográfica, imprimia-se uma relação dos demais volumes que o acompanhavam. Os livros estabeleciam também uma identidade visual entre si, pelos formatos e capas, e eram dispostos nas prateleiras das livrarias de acordo com as coleções a que pertenciam. Ao final desta seção 4.1, listamos todos os volumes encontrados dessas coleções (Tabela 5).

${ }^{323}$ Especialmente se considerarmos as periferias das grandes cidades, que nas décadas de 1960 e 1970 se expandiam por um intenso êxodo das populações rurais em busca dos empregos industriais. Para essa nova classe operária, a Igreja era um dos principais espaços de convivência comunitária e cultural.
} 
insatisfação econômica e social ${ }^{324}$ à esperança de abertura e transformação, a Igreja se coloca como guia das bases. Aumenta, assim, a produção de impressos que pautam as comunidades eclesiais de base e, em um nível organizativo superior, as coordenações pastorais $^{325}$; assim como suas elaborações teóricas, representadas pela teologia da libertação.

Como viemos demonstrando até aqui, as Edições Paulinas eram relativamente autônomas, o que se intensifica conforme conquistam maior espaço e status no mercado editorial e na Igreja, conseguindo ser dispensadas, por exemplo, da necessidade das autorizações eclesiásticas para as publicações (exceto para a Bíblia). Ainda assim, por sua própria filosofia de manter boas relações com a hierarquia, mantinham-se dentro dos limites implicitamente prescritos pela Igreja. Por isso, se os livros da década de 1980 tratavam de questões políticas numa chave de esquerda - novidade na editora - foi também porque a Igreja não impunha restrições rígidas quanto a isso.

Em 1978 os paulinos lançam o primeiro volume da coleção Libertação Teológica (que em 1981 mudaria seu nome para Libertação e Teologia): Teologia da Libertação, Ensaio de Síntese ${ }^{326}$, do padre chileno Segundo Galilea. No ano seguinte, o livro ganharia uma segunda edição ${ }^{327}$. A coleção publicou diversos nomes da teologia da libertação

\footnotetext{
${ }^{324} \mathrm{O}$ aumento da desigualdade imposto pela ditadura militar é verificável, por exemplo, pela progressiva queda do salário mínimo real após 1965; números sobre os quais Renato Colistete aponta, ainda, a disparidade em relação ao aumento da produtividade industrial até 1978 (COLISTETE, Renato Perim. "Salários, Produtividade e Lucros na Indústria Brasileira, 1945-1978". Revista de Economia Política, vol. 29 , n. 4, out.-dez. 2009), o que levou a um acirramento do conflito distributivo, que encontra uma via de expressão clara em março de 1979, com a primeira greve geral dos metalúrgicos, iniciada no ABC paulista. 325 Já atuantes há anos, é na segunda metade da década de 1970 que são reconhecidas e reorganizadas pela CNBB as mais importantes comissões pastorais de abrangência nacional, como a da Terra (1975), a Operária (1976) e a da Saúde (1978); o que, ao mesmo tempo que amplia, exerce um controle maior sobre elas. ${ }^{326}$ A edição original em espanhol fora lançada em Bogotá pela Indo-American Press Service, na coleção Iglesia Nueva. A mesma editora traduziu para o espanhol o volume de Frei Betto da coleção Primeiros Passos, $O$ Que É Comunidade Eclesial de Base. Não foram encontradas muitas informações sobre essa editora, mas, pelo catálogo que pôde ser identificado, ela publicou entre 1969 e 2008, sempre livros sobre teologia da libertação e práticas comunitárias na Igreja Católica. Ao que tudo indica, se não era oficial, ela possuía relações muito próximas com o Conselho Episcopal Latino-Americano. Quase todos os outros livros de Segundo Galilea em espanhol foram publicados pelas Ediciones Paulinas de Bogotá.

327 GALILEA, Segundo. Teologia da Libertação: Ensaio de Síntese. 2. ed. São Paulo, Edições Paulinas, 1979. (Libertação Teológica, 1).
} 
latino-americana, entre eles Gustavo Gutiérrez (Pobres e Libertação em Puebla), Pablo

Richard (A Igreja Latino-Americana entre o Temor e a Esperança: Apontamentos

Teológicos para a Década de 80) e Elsa Tamez (A Bíblia dos Oprimidos); teólogos progressistas europeus, como Alfredo Fierro ( $O$ Evangelho Beligerante: Introdução Crítica às Teologias Políticas) e Johann Baptist Metz (Para Além de uma Religião Burguesa: Sobre o Futuro do Cristianismo e A Fé em História e Sociedade: Estudos para uma Teologia Fundamental Prática); e brasileiros como Valfredo Tepe (Estamos Salvos: O Cristão Diante das Ideologias) e Rubem Alves (Variações sobre a Vida e a Morte: $O$ Feitiço Erótico-Herético da Teologia e Dogmatismo e Tolerância), este último protestante. Os autores eram bastante diversos, apesar de possuírem pontos de convergência: por exemplo, enquanto Segundo Galilea e Valfredo Tepe eram relativamente mais conservadores, Pablo Richard propunha um maior diálogo com Marx e Freud $^{328}$. Sobre o primeiro, Richard afirma:

A crítica marxista da religião, entendida como elemento constitutivo da prática política de libertação, e não como crítica teológica abstrata, é, para os cristãos comprometidos, um instrumento teórico, não de negação de sua fé, mas de discernimento crítico da mesma. Se o capitalismo fosse ateu, em nossa prática política não precisaria apresentar-se como necessário o ateísmo político. Mas o capitalismo não é ateu, é idólatra. Mais ainda: é uma idolatria justificada “cristãmente", de modo especial na América Latina, onde os ditadores são aceitos, o ateísmo político constitutivo da prática de libertação, chega a ser uma exigência evangélica para o povo explorado e crente ${ }^{329}$.

\footnotetext{
${ }^{328}$ Kenneth Serbin ressalta a importância da psicologia na formação do clero brasileiro desde meados do século XX. Na década de 1980, a chamada "Psicologia da Libertação" agregaria à teologia da libertação marcada por uma virada para fora do sujeito, "impelindo a Igreja da terapia à revolução" - algumas questões de gênero e de sexualidade, trazendo à tona problemas como o da violência doméstica (SERBIN, Kenneth P. Padres, Celibato e Conflito Social: Uma História da Igreja Católica no Brasil. São Paulo, Companhia das Letras, 2008, pp. 243-244). A questão, entretanto, sempre foi objeto de conflito com a hierarquia e permaneceu marginal dentro da própria Igreja progressista.

${ }^{329}$ RICHARD, Pablo. A Igreja Latino-Americana entre o Temor e a Esperança: Apontamentos Teológicos para a Década de 80. São Paulo, Edições Paulinas, 1982. (Libertação e Teologia, 19), p. 103. Grifos do original.
} 
Isto é, para Richard, o revestimento religioso das opressões políticas e econômicas não consistia em um verdadeiro cristianismo, mas em uma idolatria. Portanto, o ateísmo, como oposição, seria preferível à crença idólatra, que perpetua a situação de exploração. Esta não era uma ideia hegemônica, mesmo entre os autoidentificados com a teologia da libertação. Mas é preciso levar em conta, também, a maior liberdade de Richard, por ser leigo, em comparação com autores religiosos, isto é, padres. Richard é um teólogo chileno que se exilou na Europa após o golpe de Pinochet, em 1973, e frequentou, entre outras, a Escola Bíblica de Jerusalém. Foi membro da Cehila e do Departamento Ecuménico de Investigaciones (DEI), na Costa Rica, cujos intelectuais, como veremos mais detidamente a seguir, encontraram na categoria de "idolatria" uma forma de mesclar o pensamento cristão à crítica ao capitalismo.

Volumes como o de Segundo Galilea e o de Pablo Richard eram editados na coleção Libertação e Teologia, buscando a popularização desses pensamentos. Eram pouco extensos (um com 80, o outro com 120 páginas), e as escassas notas de rodapé, quando havia, eram movidas para o fim dos capítulos; o corpo do texto era impresso em tipos grandes e as capas eram ilustradas ${ }^{330}$ (Figura 10). Iraci Maria Didoné afirma que os editores escolhiam um corpo maior para os textos de livros mais populares para "facilitar a leitura dos semianalfabetos" 331 . Esses livros, entretanto, parecem ser destinados a um público de escolaridade média, não acadêmico, mas que conhecesse determinados conceitos, sobretudo de teologia e sociologia ${ }^{332}$.

\footnotetext{
${ }^{330}$ Nesse sentido, muito semelhante era a coleção Tempo de Libertação, também dos paulinos, que trazia nomes conhecidos da teologia da libertação (Segundo Galilea, Rubem Alves, entre outros), em livros destinados não à reflexão de teólogos, mas ao público geral. Seu primeiro volume, por exemplo, chamavase Por Que a Igreja Critica os Ricos? (autoria de Juan Leuridan e Guilhermo Múgica, 1982).

${ }^{331}$ DIDONÉ, Iraci Maria. Cadernos das CEBs: Espaço de Participação? Estudo das Publicações de Edições Paulinas de Autoria e Uso das CEBs, op. cit.

332 Conforme comentamos, na introdução, a respeito das anotações marginais sobre alguns termos realizadas por antigos leitores dos exemplares aos quais tivemos acesso.
} 


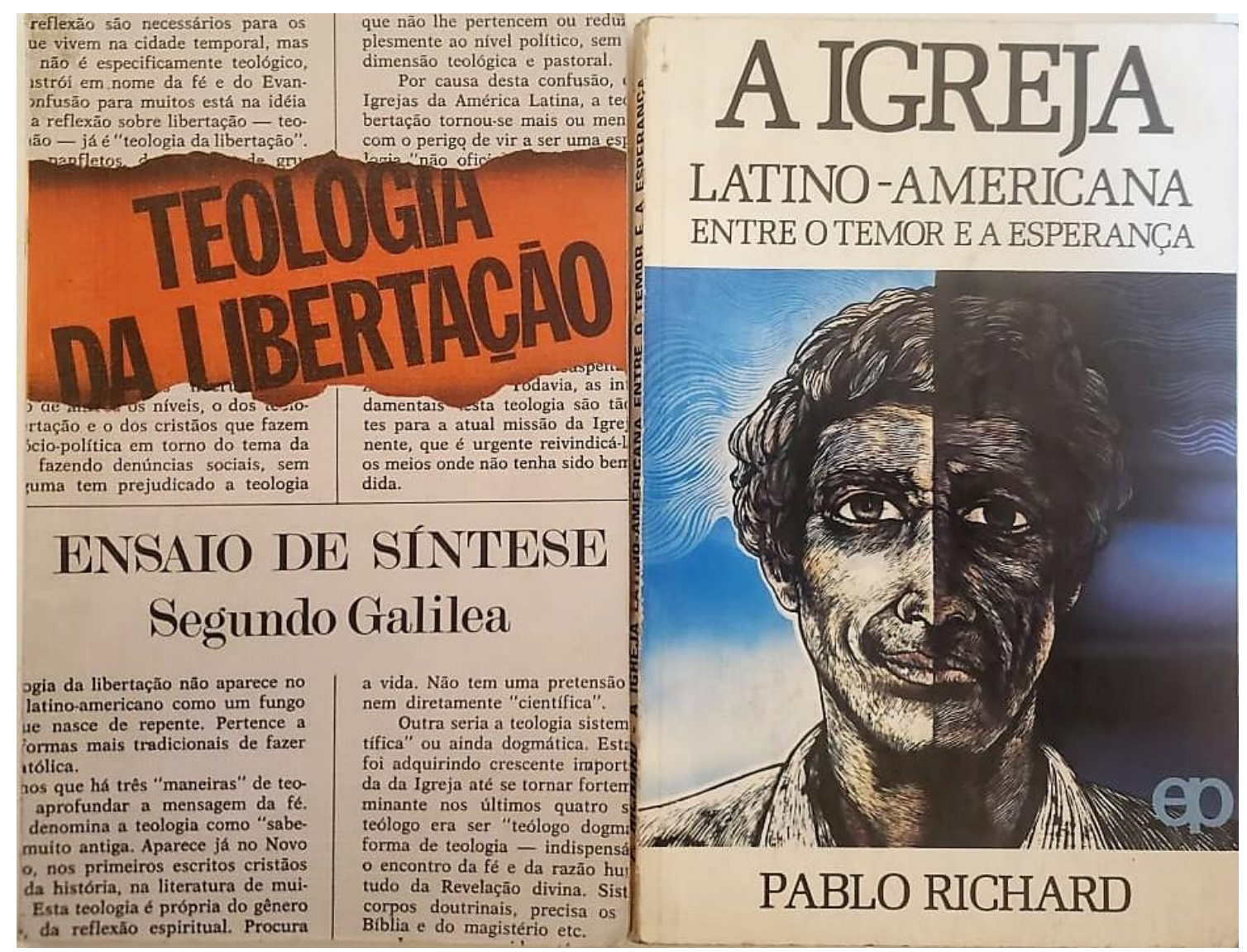

Figura 10. Volumes da coleção Libertação e Teologia

Um pouco distinto era o formato das coletâneas publicadas pela mesma coleção. A Igreja que Surge da Base, de 1982, era fruto do IV Congresso Internacional Ecumênico de Teologia, promovido pela Associação Ecumênica de Teólogos do Terceiro Mundo em Taboão da Serra, SP, em 1980. Esse volume de 360 páginas, organizado por Sérgio Torres, trazia textos de Gustavo Gutiérrez, Enrique Dussel, Luís Eduardo Wanderley (cientista social ligado à PUC-SP), Jon Sobrino, Carlos Mesters, Leonardo Boff e outros, permeados por notas de rodapé, bibliografias e um prefácio de Frei Betto. De forma inusitada na editora, uma das falas de abertura do evento é reproduzida no original em francês, sem tradução, o que indicava ser o volume destinado a um público mais restrito ${ }^{333}$. Mais tarde,

333 TORRES, Sérgio (org.). A Igreja que Surge da Base. Eclesiologia das Comunidades Cristãs de Base. São Paulo, Edições Paulinas, 1982. (Libertação e Teologia, 11). 
alguns dos volumes da Libertação e Teologia continuaram sendo reimpressos pela Paulus, mas não foram encontrados novos títulos após 1988, data até a qual teve cerca de 29 títulos, sendo o de maior sucesso (com mais edições), o Ensaio de Síntese de Galilea.

Além da coleção Libertação e Teologia, os paulinos publicaram diversas coleções com estudos, sob uma perspectiva católica - ou, por vezes, ecumênica - progressista, a respeito não apenas da teologia da libertação, mas também sobre as práticas eclesiais contemporâneas, especialmente as comunidades eclesiais de base. Havia, por exemplo, as coleções Estudos \& Debates Latino-Americanos e Pesquisa \& Projeto, também editadas pelos paulinos. As duas privilegiavam as premissas teóricas e políticas da teologia da libertação; destacavam a formação acadêmica de seus autores e contavam com notas de rodapé e extensas bibliografias.

Estudos \& Debates Latino-Americanos publicava obras de pesquisadores brasileiros e de outros países latino-americanos. Muitos dos volumes da coleção eram produzidos em edição conjunta com a Cehila (Comissão de Estudos de História da Igreja na América Latina) ou de sua autoria. De Enrique Dussel ${ }^{334}$, a coleção publicou, em 1985, os quatro tomos de Caminhos de Libertação Latino-Americana. Assim como a Cehila (e a Igreja progressista em geral) intentava formar um projeto ecumênico, isto é, em diálogo com outras denominações cristãs, a coleção lança em 1984 também um volume de Antonio Gouvêa Mendonça, O Celeste Porvir: A Inserção do Protestantismo no Brasil. Em geral, a coleção editava teses e dissertações de autores ligados à Cehila ou com perspectivas semelhantes às desta.

\footnotetext{
${ }^{334}$ Filósofo argentino, exilado desde 1975 no México, ligado à teologia da libertação, ficou conhecido pela elaboração da "filosofia da libertação". Em 1989, os paulinos editaram também sua obra História da Igreja Latino-Americana (1930-1985), sem coleção. Em 1988, a coleção Libertação e Teologia lança um estudo de Roberto S. Goizueta sobre Dussel: Metodologia para Refletir a Partir do Povo: E. Dussel e o Discurso Teológico Norte-Americano.
} 
O Pensamento Cristão Revolucionário na América Latina e no Caribe (1960-

1973): Implicações da Teologia da Libertação para a Sociologia da Religião foi fruto do doutorado em Estudos Latino-Americanos defendido na UNAM (Universidade Autônoma do México) por Samuel Silva Gotay em 1978. Lançado na coleção Estudos \& Debates Latino-Americanos em 1985, o livro trazia na quarta capa uma biografia acadêmica de seu autor ${ }^{335}$, que, com extensas bibliografias e notas de rodapé, via na Teologia da Libertação latino-americana uma resposta à "crise teórica" da teologia europeia, por meio da valorização da história, da ciência e da política. Após discorrer sobre os temas da "recuperação do sentido histórico", "redescoberta da dimensão política da fé", "fé e ciência" e "fé e ideologia", que desembocariam em uma "ética cristã de libertação", com a "historicização dos valores e politização da ética"336, na conclusão Silva Gotay estabelece um diálogo entre a Teologia da Libertação e os estudos sobre o cristianismo primitivo de Friedrich Engels, sublinhando o potencial revolucionário dos cristãos latinoamericanos contemporâneos, já que, conclui o autor, "o amor ao próximo e a revolução na América Latina podem ser uma mesma coisa", pois "a revolução é o amor"337.

Esse é um dos poucos títulos das coleções das Edições Paulinas que discutem abertamente revolução e luta de classes. Tais ideias podiam ter espaço nos livros acadêmicos, destinados a estudos teóricos, o que não ocorria nas obras para formação de lideranças pastorais e comunitárias. Ainda assim, publicações como a de Silva Gotay representam a diversidade de leituras possíveis para os católicos interessados na Teologia da Libertação e nas relações entre a fé e o pensamento de esquerda.

\footnotetext{
335 “O Dr. Samuel Silva Gotay é graduado nas universidades de Porto Rico, de Yale (USA) e da UNAM do México, onde realizou estudos de psicologia, teologia e estudos latino-americanos. Atualmente é professor de Estudos Latino-americanos na Faculdade de Ciências Sociais da UPR e coordena o projeto de História Social da Igreja no Caribe para o CEHILA e para o Instituto de Estudos do Caribe dessa Faculdade". SILVA GOTAY, Samuel. O Pensamento Cristão Revolucionário na América Latina e no Caribe (1960-1973): Implicações da Teologia da Libertação para a Sociologia da Religião. São Paulo, Edições Paulinas, 1985. (Estudos \& Debates Latino-Americanos, 15).

336 Idem.

${ }^{337}$ Idem, pp. 333-334.
} 
Outra coleção semelhante, Pesquisa \& Projeto, era formada por obras teóricas, teológicas e filosóficas, e a maioria era traduzida, fosse do inglês, espanhol ou francês, além de alguns volumes originalmente escritos em português, como $O$ Direito dos Pobres, de autoria do jurista da PUC-SP Wagner Balera. Outro volume foi As Armas Ideológicas da Morte, de Franz Hinkelammert. Teólogo e economista alemão, Hinkelammert residiu no Chile e na Costa Rica, e seu pensamento mesclava a crítica do capitalismo a elementos teológicos, sobretudo pelas ideias de fetiche e idolatria. Como vimos mais acima no livro de Pablo Richard, a idolatria do capital é uma categoria frequente na teologia da libertação. Com Richard e Hugo Assman ${ }^{338}$, Hinkelammert fundou na Costa Rica o Departamento Ecuménico de Investigaciones (DEI), em 1976, que contava ainda com a colaboração de outros teólogos, como Jung Mo Sung ${ }^{339}$. A coleção Pesquisa \& Projeto contava também com obras de François Houtart, que teve obras traduzidas em espanhol pelo DEI.

Lançado originalmente em espanhol em 1977, As Armas Ideológicas da Morte, de Franz Hinkelammert, saiu pelas Edições Paulinas em 1983. A capa exibia uma multidão de pessoas visualmente padronizadas, que formavam uma caveira (cf. Figura $11)^{340}$, remetendo apenas à questão da morte, enquanto a capa original tinha mais elementos, com uma caveira vestida de Tio Sam, cuja boca era formada pelo trocadilho in gold we trust, segurando uma cruz feita de dólares. A edição brasileira perdeu, ainda, o subtítulo: El Discernimento de los Fetiches: Capitalismo y Cristianismo, que tampouco

\footnotetext{
${ }^{338}$ Pela coleção Teologia e Libertação da editora Vozes, Hinkelammert publicou em 1989, em conjunto com Hugo Assman, outro livro sobre tema relacionado, A Idolatria do Mercado.

339 A escolha da Costa Rica como sede do DEI, que reuniria exilados oriundos de diversos países latinoamericanos, deveu-se, segundo Pablo Richard, tanto à sua localização geográfica, entre o Sul e o Norte, quanto a suas características políticas (a Costa Rica não tem exército nacional, por exemplo). Cf. PÉREZ, Claudio Jesús \& MURPHY, John W. "El Trabajo del Departamento Ecuménico de Investigaciones y América Latina". Comunicación, Cultura y Política. Revista de Ciencias Sociales, n. 4, jul.-dez. 2011, p. 13.

${ }^{340} \mathrm{Na}$ capa consta a assinatura do artista, cujo nome não foi identificado. Não há, dentro do livro, crédito a essa ilustração. O fato de ser assinada, entretanto, leva a supor que o autor não era membro das Edições Paulinas, já que quase todas as capas da editora eram elaboradas pelos próprios paulinos e paulinas e não eram assinadas.
} 
é reproduzido no interior do livro. A obra é dividida em três partes. A primeira aborda a “fetichização das relações econômicas", partindo da crítica de Marx ao caráter fetichista da mercadoria e, consequentemente, do dinheiro, passando por Max Weber e chegando até "o fetichismo feliz de Milton Friedman"341. Já a segunda parte abarca uma reflexão teológica sobre "O reino da vida e o reino da morte: vida e morte na mensagem cristã", para que, na terceira e última parte, sintetize as reflexões em "o nexo corporal entre os homens: vida e morte no pensamento católico atual". Nesta, Hinkelammert faz uma análise original da política reacionária a partir da ideia de "antiutopia", que tem na imagem da crucificação seu centro. Para ele, conforme ocupou posições de poder, o cristianismo substituiu a "boa nova" da vida e da ressureição pela da morte e da crucificação. Ele vê uma continuidade na tradição cristã "antiutópica", presente na perseguição medieval aos movimentos messiânicos, no nazismo e no fascismo (com seus “movimentos de massa antiutópicos") e nas ditaduras latino-americanas contemporâneas. A essa tradição violenta não é negado o caráter cristão; ela faria uso, entretanto, de uma espécie de cristianismo manipulado, de forma a taxar seus inimigos (“os movimentos sociais") de anticristo, para, assim, crucificá-los.

Ao dedicar capítulos para criticar o pensamento ultraliberal de Friedman e de seu antecessor Hayek, Hinkelammert via uma ligação intrínseca entre a “idolatria” do mercado desregulado ao pensamento autoritário antiutópico - concepção que lembra, ainda, a tese do "fim da história", a antiutopia neoliberal que seria elaborada textualmente por Francis Fukuyama em 1992. A ideia de Hinkelammert sobre o antiutopismo ainda ressoa:

Aparece a alusão a um novo Terceiro Reich, uma nova edição do milênio nazista. Sonha-se com um país no qual ninguém mais sonhe.

341 HINKELAMMERT, Franz. As Armas Ideológicas da Morte. São Paulo, Edições Paulinas, 1983. (Pesquisa \& Projeto, 6). 
Coloca-se a esperança numa sociedade na qual ninguém tenha mais esperança. Sente-se uma libertação no caso de não haver mais nenhum movimento de libertação. A inversão do cristianismo antiutópico invade a própria esperança utópica. Promete um futuro no qual o utópico seja erradicado em nome dos paraísos do pensamento utópico. A vinda do Messias muda-se também em seu contrário: vem para destruir, derrotar e lançar no abismo todos os movimentos messiânicos. Messias agora é libertação do messianismo, como o céu é a libertação do corpo de sua corporeidade e sua sensualidade ${ }^{342}$.

Ao paraíso utópico, em que se come pão e se bebe vinho, Hinkelammert contrapõe o céu antiutópico, em que não há necessidade de pão e vinho. Sendo o cristianismo antiutópico a arma ideológica da morte, a conclusão óbvia a que chega ao autor é que a ele só se pode contrapor um cristianismo utópico, "orientado para a vida", a Teologia da Libertação, que inclui uma "dignificação cristã da vida real”, isto é, a valorização de um paraíso terreno, onde haja pão e vinho. Assim a obra é encerrada:

Trata-se de uma correspondência que não reduz nem o marxismo ao cristianismo, nem o cristianismo ao marxismo. A especificidade do marxismo é a práxis, que desemboca na transcendentalidade interior à vida real. A especificidade cristã é a esperança nas possibilidades dessa práxis além da factibilidade humana calculável. A ponte comum é a vida real e material como a última instância de toda a vida humana ${ }^{343}$.

Como afirmamos, as coleções Libertação e Teologia, Estudos \& Debates LatinoAmericanos e Pesquisa \& Projeto eram destinadas a reflexões teóricas, na maioria das vezes restritas a especialistas. No entanto, essa ideia de paraíso terreno, isto é, de um materialismo que não é contraditório com a visão católica do mundo, seria um elemento comum à teologia da libertação e à prática da Igreja progressista. Da mesma forma a crítica à religião conservadora, tida como ideologia, isto é, como justificativa de um sistema econômico, social e político, em contraposição à teologia "libertadora".

\footnotetext{
${ }^{342}$ Idem, pp. 277-278.
}

${ }^{343}$ Idem, p. 339. 


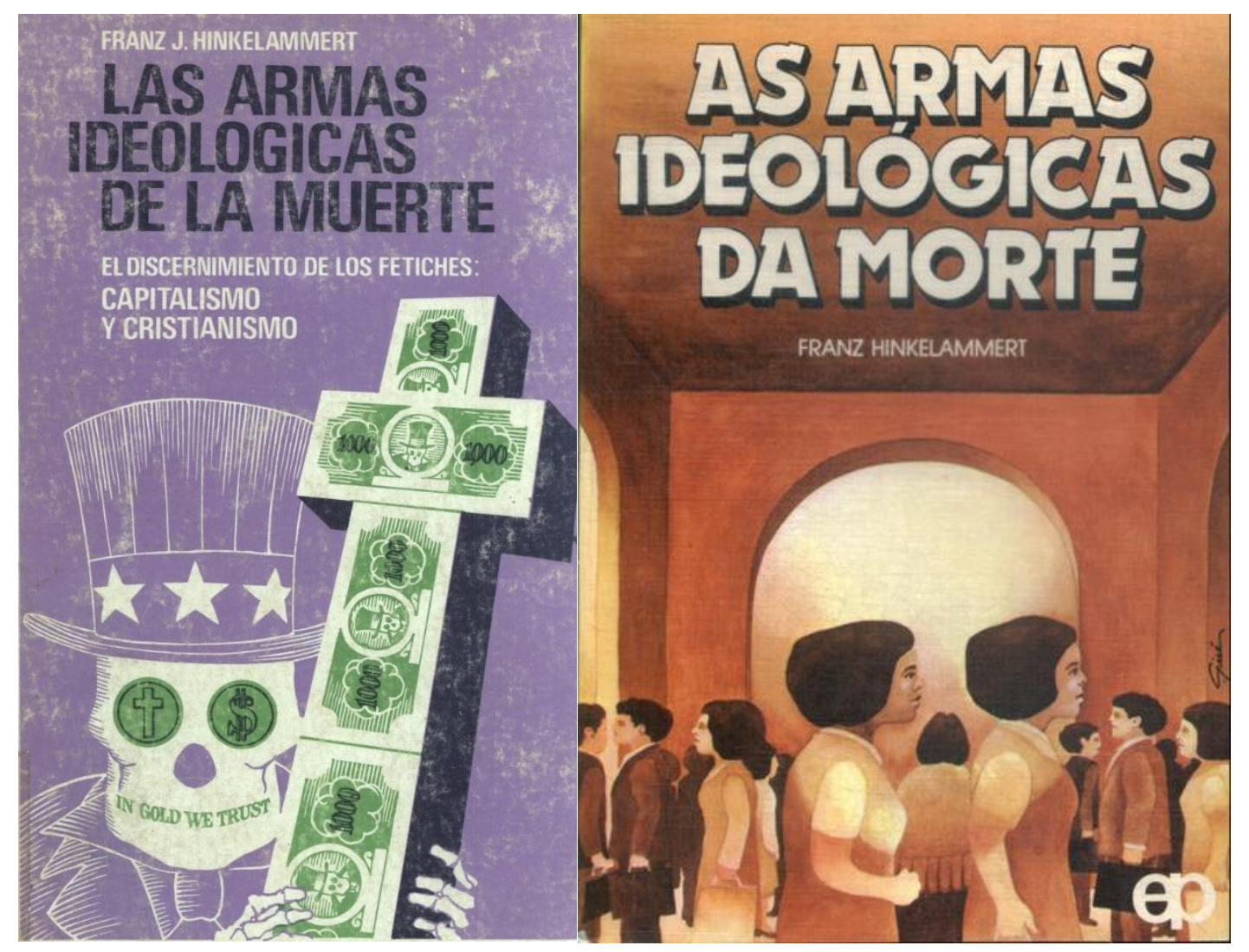

Figura 11. À esquerda, Franz Hinkelammert. Las Armas Ideologicas de la Muerte. El Discernimento de los Fetiches: Capitalismo y Cristianismo. San José, Editorial Universitaria Centroamericana, 1977. À

direita, a versão brasileira: As Armas Ideológicas da Morte. São Paulo, Edições Paulinas, 1983.

(Pesquisa \& Projeto, 6).

Outra coleção publicada pelos paulinos, Cadernos de Base ${ }^{344}$, se destinava ao uso direto dos membros das CEBs. Como comentamos no capítulo anterior, grande parte desses "folhetos" eram produzidos por dioceses e arquidioceses. Em uma linguagem mais simplificada, alguns de seus volumes - como o vol. 5, Bate-Papo sobre Política II: Como

\footnotetext{
${ }^{344}$ No período, havia muitas coleções de diversas editoras com esse mesmo título e formato, que consiste em pequenas brochuras, muitas vezes grampeadas, com a capa impressa no mesmo papel do miolo (muitas vezes possuem menos de cinquenta páginas, motivo pelo qual os arquivistas costumam considerá-los folhetos, e não livros). Uma das pioneiras surgiu no Chile, durante o governo de Salvador Allende, e foi elaborada por Marta Harnecker e Gabriela Uribe sob o nome de Cuadernos de Educación Popular. Na década de 1980, o modelo foi bastante replicado no Brasil. Coleções distintas, mas com o mesmo título, foram publicadas pela Vozes e pela Global, por exemplo. Nas Edições Paulinas, além da Cadernos de Base, havia também na década de 1980 a coleção Cadernos Bíblicos, com traduções da francesa Cahiers Evangile, publicada pela Éditions du Cerf, que trazia pequenos estudos em volumes entre oitenta e cem páginas. A Cadernos Bíblicos, porém, não chegava a ser uma coleção para popularização da Bíblia ou para incentivar sua leitura nas comunidades eclesiais de base, diferentemente das coleções que abordaremos mais adiante, na seção 2 deste capítulo.
} 
Funciona a Sociedade, de autoria da Arquidiocese de Vitória (1982) - eram em formato de história em quadrinhos. Isto é, diferente da maioria das obras dedicadas ao mesmo público leitor, não possuíam apenas ilustrações em meio aos textos. Os quadrinhos desse título, por exemplo, afirmam que os trabalhadores sustentam a sociedade, já que ela é baseada no "processo de produção" que depende do trabalho humano. Critica, ainda, aqueles que pregam a "ideologia dominante", entre os quais há também religiosos: em uma espécie de caricatura, um padre situado em um plano muito acima dos fiéis prega que "os pobres sempre existirão". Havia, ainda, uma seção de perguntas, impressas em letras muito grandes e em caixa alta que ocupavam toda uma página (o caderno tem o formato A5):

Agora, vamos responder:

- Para que serve o Estado em nossa sociedade?

- Para que serve a ideologia dominante?

- Você conhece algum trabalhador com ideia de patrão na cabeça? Conte pra nós! ${ }^{345}$

Nesse tipo de publicação, os autores acreditam ser necessário explicar tudo, meticulosamente, aos leitores, que são tratados de forma quase infantilizada. O texto de apresentação afirma:

A novidade [em relação ao Bate-Papo sobre Política I] é que o caderno é apresentado em forma de estória em quadrinhos. Achou-se que assim ele poderia ajudá-lo a entender melhor o assunto de que trata. Mas para que ele seja bem aproveitado, é preciso que sua leitura seja feita sempre tentando ligar o texto escrito ao desenho do quadrinho.

$[\ldots]$ BOA REUNIÃO, BOM DEBATE $\mathrm{e}$ BOM TRABALHO! ${ }^{346}$.

\footnotetext{
345 ARQUIDIOCESE DE VITÓRIA. Bate-Papo sobre Política II: Como Funciona a Sociedade. Desenhos de Fabiano. São Paulo, Edições Paulinas, 1982. (Cadernos de Base, 5), p. 28.

${ }^{346}$ Idem.
} 
Já as publicações da seção feminina da editora eram mais relacionadas à catequese e à prática pastoral que à reflexão teológica, restrita aos homens. A partir de 1976, as irmãs paulinas editaram a coleção Igreja Dinâmica, cujos livros abordavam e instruíam a organização dos grupos pastorais de juventude. Um dos primeiros volumes, Panela de Opressão. Juventude: da Opressão do Cativeiro à Libertação, de autoria de Walmir Fernandes Brandão (padre, título que não figura na capa do livro), tinha como público almejado as comunidades de jovens, especialmente seus líderes (ou seja, um público não acadêmico, mas estudante), na chave da Teologia da Libertação. Seguia o mesmo esquema organizativo de obras como O Francisco que Está em Você e as do Padre Zezinho (cf. Capítulo 3), mas a maioria dos capítulos não tratava de espiritualidade individual ou de relacionamentos, e sim do posicionamento dos jovens perante a realidade econômica, política e social. A capa, reproduzida abaixo, inseria o mapa da América em uma panela de pressão aquecida pelo fogo da guerra, da violência, da fome e de outras agruras que, sugeridas por letras embaralhadas, parecem ser muitas. 


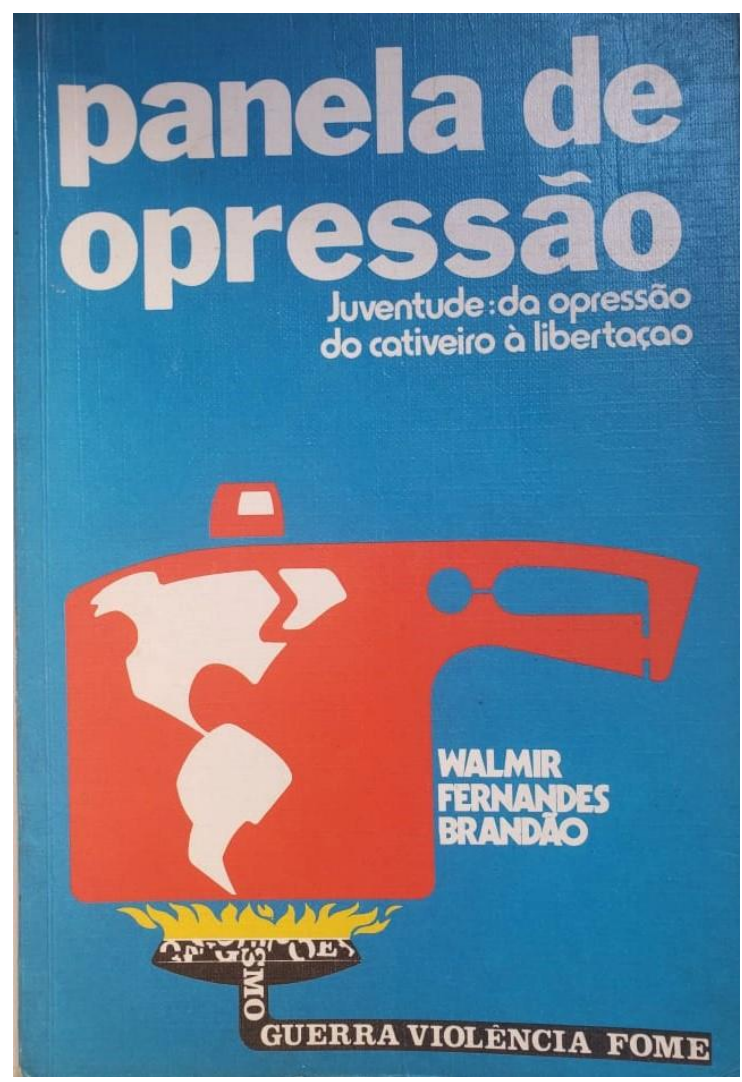

Figura 12: Walmir Fernandes Brandão. Panela de Opressão. Juventude: da Opressão do Cativeiro à Libertação. São Paulo, Edições Paulinas, 1979. (Igreja Dinâmica).

O livro se dividia em 21 capítulos curtos, totalizando 88 páginas, das quais sete eram de ilustrações relacionadas aos títulos dos capítulos, em linguagem coloquial e em si já muito eloquentes sobre as temáticas abordadas:

1. Um continente esmagado

2. A dignidade do homem

3. Pobreza e miséria

4. Mas onde está o meu irmão

5. O servo de Javé

6. Deus é o libertador do terceiro mundo

7. Ter mais ou ser mais

8. As guerras

9. Corrida armamentista

10. Resposta à corrida armamentista

11. Homem máquina e massificação

12. Diálogo

13. Liberdade

14. Quando o AMOR é mais forte

15. Pra que religião? 

16. Família
17. A paz
18. Meus 18 anos
19. Curtindo uma legal
20. A você meu irmão de ideal
21. O latifúndio ${ }^{347}$

A estrutura de todos os capítulos era semelhante, formada por três seções que se repetem. Tomemos, por exemplo, o 3, "Pobreza e Miséria". A primeira seção, "Situação do Mundo", reproduz uma citação de alguma obra religiosa. Neste capítulo 3, a citação é de um trecho da exortação apostólica de Paulo VI sobre a evangelização no mundo contemporâneo, Evangelii Nutiandi, de 1975. Na reprodução, os editores grifam o termo "libertação" em caixa-alta. Já a segunda seção, "Dados da realidade", começa por mais uma citação, desta vez não religiosa, mas de análise social. No caso, um parágrafo sobre a diferença do crescimento econômico entre o mundo "em vias de desenvolvimento" e os países desenvolvidos, extraídas de A Dependência Político-Econômica da América Latina, obra coletiva de cientistas sociais ${ }^{348}$. Então, inicia-se o texto de Walmir Fernandes Brandão, em forma de versos rimados, com estrofes numeradas:

1. Analfabeto, doentes, explorados, São tidos por inúteis rebotalhos, Sem emprego, sem sustento e condenados, A não viver, mas a vagar sem os trabalhos!

2. A "Política" que visa o bem comum, Beneficia uma classe dominante, Exclui o povo sem favor algum, Dos seus direitos num agir tão revoltante! $!^{349}$

\footnotetext{
347 BRANDÃO, Walmir Fernandes. Panela de Opressão. Juventude: da Opressão do Cativeiro à Libertação. São Paulo, Edições Paulinas, 1979. (Igreja Dinâmica), p. 87. Os sumários das publicações das Edições Paulinas costumavam situar-se ao final dos livros.

${ }^{348}$ A autoria é de Hélio Jaguaribe, Aldo Ferrer, Miguel S. Wionczek e Theotônio dos Santos. Publicado em São Paulo, pela Loyola, em 1976. Em Panela de Opressão, consta apenas o título da obra, sem demais indicações bibliográficas. A ausência de bibliografia é uma constante nos livros das Edições Paulinas destinados ao uso das comunidades.

349 BRANDÃO, Walmir Fernandes. Panela de Opressão. Juventude: da Opressão do Cativeiro à Libertação, p. 23.
} 
A forma acelera a leitura e torna a página "arejada", com pouco texto, o que é intensificado pela intercalação de ilustrações. Depois de doze estrofes semelhantes a estas, a última seção, "Dinâmica: debate em grupo", sugere questões para discussão e atividades a serem realizadas pela comunidade:

1 - Por que o divisor das águas - o mais sério problema dos tempos atuais - é a carência de Justiça no mundo?

2 - Por que se diz que a miséria é a poluição de todas as poluições?

3 - A raiz de todos os males é o pecado e as consequências do pecado: a fome, as doenças, as misérias, as estruturas iníquas, as injustiças sociais, a subalimentação, o desemprego, a vida dos marginalizados etc. Que pode fazer você para transformar essa realidade? Como fazer? Que é conscientizar-se?

4 - Represente de alguma forma por escrito, em verso ou em prosa, seus pensamentos sobre a pobreza e a miséria.

5 - Faça uma representação teatral sobre a fome no mundo ${ }^{350}$.

O livro, portanto, não apenas sugere os temas a serem debatidos pela comunidade de jovens como também a própria dinâmica dos encontros. Como ocorre com livros didáticos, é pouco provável que os participantes seguissem todas as atividades; mas, se adotavam o livro, pelo menos um dos assuntos por ele levantado seria discutido, ainda que fosse para criticar a abordagem do autor.

Essa estrutura, em que perguntas e propostas de atividades se seguem ao texto principal, era constantemente repetida nos livros das Edições Paulinas. Na mesma coleção Igreja Dinâmica, outro volume, de 365 páginas, utilizaria o mesmo recurso de questionários para "estudo", mas com um texto principal muito mais longo e aprofundado. Trata-se de Juventude: O Grande Desafio, de Pe. Jorge Boran C.S.sp. ${ }^{351}$, publicado em 1982, cujo objetivo não era o uso cotidiano pelos grupos de jovens, mas a formação de líderes e agentes pastorais para atuar nesses grupos, também na corrente da

\footnotetext{
${ }^{350}$ Idem, p. 30, grifos do original. O salto nas páginas ocorre por um erro de composição: a dinâmica sugerida para o capítulo 3 está ao final do capítulo 4 , e vice-versa.

${ }^{351}$ Assim consta o nome do autor na capa do livro. "C.S.sp." refere-se à Congregação do Espírito Santo.
} 
libertação. A capa, uma colagem que remete à estética das revistas, incorpora inúmeros elementos que se busca associar à juventude: além de um Cristo e do papa João Paulo II, há grupos de jovens conversando, portando livros e cantando, cenas de guerra, trabalhadores rurais, uma fábrica, um cantor em um show e um jogador de futebol.

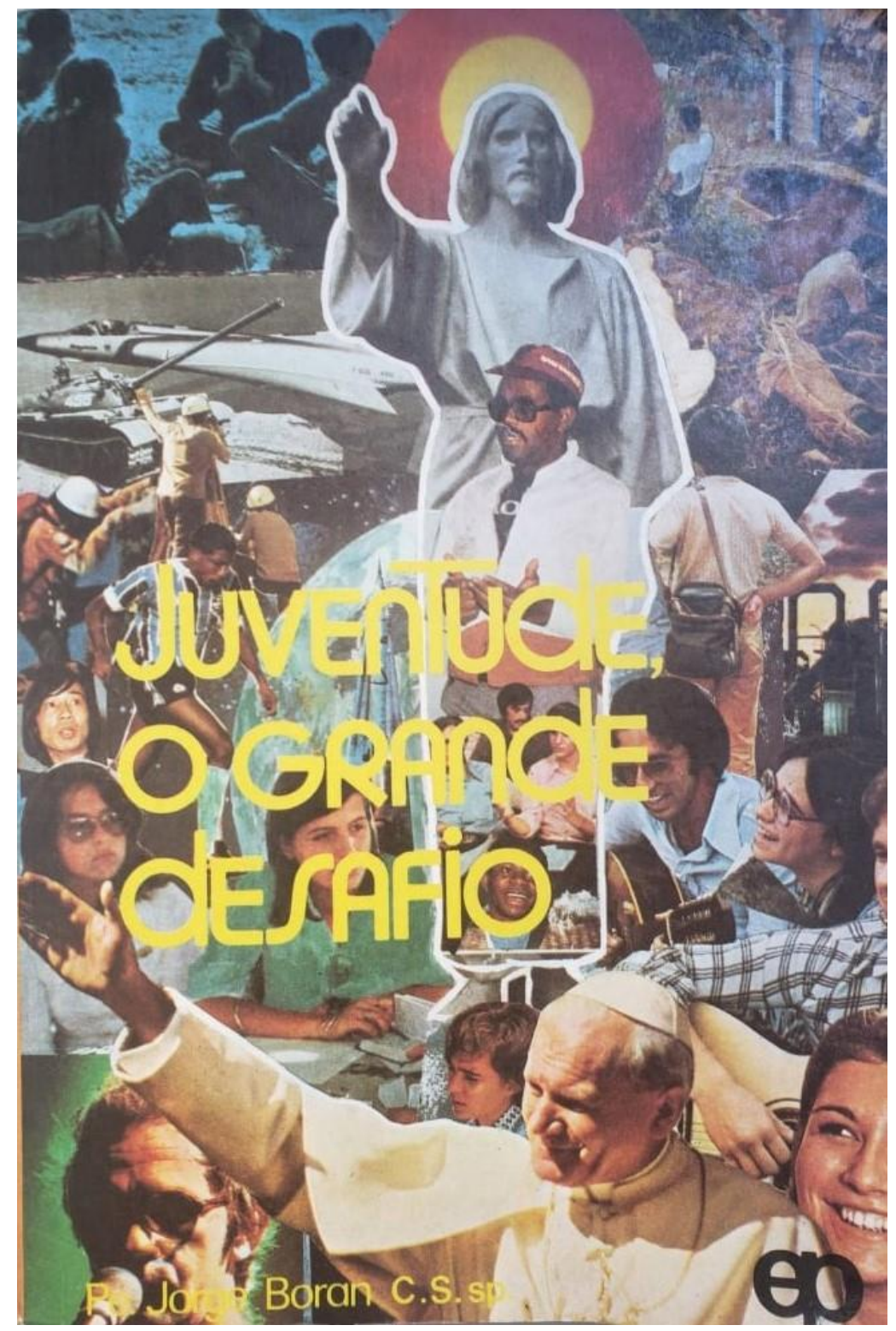

Figura 13: BORAN C.S.sp., Pe. Jorge. Juventude: O Grande Desafio. São Paulo, Ediçães Paulinas, 1982. (Igreja Dinâmica). Capa de C. Facchin.

O status que se busca conferir a essa obra é bem distinto do Panela de Opressão, o que se verifica em virtude dos paratextos que lhe conferem autoridade. Antes de uma 
apresentação de Paulo Evaristo Arns (com um cabeçalho grafado "Gabinete do Cardeal Arcebispo de São Paulo", que lhe dá aparência de documento oficial), os agradecimentos do autor são destacados na primeira página do livro e dirigem-se a nomes bem conhecidos da Igreja e dos movimentos sociais. Tendo em mente que o autor, Jorge Boran, era, segundo a quarta capa, “Assessor nas coordenações da Pastoral da Juventude da Região Sul I da CNBB, da Arquidiocese de São Paulo, da Região Episcopal Belém (SP) e da Paróquia de Vila Alpina (SP)", o rol dos agradecimentos vale ser recuperado, pois é representativo da rede que se formava entre religiosos, intelectuais e militantes sindicais, especialmente em São Paulo:

- Dom Paulo Evaristo Arns, pela sua fé na importância da juventude e pelas suas sugestões.

- Nelson de Moura, que contribui com as ilustrações

- Pe. Hilário Dick S.J., Assessor Nacional da P. J. ${ }^{352}$

- Pe. José Lino Hack (S.D.B. ${ }^{353}$, do Instituto Pastoral de Juventude de Porto Alegre.

- Luiz Maria Goicoechea, Assessor Latino-Americano do Movimento Internacional de Estudantes Católicos (MIEC).

- Plínio de Arruda Sampaio, advogado, professor da PUC São Paulo. Consultor da ONU, ex-deputado federal e ex-dirigente nacional da JUC.

- Delmar Mattos, da oposição sindical (metalúrgica) de São Paulo.

- Pe. Geraldo Lima, assistente nacional da JOC.

- Domingos Corcioni, Assessor da P.J. CNBB Nordeste II $^{354}$.

A lista se estende, citando teólogos, padres, irmãs, agentes de pastoral e jovens. Mas, entre os nomes citados acima, é possível inferir alguns pontos. Primeiro, a coordenação da atividade pastoral entre diversas instituições e instâncias da Igreja, das mais locais às nacionais e mesmo, no caso do movimento dos estudantes católicos, internacionais. Segundo, o exemplo de Plínio de Arruda Sampaio relembra que muitos

\footnotetext{
352 Pastoral da Juventude.

${ }^{353}$ Salesianos Dom Bosco.

${ }^{354}$ BORAN C.S.sp., Pe. Jorge. Juventude: O Grande Desafio. São Paulo, Edições Paulinas, 1982. (Igreja Dinâmica), p. 5.
} 
quadros que tiveram um papel destacado na redemocratização e na Constituinte não se aproximaram da Igreja, mas foram formados por ela. Aqueles que eram jovens militantes de organizações como a JUC entre as décadas de 1950 e 1960 já eram, nos anos 1980, líderes estabelecidos. Considere-se, ainda, que essa formação seguia em curso nas décadas de 1970 e 1980, e muitas das novas lideranças dos movimentos populares e mesmo sindicais iniciavam sua vida pública nas comunidades eclesiais de base ${ }^{355}$. O livro em questão, Juventude: O Grande Desafio, apresentava-se como uma "metodologia" para a pastoral da juventude, da formação teórica à organização dos movimentos em diversos níveis, como se vê na ilustração presente no livro e reproduzida abaixo.

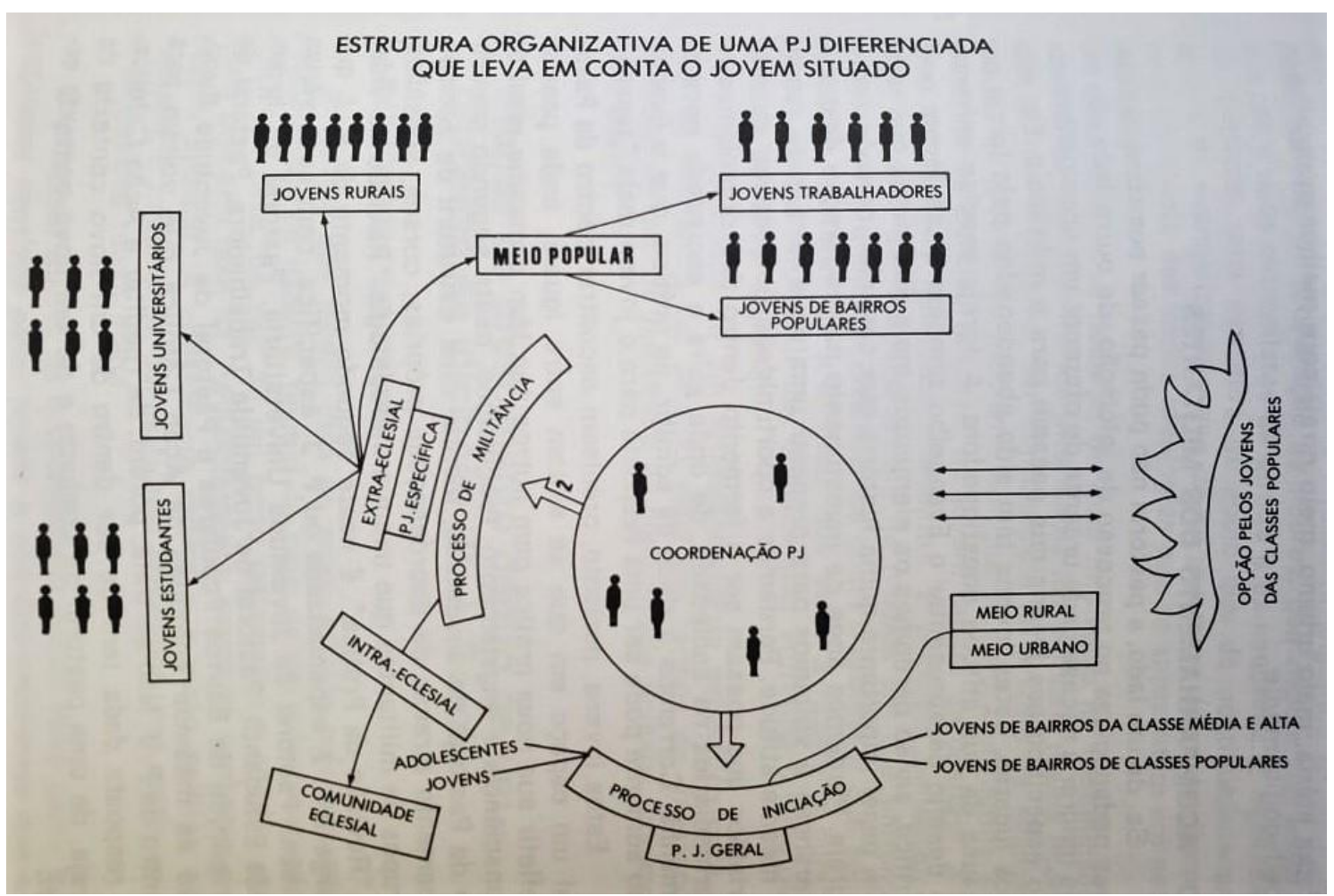

Figura 14: BORAN C.S.sp., Pe. Jorge. Juventude: O Grande Desafio. São Paulo, Edições Paulinas, 1982. (Igreja Dinâmica), p. 223. As ilustrações do livro são de Nelson de Moura.

\footnotetext{
355 O caso mais conhecido foi o do operário metalúrgico Santo Dias. Depois, muitos antigos membros das
} CEBs se tornariam quadros de destaque do Partido dos Trabalhadores. 
Trata-se de uma estrutura bem definida: todas as ações partem da coordenação. Além disso, reconhece a necessidade de uma pastoral diferenciada não apenas entre campo e cidade, mas também entre os jovens do "meio popular", incluindo os trabalhadores, e das classes médias e altas, como os universitários - condição ainda considerada, de forma implícita, praticamente inalcançável aos filhos das classes operárias e, que dirá, camponesas. A questão dos "meios específicos" ou das "pastorais da juventude específicas" herda muito das divisões das seções de juventude da Ação Católica. A novidade de Juventude: O Grande Desafio está na relação que esses grupos de jovens podem estabelecer com outros coletivos. Trata-se da "descoberta da ação extraeclesial”, em que "o jovem descobre sua vocação específica de leigo, de ser 'sal' e 'luz' no coração da sociedade moderna”, vocação que deveria, entretanto, ser iluminada pela fé, ainda que em organismos autônomos ${ }^{356}$ à Igreja ${ }^{357}$. Estes organismos o autor denomina como "corpos sociais intermediários", que para ele se encadeariam, em linhas gerais, dessa maneira:

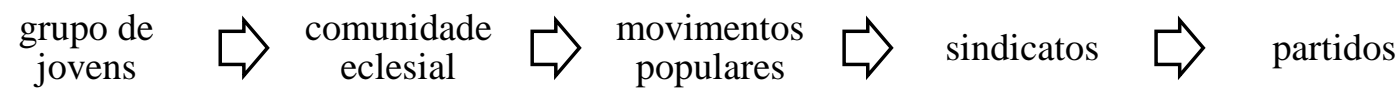

Nessa concepção, a Igreja (segundo a nova definição do Concílio Vaticano II, de Igreja como "Povo de Deus", isto é, uma comunidade de fiéis antes que uma instituição ${ }^{358}$ ) se vê como parte da própria estrutura social. A tomada de consciência do cristão, leigo, para o mundo ocorreria, em um primeiro momento, no próprio grupo de juventude católica ou na comunidade eclesial de base (ambos no singular). E, idealmente, a organização e a consciência levariam a uma extrapolação do associativismo local (que

\footnotetext{
${ }^{356}$ Como os sindicatos, que, em diversas passagens, são referidos como "oposição sindical". Isto é, os sindicatos "pelegos", subservientes aos patrões e ao regime, não são vistos como organismos autônomos; apenas o sindicalismo "autêntico", que se fortalecia no período.

${ }^{357}$ BORAN C.S.sp., Pe. Jorge. Juventude: O Grande Desafio, op. cit., p. 230.

${ }^{358}$ A definição foi instituída em PAULO VI. Constituição Dogmática Lumen Gentium Sobre a Igreja. Roma, 21 de novembro de 1964.
} 
não deve, entretanto, ser abandonado por quem se integra a outros movimentos, pois este deve manter suas relações com a comunidade) até a forma máxima de organização política, os partidos (assim como "movimentos populares" e "sindicatos", no plural, isto é, de um único grupo de jovens ou comunidade eclesial à pluralidade de movimentos, sindicatos e partidos).

Tratava-se, portanto, não apenas de engajamento nas atividades paroquiais, mas de um projeto de sociedade. Se a Igreja, como instituição, não pudesse estar presente em todas as esferas, ela formaria as pessoas que nelas atuariam, como leigos, porém cristãos. Como vimos buscando demonstrar, a própria estruturação da CNBB objetivava uma inserção maior na vida pública nacional. E um de seus meios principais era a comunicação, levada a cabo pelas editoras católicas. A coleção Igreja Dinâmica, com esses e outros livros para formar a pastoral da juventude - e os pastores, isto é, os "agentes de pastoral", por exemplo, em 1994, Jorge Boran publicaria pela mesma série o volume Curso de Treinamento para Lideranca (CTL) - fazia parte desse projeto mais amplo.

Outra coleção, Pastoral e Comunidade, tinha os mesmos objetivos de organizar as pastorais e comunidades eclesiais de base. Essa coleção se inicia em 1976 com livros escritos conjuntamente por José Marins, Carolee Chanona e Teolide Maria Trevisan. Mas, as capas trazem apenas a inscrição "José Marins e Equipe”, e os nomes das outras autoras, freiras, constam apenas no interior do livro. A partir de 1980, a coleção passa a publicar também livros de outros autores relativos ao mesmo tema (cf. Tabela 5).

Semelhantes, também, eram as perspectivas expressas em um livro de 1987, CEBs: Poder, Nova Sociedade, de Adelina Baldissera, publicado na coleção Fermento na Massa, editada pelos paulinos. Metáfora bíblica recorrente, o fermento na massa representa o papel dos cristãos no mundo: não são o corpo da massa (a farinha), mas modificam seu caráter, transformando-a em pão. Nome adequado a uma coleção de estudos produzidos, 
em sua maioria, na universidade, a respeito da teologia da libertação e das comunidades eclesiais de base (a exceção ao elemento religioso é o volume de Carmela Panini, Reforma Agrária Dentro e Fora da Lei: 500 Anos de História Inacabada). Pela coleção, infere-se que essas reflexões teológicas e sociológicas são tidas pelos editores paulinos como o fermento para a Igreja em transformação.

Os primeiros volumes da coleção Fermento na Massa, Horizonte de Esperança: Teologia da Libertação, de Juvenal Arduini ${ }^{359}$, e Igreja para a Libertação: Retrato Pastoral da Igreja no Brasil, de David Regan ${ }^{360}$, foram lançados em 1986. No ano seguinte, sai CEBs: Poder, Nova Sociedade, de Adelina Baldissera. A quarta capa, abaixo de um comentário da obra assinado pelo bispo de Pelotas, RS, Jayme Chemello, traz uma interessante biografia da autora: formada em serviço social, era atuante em diversas instâncias das equipes pastorais da Igreja ${ }^{361}$.

O livro em questão, fruto de sua dissertação de mestrado, discute algumas relações de poder dentro das CEBs e destas com a sociedade mais ampla. A autora entende, por exemplo, que as comunidades eclesiais seriam a semente de uma nova sociedade sem exploração e dominação, formando uma "nova hegemonia" (Gramsci é uma das principais referências teóricas do livro), um novo "bloco social de forças"; como no livro de Jorge Boran, das CEBs brotaria a consciência dos antagonismos de classe, que levaria à organização dos movimentos populares, sindicatos e partidos. Baldissera, utilizando metáforas do mundo do trabalho, assim resume esse processo:

\footnotetext{
${ }^{359}$ Padre e antropólogo, foi professor de diversas universidades de Uberaba, MG.

360 Religioso pertencente à Congregação do Espírito Santo, cujos membros são conhecidos como espiritanos.

361 "Nasceu em Garibaldi, RS. Fez curso de mestrado em Serviço Social. Como assistente social seu campo de trabalho é vasto: colônias de pescadores, zona rural, periferia da cidade. Outras atividades, atualmente, na diocese e no município de Pelotas: coordenação do Programa de Desenvolvimento da Comunidade, do projeto "Saúde e Comunidade", do setor Pastoral da Juventude e do curso de Serviço social. Membro da Equipe de Assessoria das CEBs, tendo participado do VI Encontro Intereclesial das CEBs em Trindade" BALDISSERA, Adelina. CEBs: Poder, Nova Sociedade. São Paulo, Edições Paulinas, 1987. (Fermento na Massa).
} 
O facão são as CEBs que iniciam o trabalho desmatando o mato; a foice são os movimentos populares que vão abrindo caminho e desenvolvendo a consciência política; o machado é o partido para derrubar as árvores grandes ${ }^{362}$.

A autora se ocupa, também, de algumas contradições presentes nas comunidades, um tema recorrente nos estudos do período. Para compreendê-las, é preciso considerar o papel que religiosos e leigos intelectualizados tiveram nas comunidades eclesiais de base, na figura do agente de pastoral. Trata-se realmente de um agente, isto é, de uma pessoa enviada pela coordenação pastoral da diocese para organizar ou mesmo criar uma CEB. Jomar Ricardo da Silva estudou comunidades do interior da Paraíba e explica como elas foram formadas, a partir de 1987,

[...] quando uma equipe de agentes de pastoral chegou à localidade com um projeto diocesano. Havia nessa equipe um padre, nomeado para a região no mesmo ano, dois estagiários e uma religiosa [...]

Os agentes de pastoral iniciam a atuação fazendo visitas às casas dos moradores da cidade e da zona rural, para conhecerem as pessoas e convidá-las às reuniões em que compareceriam os primeiros animadores das comunidades ${ }^{363}$.

Enquanto o agente de pastoral era externo, o animador era um membro da própria comunidade, porém, com menor poder de decisão, fato que gerava tensões: Jomar da Silva narra como os agentes - e, às vezes, um pequeno número de animadores mais próximos a eles - vão sendo considerados pelos demais membros uma "elitezinha"364.

Adelina Baldissera dedica um capítulo a compreender qual seria o verdadeiro papel do agente de pastoral, que deveria ser um "intelectual orgânico"365 das CEBs, e não

\footnotetext{
362 Idem, pp. 215-216.

363 SILVA, Jomar Ricardo da. "O Rendilhado de Poderes e Tensões. As Inter-relações de Animadores e Agentes de Pastoral nas CEBs”. Revista Eclesiástica Brasileira, n. 62, vol. 247, 2002, p. 578.

${ }^{364}$ Idem, pp. 595-600.

${ }^{365} \mathrm{O}$ que, sob o ponto de vista gramsciano (que é, também, o de Baldissera), não nos parece plausível, por várias razões. Primeiro, porque o agente de pastoral não exerce a função de intelectual dentro da Igreja. Função que seria exercida, antes, por quadros como os autores dos livros estudados, ou mesmo pelos próprios editores, que trabalhavam com a formação desses agentes por outros meios além dos livros, como vimos no caso do Sepac no capítulo 3. Esses autores, editores e professores, fossem religiosos como os
} 
deveria cair em atitudes "manipuladoras" ou "paternalistas". A autora tem consciência de que a figura do agente era problemática; mas, como vimos, ela própria uma coordenadora das equipes de pastoral, falando em nome do "povo" considera o agente externo indispensável:

O povo trabalhador assimilou a figura do patrão, do chefe, do "líder", que dirige e controla as suas ações. Diante do agente de pastoral, seja ele de classe média seja de classe trabalhadora, a tendência encontrada é a mesma: solicitar a sua última palavra, a sua orientação. Assim, o agente corre o risco de assumir a direção da caminhada. O povo, entretanto, reconhece que ainda precisa, no atual momento, do agente ${ }^{366}$.

Essa contradição poderia se estender à própria estrutura de coordenação dessas comunidades e, no que tange mais diretamente nosso objeto, à própria produção de impressos para pautar as discussões das CEBs, produção que contribuía para manter as comunidades sob o domínio da Igreja Católica.

Para a editora, o trabalho exercido pelo agente de pastoral também é importante porque expande o público cuja compra de determinados livros é mais assegurada que a dos leigos, isto é, o público religioso. João Adolfo Hansen comenta como a compra de determinados livros na época de Gutenberg era garantida pelo grande número de sacerdotes e membros das ordens religiosas ${ }^{367}$. Proporcionalmente, esse número era muito menor no Brasil do século XX, mas ainda se mantinha como uma garantia de venda de obras específicas, como missais. O agente de pastoral, que podia ser um leigo, aumenta assim o potencial de venda dos materiais da editora, sobretudo, é claro, aqueles destinados

paulinos ou leigos como Baldissera, estariam muito mais próximos da figura do "intelectual tradicional" que do "orgânico", isto é, antes ligados à Igreja que a uma classe. Segundo, mesmo se considerarmos que o agente de pastoral exerce a função de intelectual nas CEBs, ele não poderia ser orgânico, visto que era quase sempre externo às comunidades (periféricas ou rurais) e provinha, na maioria das vezes, das classes médias universitárias. Cf. GRAMSCI, Antonio. Os Intelectuais e a Organização da Cultura. 4. ed. Trad. Carlos Nelson Coutinho. Rio de Janeiro, Civilização Brasileira, 1982.

${ }^{366}$ BALDISSERA, Adelina. CEBs: Poder, Nova Sociedade, op. cit., p. 124. Grifo meu.

${ }^{367}$ Cf. HANSEN, João Adolfo. O Que É um Livro? Cotia/São Paulo, Ateliê/Edições Sesc, 2019, p. 32. 
ao uso da (ou ao estudo sobre as) comunidades eclesiais de base, já que seu líder poderia comprar múltiplos exemplares para uso do grupo.

É preciso lembrar, também, que as CEBs eram formadas principalmente por mulheres, incluindo as lideranças. Os agentes de pastoral, quando religiosos, eram sobretudo freiras; quando leigos, sua maioria também era de mulheres. A figura da mulher periférica, que cuida da economia doméstica, leva os filhos ao médico, utiliza o transporte público e estabelece uma convivência maior com o bairro do que o homem operário que passa o dia na fábrica, dava o tom às prioridades da comunidade. Essa intensa participação feminina não se restringia às comunidades eclesiais, pois ocorria em outras associações, religiosas ou não, desde as de bairro até outras maiores e mais organizadas, como o Movimento do Custo de Vida. Mas, no ambiente paroquial, ela era dominante. Isso incentivou a participação de mulheres excluídas da vida pública, fosse por sua condição social, como as donas de casa, fosse pela própria limitação de mobilização imposta pela ditadura, como no caso de militantes de classe média - ligadas, por exemplo, à universidade - que também passam a frequentar esses movimentos. Segundo Maria Lygia Quartim de Moraes,

[...] a ala esquerda da Igreja Católica [...] cresceu no meio popular por intermédio da criação de clubes de mães e outras formas organizativas, também utilizadas no processo de reorganização das esquerdas. A presença da Igreja nas periferias mais politizadas abriu um importante espaço de atuação para as feministas de São Paulo, que atuavam nas dioceses mais progressistas, como no município de Osasco e na Freguesia do Ó ${ }^{368}$.

Porém, os tabus católicos do divórcio e do aborto sempre permaneceram como pontos de discórdia, o que contribuía para que a aproximação entre a Igreja e militantes

\footnotetext{
368 MORAES, Maria Lygia Quartim de. “O Encontro Marxismo-Feminismo no Brasil”. In: RIDENTI, Marcelo \& REIS, Daniel Aarão (org.). História do Marxismo no Brasil, vol. 6: Partidos e Movimentos Após os Anos 1960. Campinas, Editora da Unicamp, 2007, pp. 346-347.
} 
oriundos da esquerda e de movimentos feministas estivesse em permanente tensão. As questões sexuais e reprodutivas se mantiveram com um tabu mesmo nos círculos progressistas da Igreja; sobre isso, os paulinos publicaram a partir da década de 1980 a coleção Planejamento Familiar: todos livros de instruções sobre o "método Billings", um método para identificar o período de ovulação, não sendo divulgadas outras formas de contracepção não permitidas pela Igreja. Nos preparativos para a Campanha da Fraternidade de 1990, que tinha como tema "Fraternidade e a Mulher", é publicada uma coletânea chamada Mulher: da Escravidão à Libertação. Dos sete capítulos, dois eram dedicados a criticar o "aborto espontâneo" e a pílula do dia seguinte ${ }^{369}$.

A participação de outros grupos, mais ou menos externos à Igreja, levanta mais uma questão. Como vem sendo reiterado, todo o catálogo das Edições Paulinas era dedicado ao catolicismo, e mesmo livros sobre temáticas distintas, como saúde ou direitos sociais, possuíam elementos religiosos. Sob essa perspectiva, é possível considerar algumas das publicações das Edições Paulinas destinadas às CEBs de forma inversa que a habitual: não se trata apenas de propor uma reflexão política em um ambiente religioso, mas, também, de manter o elemento religioso na discussão política, isto é, de conservar as CEBs, em sua maioria já muito politizadas, sob o catolicismo. Ainda mais se considerarmos que, ao longos dos anos 1980, conforme muitos movimentos sociais tomavam forma e se organizavam, publicações como "cartilhas" e "cadernos" se multiplicavam, e atingiram o auge de produção no período da campanha pela Constituinte ${ }^{370}$.

\footnotetext{
369 D’ARNS, Hugues (org.). Mulher: da Escravidão à Libertação. São Paulo, Edições Paulinas, 1989. (Pastoral e Comunidade).

370 Ver, por exemplo, NEVES, Ozias Paese. Imaginários e Utopias na Passagem entre Ditadura e Redemocratização: O Momento Constituinte em Cartilhas (1985-1988). Tese de Doutorado em História, Universidade Federal do Paraná, 2017.
} 
Essa foi, até certo ponto, a perspectiva de Eder Sader. Ao considerar "o cristianismo das comunidades de base" uma das três "matrizes discursivas" dos movimentos sociais da época, ao lado do "marxismo de uma esquerda dispersa" e do “novo sindicalismo", ele afirma que

Usando as categorias de um discurso religioso - a verdade e a justiça, a Palavra de Deus e o Povo de Deus, o Pecado e a Libertação -, os discursos pastorais aplicaram-nas a temas mais profanos, da experiência cotidiana de seus membros. Constituíram assim sujeitos imbuídos de fé numa luta terrena pela justiça social ${ }^{371}$.

Como apresentamos acima, em livros como os de Adelina Baldissera e Jorge Boran a questão do partido já se colocava como central. Desde 1978, mas principalmente após 1979, com a Reforma Partidária, antes mesmo da criação formal do Partido dos Trabalhadores, a ideia de sua existência começava a aglutinar sindicalistas, intelectuais e militantes católicos progressistas. Muitos de seus membros de maior destaque seriam exlíderes comunitários católicos. Porém, nas publicações católicas ligadas diretamente à Igreja - por exemplo, das Edições Paulinas - evita-se usar o nome do partido ${ }^{372}$. Quando a questão se torna eleitoral, em 1982, mesmo alguns membros da hierarquia eclesiástica progressista estabelecem diretrizes às CEBs e paróquias (por exemplo, não ceder o salão

\footnotetext{
371 SADER, Eder. Quando Novos Personagens Entraram em Cena: Experiências, Falas e Lutas dos Trabalhadores da Grande São Paulo 1970-1980. Rio de Janeiro, Paz e Terra, 1988, p. 167.

${ }^{372}$ No catálogo da editora estudada, foi encontrada uma única exceção, que menciona explicitamente o PT e prega o voto nesse partido específico. Trata-se de um "caderno de educação popular" (cf. nota acima) de autoria do Cepis - Centro de Educação Popular do Instituto Sedes Sapientiae, denominado O que É Política, Partido e a Atual Reformulação Partidária, publicado em novembro de 1981 pelas Edições Paulinas. O livreto segue o esquema dos demais "cadernos" da editora, bastante ilustrado e com linguagem simplificada. Nele, são expostos o PDS, PP, PMDB, PTB, PDT e PT, demonstrando as vantagens deste último, "por tudo o que representa de avanço, de novo e de esperança para os trabalhadores". No Sedes Sapientiae, ligado a membros da PUC-SP, ocorreria o II Encontro Nacional do PT alguns meses depois, em março de 1982 (cf. SECCO, Lincoln. História do PT. 5. ed. Cotia, Ateliê, 2018, p. 75). No caderno, há também a informação: "Esse texto também vai ser distribuído pelo CPV - Centro Pastoral Vergueiro". O CPV, que funcionava como um centro cultural e contava com livraria, biblioteca e equipe editorial, foi um ponto importante de articulação entre movimentos sociais, a esquerda e a Igreja Católica (cf. SALLES, Paula Ribeiro. Documentação e Comunicação Popular: A Experiência do CPV - Centro de Pastoral Vergueiro (São Paulo/SP, 1973-1989). Dissertação de Mestrado em História Social, Pontifícia Universidade Católica de São Paulo, 2013).
} 
paroquial para eventos de campanha) para tentar desvincular os movimentos católicos da campanha "partidária", como foi o caso de Paulo Evaristo Arns e Cláudio Hummes ${ }^{373}$.

A antropóloga Carmen Macedo realizou, a partir de 1982, uma pesquisa em uma comunidade eclesial de base de um bairro da região da Brasilândia, Zona Norte de São Paulo. Segundo ela, a campanha eleitoral de 1982 fora o auge da mobilização comunitária até então ${ }^{374}$. Sobre ela, um dos líderes, seminarista, afirmou:

Nossa opção eleitoral no bairro foi mais para o PT. Minha orientação: "na hora de votar, vamos lembrar de quem sempre esteve aqui com a gente". Tinha uns slides que ajudavam muito. Chamava "Fé e Política". Falava da vida política do país, dos partidos que tinha antes de 1964; [...] até chegar no ponto onde a estrada se divide e os caminhos são os diferentes partidos. Foi muito criticado na época, pela imprensa, mas lá [na comunidade] eles gostaram muito ${ }^{375}$.

$\mathrm{Na}$ fala, embora não se trate especificamente de um impresso, é possível perceber como esses materiais contribuíam para pautar as discussões. Na campanha municipal de São Paulo em 1988, a mobilização das CEBs foi relevante para a eleição de Luiza Erundina, que já havia trabalhado com as comunidades, pelo PT. Ao longo da década seguinte, entretanto, conforme a política se institucionalizava, as CEBs tiveram seu papel enfraquecido. Trata-se de uma via de mão dupla. Por um lado, afirma Cláudio Gonçalves Couto que a própria forma de "fazer política" das CEBs era intrinsecamente distinta da política representativa:

As CEBs constituíram-se, durante a ditadura, num foco de organização da população no sentido da reivindicação de direitos. Assim, além do caráter participativo e externo ao Estado assumido pelos movimentos reivindicatórios, era-lhe somado um ethos comunitário, característico do engajamento católico. Os participantes

\footnotetext{
373 MACHADO, Adriano Henriques. Os Católicos optaram? Os "Setores Católicos" e o Partido dos Trabalhadores (PT) na Grande São Paulo (1978-1982). Dissertação de Mestrado em História, PUC-SP, 2010, pp. 124-148.

${ }^{374}$ MACEDO, Carmen Cinira de Andrade. Tempo de Gênesis: O Povo das Comunidades Eclesiais de Base. São Paulo, Brasiliense, 1986, p. 105.

375 Idem, p. 261.
} 
das CEBs e dos movimentos animados pela Igreja se reconheciam como agentes políticos a partir de seu próprio reconhecimento como membros de uma comunidade de iguais, portadores de direitos, participantes nessa comunidade e autônomos frente aos governantes - e, portanto, ao Estado - , aos partidos políticos e a outras organizações ${ }^{376}$.

Ao mesmo tempo, Lincoln Secco afirma que as próprias transformações na Igreja Católica - a divisão da Arquidiocese de São Paulo em 1989, o crescimento da Renovação Carismática e das igrejas evangélicas - contribuíram para "o declínio da militância” do PT na década de $1990^{377}$.

Ambas as perspectivas não são excludentes. É preciso ter em mente que, ao mesmo tempo, as comunidades eclesiais de base eram movimentos "de base", muitas vezes geridas pelos próprios participantes e atreladas a sua vida cotidiana, mas, também, eram espaços de poder em disputa, na qual se digladiavam diversos movimentos sociais, partidos e a própria Igreja, com sua infinidade de contradições, correntes e divergências. A grande quantidade de publicações sobre as CEBs e para as CEBs, e não apenas pelas Edições Paulinas, mas até mesmo por editoras laicas, demonstra como havia um anseio de pautar as discussões ali realizadas; mas cabia aos membros e, principalmente, aos agentes de pastoral e ao pároco local a decisão de utilizar este ou aquele material, ou até mesmo de produzir o seu próprio. No período da abertura, havia intelectuais externos à Igreja também muito otimistas com o potencial democrático das CEBs. Para eles, esse potencial se encontrava, inclusive, no fato de algumas comunidades produzirem seus próprios materiais de comunicação:

Aqueles setores eclesiásticos comprometidos com os pobres encontram na experiência das CEBs o lugar deste compromisso, que redunda no exercício e no aprendizado de práticas embrionárias de participação democrática. Essas práticas incluem a discussão em grupo, o treino da fala, o domínio de auditórios maiores (por ocasião dos

${ }^{376}$ COUTO, Cláudio Gonçalves. "Mudança e Crise: O PT no Governo em São Paulo". Lua Nova, n. 33, ago. 1994.

${ }^{377}$ SECCO, Lincoln. História do PT, op. cit., pp. 178-180. 
encontros em nível arquidiocesano, por exemplo), o exercício da escrita, o manuseio de mimeógrafos e outros modestos veículos de comunicação, a prática reiterada do voto para toda e qualquer decisão $0^{378}$.

Mas, é preciso considerar a grande quantidade de publicações produzidas por editoras como as Edições Paulinas e, também, por órgãos eclesiásticos (arquidioceses, comissões pastorais etc.), destinadas às comunidades ou a seus coordenadores diocesanos e agentes de pastorais. Se, por um lado, as CEBs não eram totalmente independentes nem espontâneas, por outro, mantinham sua relativa autonomia, em grau variável de comunidade para comunidade. Por isso, tanto as questões internas às comunidades quanto aquelas relativas à conjuntura dos altos escalões eclesiásticos e políticos são elementos importantes para compreender sua ascensão e queda.

Até aqui, apresentamos diversas publicações relativas à teologia da libertação e às comunidades eclesiais de base. Mas, entre essa multiplicidade de livros, havia um protagonista, do qual trataremos na seção seguinte.

\footnotetext{
${ }^{378}$ CAMARGO, Candido Procopio Ferreira de; SOUZA, Beatriz Muniz de \& PIERUCCI, Antônio Flávio de Oliveira. "Comunidades Eclesiais de Base". In: BRANT, Vinícius Caldeira \& SINGER, Paul (org.). São Paulo: O Povo em Movimento. Petrópolis, Vozes, 1980, p. 77.
} 
Tabela 5. Coleções sobre Teologia da Libertação e Comunidades Eclesiais de Base

Publicadas pelas Edições Paulinas

\begin{tabular}{|c|c|c|}
\hline Ano & Título & Autor \\
\hline \multicolumn{3}{|c|}{ Libertação e Teologia ${ }^{379}$} \\
\hline 1978 & $\begin{array}{c}\text { Teologia da Libertação: Ensaio de } \\
\text { Síntese }\end{array}$ & Segundo Galilea \\
\hline 1980 & A Igreja das Bem-Aventuranças & Segundo Galilea \\
\hline 1980 & Pobres e Libertação em Puebla & Gustavo Gutiérrez \\
\hline 1980 & Os Teólogos da Libertação & Battista Mondin \\
\hline 1981 & $\begin{array}{c}\text { A Bíblia dos Oprimidos: A Opressão na } \\
\text { Teologia Bíblica }\end{array}$ & Elsa Tamez \\
\hline 1981 & $\begin{array}{l}\text { Evangelho e Libertação na América } \\
\text { Latina: A Teologia Pastoral de Puebla }\end{array}$ & Ronaldo Muñoz \\
\hline 1981 & $\begin{array}{l}\text { A Fé em História e Sociedade: Estudos } \\
\text { para uma Teologia Fundamental Prática }\end{array}$ & Johann Baptist Metz \\
\hline 1982 & $\begin{array}{c}\text { O Evangelho Beligerante: Introdução } \\
\text { Crítica às Teologias Políticas }\end{array}$ & Alfredo Fierro \\
\hline 1982 & $\begin{array}{c}\text { A Luta dos Deuses: Os Ídolos da } \\
\text { Opressão e a Busca do Deus Libertador }\end{array}$ & Sérgio Torres (org.) ${ }^{380}$ \\
\hline 1982 & Os Desafios de Puebla & Carlos Eroles \\
\hline 1982 & $\begin{array}{c}\text { A Igreja que Surge da Base: Eclesiologia } \\
\text { das Comunidades Cristãs de Base }\end{array}$ & Sérgio Torres (org.) $)^{381}$ \\
\hline 1982 & Exodo: Uma Hermenêutica da Liberdade & Severino Croatto \\
\hline 1982 & $\begin{array}{c}\text { O Futuro de Puebla: Repercussão Social } \\
\text { e Eclesial }\end{array}$ & Hernán Alessandri \\
\hline 1982 & Variações sobre a Vida e a Morte & Rubem Alves \\
\hline 1982 & A Hora de Maria, a Hora da Mulher & Maria Teresa Porcile Santiso \\
\hline 1982 & O Evangelho Emergente & $\begin{array}{l}\text { Sérgio Torres; Virginia } \\
\text { Fabella }\end{array}$ \\
\hline
\end{tabular}

\footnotetext{
379 Até 1981, Libertação Teológica.

${ }^{380}$ Textos de Pablo Richard; Severino Croatto; Frei Betto; Victorio Araya; Jorge Pixley; Jon Sobrino; Javier Jiménez Limón; Franz Hinkelammert; Joan Casañas; Hugo Assmann.

381 Textos do IV Congresso Internacional Ecumênico de Teologia, São Paulo, 1980.
} 


\begin{tabular}{|c|c|c|}
\hline 1982 & Dogmatismo e Tolerância & Rubem Alves \\
\hline 1982 & $\begin{array}{c}\text { Estamos Salvos: O Cristão diante das } \\
\text { Ideologias }\end{array}$ & D. Valfredo Tepe \\
\hline 1982 & $\begin{array}{c}\text { A Igreja Latino-Americana entre o } \\
\text { Temor e a Esperança: Apontamentos } \\
\text { Teológicos para a Década de } 80\end{array}$ & Pablo Richard \\
\hline 1984 & $\begin{array}{l}\text { Para Além de Uma Religião Burguesa: } \\
\text { Sobre o Futuro do Cristianismo }\end{array}$ & Johann Baptist Metz \\
\hline 1985 & O Deus dos Oprimidos & James H. Cone \\
\hline 1985 & $\begin{array}{c}\text { Luta pela Vida e Evangelização: A } \\
\text { Tradição Metodista na Teologia Latino- } \\
\text { Americana }\end{array}$ & José Míguez Bonino \\
\hline 1986 & $\begin{array}{c}\text { Libertação: Análise da "Instrução sobre } \\
\text { a Liberdade Cristã e a Libertação" }\end{array}$ & Benedito Beni dos Santos \\
\hline 1986 & Inculturação e Libertação & $\begin{array}{c}\text { Semana de Estudos } \\
\text { Teológicos Cimi-CNBB } \\
\text { 382 }\end{array}$ \\
\hline 1987 & Jesus Antes do Cristianismo ${ }^{383}$ & Albert Nolan \\
\hline 1987 & $\begin{array}{c}\text { Teologia da Libertação: Uma } \\
\text { Advertência à Igreja }\end{array}$ & Juan Luis Segundo \\
\hline 1987 & Raízes da Teologia Latino-Americana & Pablo Richard (org.) \\
\hline 1988 & $\begin{array}{c}\text { A Fé como Ação na História: } \\
\text { Hermenêutica do Novo Testamento no } \\
\text { Contexto da América Latina } \\
\text { C84 }\end{array}$ & Ely Éser Barreto César \\
\hline 1988 & $\begin{array}{c}\text { Metodologia para Refletir a Partir do } \\
\text { Povo: E. Dussel e o Discurso Teológico } \\
\text { Norte-Americano }\end{array}$ & Roberto S. Goizueta \\
\hline \multicolumn{3}{|c|}{ Tempo de Libertação } \\
\hline 1982 & Por Que a Igreja Critica os Ricos? & $\begin{array}{c}\text { Juan Leuridan; Guilhermo } \\
\text { Múgica }\end{array}$ \\
\hline 1983 & $\begin{array}{c}\text { O Caminho da Espiritualidade: Visão } \\
\text { Atual da Renovação Cristã }\end{array}$ & Segundo Galilea \\
\hline
\end{tabular}

\footnotetext{
382 São Paulo, 1985.

383 Tradução do Grupo de Tradução São Domingos.

${ }^{384}$ Edição Conjunta Unimep, Universidade Metodista de Piracicaba.
} 


\begin{tabular}{|c|c|c|}
\hline 1983 & A Missão a Partir da América Latina & $\begin{array}{c}\text { José Comblin; Segundo } \\
\text { Galilea; J. Gorsky; José } \\
\text { Marins; G. Pape; G. Maiello }\end{array}$ \\
\hline 1983 & $\begin{array}{c}\text { Religião e Política na América Central: } \\
\text { Para uma Nova Interpretação da } \\
\text { Religiosidade Popular }\end{array}$ & $\begin{array}{c}\text { Pablo Richard; Diego } \\
\text { Irarrázaval }\end{array}$ \\
\hline 1983 & $\begin{array}{c}\text { A Graça e o Poder: As Comunidades } \\
\text { Eclesiais de Base no Brasil }\end{array}$ & Domingos Barbé \\
\hline 1984 & O Suspiro dos Oprimidos & Rubem Alves \\
\hline 1985 & $\begin{array}{c}\text { Bem-Aventurados os Que Têm Fome de } \\
\text { Justiça: A Vida da Igreja na América } \\
\text { Central }\end{array}$ & Johannes Meier \\
\hline 1986 & $\begin{array}{c}\text { Francisco Jentel: Defensor do Povo do } \\
\text { Araguaia }\end{array}$ & $\begin{array}{c}\text { Alain Dutertre; D. Pedro } \\
\text { Cadaldáliga ; D. Tomás } \\
\text { Balduíno }\end{array}$ \\
\hline 1988 & A Rebelião do Deus Domesticado & Renold J. Blank \\
\hline 1993 & $\begin{array}{c}\text { Seguir Jesus Hoje: Da Modernidade à } \\
\text { Solidariedade }\end{array}$ & Victor Codina \\
\hline \multicolumn{3}{|c|}{ Fermento na Massa } \\
\hline 1986 & $\begin{array}{c}\text { Horizonte de Esperança: Teologia da } \\
\text { Libertação }\end{array}$ & Juvenal Arduini \\
\hline 1986 & $\begin{array}{c}\text { Igreja para a Libertação: Retrato } \\
\text { Pastoral da Igreja no Brasil }\end{array}$ & David Regan \\
\hline 1986 & $\begin{array}{c}\text { Comunicação Popular e Alternativa no } \\
\text { Brasil }\end{array}$ & $\begin{array}{l}\text { Carlos Eduardo Lins da } \\
\text { Silva; Regina Festa }\end{array}$ \\
\hline 1986 & $\begin{array}{l}\text { A Lógica do Amor: Pensamento } \\
\text { Teológico de Carlos Mesters }\end{array}$ & Tereza Maria P. Cavalcanti \\
\hline 1987 & CEBs: Poder, Nova Sociedade & Adelina Baldissera \\
\hline 1989 & Destinação Antropológica & Juvenal Arduini \\
\hline 1989 & $\begin{array}{c}\text { A Igreja Voltada para o Homem: } \\
\text { Eclesiologia do Povo de Deus no Brasil }\end{array}$ & Joaquim G. Piepke \\
\hline 1990 & $\begin{array}{c}\text { Reforma Agrária Dentro e Fora da Lei: } \\
500 \text { Anos de História Inacabada }\end{array}$ & Carmela Panini \\
\hline
\end{tabular}




\begin{tabular}{|c|c|c|}
\hline \multicolumn{3}{|c|}{ Estudos \& Debates Latino-Americanos } \\
\hline 1982 & $\begin{array}{c}\text { Política e Igreja. O Partido Católico no } \\
\text { Brasil: Mito ou Realidade? }\end{array}$ & Oscar Figueiredo Lustosa, op \\
\hline 1982 & $\begin{array}{c}\text { Morte das Cristandades e Nascimento da } \\
\text { Igreja: Análise Histórica e Interpretação } \\
\text { Teológica da Igreja na América Latina }\end{array}$ & Pablo Richard \\
\hline 1982 & $\begin{array}{c}\text { Das Reduções Latino-Americanas às } \\
\text { Lutas Indígenas Atuais }\end{array}$ & Eduardo Hoornaert (org.) ${ }^{385}$ \\
\hline 1983 & $\begin{array}{c}\text { A Vida Religiosa no Brasil: Enfoques } \\
\text { Históricos } \\
\text { H86 }\end{array}$ & Riolando Azzi \\
\hline 1984 & $\begin{array}{c}\text { Os Santos Nômades e o Deus } \\
\text { Estabelecido: Um Estudo sobre Religião } \\
\text { e Sociedade }\end{array}$ & Luiz Roberto Benedetti \\
\hline 1984 & $\begin{array}{l}\text { O Celeste Porvir: A Inserção do } \\
\text { Protestantismo no Brasil }\end{array}$ & Antonio Gouvêa Mendonça \\
\hline 1984 & $\begin{array}{c}\text { A Mulher Pobre na História da Igreja } \\
\text { Latino-Americana }\end{array}$ & $\begin{array}{l}\text { Maria Luiza Marcílio } \\
\text { (org.) }{ }^{387}\end{array}$ \\
\hline 1985 & $\begin{array}{c}\text { Caminhos de Libertação Latino- } \\
\text { Americana. Tomo I: Interpretação } \\
\text { Histórico-Teológica }\end{array}$ & Enrique Dussel \\
\hline 1985 & $\begin{array}{c}\text { Caminhos de Libertação Latino- } \\
\text { Americana. Tomo II: História, } \\
\text { Colonialismo e Libertação }\end{array}$ & Enrique Dussel \\
\hline 1985 & $\begin{array}{c}\text { Caminhos de Libertação Latino- } \\
\text { Americana. Tomo III: Interpretação } \\
\text { Ético-Teológica }\end{array}$ & Enrique Dussel \\
\hline 1985 & $\begin{array}{c}\text { Caminhos de Libertação Latino- } \\
\text { Americana. Tomo IV: Reflexões para uma } \\
\text { Teologia da Libertação }\end{array}$ & Enrique Dussel \\
\hline 1985 & $\begin{array}{c}\text { Religiosidade Popular na Teologia } \\
\text { Latino-Americana }\end{array}$ & Helcion Ribeiro \\
\hline
\end{tabular}

385 Textos do IX Simpósio Latino-Americano da Cehila, Manaus, 1981.

${ }^{386}$ Ed. conj. Cehila.

387 Textos do IX Simpósio Internacional da Cehila, San Antonio, Texas, 1983. 


\begin{tabular}{|c|c|c|}
\hline 1985 & $\begin{array}{c}\text { Memória do Sagrado: Estudos de } \\
\text { Religião e Ritual }\end{array}$ & Carlos Rodrigues Brandão \\
\hline 1985 & Voz do Padre Cícero e Outras Memórias & $\begin{array}{c}\text { Maria da Conceição Lopes } \\
\text { Campina }\end{array}$ \\
\hline 1985 & $\begin{array}{c}\text { O Pensamento Cristão Revolucionário } \\
\text { na América Latina e no Caribe (1960- } \\
\text { 1973): Implicações da Teologia da } \\
\text { Libertação para a Sociologia da Religião }\end{array}$ & Samuel Silva Gotay \\
\hline 1986 & $\begin{array}{c}\text { A Igreja e a Questão Agrária no } \\
\text { Nordeste: Subsídios Históricos }\end{array}$ & Severino Vicente da Silva \\
\hline 1986 & $\begin{array}{c}\text { Os Religiosos no Brasil: Enfoques } \\
\text { Históricos }\end{array}$ & $\begin{array}{c}\text { Riolando Azzi; José Oscar } \\
\text { Beozzo (org.) }\end{array}$ \\
\hline 1986 & $\begin{array}{c}\text { Igreja Católica no Brasil: Um Estudo de } \\
\text { Mentalidade Ideológica }\end{array}$ & José Carlos Sousa Araújo \\
\hline 1988 & $\begin{array}{c}\text { A Igreja e o Controle Social nos Sertões } \\
\text { Nordestinos }\end{array}$ & $\begin{array}{l}\text { Severino Vicente da Silva } \\
\text { (org.) }\end{array}$ \\
\hline 1989 & A Igreja e o Socialismo 389 & Raul Gomez Treto \\
\hline 1991 & $\begin{array}{l}\text { A Igreja Católica no Brasil-República: } \\
\text { Cem Anos de Compromisso (1889-1989) }\end{array}$ & Oscar de Figueiredo Lustosa \\
\hline 1992 & $\begin{array}{c}\text { A Igreja e o Menor na História Social } \\
\text { Brasileira }\end{array}$ & Riolando Azzi \\
\hline 1992 & $\begin{array}{c}\text { Catequese Católica no Brasil: Para uma } \\
\text { História da Evangelização }\end{array}$ & Oscar de Figueiredo Lustosa \\
\hline 1993 & $\begin{array}{c}\text { Em Defesa da Vida: Vale a Pena a Pena } \\
\text { de Morte? }\end{array}$ & $\begin{array}{c}\text { Cendhec - Centro Dom } \\
\text { Helder Câmara de Estudos e } \\
\text { Ação Social }\end{array}$ \\
\hline 1993 & $\begin{array}{c}\text { Nova Evangelização e Maturidade } \\
\text { Afetiva }\end{array}$ & Alfonso García Rubio \\
\hline \multicolumn{3}{|c|}{ Pesquisa \& Projeto } \\
\hline 1982 & $\begin{array}{c}\text { Religião e Modos de Produção Pré- } \\
\text { Capitalistas }\end{array}$ & François Houtart \\
\hline
\end{tabular}

\footnotetext{
${ }^{388}$ Edição Conjunta Cehila.

${ }^{389}$ Tradução do original em espanhol: La Iglesia Católica durante la Construcción del Socialismo en Cuba.

${ }^{390}$ Edição Conjunta Cehila.
} 


\begin{tabular}{|c|c|c|}
\hline 1982 & $\begin{array}{c}\text { O Ser e o Messias: Um Estudo sobre o } \\
\text { Messianismo de Jesus }\end{array}$ & José Porfírio Miranda \\
\hline 1982 & O Direito dos Pobres & Wagner Balera \\
\hline 1983 & As Armas Ideológicas da Morte & Franz Hinkelammert \\
\hline 1983 & $\begin{array}{c}\text { Poder, Luta e Defesa: Teoria e Prática } \\
\text { da Ação Não-Violenta }\end{array}$ & Gene Sharp \\
\hline 1984 & Por Dever ou por Prazer? & Albert Plé \\
\hline 1984 & A Palavra Humilhada & Jacques Ellul \\
\hline 1986 & $\begin{array}{c}\text { Lugar Atual da Morte: Antropologia, } \\
\text { Medicina e Religião }\end{array}$ & François Hubert Lepargneur \\
\hline 1986 & Teologia Negra & $\begin{array}{c}\text { Gayraud S. Wilmore; James } \\
\text { H. Cone (org.) }\end{array}$ \\
\hline 1986 & Crítica à Razão Utópica & Franz Hinkelammert \\
\hline 1991 & $\begin{array}{c}\text { Maria e Iemanjá: Análise de um } \\
\text { Sincretismo }\end{array}$ & Pedro Iwashita \\
\hline \multicolumn{3}{|c|}{ Igreja Dinâmica } \\
\hline 1976 & $\begin{array}{l}\text { Qual é a sua Vocação? Roteiros Bíblicos } \\
\text { por frei Gilberto da Silva Gorgulho, op }\end{array}$ & $\begin{array}{l}\text { Paulo Evaristo Arns; } \\
\text { Gilberto da Silva Gorgulho }\end{array}$ \\
\hline 1977 & Comunidade, Líder, Paróquia & Rogério Alicino, pime \\
\hline 1979 & $\begin{array}{l}\text { Panela de Opressão. Juventude: da } \\
\text { Opressão do Cativeiro à Libertação }\end{array}$ & Walmir Fernandes Brandão \\
\hline 1982 & $\begin{array}{l}\text { Um Projeto de Deus: A Presença de } \\
\text { Deus no Meio do Povo Oprimido }\end{array}$ & Carlos Mesters \\
\hline 1982 & $\begin{array}{c}\text { Igreja e Ideologias na América Latina, } \\
\text { Segundo Puebla }\end{array}$ & $\begin{array}{l}\text { Francisco Antônio de } \\
\text { Andrade Filho }\end{array}$ \\
\hline 1982 & Juventude: O Grande Desafio & Pe. Jorge Boran, C. S. sp. \\
\hline 1985 & $\begin{array}{c}\text { CEBs: Uma Interpelação para o Ser } \\
\text { Cristão Hoje }\end{array}$ & $\begin{array}{c}\text { Henrique Cristiano José } \\
\text { Matos }\end{array}$ \\
\hline 1985 & $\begin{array}{c}\text { Formação Histórica da Religiosidade } \\
\text { Popular no Nordeste: O Caso de Juazeiro } \\
\text { do Norte }\end{array}$ & $\begin{array}{c}\text { Hermínio Bezerra de } \\
\text { Oliveira }\end{array}$ \\
\hline 1988 & Espiritualidade no Compromisso & Johan Konings \\
\hline
\end{tabular}




\begin{tabular}{|c|c|c|}
\hline 1989 & $\begin{array}{l}\text { O Segredo do Reino de Deus: Reflexões } \\
\text { sobre as Parábolas de Jesus }\end{array}$ & Bernardo Canal Feijoo \\
\hline 1992 & Opção Pelos Pobres Hoje & José Maria Vigil (coord.) ${ }^{391}$ \\
\hline 1993 & $\begin{array}{c}\text { Santo Domingo: Significação e } \\
\text { Silêncios: A IV Conferência do } \\
\text { Episcopado Latino Americano, 1992: } \\
\text { Leitura de um Ponto de Vista Leigo }\end{array}$ & Francisco Catão \\
\hline 1994 & $\begin{array}{c}\text { O Futuro Tem Nome: Juventude. } \\
\text { Sugestões Práticas para Trabalhar com } \\
\text { Jovens }\end{array}$ & Pe. Jorge Boran, C. S. sp. \\
\hline 1994 & $\begin{array}{l}\text { Curso de Treinamento para Liderança } \\
\qquad(\text { CTL })^{392}\end{array}$ & Pe. Jorge Boran, C. S. sp. \\
\hline \multicolumn{3}{|c|}{ Pastoral e Comunidade } \\
\hline 1976 & $\begin{array}{c}\text { Comunidade Eclesial de Base: } \\
\text { Prioridade Pastoral }\end{array}$ & $\begin{array}{c}\text { José Marins; Carolee } \\
\text { Chanona; Teolide Maria } \\
\text { Trevisan } \\
\text { T93 }\end{array}$ \\
\hline 1976 & $\begin{array}{c}\text { Igreja e Conflitividade na América } \\
\text { Latina. Reflexão Pastoral a Partir da } \\
\text { CEB }\end{array}$ & $\begin{array}{c}\text { José Marins; Carolee } \\
\text { Chanona; Teolide Maria } \\
\text { Trevisan }\end{array}$ \\
\hline 1977 & $\begin{array}{c}\text { Comunidade Eclesial: Instituição e } \\
\text { Carisma }\end{array}$ & $\begin{array}{c}\text { José Marins; Carolee } \\
\text { Chanona; Teolide Maria } \\
\text { Trevisan }\end{array}$ \\
\hline 1977 & $\begin{array}{c}\text { Modelos de Igreja: Comunidade Eclesial } \\
\text { de Base na América Latina }\end{array}$ & $\begin{array}{c}\text { José Marins; Carolee } \\
\text { Chanona; Teolide Maria } \\
\text { Trevisan }\end{array}$ \\
\hline 1977 & $\begin{array}{c}\text { Missão Evangelizadora da Comunidade } \\
\text { Eclesial }\end{array}$ & $\begin{array}{c}\text { José Marins; Carolee } \\
\text { Chanona; Teolide Maria } \\
\text { Trevisan }\end{array}$ \\
\hline
\end{tabular}

\footnotetext{
${ }^{391}$ Com textos de Pedro Casaldáliga, Victor Codina, Giulio Girardi, Julio Lois, Jorge Pisley, Jon Sobrino e Leonardo Boff.

${ }^{392}$ Estes dois últimos volumes já foram lançados sob a nova marca Paulinas, após a separação.

${ }^{393}$ Nas capas constam apenas "José Marins e Equipe", omitindo o nome das religiosas que compunham a equipe.
} 


\begin{tabular}{|c|c|c|}
\hline 1977 & $\begin{array}{c}\text { Práxis Profética: Profetas - Cristo- } \\
\text { Comunidade Eclesial }\end{array}$ & $\begin{array}{c}\text { José Marins; Carolee } \\
\text { Chanona; Teolide Maria } \\
\text { Trevisan }\end{array}$ \\
\hline 1977 & $\begin{array}{c}\text { Comunidade Eclesial de Base Na } \\
\text { América Latina: Origem, Conteúdo, } \\
\text { Perspectivas }\end{array}$ & $\begin{array}{c}\text { José Marins; Carolee } \\
\text { Chanona; Teolide Maria } \\
\text { Trevisan }\end{array}$ \\
\hline 1977 & $\begin{array}{c}\text { Realidade e Práxis na Pastoral Latino- } \\
\text { Americana }\end{array}$ & $\begin{array}{c}\text { José Marins; Carolee } \\
\text { Chanona; Teolide Maria } \\
\text { Trevisan }\end{array}$ \\
\hline 1979 & $\begin{array}{c}\text { Maria, Mulher Libertadora: Dinamismo } \\
\text { Mariológico na Comunidade Eclesial de } \\
\text { Base }\end{array}$ & $\begin{array}{c}\text { José Marins; Carolee } \\
\text { Chanona; Teolide Maria } \\
\text { Trevisan }\end{array}$ \\
\hline 1979 & $\begin{array}{c}\text { De Medellín a Puebla: A Práxis dos } \\
\text { Padres na América Latina }\end{array}$ & $\begin{array}{c}\text { José Marins; Carolee } \\
\text { Chanona; Teolide Maria } \\
\text { Trevisan }\end{array}$ \\
\hline 1980 & A Práxis do Martírio Ontem e Hoje & $\begin{array}{c}\text { José Marins; Carolee } \\
\text { Chanona; Teolide Maria } \\
\text { Trevisan }\end{array}$ \\
\hline 1980 & $\begin{array}{c}\text { Puebla e as Comunidades Eclesiais de } \\
\text { Base: O Que Foi Assumido e o Processo } \\
\text { Que Continua }\end{array}$ & $\begin{array}{c}\text { José Marins; Carolee } \\
\text { Chanona; Teolide Maria } \\
\text { Trevisan }\end{array}$ \\
\hline 1980 & $\begin{array}{c}\text { Metodologia Emergente das } \\
\text { Comunidades Eclesiais de Base }\end{array}$ & $\begin{array}{c}\text { José Marins; Carolee } \\
\text { Chanona; Teolide Maria } \\
\text { Trevisan }\end{array}$ \\
\hline 1980 & $\begin{array}{c}\text { Comunidades Eclesiais de Base: Foco de } \\
\text { Evangelização e Libertação }\end{array}$ & $\begin{array}{c}\text { José Marins; Carolee } \\
\text { Chanona; Teolide Maria } \\
\text { Trevisan }\end{array}$ \\
\hline 1980 & $\begin{array}{c}\text { D. Oscar A. Romero: Profeta da } \\
\text { Libertação }\end{array}$ & $\begin{array}{c}\text { José Marins; Carolee } \\
\text { Chanona; Teolide Maria } \\
\text { Trevisan }\end{array}$ \\
\hline 1982 & $\begin{array}{c}\text { Mudança Social na Comunidade Rural: } \\
\text { Estudo Sociológico a Partir de uma } \\
\text { Comunidade Eclesial de Base }\end{array}$ & $\begin{array}{c}\text { Maria do Carmo Costa } \\
\text { Oliveira }\end{array}$ \\
\hline
\end{tabular}




\begin{tabular}{|c|c|c|}
\hline 1982 & $\begin{array}{c}\text { A Mudança na Linha de Ação } \\
\text { Missionária Indigenista }\end{array}$ & Arlindo G. de O. Leite \\
\hline 1984 & $\begin{array}{c}\text { A Caminhada do Diaconato Permanente: } \\
\text { Teologia e Prática }\end{array}$ & Valter Maurício Goedert \\
\hline 1985 & $\begin{array}{c}\text { Pastoral Popular: A Igreja Que se } \\
\text { Renova }\end{array}$ & $\begin{array}{c}\text { José Marins; Carolee } \\
\text { Chanona; Teolide Maria } \\
\text { Trevisan }\end{array}$ \\
\hline 1986 & $\begin{array}{c}\text { A Paróquia Renovada: Participação do } \\
\text { Conselho de Pastoral Paroquial }\end{array}$ & Elias della Giustina \\
\hline 1986 & Testemunho de um Padre & Osmar O. de Resende \\
\hline 1986 & $\begin{array}{c}\text { Diaconato Permanente: Visão Histórica } \\
\text { e Situação Atual }\end{array}$ & Aury Azelio Brunetti \\
\hline 1986 & $\begin{array}{c}\text { Maria Libertadora na Caminhada da } \\
\text { Igreja }\end{array}$ & $\begin{array}{c}\text { José Marins; Carolee } \\
\text { Chanona; Teolide Maria } \\
\text { Trevisan }\end{array}$ \\
\hline 1988 & $\begin{array}{c}\text { Classes Sociais e Pastoral da Juventude: } \\
\text { Elementos para uma Pastoral da } \\
\text { Juventude dos Meios Específicos }\end{array}$ & $\begin{array}{l}\text { Luciano Mendes de Faria } \\
\text { Filho }\end{array}$ \\
\hline 1988 & Os Pobres da Terra: Desafios à Pastoral & Roy H. May \\
\hline 1988 & Da Periferia um Povo se Levanta & Helcion Ribeiro \\
\hline 1989 & Grupos de Jovens: Por Onde Começar? & Jerônimo Gasques \\
\hline 1989 & Mulher: Da Escravidão à Libertação & Hugues d'Arns (org.) $)^{394}$ \\
\hline \multicolumn{3}{|c|}{ Cadernos de Base } \\
\hline 1981 & $\begin{array}{c}\text { A Vida de Grupo nas Comunidades } \\
\text { Eclesiais de Base }\end{array}$ & - \\
\hline 1981 & Bate-Papo sobre Política [I] & Arquidiocese de Vitória \\
\hline 1981 & Encontro com Nossa Senhora & Arquidiocese de Vitória \\
\hline 1981 & Beabá do Sindicato & Arquidiocese de Vitória \\
\hline 1982 & $\begin{array}{c}\text { Bate-Papo sobre Política II: Como } \\
\text { Funciona a Sociedade? }\end{array}$ & Arquidiocese de Vitória \\
\hline
\end{tabular}

394 Textos de José Oscar Beozzo, Maria Geralda Resende, Teodoro Rohner e Jean-Pierre Barruel de Lagenest, além do próprio Hugues d'Arns. 


\begin{tabular}{|c|c|c|}
\hline 1982 & $\begin{array}{l}\text { Cartilha das Comunidades Eclesiais de } \\
\text { Base }\end{array}$ & - \\
\hline 1982 & A Eucaristia nas CEBS & Antônio Francisco Falconi ${ }^{395}$ \\
\hline 1982 & Eucaristia - Escola de Ministérios & - \\
\hline 1982 & $\begin{array}{l}\text { O Evangelho na Rua. Grupos de Rua: } \\
\text { Sementes de União }\end{array}$ & Antônio Francisco Falconi \\
\hline 1982 & $\begin{array}{c}\text { Grupos de Rua: Sementes de } \\
\text { Transformação }\end{array}$ & Antônio Francisco Falconi \\
\hline 1982 & As CEBs Celebram a Esperança & - \\
\hline 1982 & Assembleia das Comunidades & Antônio Francisco Falconi \\
\hline 1984 & $\begin{array}{c}\text { O Povo Descobre a Sociedade: } \\
\text { “Capitalismo X Socialismo”: Subsídio } \\
\text { para Reflexões de CEBS }\end{array}$ & $\begin{array}{c}\text { Equipe de Pastoral da } \\
\text { Diocese de Juazeiro, BA }\end{array}$ \\
\hline 1986 & Negro tem Valor & $\begin{array}{l}\text { Grupo de Trabalho contra a } \\
\text { Discriminação Racial }\end{array}$ \\
\hline 1986 & $\begin{array}{c}\text { Constituinte do Povo: Um Projeto de } \\
\text { Deus. Subsídio para Reflexão em Grupos }\end{array}$ & $\begin{array}{l}\text { Centro de Comunicação } \\
\text { Pastoral Popular }\end{array}$ \\
\hline
\end{tabular}

\subsection{Ler a Bíblia nas Comunidades Eclesiais de Base}

Em uma síntese a respeito da mediação editorial, Roger Chartier afirma que "a edição submete a circulação das obras a coerções e a finalidades que não são idênticas àquelas que governaram sua escrita" ${ }^{\natural 96}$. Talvez em nenhuma outra obra este postulado se faça tão evidente quanto na edição dos textos bíblicos.

\footnotetext{
${ }^{395}$ Padre, atuou em paróquias de Itaquera e São Miguel Paulista, na periferia Leste de São Paulo.

${ }^{396}$ CHARTIER, Roger. “A Mediação Editorial”. Os Desafios da Escrita. São Paulo, Editora Unesp, 2002, p. 76.
} 
Como afirmamos anteriormente, o Concílio Vaticano II determinava que os fiéis tivessem "acesso patente à Sagrada Escritura"397. No Brasil, o incentivo à leitura da Bíblia se fazia tão mais necessário devido ao contraste observado entre católicos e protestantes. Conforme as igrejas protestantes pentecostais - como Assembleia de Deus e Congregação Cristã no Brasil, presentes no país desde o início do século $\mathrm{XX}-\mathrm{e}$ neopentecostais - a maior, Universal do Reino de Deus, foi criada em $1977^{398}$ - se expandiam, seus membros marcavam uma presença cada vez mais visível nas cidades. Em especial nas periferias, onde o novo protestantismo cresceu de forma mais acelerada, a imagem de um fiel dirigindo-se a sua igreja portando uma Bíblia passou a ser associada aos protestantes. A proximidade com o livro sagrado conferia a eles, além de distinção social, uma distinção de ordem propriamente teológica - o contato direto com a Bíblia torna-se um elemento para legitimar o protestantismo como a religião mais fiel ao que seria o cristianismo original - acentuada pelo fato de se denominarem evangélicos. Se a questão remonta pelo menos a 1517 e, no Brasil, à chegada de protestantes como os presbiterianos no século XIX, nas periferias das grandes cidades brasileiras ela era uma novidade. Em sua pesquisa nas CEBs, na década de 1980, Carmen Macedo ouviu de um de seus entrevistados, protestante: “A verdade é a Bíblia. Nós temos a Bíblia. No espiritismo, não tem Bíblia; na católica tem, mas não levam na Igreja"399.

\footnotetext{
${ }^{397}$ PAULO VI. Constituição Dogmática Dei Verbum Sobre a Revelação Divina. Roma, 18 de novembro de 1965

398 Para Ricardo Mariano, a novidade neopentecostal é sua maior acomodação à sociedade contemporânea, com ritos de cura do corpo e das emoções, das soluções para os relacionamentos interpessoais, e, sobretudo após meados dos anos 1980, com a Teologia da Prosperidade, que oferece conforto material individual e/ou familiar (diferentemente da Teologia da Libertação, cujo meio e fim são coletivos). Cf. MARIANO, Ricardo. Neopentecostais: Sociologia do Novo Pentecostalismo no Brasil. São Paulo, Loyola, 1999. É preciso considerar, também, que as neopentecostais como a Universal e a Igreja Internacional da Graça de Deus têm uma estrutura organizacional distinta da Assembleia e da Congregação, funcionando como empresas, já que Edir Macedo e R. R. Soares não são apenas líderes, mas, de certa forma, "donos" de suas igrejas. Para um histórico da Teologia da Prosperidade, ver GARRARD-BURNETT, Virginia. "A Vida Abundante: A Teologia da Prosperidade na América Latina". História: Questões \& Debates, n. 55, vol. 2, 2011.

${ }^{399}$ MACEDO, Carmen Cinira de Andrade. Tempo de Gênesis: O Povo das Comunidades Eclesiais de Base, op. cit., p. 121.
} 
Mais do que na vida religiosa cotidiana, a expansão protestante ocorria também no mercado editorial, com destaque para as edições da Sociedade Bíblica do Brasil (SBB), baseadas na versão do século XVII de João Ferreira de Almeida, primeira tradução portuguesa dos originais ${ }^{400}$. Nesse sentido, a Bíblia de Jerusalém, lançada em versão integral pelas Edições Paulinas, em 1981, apresentava-se como um marco importante nessa disputa. Mas, além de editar, era preciso também estimular os católicos a possuírem suas próprias Bíblias e a tomarem para si tal distinção religiosa.

O esforço das Edições Paulinas em difundir não apenas a venda como também o uso cotidiano das Bíblias se nota pelos formatos em que elas eram publicadas. Uma lista de preço da editora de 1988, reproduzida abaixo, conta com cinco modelos da Bíblia de Jerusalém integral. Havia dois tamanhos, média e de bolso. Entre eles, o leitor poderia escolher entre a versão com índice no corte lateral, que facilitava a busca entre os livros, e a com zíper, que, fechando-se como uma bolsa, era ideal para ser transportada. Mais do que oferecer proteção, o zíper dispensava que o livro fosse guardado dentro de uma outra bolsa ou pasta. Assim, ao circular pela cidade, o católico poderia ostentar sua Bíblia em mãos.

O mesmo se dava com a edição mais tradicional, a tradução portuguesa de Matos Soares a partir da Vulgata. Mais popular, era vendida por cerca da metade do preço da Bíblia de Jerusalém. Além dos formatos de bolso, incluindo o volume protegido por uma capa zíper, havia uma versão com "letra e formato grande" pelo mesmo valor que a de bolso, o que sugere que essa edição, provavelmente dirigida a um público mais idoso, fosse impressa em papel de qualidade inferior e apresentasse uma encadernação mais modesta.

400 Cf. KONINGS, Johan. "Tradução e Traduções da Bíblia no Brasil". In: GOHN, Carlos \& NASCIMENTO, Lyslei (org.). A Bíblia e suas Traduções. São Paulo, Humanitas, 2009, pp. 103-104. 
Tabela 6. Lista de Preços de Bíblias das Edições Paulinas, 1988.

\begin{tabular}{|l|c|}
\hline \multicolumn{2}{|c|}{ A Bíblia de Jerusalém } \\
\hline Bolso & $\$ 5.500$ \\
\hline Bolso - zíper & $\$ 8.300$ \\
\hline Média - encadernada & $\$ 5.500$ \\
\hline Média - índice & $\$ 6.400$ \\
\hline Média - zíper & $\$ 11.000$ \\
\hline \multicolumn{2}{|c|}{ Bíblia Sagrada (trad. Matos Soares) } \\
\hline Letra e formato grande & $\$ 2.500$ \\
\hline Bolso - encadernada & $\$ 2.500$ \\
\hline Bolso - índice & $\$ 3.200$ \\
\hline Bolso - zíper & $\$ 4.400$ \\
\hline
\end{tabular}

Lista de Preços Edições Paulinas - Livros - n. 84 - 1988, p. 5. Disponível no Arquivo Nacional, Fundo SNI, Série Agência Central, Dossiê "Publicações Religiosas”, 1990. Os valores estão em Cruzados

$$
(C z \$)^{401} \text {. }
$$

Após o lançamento da Bíblia de Jerusalém, em 1981, as Edições Paulinas planejam mais uma edição da Bíblia. Como vimos na seção anterior, naquela década a editora voltou grande parte de sua atuação para a Teologia da Libertação e as comunidades eclesiais de base, inserindo, nos livros religiosos, questões políticas e sociais em uma chave de esquerda. Se esses livros abrangiam diversos aspectos da vida católica e se dirigiam a variados públicos, ainda faltava a obra religiosa mais importante. Assim, inicia-se o projeto da Bíblia Sagrada: Edição Pastoral, ou, simplesmente, Bíblia Pastoral.

\footnotetext{
401 Ainda em janeiro de 1990, o SNI (Serviço Nacional de Informações) organizou um último dossiê de investigações sobre as igrejas (católicas e protestantes) progressistas, que incluía seções especiais sobre editoras e livrarias religiosas. Dois meses depois, o SNI seria extinto, e faz-se necessária uma pesquisa à parte para verificar se os "órgãos de inteligência" que o sucederam não mantiveram a espionagem a religiosos e outros grupos por suas posições política. De qualquer forma, mesmo após a Constituição de 1988, os religiosos que exprimissem discursos considerados de esquerda eram tratados como potenciais ameaças ao Estado brasileiro.
} 
Diferentemente da Bíblia de Jerusalém, cujos paratextos foram traduzidos do francês, a Edição Pastoral foi um projeto brasileiro ${ }^{402}$. A direção editorial e a revisão exegética foi de José Bortolini. Padre atuante na região de Campo Limpo ${ }^{403}$, na periferia da cidade de São Paulo, ele era mestre pelo Pontifício Instituto Bíblico de Roma e, na década de 1980, estava com cerca de trinta anos. Naqueles mesmos anos, coordenou também a primeira revisão da Bíblia de Jerusalém (essa nova edição, revista, sai em 1985). A tradução, a introdução e as notas da Edição Pastoral foram do padre Ivo Storniolo e de Euclides Martins Balancin, ambos mestres pelo Pontifício Instituto Bíblico de Roma, assim como Bortolini e José Luiz Gonzaga do Prado, responsável pela tradução de alguns livros do Antigo Testamento - 1-2 Crônicas, Esdras, Neemias, Tobias, 1-2 Macabeus e Profetas. Gonzaga do Prado estudara na Europa e, de volta ao Brasil, assumiu uma paróquia em Nova Rezende, MG, na região de Passos, onde trabalhou com as comunidades eclesiais de base. O único paulino a participar diretamente do trabalho com o texto foi José Dias Goulart, a quem esteve a cargo a revisão literária. Goulart fora assessor de imprensa da CNBB na década de 1970 (cf. Capítulo 2) e, nos anos 1950, assim como os demais paulinos da época, fizera os estudos teológicos em Roma. No período de tradução da Bíblia Pastoral, Ivo Storniolo era coordenador da seção bíblica das Edições Paulinas.

Em 1986, é lançado o Novo Testamento: Edição Pastoral. A Bíblia completa veio a público em março de 1990 e, um mês depois, em abril, tem uma segunda impressão, à

\footnotetext{
402 Embora não a citem, é evidente a inspiração da Edición Pastoral Latinoamérica, ou Biblia Latinoamericana. Traduzida pelos chilenos Bernardo Hurault e Ramón Ricciardi, foi lançada em diversos países de fala espanhola a partir de 1972. Na Argentina, foi publicada pelas Ediciones Paulinas (que também se separou, no início dos anos 1990, em Editorial Paulinas e Editorial San Pablo). A Biblia Latinoamericana, além de notas e outros paratextos, trazia ilustrações e fotografias representando a Revolução Cubana, Martin Luther King e até o brasileiro Helder Câmara. Sofreu censuras e cortes da Congregação para a Doutrina da Fé e, após o golpe militar na Argentina em 1976, foi proibida. Em 2004, a Editorial San Pablo lançou uma nova edição, revista.

${ }^{403}$ A região pertencia à Arquidiocese de São Paulo até 1989, quando é desmembrada em diocese.
} 
qual tivemos acesso e nos remeteremos ${ }^{404}$. Essa Bíblia possui duas características principais. Primeiro, a tradução e os paratextos dos tradutores, revisores e editores se voltavam, como anuncia o título, à prática pastoral. Portanto, em linguagem um pouco simplificada se comparada às outras Bíblias, mas mantendo muitas opções de vocabulário próximas às da Bíblia de Jerusalém ${ }^{405}$ (portanto não tão simplificada, por exemplo, quanto a edição conhecida como Nova Tradução na Linguagem de Hoje). Segundo, e mais importante, por ser o elemento que a distingue de todas as outras Bíblias publicadas no Brasil, seus paratextos traziam uma interpretação política do texto bíblico, a partir da Teologia da Libertação. Assim, essa edição representava uma síntese entre a Teologia da Libertação, acadêmica e erudita, e a prática pastoral, cotidiana, da Igreja progressista mais à esquerda, chamada por Mainwaring de "Igreja Popular". A “Apresentação", assinada por "Os Editores", explicitava o público a que se destinava, assim como o objetivo discursivo motivado pela ideia de transformação: "Gostaríamos que seu uso fosse comunitário: o texto realmente foi preparado para ser início de diálogo entre a Palavra de Deus e a palavra dos homens, a fim de criar um novo mundo" ${ }^{\prime 406}$.

\footnotetext{
${ }^{404}$ Bíblia Sagrada. Edição Pastoral. 2. Impressão [abril de 1990]. São Paulo, Edições Paulinas, 1990.

${ }^{405}$ Embora a tradução tenha similaridades com a Bíblia de Jerusalém, a Edição Pastoral faz algumas escolhas diferentes, para simplificar e aumentar a clareza do texto. Por exemplo, ao invés de "o seu nome" usa-se por vezes "o nome dele". Johan Konings destaca a tradução, na Edição Pastoral, de YHWH por Javé, enquanto a Bíblia de Jerusalém utiliza Iahweh e a edição da Ave Maria "o Senhor", esta última também presente nas protestantes baseadas na versão de João Ferreira de Almeida (cf. KONINGS, Johan. “Traduções Bíblicas Católicas no Brasil (2000-2015)". Pistis \& Praxis: Teologia e Pastoral, vol. 8, n. 1, jan.-abr. 2016, p. 94).

${ }^{406}$ Idem, p. 5.
} 


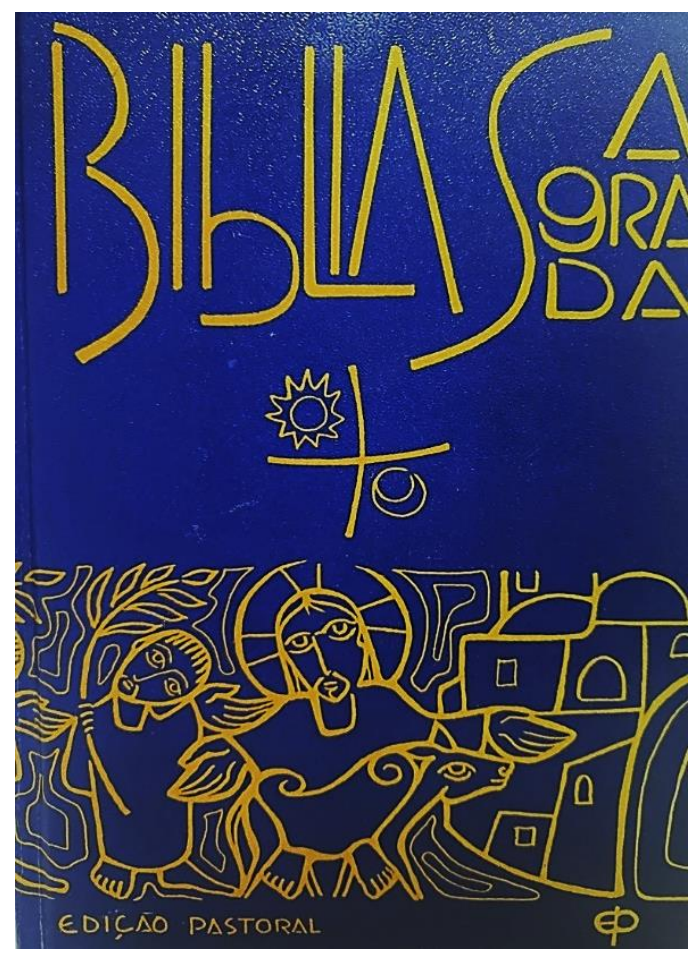

Figura 15. Bíblia Sagrada. Edição Pastoral. 2. Impressão [abril de 1990]. São Paulo, Edições Paulinas, 1990. A ilustração da capa, com o título "Caminhada para Jerusalém”, é de Cláudio Pastro.

Note-se que, nesta edição, o próprio logo EP tem seu estilo modificado, para acompanhar o projeto visual da capa: o emprego da letra de mão, com traços simples, remetendo a alguma espécie de alfabeto primitivo, sem serifas ou curvas elaboradas.

Não é nosso intuito, aqui, analisar ou comparar a tradução desta Bíblia, o que mereceria uma pesquisa à parte e exigiria conhecimentos linguísticos específicos, dos quais não dispomos e que, ademais, extrapolaria o escopo de nosso projeto. Vejamos, entretanto, algumas das intervenções e paratextos que contribuem, para além da tradução do texto, para transformar a Edição Pastoral em uma Bíblia com características muito específicas.

O primeiro elemento destoante é a presença de uma epígrafe, recurso incomum nas edições bíblicas. A citação foi tomada do literato e místico indiano Tagore, 
identificado com o anticolonialismo. Espécie de canção, o texto repetia um refrão sobre “os mais pobres, mais humildes e perdidos" 407.

A todos os livros bíblicos era atribuído um subtítulo específico (cf. Tabela 9). Esses subtítulos estavam, inclusive, presentes no sumário, o que reforça a ideia de que cada livro deveria ser lido sob aquela interpretação específica. Por exemplo, "Evangelho segundo S. Mateus: Jesus, o Mestre da Justiça", ou "Primeira Carta aos Coríntios: Como Superar os Conflitos na Comunidade"408.

As introduções eram múltiplas. Além de uma para cada livro, havia uma específica para o Novo e outra para o Antigo Testamento e, também, para os grandes grupos de livros, divididos em: Pentateuco, Livros Históricos, Outros Livros Históricos, Livros Sapienciais, Livros Proféticos, Evangelhos, Cartas de São Paulo (não há introdução para as outras cartas). Nesses textos introdutórios, é possível observar como a dimensão política e social, coletiva, é colocada sempre como oposta à espiritualidade intimista, tida como alienante. Na introdução aos Evangelhos, com o título “A Palestina no Tempo de Jesus", há comentários sobre a política, a economia e a religião do período. Assim concluem os autores, já respondendo às críticas que, sabiam, seriam a eles dirigidas:

\footnotetext{
407 “Aqui é o estrado para os teus pés, que repousam aqui, onde vivem os mais pobres, mais humildes e perdidos. Quando tento inclinar-me diante de ti, a minha reverência não consegue alcançar a profundidade onde os teus pés repousam, entre os mais pobres, mais humildes e perdidos. O orgulho nunca pode se aproximar desse lugar onde caminhas com as roupas do miserável, entre os mais pobres, mais humildes e perdidos. O meu coração jamais pode encontrar o caminho onde fazes companhia ao que não tem companheiro, entre os mais pobres, mais humildes e perdidos" (TAGORE. In: Bíblia Sagrada. Edição Pastoral, op. cit., p. 6). No início da década de 1990, as Edições Paulinas publicaram alguns livros de Tagore, como A Colheita, com tradução do próprio Ivo Storniolo, lançado no mesmo ano que a Bíblia Pastoral (1990). Mais tarde, mais títulos do autor sairiam tanto pela Paulus como pela Paulinas.

408 Notemos que essas intervenções remontam a uma longa história das traduções e edições dos textos bíblicos. Parece evidente, contudo, que em alguns contextos específicos, por exemplo, no que tange à tradução e edição do Novo e do Antigo Testamento da Bíblia por Lutero, o emprego da linguagem (um alemão acessível a todos, o qual, constituirá, inclusive, a base da língua moderna) e de recursos paratextuais e referenciais destinados a uma melhor identificação das passagens do texto adquirem um forte objetivo político. Essas disputas se evidenciam em outros projetos de edição e tradução para o vernáculo do texto sagrado, sobretudo na Idade Moderna. Sandro Ramon da Silva, ao observar a Bíblia Pastoral, faz um paralelo com as edições bíblicas que circulavam durante as revoluções inglesas do século XVII, também como "portadoras de ideias radicais" (SILVA, Sandro Ramon Ferreira da. O Tempo das Utopias. Religião e Romantismos Revolucionários no Imaginário da Teologia da Libertação dos anos 1960 aos 1990. Tese de doutorado em História Social, Universidade Federal Fluminense, 2013, pp. 74-75).
} 
Jesus nasceu, viveu e morreu dentro do contexto histórico do séc. I. Quando lemos o texto dos Evangelhos, devemos estar atentos para avaliar corretamente a sua atividade dentro da formação social, econômica, política e religiosa de seu tempo. Só assim a palavra e a ação de Jesus adquirirão o relevo concreto para que nós as entendamos melhor e possamos transpor toda a significação que há na pessoa de Jesus para os nossos dias. Não se trata de reduzir toda a mensagem de Jesus a nível sociopolítico. Mas nem de cair no oposto, reduzindo a mensagem de Jesus a nível individual e intimista ${ }^{409}$.

O mesmo se repete, por exemplo, na introdução aos Salmos:

Os salmos supõem o contexto maior de uma fé que nasce da história e constrói história. Seu ponto de partida é o Deus libertador que ouve o clamor do povo e se torna presente, dando eficácia à sua luta pela liberdade e vida (Ex 3, 7-8). Por isso, os salmos são as orações que manifestam a fé que os pobres e oprimidos têm no Deus aliado. Como esse Deus não aprova a situação dos desfavorecidos, o povo tem a ousadia de reivindicar seus direitos, denunciar a injustiça, resistir aos poderosos e até mesmo questionar o próprio Deus. São orações que nos conscientizam e engajam na luta dentro dos conflitos, sem dar espaço para o pieguismo, o individualismo ou a alienação ${ }^{410}$.

No período, a Renovação Carismática Católica (RCC) ganhava espaço no Brasil e, principalmente, nos meios de comunicação, incluindo os livros. Trata-se de uma tendência pentecostal, que acredita na manifestação dos dons do espírito santo (também chamados carismas), que, na Bíblia, incidem sobre os apóstolos no dia de Pentecostes (Atos dos Apóstolos, 2). Tendo como base os "grupos de oração", esse movimento atingiria sobretudo as classes médias conservadoras que não se sentiam incluídas no modelo das comunidades eclesiais de base. Moderna em relação aos meios de comunicação, a RCC é politicamente conservadora e tende a enfatizar as dimensões espiritual, individual e emocional da fé, privilegiando questões como saúde e sucesso

\footnotetext{
409 STORNIOLO, Ivo \& BALANCIN, Euclides Martins. "A Palestina no Tempo de Jesus". In: Bíblia Sagrada. Edição Pastoral, op. cit., p. 1237. Esse esforço de "contextualização" histórica era reforçado pela significativa quantidade de mapas: doze espalhados pelo livro, além de dois nas folhas de guarda. ${ }^{410}$ STORNIOLO, Ivo \& BALANCIN, Euclides Martins. "Salmos: A Oração do Povo de Deus. Introdução". In: Bíblia Sagrada. Edição Pastoral, op. cit., p. 671.
} 
individual e relacionamentos familiares ${ }^{411}$, em contraste com a Teologia da Libertação, tida como mais racional e cuja mobilização se fazia antes pela comunidade (bairro, paróquia etc.) que pelo núcleo familiar, privilegiando a "libertação coletiva" $" 12$. Por isso, o "individualismo e alienação" de que falam os tradutores da Bíblia Pastoral tinha também como alvo a RCC, que ocupava cada vez mais espaço. As próprias Edições Paulinas chegaram a publicar títulos ligados à RCC, que, embora não fossem numerosos, tinham grande volume de vendas, contando com muitas reedições ${ }^{413}$. Conjuntamente, as introduções, intertítulos e notas de rodapé da Bíblia Pastoral formam uma interpretação coesa. Por exemplo, o final do capítulo 13 do Apocalipse (vv. 11-18), sobre a primeira e a segunda "Bestas" e sua marca, recebe dos tradutores e

\footnotetext{
${ }^{411}$ Para um estudo a respeito do histórico da RCC e de suas crenças e práticas religiosas, como os grupos de oração, ver PRANDI, Reginaldo. Um Sopro do Espírito: A Renovação Conservadora do Catolicismo Carismático. 2. ed. São Paulo, Edusp/Fapesp, 1998. A "modernização" ou "renovação" conservadora é característica da Igreja Católica nesse momento. Tal era a posição, por exemplo, de João Paulo II, que inovou em diversos aspectos formais e comunicacionais, mantendo-se bastante conservador em relação à estrutura eclesiástica, à doutrina e à política.

${ }^{412}$ Essa tendência das comunidades eclesiais de base a deixarem em segundo plano os problemas da esfera íntima (em contraposição às esferas pública e privada, nos termos de HABERMAS, Jürgen. Mudança Estrutural da Esfera Pública, op. cit.) costuma ser explicação recorrente para a perda de membros, ao longo das décadas, para os movimentos pentecostais católicos (no caso das classes médias tradicionais e pouco afeitas à "opção preferencial pelos pobres") e, sobretudo, para os protestantes, em especial os chamados neopentecostais (no caso das classes trabalhadoras), como a Igreja Universal do Reino de Deus.

${ }^{413}$ Em 1976, os paulinos assinam um contrato para a publicação da tradução de Speak Lord, Your Servant is Listening: A Daily Guide to Scriptural Prayer. De autoria de David. E. Rosage, padre católico ligado à Renovação Carismática, o livro fora publicado nos Estados Unidos em 1970 pela Servant Books. Os direitos de tradução para o português foram cedidos à Comissão Nacional de Serviço da Renovação Carismática Católica, representada, no contrato com as Edições Paulinas, por Eduardo Dougherty. No Brasil, o livro seria lançado no mesmo ano como Oração Diária com a Bíblia na coleção Aprendendo a Orar, dedicada a livros de oração. Em 1981, Oração Diária com a Bíblia já contava com seis edições; em 1992, com onze. Além desse e outros livros de Rosage, havia na coleção volumes de Robert DeGrandis, também da RCC, como Os Dez Mandamentos da Oração, também de grande sucesso editorial. A estes, mesclavam-se na coleção autores de outras correntes, tais como Francisco Jalics e Jacques Loew. Além da coleção Aprendendo a Orar, que não era exclusivamente sobre a RCC, havia uma de nome Renovação Carismática, da qual foram encontrados apenas três títulos, e a Caminhos do Espírito. Ambas contavam apenas com livros traduzidos do inglês, italiano, francês e espanhol. Desta última, um dos maiores sucessos foi A Cura Interior, de Michael Scanlan, padre católico dos Estados Unidos. A obra contava com prefácio de Haroldo J. Rahm, missionário texano radicado no Brasil, um dos primeiros promotores da RCC no país. Rahm publicou pelas Edições Paulinas, entre outros, Novena do Espírito Santo: A Cura do Coração (em coautoria com Maria J. R. Lamego), que somente entre 1976 e 1992 teve quinze edições. Como a RCC e seus primeiros nomes atuantes no Brasil vinham dos Estados Unidos, a ela acabava se estendendo a crítica "antiimperialista" feita aos protestantes neopentecostais (ver, por exemplo, LIMA, Delcio Monteiro de. Os Demônios Nascem do Norte. Rio de Janeiro, Francisco Alves, 1987; autor citado, por exemplo, por Iraci Maria Didoné para contrapor a "Igreja popular" às correntes intimistas, que seriam, além de tudo, imperialistas).
} 
editores o título "A ideologia a serviço do poder". As notas explicativas a esse trecho identificam a primeira Besta com os poderes políticos "totalitários, ditatoriais e opressores" e a segunda com "a propaganda ideológica, que sustenta os poderes absolutos" ${ }^{\natural 14}$. Sobre essa última, outra nota afirma:

Como os profetas, a propaganda promete grandes milagres e mudanças, mas falsamente. Para sustentar os poderes e impor respeito e até mesmo adoração, a propaganda multiplica a imagem dos poderosos, fazendo crer que são onipresentes e vigilantes. Graças à manipulação, a segunda Besta controla a ação (mão direita) e o pensamento (fronte) de toda a sociedade (todas as categorias sociais). Para poder participar da economia (comprar e vender), todo mundo deve pensar e agir de acordo com a primeira Besta. Esse nivelamento de todas as classes sociais com o mesmo pensamento e ação é uma paródia do Reino de Deus ${ }^{415}$.

Os títulos eram atribuídos aos capítulos ou a trechos que compusessem uma unidade. A Edição Pastoral assim traduz a passagem do evangelho de Mateus sobre o fermento na massa:

O Reino transforma - Jesus contou-lhes ainda outra parábola: "O Reino do Céu é como o fermento que uma mulher pega e mistura com três porções de farinha, até que tudo fique fermentado" $" 416$.

O título "O Reino transforma", em itálico e negrito no original, é acrescentado pelos tradutores e editores, que, ao nomear as passagens, ordenam a Bíblia segundo uma lógica específica. Já a nota de rodapé referente ao versículo esclarece a que tipo de transformação se referiam: “A comunidade dos discípulos parece desaparecer no meio dos homens. Num segundo momento, porém, ela exerce ação transformadora no seio da sociedade"417. O trecho sobre o fermento na massa se repete em Lucas 20:13. Ali, os

\footnotetext{
${ }^{414}$ Bíblia Sagrada. Edição Pastoral, op. cit., pp. 1602-1603.

${ }^{415}$ Idem, p. 1603.

${ }^{416}$ Mateus 13:33. Bíblia Sagrada. Edição Pastoral, op. cit., pp. 1256-1257.

${ }^{417}$ Idem, p. 1256.
} 
anotadores remetem a outra nota de rodapé, que assim afirma: "Diante das estruturas e ações deste mundo, a atividade de Jesus e daqueles que o seguem parece impotente, e mesmo ridícula. Mas ela crescerá, até atingir o mundo inteiro"418. Tratava-se, portanto, não apenas de uma transformação espiritual do homem e do mundo, mas de uma transformação da sociedade.

Entre todos os elementos da primeira edição da Bíblia Pastoral, o que mais suscitou polêmicas foi o glossário presente no final. Tais eram os verbetes do "Pequeno Vocabulário":

Aliança, Alienação, Amor, Autoridade, Auto-Suficiência, Campo, Celebração, Cidade, Comércio, Compaixão, Comunidade, Conflito, Consciência, Conversão, Corrupção, Dinheiro, Direito, Discernimento, Dominação, Educação, Encarnação, Escravidão, Esperança, Exploração, Fé, Fraternidade, Gratidão, Herança, História, Idolatria, Injustiça, Integridade, Javé, Jesus, Julgamento, Justiça, Lei, Liberdade, Libertação, Liderança, Lucro, Memória, Morte, Oprimido, Ordem, Partilha, Páscoa, Paz, Perseguição, Pobre, Poder, Porta da Cidade, Povo de Deus, Produção, Projeto de Deus, Propriedade, Reino de Deus, Repressão, Ressurreição, Revelação, Riqueza, Roubo, Sabedoria, Salário, Santidade, Serviço, Sociedade, Temor de Deus, Trabalho, Tradição, Tribulação, Tribunal, Tributo, Utopia, Verdade, Vida, Violência ${ }^{419}$.

Todas as suas definições eram de caráter político e interpretavam inclusive os conceitos mais propriamente religiosos pelo viés da crítica à exploração social econômica, muito inspirada pelo marxismo. Por exemplo:

ALIANÇA: É o centro da Bíblia. Deus se alinha com os pobres e oprimidos para construir uma sociedade e uma história voltadas para a vida. Primeiramente vivida por um povo (Antigo Testamento), a Aliança foi proposta por Jesus a todos (Novo Testamento).

${ }^{418}$ Idem, p. 1286.

${ }^{419}$ Bíblia Sagrada. Edição Pastoral, op. cit., pp. 1616-1623. 
ALIENAÇÃO: Tudo aquilo que dificulta ou impede o povo de se tornar autor consciente na construção da sociedade e da história. É o primeiro efeito da ação demoníaca.

COMÉRCIO: Atividade econômica fundamental da cidade, destinada a distribuir a produção. A intermediação gera a figura do lucro, que produz ao mesmo tempo exploração e riqueza. No projeto de Deus, o comércio tende a ser superado pela partilha e gratuidade.

DINHEIRO: Equivalente simbólico de alguma coisa preciosa usado para agilizar a troca de bens. Tomado como fim em si mesmo gera acumulação de riquezas, tornando-se ídolo que usurpa o lugar de Deus.

ENCARNAÇÃO: Centro da fé cristã. Deus encarna-se na vida e na história humanas, mostrando o valor inestimável que elas têm diante dele. A coerência com a fé exige que nos encarnemos também, para que o projeto de Deus transforme as estruturas políticas e econômicas, dirigindo a história para a liberdade e a vida.

LIBERTAÇÃO: Acontecimento fundante do povo de Deus. Supõe que se tome consciência da escravidão e que se procure sair dela, a fim de construir uma sociedade alternativa, onde haja liberdade e vida para todos. O movimento popular em busca da libertação necessita de liderança que organize eficazmente a luta contra o opressor.

LUCRO: Ganho conseguido graças ao mau pagamento do trabalho. Em geral, é empregado no desenvolvimento tecnológico e científico, que é pago pelo trabalhador, embora seja este quem menos usufrui dele. Todas as grandes fases de desenvolvimento econômico ocultam esse desvio, que enriquece a poucos e empobrece a maioria.

VIOLÊNCIA: Pressão exercida para manter determinada situação ou transformá-la. O sistema injusto exerce contínua violência institucionalizada sobre o povo, reduzindo-o à fraqueza e impotência. Diante disso, temos a contraviolência daqueles que resistem para se defender do sistema opressor e conseguir a justiça e a paz ${ }^{420}$.

Embora textos do mesmo caráter estivessem presentes em inúmeras publicações católicas, por se tratar de uma Bíblia esse vocabulário despertou insatisfação da hierarquia. Ainda mais porque, se as notas de rodapé estavam espalhadas pelas páginas,

\footnotetext{
${ }^{420}$ Idem, p. 1616. Os conceitos que possuíssem definição no vocabulário eram indicados por asteriscos; e, ao final de cada verbete, havia ainda remissão a versículos bíblicos. Tanto os asteriscos quanto as remissões foram suprimidos aqui.
} 
chamando menos atenção do leitor, o vocabulário reunia ao final do livro todas essas definições de forma destacada. Um editor paulino afirma que Luciano Mendes de Almeida, então presidente da CNBB, foi pessoalmente à sede das Edições Paulinas solicitar que o vocabulário fosse removido ${ }^{421}$. A edição original passara por três reimpressões (abril e agosto de 1990, março de 1991). A quinta impressão, de junho de 1992, já traz as alterações impostas pela CNBB e um novo Imprimatur, desta vez do próprio Luciano Mendes de Almeida ${ }^{422}$. Apenas o "Pequeno Vocabulário" é removido, enquanto os demais paratextos (subtítulos, introduções e notas) são mantidos.

Considerando que a Edição Pastoral da Bíblia foi propriamente um projeto editorial, isto é, com propósitos bem estabelecidos, mobilizou diversos agentes em torno de si e se estendeu por anos, ela não foi publicada de forma isolada, já que outros livros foram produzidos para formar com ela uma unidade editorial, religiosa e política. Esses outros livros visavam, sobretudo, a popularização da leitura da Bíblia. Pode-se dizer, inclusive, que tal projeto se iniciou antes mesmo da publicação da Bíblia Pastoral.

Na linha da Teologia da Libertação ${ }^{423}$, a coleção Por Trás das Palavras ${ }^{424}$, organizada pelo frade carmelita Carlos Mesters ${ }^{425}$ e pelo instituto que este coordenava (Cebi - Centro de Estudos Bíblicos) no início da década de 1980, explicava questões bíblicas buscando se aproximar do leitor, assumindo que este fosse um trabalhador urbano ou rural. De autoria de Carlos Mesters, o primeiro volume foi Bíblia: Livro Feito em

\footnotetext{
${ }^{421}$ Depoimento de Luiz Miguel Duarte, 4.4.2019.

${ }^{422} \mathrm{O}$ primeiro, presente nas quatro primeiras impressões, havia sido concedido por Vital J. G. Wildernik, "Bispo de Itaguaí, responsável na CEP da CNBB pela Linha 3 - Catequese" (Bíblia Sagrada. Edição Pastoral, op. cit.). CEP refere-se a Conselho Episcopal de Pastoral.

423 Já na mesma linha, mas ainda em formato mais tradicional e abordando as questões sociais de forma menos explícita, em 1976 fora lançado o Curso Bíblico para as Comunidades Eclesiais de Base, que incentivava a leitura da Bíblia da editora: “A melhor tradução em língua portuguesa, como também a edição mais rica e precisa em notas e introduções, é A Bíblia de Jerusalém, cujo Novo Testamento acaba de ser publicado por EDIÇÕES PAULINAS" (d'ABLEIGES, Pe. Xavier G. de M. Curso Bíblico para as Comunidades Eclesiais de Base. São Paulo, Edições Paulinas, 1976, p. 7).

${ }^{424}$ Carlos Mesters já havia publicado pela Vozes, em 1974, o livro Por Trás das Palavras: Um Estudo sobre a Porta de Entrada no Mundo da Bíblia.

${ }^{425}$ Nascido na Holanda e residente no Brasil desde a juventude, Mesters estudara em Roma e na Escola Bíblica de Jerusalém.
} 
Mutirão. O sucesso foi imediato: saiu pela primeira vez no Brasil em 1983 e, em 1988, já atingia a $12^{\mathrm{a}}$ edição ${ }^{426}$ (de acordo com os editores). Foi traduzido para o espanhol, francês e inglês pelas editoras paulinas da Bolívia, do Canadá e da Índia ${ }^{427}$. Diferente da Bíblia de Jerusalém, que foi publicada por grupos diversos em cada país, este é um caso exemplar da circulação de traduções entre as diversas editoras paulinas ao redor do mundo.

Bíblia: Livro Feito em Mutirão consistia em um caderno de 32 páginas grampeado, e o material da capa era apenas um pouco mais resistente que o miolo - por isso, era um dos títulos mais baratos do catálogo. Em 1988, custava Cz\$250. Para fins de comparação, naquele mesmo ano o livro mais popular de Padre Zezinho (Essa Juventude Magnífica e seus Namoros Nem Sempre Maravilhosos) era vendido por Cz\$1.200 e a edição mais barata da Bíblia, por $\mathrm{Cz} \$ 2.500^{428}$.

A capa das edições até $1993^{429}$, reproduzida abaixo, estampava uma fotografia com cerca de vinte homens e meninos trabalhando em uma obra, portando pás e carrinhos de mão. A forma como ostentam as ferramentas e como sorriem para a foto transmite a ideia de orgulho e alegria pelo seu trabalho, que não seria feito em prol de um outro (isto é, de um patrão), mas de si mesmos, como em um mutirão.

\footnotetext{
${ }^{426}$ De acordo com as informações que constam nos exemplares. Não foi possível verificar se o número corresponde à realidade ou se compõe parte do marketing do livro.

${ }^{427}$ Biblia, El Libro del Pueblo de Diós. Bolivia, Ediciones Paulinas, 1983; La Bible, Un Livre Fait en Corvée. Montreal, Éditions Paulines, 1988; God at Work: The Presence of God amid the Oppressed People. Bombay, Pauline Sisters Bombay Society, 1994.

${ }^{428}$ Lista de Preços Edições Paulinas - Livros - n. 84 - 1988, p. 5. Disponível no Arquivo Nacional, Fundo SNI, Série Agência Central, Dossiê "Publicações Religiosas", 1990.

${ }^{429}$ A partir de então, passa a ser publicado pela Paulus com uma nova capa, que mostra apenas uma mão segurando uma bíblia antiga, com a encadernação corroída pelo uso.
} 


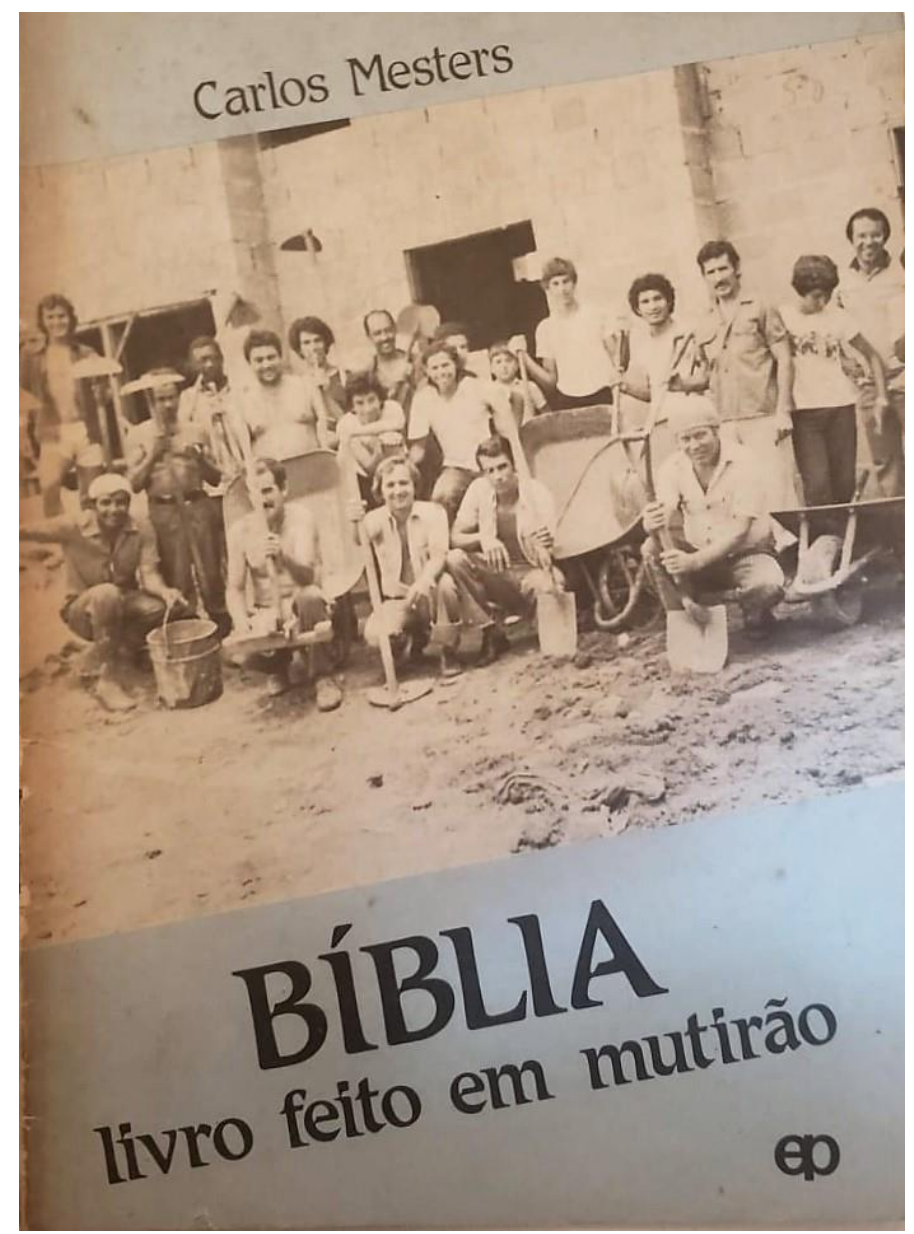

Figura 16: $1^{a}$ Capa de Carlos Mesters, Bíblia: Livro Feito em Mutirão. São Paulo, Edições Paulinas, 1983. (Por Trás das Palavras).

Já na primeira página, o autor fazia uso de metáforas do mundo do trabalho (como lembrou Leminski, na epígrafe deste capítulo, sobre as metáforas da Bíblia atribuídas a Jesus):

A Bíblia é como coco de casca dura. Esconde e protege uma água que mata a sede do romeiro cansado. Romeiros e peregrinos somos todos! Cansados também! Vamos procurar o facão que nos quebre a casca deste coco $!^{430}$

${ }^{430}$ MESTERS, Carlos. Bíblia: Livro Feito em Mutirão. São Paulo, Edições Paulinas, 1983. (Por Trás das Palavras), p. 3. 
Mas o livro, é claro, privilegiava os aspectos propriamente religiosos. Considerava a Bíblia como escrita pelo povo, por pessoas comuns que tiveram entre elas a presença de Deus; sua leitura colocaria o homem contemporâneo em contato com o Espírito de Deus ${ }^{431}$. Após a "longa caminhada" do Antigo Testamento, Jesus vem trazer a boa nova que faz o povo compreender o verdadeiro sentido da caminhada, que seria, em suma, a libertação de seu povo - os "oprimidos" contra os "poderosos", já que estes últimos estabeleceram uma sociedade injusta, oposta à vontade divina. Continua Mesters: da mesma forma que a vinda de Jesus iluminou os homens de seu tempo, hoje a Bíblia pode nos ajudar a compreender e a "transformar toda a realidade numa grande revelação de Deus" ${ }^{\text {432 }}$, desde que fosse lida e colocada em prática. Aí encerram-se os elementos mais socialmente críticos do livro, nas categorias de "oprimidos", "justiça" e "fraternidade", pois seu grande objetivo era, de fato, apresentar a Bíblia como algo interessante, que merecia ser lido - mais do que isso, os fiéis deveriam se reunir para ler a Bíblia.

Nas cinco seções em que o texto era dividido - que não são chamadas de capítulos, mas de "assuntos": Primeiro Assunto, Segundo Assunto etc. -, Mesters realizava, primeiro, uma introdução geral à Bíblia, explicando como eram divididos seus livros, quando e onde foi produzida; depois, incentivava sua leitura e estudo. Como em outras publicações, ao final de cada capítulo havia "Perguntas para continuar a reflexão", que também sugeriam atividades, por exemplo "pode-se copiar esta mensagem num caderno e/ou fazer um cartaz"433.

Essas atividades aparecem porque o texto buscava estimular a leitura não apenas individual, mas coletiva da Bíblia, isto é, "em comunidade”, nos Círculos Bíblicos: método popular de estudo da Bíblia cujo principal elaborador foi Carlos Mesters ${ }^{434}$.

\footnotetext{
${ }^{431}$ Idem, pp. 7-9.

${ }^{432}$ Idem, p. 29

${ }^{433}$ Idem, p. 22.

${ }^{434}$ Cf. BETTO, Frei. O Que É Comunidade Eclesial de Base. São Paulo, Brasiliense, 1981. (Primeiros Passos, 19).
} 
Incorporando ideias do método de Paulo Freire (principalmente a adaptação à realidade do trabalhador $)^{435}$, os Círculos eram realizados sobretudo nas comunidades eclesiais de base $^{436}$. Essa leitura poderia ser feita por todos, sem exigências de conhecimento acadêmico prévio, mas deveria seguir a interpretação da "comunidade", que não se restringia à paróquia:

\begin{abstract}
A Bíblia nasceu dentro de uma comunidade de fé. É só com o olhar de fé da comunidade que pode ser captada e entendida plenamente a mensagem da Bíblia. Este olhar de fé da comunidade não se compra com dinheiro nem se adquire só com estudo. Adquire-se vivendo na comunidade, participando de sua caminhada e das suas lutas. Mesmo quando leio a Bíblia sozinho, devo lembrar sempre que estou lendo o livro da comunidade. Ninguém tem o direito de interpretar a Bíblia do jeito que convém só a ele mesmo, contrário aos interesses da comunidade. Pois a Bíblia não é propriedade privada de ninguém, nem dos sábios e dos doutores. Ela foi entregue aos cuidados do povo de Deus ${ }^{437}$, para que este realize a sua missão libertadora, e revele aos olhos de todos a presença de Javé, o Deus vivo e verdadeiro. Com outras palavras, a Bíblia deve ser interpretada de acordo com o sentido que lhe dá a comunidade, a Igreja. O modo de pensar das comunidades do Brasil e da América Latina foi resumido em Medellín e em Puebla. O modo de pensar das comunidades do mundo inteiro é definido pelos Concílios Ecumênicos e pela palavra autorizada dos Papas ${ }^{438}$.
\end{abstract}

\footnotetext{
${ }^{435}$ O próprio Paulo Freire via no que ele chama de "Igreja Profética, utópica e esperançosa" (isto é, a Igreja mais progressista das comunidades eclesiais de base) uma oportunidade de colocar em prática uma educação libertadora, desde que fosse revolucionária (e não conciliadora), profética (sem se "secularizar", ou seja, mantendo os elementos religiosos da utopia) e que incorporasse os conhecimentos das ciências sociais para a compreensão da realidade (cf. FREIRE, Paulo. Os Cristãos e a Libertação dos Oprimidos. Lisboa, Edições Base, 1978, pp. 40-46). É preciso lembrar, também, a importância que tivera o MEB, Movimento de Educação de Base, na década de 1960. No MEB, iniciado pela CNBB e levado a cabo pelos setores da juventude de esquerda católica, a alfabetização e a formação política eram concomitantes. Sobre isso, ver, entre outros, FÁVERO, Osmar. "MEB - Movimento de Educação de Base. Primeiros Tempos: 1961-1966”. V Encontro Luso-Brasileiro de História da Educação, Évora, 5 a 8 de abril de 2004.

${ }^{436}$ Além de método, um "círculo bíblico" podia se referir também ao próprio grupo, que por vezes se reunia somente para o estudo e não chegava a formar uma "comunidade eclesial de base" propriamente dita (cf. CANTARELA, Antônio Geraldo. "Tradução de Textos Bíblicos para a Linguagem Popular: A Experiência do Centro Bíblico de Belo Horizonte”. Perspectivas Teológicas, Belo Horizonte, vol. 52, n. 1, jan.-abr. 2020). Uma distinção clara, a nosso ver, não somente exigiria fontes muito específicas, como talvez se mostrasse infundada, já que as CEBs eram em si muito distintas e podiam compreender somente reuniões para leitura da Bíblia. O próprio entendimento das CEBs representa uma lacuna na historiografia, já que, mesmo pela limitação das fontes, faltam trabalhos sistemáticos a seu respeito.

${ }^{437}$ Lembremos que o Concílio Vaticano II estabeleceu o conceito de "Igreja" como "Povo de Deus".

${ }^{438}$ MESTERS, Carlos. Bíblia: Livro Feito em Mutirão, op. cit., p. 31. Grifos do original.
} 
Assim, Mesters expande "comunidade" para a própria Igreja. Se, por um lado, todos podiam ler a Bíblia e a interpretação devia ser feita "a partir do povo crente e oprimido que hoje busca a sua libertação" 439 , por outro, ela devia seguir diretrizes ("o modo de pensar") estabelecidas pela hierarquia eclesiástica. Em outra passagem, afirma que "não se pode manipular o texto em favor das próprias ideias, como os judeus o faziam" ${ }^{440}$. O livro se propunha a circunscrever limites dentro dos quais a Bíblia (e, por extensão, a religião católica) poderia ser utilizada. Isso excluía tanto os protestantes quanto as leituras mais radicais ou secularizantes, já que Mesters insistia, também, no aspecto ritualístico da leitura em comunidade:

A interpretação da Bíblia não depende só da inteligência e do estudo, mas também do coração e da ação do Espírito Santo. [...] $a$ leitura da Bíblia deve ter os seus momentos de silêncio e de oração, de canto e de celebração, de troca de experiência e de vivências ${ }^{441}$.

Dessa forma, ao mesmo tempo que incorporava uma estética dos movimentos populares e categorias da teologia da libertação, que atraía, por exemplo, os agentes de pastoral das comunidades mais politizadas, a essência de Bíblia: Livro Feito em Mutirão estava na leitura católica e ritualizada da Bíblia, restrita a uma interpretação específica, isto é, aquela aprovada pelos bispos e pelo Vaticano.

Como vemos na tabela abaixo, a coleção Por Trás das Palavras não teve novos volumes entre 1988 e 1991 (apenas reedições de alguns títulos, como Bíblia: Livro Feito em Mutirão). A partir de 1991, um ano após o lançamento da Bíblia Pastoral, são lançados novos volumes sobre personagens e livros específicos.

\footnotetext{
${ }^{439}$ Idem, ibidem.

${ }^{440}$ Idem, p. 26.

${ }^{441}$ Idem, p. 32. Grifos do original.
} 
Tabela 7. Coleção Por Trás das Palavras

\begin{tabular}{|c|c|c|}
\hline Ano & Título & Autor \\
\hline 1983 & Bíblia: Livro Feito em Mutirão & Carlos Mesters \\
\hline 1983 & $\begin{array}{c}\text { Esperança de um Povo que Luta: O Apocalipse } \\
\text { de São João. Uma Chave de Leitura }\end{array}$ & Carlos Mesters \\
\hline 1983 & Estudo sobre Isaías Júnior & Carlos Mesters \\
\hline 1983 & Carta aos Romanos & Cebi \\
\hline 1983 & $\begin{array}{c}\text { E a Vida Vira Oração. Como Rezar os Salmos } \\
\text { a Partir do Povo }\end{array}$ & $\begin{array}{c}\text { Marcelo de Barros Souza; } \\
\text { Cebi }\end{array}$ \\
\hline 1983 & Comentário aos Atos dos Apóstolos & Cebi \\
\hline 1984 & $\begin{array}{c}\text { O Caminho Feito pela Palavra: Para Ajudar } \\
\text { na Leitura dos Atos dos Apóstolos }\end{array}$ & Eliseu Hugo Lopes \\
\hline 1985 & Rute: Uma História da Bíblia ${ }^{442}$ & Carlos Mesters \\
\hline 1986 & $\begin{array}{c}\text { Os Dez Mandamentos: Ferramenta de } \\
\text { Comunidade }\end{array}$ & Carlos Mesters \\
\hline 1986 & Bíblia, Livro da Aliança (Êxodo, 1924) & Carlos Mesters \\
\hline 1987 & $\begin{array}{c}\text { O Profeta Elias: Homem de Deus, Homem do } \\
\text { Povo }\end{array}$ & $\begin{array}{c}\text { Carlos Mesters; Wolfgang } \\
\text { Gruen }\end{array}$ \\
\hline 1988 & Salmos: A Oração do Povo que Luta & $\begin{array}{l}\text { Ivo Storniolo; José } \\
\text { Bortolini; Euclides } \\
\text { Martins Balancin }\end{array}$ \\
\hline 1988 & $\begin{array}{c}\text { Vida Viva: Os Salmos para Escolas e Grupos } \\
\text { de Jovens }\end{array}$ & Francisco Marques \\
\hline 1991 & $\begin{array}{c}\text { Paulo Apóstolo, um Trabalhador que Anuncia } \\
\qquad \text { o Evangelho }\end{array}$ & Carlos Mesters \\
\hline 1992 & $\begin{array}{l}\text { O Profeta Jeremias: Boca de Deus, Boca do } \\
\text { Povo. Uma Introdução à Leitura do Livro do } \\
\text { Profeta Jeremias }\end{array}$ & Carlos Mesters \\
\hline 1993 & $\begin{array}{c}\text { O Evangelho dos Sem-Teto: Uma Leitura da } \\
\text { Primeira Carta de Pedro }\end{array}$ & $\begin{array}{l}\text { Paulo Augusto de Souza } \\
\text { Nogueira }\end{array}$ \\
\hline
\end{tabular}

${ }^{442}$ A capa trazia ainda uma espécie de lema abaixo da fotografia: "Pão, Família, Terra! Quem vai por aí não erra!". 
Desde 1971, a Arquidiocese de Belo Horizonte promovia o "Mês da Bíblia", do qual participava, entre outros, Carlos Mesters. Ao longo da década, o projeto se expande e, em 1978, os membros passam a redigir o semanário Bíblia-Gente, editado pelos paulinos. De acordo com Antônio Geraldo Cantarela,

Em razão da grande demanda por subsídios que ajudassem na leitura popular da Bíblia, a equipe do Centro Bíblico de Belo Horizonte, com o suporte técnico de Edições Paulinas, propôs-se o desafio de produzir roteiros bíblicos que tivessem alcance nacional. Nasceu assim, em 1978, o semanário Bíblia - Deus Caminhando com a Gente, mais conhecido como Bíblia-Gente. A equipe era formada, então, por Alberto Antoniazzi (in memoriam), padre da Arquidiocese de Belo Horizonte, Wolfgang Gruen, padre salesiano, Inês Broshuis, do Instituto Secular Unitas, Antonio Geraldo Cantarela, leigo, e Maria Pia Di Dio, paulina, substituída depois por Ir. Rosana Pulga [também paulina]. Este grupo, permanente, contou com a colaboração esparsa de outros integrantes ${ }^{443}$.

Em 1982, os paulinos editam o livro $A B C$ da Bíblia, de autoria de Alberto Antoniazzi, Inês Broshuis e da paulina Rosana Pulga ${ }^{444}$. As irmãs paulinas vão, desde então, formando em Belo Horizonte um "centro bíblico", que a partir de 1990 passa a se chamar SAB - Serviço de Animação Bíblica e ganha sedes em outras cidades, como São Paulo. Todas as publicações (o semanário Bíblia-Gente, ABC da Bíblia e diversas coleções) ligadas ao centro bíblico são, entretanto, editadas pelos homens da congregação, inclusive a coleção que levaria o nome de SAB. Nota-se que as paulinas assumem funções e postos importantes, mas não publicam Bíblias nem livros de popularização da Bíblia, o que fica restrito aos homens, inclusive quando a própria autoria é de uma paulina, como no caso de Rosana Pulga ${ }^{445}$.

\footnotetext{
443 CANTARELA, Antônio Geraldo. "Tradução de Textos Bíblicos para a Linguagem Popular: A Experiência do Centro Bíblico de Belo Horizonte", op. cit., p. 117.

${ }^{444}$ Três anos depois, ele é traduzido para $E l$ ABC de la Bíblia e publicado pelas Ediciones Paulinas da Colômbia.

${ }^{445}$ As paulinas assumiam, também, o trabalho de divulgação. Na década de 1980, a irmã Tarcila Tommasi era responsável por um programa bíblico na rádio do grupo, denominado "Bíblia, Deus com a Gente".
} 
No período de produção da Edição Pastoral da Bíblia, seus tradutores Ivo Storniolo e Euclides Martins Balancin, assim como seu coordenador José Bortolini também escrevem textos para o semanário Bíblia-Gente. Assim, logo após o lançamento da Bíblia Pastoral, surge a ideia de lançar uma coleção de livros que estendessem as explicações e orientações já presentes na edição bíblica. Baseando-se nos textos do Bíblia-Gente, as Edições Paulinas criam a coleção Como Ler a Bíblia: em linguagem simplificada, com a mesma estrutura de perguntas e interação com o leitor que vimos em tantas publicações da editora, cada de um de seus pequenos volumes (grampeados, mas, diferente de Bíblia: Livro Feito em Mutirão, contavam com uma capa plástica bastante colorida e mais resistente) abordava um livro bíblico, mantendo a perspectiva da Teologia da Libertação. Todas as citações bíblicas presentes no volume da coleção eram extraídas da Bíblia Pastoral.

Por tratar-se de publicação distinta, não exigia, como a Bíblia, as autorizações eclesiásticas formais. Isso permite que os livros tratem a questão política de forma mais direta e, por vezes, mais radical que os textos presentes na Bíblia Pastoral, que, lembremos, foi alvo de polêmicas e passou por uma nova impressão, corrigida, em 1992.

A posse de um livro não implica sua leitura. Quanto mais da Bíblia, que, como afirma Roger Chartier, na tradição cristã carrega uma sacralidade especial em sua própria presença física $^{446}$, o que levanta questões sobre a motivação da compra - do status de ostentar o livro à proteção pessoal. Se o objeto livro é abordado pela historiografia em seu duplo caráter, econômico e simbólico, esta última característica é intensificada no livro religioso, e na Bíblia em especial. Por isso, a coleção Como Ler a Bíblia buscava incentivar a venda da Bíblia Pastoral e o contato com seu texto. Em diversos volumes da coleção, encontram-se sugestões de atividades para o leitor: "Leia na sua Bíblia..." e a

\footnotetext{
446 CHARTIER, Roger. "Escutar os Mortos com os Olhos". A Mão do Autor e a Mente do Editor. São
} Paulo, Editora Unesp, 2014, p. 43. 
indicação dos capítulos e versículos correspondentes ao tema tratado, numa espécie de leitura complementar/further reading. Era suposto que o leitor possuísse uma Bíblia própria, de preferência a Edição Pastoral. Nesse sentido, é possível considerar esses livros como "epitextos” à Bíblia. Nos termos de Gérard Genette, esses são os paratextos que se encontram fora do espaço do livro e que são muito usados pelos editores como forma de divulgação ${ }^{447}$. No caso da coleção Como Ler a Bíblia, trata-se ao mesmo tempo de uma divulgação de objetivos editoriais/comerciais (com vistas à venda da Bíblia), religiosos e políticos.

O primeiro volume da coleção é o único que não trata de um livro bíblico específico. História do Povo de Deus, lançado em 1990, era uma introdução geral à Bíblia. De autoria de Euclides Martins Balancin e com apresentação de José Bortolini, também havia sido publicado originalmente no folheto Bíblia-Gente. Já no primeiro capítulo “Como É que Vamos Contar a História?”, busca-se apresentar a Bíblia como uma história narrada por pessoas comuns: “A maioria dos acontecimentos conservados na Bíblia são histórias contadas pelo povo e que foram passando de geração em geração" 448 . Isso, segundo o autor, era importante pois "O povo não gosta de livros cheios de datas, documentos, explicações compridas, bibliografias. São muito complicados, usam palavras difíceis e técnicas, que provocam mais enfado do que estímulo" 449 . Com essa explicação inicial, tanto a Bíblia quanto o volume em questão eram apresentados como o oposto, uma leitura fácil, agradável e próxima à realidade do leitor. O volume privilegia a compreensão da Bíblia como uma narrativa histórica. De forma alguma secular, mas centrado antes na relação entre os próprios homens que entre estes e Deus. O início da história não se inicia com a criação:

\footnotetext{
447 GENETTE, Gérard. Paratextos Editoriais, op. cit.

${ }^{448}$ BALANCIN, Euclides Martins. História do Povo de Deus. São Paulo, Edições Paulinas, 1990. (Como Ler a Bíblia).

${ }^{449}$ Idem.
} 
Tudo começa com gente inconformada

A história do povo de Deus se inicia com grupos que não suportam qualquer tipo de opressão. Deixam a segurança da qual poderiam gozar dentro ou ao redor das cidades, chamadas de cidadesestado, onde trabalhavam como agricultores ou em outra profissão, e se tornam pastores [...].

É difícil dizer com clareza a época em que esses grupos rebeldes e avessos a sistemas opressores, isto é, quando Abraão, Isaque e Jacó começaram a se movimentar, até chegar na terra de Cana $\tilde{a}^{450}$.

De forma mais ou menos cronológica, os capítulos se sucedem até o tempo de Jesus. O livro não se encerra com o Apocalipse. Nesse, o autor vê não o fím do mundo, mas uma "literatura subversiva", que anima os oprimidos contra o opressor e "provoca resistência"451.

Há, também, capítulos temáticos. Por exemplo, sobre as estruturas econômicas ou sociais de determinado período. Ao final de cada um dos 45 capítulos, a seção "Para Refletir" lançava ao leitor perguntas que relacionassem o Brasil contemporâneo aos temas estudados na Bíblia. Por exemplo, no capítulo 41, "Grupos de Contestação", após apresentar os casos dos zelotes e dos essênios, dirige-se ao leitor:

Vocês conhecem ${ }^{452}$ na história do Brasil movimentos contestatórios à ordem vigente? Qual foi a sorte deles? Hoje, existem movimentos populares contestatórios? Na sua região existe algum? E a comunidade em que vocês vivem, é passiva ou procura agir quando os pobres e indefesos são explorados e marginalizados? Qual tipo de contestação a comunidade exerce? ${ }^{453}$

\footnotetext{
${ }^{450}$ Idem.

${ }^{451}$ No capítulo 33, "Resistência e Revolta", afirma: "No Antigo Testamento existe o livro de Daniel, que é apocalíptico. Foi escrito justamente nessa época em que começa a revolta dos Macabeus. Seu autor é um dos que aderiram à revolta [...]. Portanto, apocalíptica é uma literatura que nasce em tempo de perseguição. Ela quer provocar resistência, coragem e esperança. Não fala do fim do mundo, mas da última etapa da história, quando a 'mão forte' de Deus estará presente, ao lado dos oprimidos, para levá-los infalivelmente à vitória contra os opressores. A mensagem é transmitida através de símbolos e visões. É uma espécie de literatura subversiva que, através da fé, anima os oprimidos a enfrentar o opressor, na certeza de que Deus está do lado de quem luta pela liberdade. Um livro do Novo Testamento também pertence a esse tipo de literatura: o Apocalipse de são João, que foi escrito durante a perseguição que os cristãos sofreram por parte do império romano" (Idem).

${ }^{452}$ Por vezes o autor utiliza o singular "você". Mas o plural também é recorrente, indicando que se esperava que a leitura fosse feita de forma coletiva. ${ }^{453}$ Idem.
} 


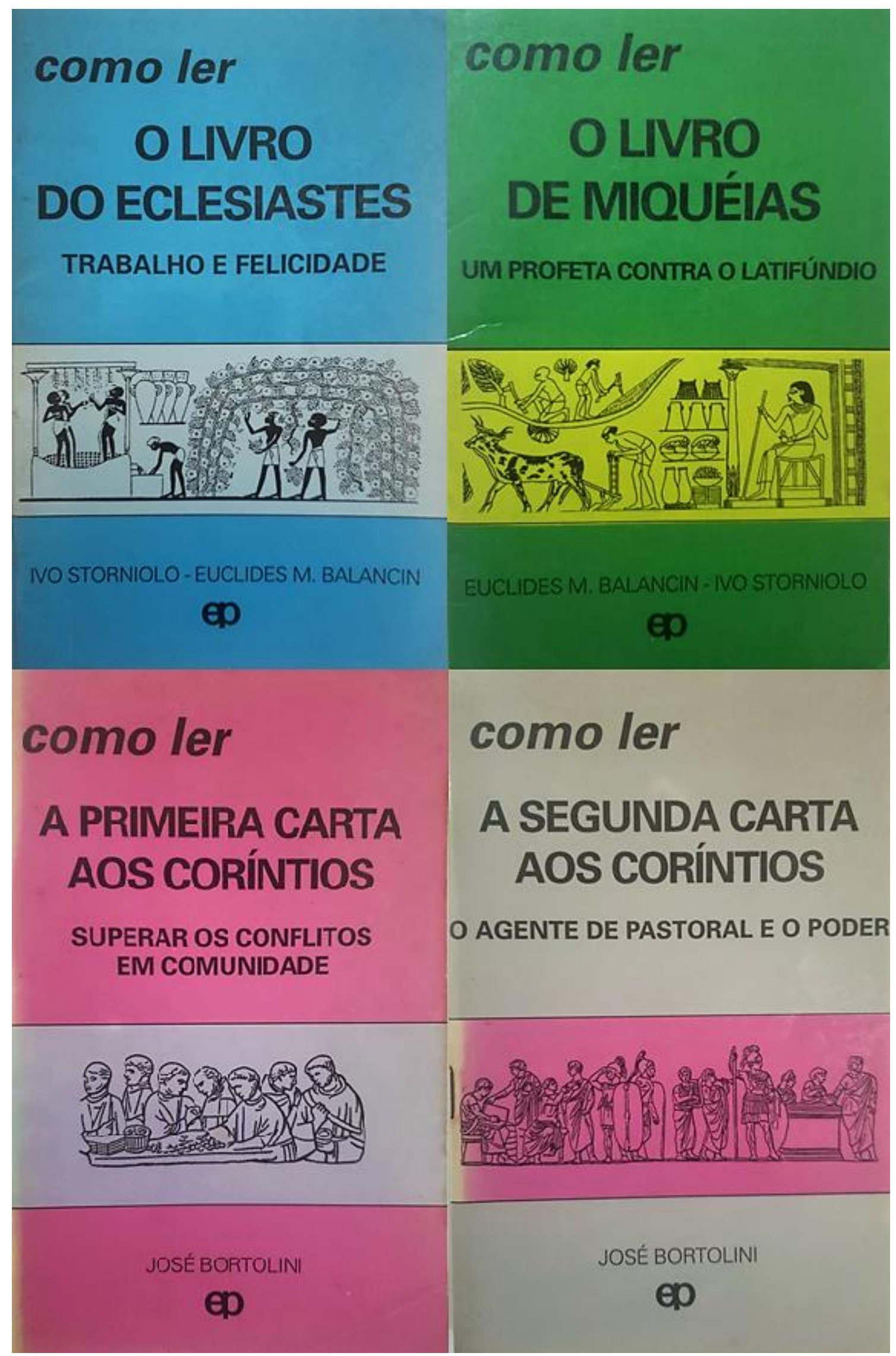

Figura 17: Algumas capas da coleção Como Ler a Bíblia 
Em outro capítulo, "Respirando Ar Estrangeiro", a questão era o imperialismo:

Por que em nossas rádios ouvimos quase só músicas cantadas em inglês? Por que muitas camisas que os jovens usam têm alguma frase escrita em inglês? Por que os noticiários da televisão dão mais espaço às notícias que acontecem nos Estados Unidos? Por que existem cursos de inglês cada vez mais numerosos? "O que é bom para os Estados Unidos é bom para o Brasil"? ${ }^{454}$

História do Povo de Deus fornece a chave de leitura para toda a coleção. Mas, em relação ao formato físico, é o volume mais destoante, com 164 páginas. Todos os outros, sobre livros bíblicos específicos, seguiam um formato bem rígido, tanto em relação ao número de páginas (entre quarenta e sessenta) e design da capa (cf. Figura 17) quanto à própria organização do texto. Todos traziam, primeiro, a mesma nota editorial sobre a coleção, que se iniciava por uma citação da Bíblia Pastoral:

\section{“COMO LER A BÍBLIA"}

“....apareceu um eunuco etíope, ministro de Candace, rainha da Etiópia... Tinha ido a Jerusalém em peregrinação, e estava voltando para casa. Ia sentado em seu carro, lendo o profeta Isaías. Então o Espírito disse a Filipe: 'Aproxime-se desse carro e o acompanhe'. Filipe correu, ouviu o eunuco ler o profeta Isaías, e perguntou: 'Você entende o que está lendo?' O eunuco respondeu: 'Como posso entender, se ninguém me explica?’ Então convidou Filipe a subir e a sentar-se junto a ele.

... Então o eunuco disse a Filipe: 'Por favor, me explique: de quem o profeta está dizendo isso? Ele fala de si mesmo, ou se refere a outra pessoa?' Então Filipe foi explicando" (At 8,27-31.34-35a) ${ }^{455}$.

Mas os editores da coleção, ao mesmo tempo que se colocavam na posição do pregador Filipe, a negavam: "Não temos a pretensão de ser como Filipe, pois a Bíblia não

\footnotetext{
${ }^{454}$ Idem.

455 A Bíblia Pastoral interpretava essa passagem dos Atos dos Apóstolos da seguinte forma, em nota de rodapé: “A conversão de um eunuco etíope mostra que a fé cristã quebra todas as barreiras, tanto raciais (o etíope é negro) como nacionais (ele é estrangeiro), tanto sociais (trata-se de escravo) como religiosas (o judaísmo não permitia que uma pessoa mutilada pertencesse à comunidade)" (Bíblia Sagrada. Edição Pastoral, op. cit., p. 1402).
} 
pertence aos estudiosos, mas ao povo. Nossa tarefa está sendo a de nos aproximar do povo, acompanhá-lo, sentar junto a ele escutando, perguntando e indicando possíveis caminhos para a compreensão".

Assim como os livros da Bíblia Pastoral, todos os volumes traziam um subtítulo que fornecia uma chave de interpretação específica para aquele livro, muitas vezes o mesmo da Bíblia Pastoral, já que seus autores/tradutores/editores, até 1994, eram também os mesmos (cf. comparação entre os títulos na Tabela 9).

O elemento distintivo dessa coleção se assemelha ao da Bíblia Pastoral. A interpretação de todos os livros se fazia com vistas à crítica à exploração e a injustiça social. Ambas foram lançadas em 1990: a questão da oposição à ditadura, que havia reunido mesmo alguns membros mais conservadores da hierarquia católica, já não existia como elemento de aglutinação ${ }^{456}$. Além do mais, as pressões de João Paulo II sobre a Teologia da Libertação já haviam afastado das questões políticas os religiosos mais moderados. Os que se mantinham nessa linha a essas alturas, portanto, foram os mais "radicais" (relativamente, isto é, radicais para a Igreja), que viam nas condições materiais estabelecidas por um "sistema injusto" os entraves para a realização do "projeto de Deus".

Para compreender melhor o caráter da coleção Como Ler a Bíblia, observemos um de seus volumes mais de perto. Como Ler o Livro de Eclesiastes: Trabalho e Felicidade, de Ivo Storniolo e Euclides Martins Balancin, foi um dos primeiros volumes publicados pela coleção, em 1990. Após a nota editorial, já comentada acima, uma introdução apresentava o significado do termo Eclesiastes e o contexto histórico da Palestina sob o governo dos Ptolomeus (século III a.C.), incluindo um diagrama e um mapa. Já nos capítulo 1, “O Que a Felicidade Não É”, e 2, “Onde Está a Felicidade?”,

\footnotetext{
${ }^{456}$ Embora, como afirmamos, a investigação sobre religiosos considerados de esquerda tenha continuado mesmo após 1988. O próprio Ivo Storniolo é citado em 1989, em um relatório elaborado pela Polícia Militar do Estado de São Paulo sobre suas críticas ao "lucro" publicadas no folheto litúrgico $O$ Domingo (Arquivo Nacional, Fundo SNI, Polícia Militar do Estado de São Paulo, Informe n. PM2-1012/2.3.4/89).
} 
vemos que o tema da felicidade não é tratado em seu sentido íntimo, individual, mas como dependente das condições sociais. O conhecimento, o prazer, e a prosperidade são "propostas burguesas de quem já tem a sobrevivência garantida" e não são acessíveis à maioria $^{457}$. Para os autores, a verdadeira felicidade, que seria demonstrada pelo Eclesiastes, estaria em "usufruir o fruto do próprio trabalho" 458 . No capítulo 3, "O Que Impede a Felicidade do Povo?" aponta-se como responsáveis a "exploração políticoeconômica" e a "dominação ideológico-religiosa"459. Ao final dessa parte, a seção “Continuando a Pensar" traz um box com perguntas:

1. Por que o trabalho se transforma em fadiga inútil?

2. Quais os agentes de exploração do trabalho do povo?

3. Os planos econômicos ajudam o povo a ser feliz no presente, ou retardam cada vez mais a sua felicidade?

4. Hoje podemos escolher nossos governantes. Costumamos escolher um sábio, ou um insensato? Como distinguir entre um e outro?

5. Os intelectuais que têm acesso aos meios de comunicação assumem a causa do povo, ou se colocam a serviço da classe dominante?

6. É verdade que um pobre não é capaz de governar ou administrar um país ou uma cidade?

7. De que forma a religião pode ser um reforço para um sistema explorador e dominador? ${ }^{460}$

Note-se que, entre as sete perguntas, três $(3,4$ e 6$)$ se relacionam diretamente às eleições e à Nova República, citando também os planos econômicos, tema do momento (o primeiro Plano Collor, por exemplo, fora instituído em março de 1990). Tem-se, ainda uma crítica à religião que serve à exploração, como vimos, uma constante da Teologia da Libertação. À pergunta do capítulo 4, "Como o Povo Pode Recuperar o Direito à Felicidade?", o autor responde que "o meio é simplesmente dizer 'Não!'”461.

\footnotetext{
${ }^{457}$ STORNIOLO, Ivo \& BALANCIN, Euclides Martins. Como Ler o Livro de Eclesiastes: Trabalho e Felicidade. São Paulo, Edições Paulinas, 1990 (Como Ler a Bíblia), p. 17.

${ }^{458}$ Idem, p. 23.

${ }^{459}$ Idem, pp. 25-27.

${ }^{460}$ Idem, p. 31.

${ }^{461}$ Idem, p. 33.
} 
1. Não ao sistema econômico explorador

2. Não ao regime político opressor

3. Não à ideologia do dominador

4. Não à religião alienante ${ }^{462}$

E conclui:

O ponto mais importante para recuperar o direito à felicidade é, portanto, a formação da consciência de classe: unir-se com os que estão na mesma situação para defender os próprios direitos e conseguir viabilizar os próprios interesses. Essa consciência, porém, não é conseguida por decreto. Ela nasce e cresce dentro de uma ação comum em que as pessoas mutuamente se compreendem e se apoiam ${ }^{463}$.

O mesmo volume sobre o Eclesiastes vê no impedimento do homem usufruir o fruto de seu trabalho um "roubo" 464 . Embora, no Brasil, costume-se reservar o termo “esquerda católica” às experiências da JUC nos anos 1960, que desembocaram em opções armadas e, mais tarde, na criação do PCdoB, pelo teor do conteúdo apresentado acima é possível afirmar que estamos diante, também, de uma esquerda católica. Ainda que não revolucionária e fundada principalmente no "basismo" ou no "associativismo" 465 , sua crítica vai além da Doutrina Social da Igreja e de termos genéricos como "pobres" e “poderosos"466. Trata-se, inegavelmente, de uma visão de mundo - mesmo que religiosa - muito influenciada pela tradição marxista.

\footnotetext{
${ }^{462}$ Idem, pp. 33-35.

${ }^{463}$ Idem, pp. 36-37.

${ }^{464}$ Idem, pp. 41-43.
}

${ }^{465}$ Sobre esse basismo, ver, entre outros, KECK, Margareth E. "A Igreja e os Movimentos Populares". PT: A Lógica da Diferença. O Partido dos Trabalhadores na Construção da Democracia Brasileira. São Paulo, Ática, 1991, pp. 61-63.

466 Tal foi a crítica realizada por José Maria de Paiva em 1985: para ele, o projeto da Igreja raramente incorporava as contradições de classe propriamente ditas, privilegiando uma divisão mais simplista, como a entre "pobres" e "poderosos", o que, para Paiva, cairia inevitavelmente em uma visão mais conciliatória (do "povo") que revolucionária (PAIVA, José Maria de. A Imagem que a Igreja Tem da Realidade Brasileira. Um Estudo Através das Comunidades Eclesiais de Base - CEBs. Tese de Doutorado em Educação, Universidade Estadual de Campinas, 1985). De fato, essa poderia ser a visão da Igreja progressista mais moderada. A conciliação foi também a política hegemônica do PT - formado em parte pelos movimentos católicos - sobretudo depois de sua chegada ao poder. Mas, a nosso ver, não era a dos editores da Bíblia Pastoral, tampouco dos autores da coleção Como Ler a Bíblia, que insistiam na categoria de "classe" e na exploração inerente ao sistema econômico e político brasileiro, ao qual só restava a transformação. 
Outro volume dos mesmos autores, por exemplo, já no título explicitava seu caráter político: Como Ler o Livro de Miqueias: Um Profeta Contra o Latifúndio. Não se trata de um livro muito popular da Bíblia, mas ele servia de mote para propor questões como "Todo latifúndio é um roubo. Por que, do que e de quem?" e "Por que é necessário que se faça urgentemente uma reforma agrária em nosso país?”467.

Em Como Ler a Carta aos Coríntios: Superar os Conflitos em Comunidade (o livro reforçava a questão da vida e leitura comunitárias), de José Bortolini, a já comentada crítica à religião alienante atingia seu ápice, chegando a questionar a própria eucaristia, fundamental dentro do catolicismo. Se ela não tivesse em vista a transformação, era uma forma de idolatria. Em 1 Coríntios 11, depois de uma exposição de Jesus sobre a relação entre o pão e o vinho com seu corpo e sangue, o autor da epístola prega que "[...] todo aquele que comer do pão ou beber do cálice do Senhor indignamente, será réu do corpo do Senhor. Portanto, cada um examine a si mesmo antes de comer deste pão e beber deste cálice" ${ }^{\text {"468 }}$. Partindo desse trecho e dos versículos que o antecedem (especialmente 1Cor 11:20-22) ${ }^{469}$, Bortolini afirma que:

Podemos desconfiar das celebrações eucarísticas que não levam à transformação pessoal, comunitária e social. Os coríntios haviam perdido de vista essa perspectiva transformada. Paulo lhes garante que já não estão "comendo a Ceia do Senhor". E nós podemos acrescentar: eles transformaram a eucaristia numa espécie de idolatria semelhante à idolatra da sociedade estabelecida, que mantém privilégios e discriminações. É por isso que, em vez de ser fonte de vida, ela se torna fonte de condenação $0^{470}$.

A figura do agente de pastoral também era recorrentemente tratada pela coleção. Por exemplo, em Como Ler a Primeira Carta aos Tessalonicenses: Fé, Amor, Esperança,

\footnotetext{
467 BALANCIN, Euclides Martins \& STORNIOLO, Ivo. Como Ler o Livro de Miqueias: Um Profeta Contra o Latifúndio. São Paulo, Edições Paulinas, 1990 (Como Ler a Bíblia), pp. 22, 29.

4681 Coríntios 11:27-28. Bíblia Sagrada. Edição Pastoral, op. cit., p. 1472.

${ }^{469} \mathrm{Na}$ mesma tradução: "De fato, quando se reúnem, o que vocês fazem não é comer a Ceia do Senhor, porque cada um se apressa a comer sua própria ceia. E, enquanto um passa fome, outro fica embriagado. Será que vocês não têm suas casas onde comer e beber? Ou desprezam a Igreja de Deus e querem envergonhar aqueles que nada têm?” (1 Coríntios 11:20-22. Bíblia Sagrada. Edição Pastoral, op. cit., p. 1472).

${ }^{470}$ BORTOLINI, José. Como Ler a Primeira Carta aos Coríntios: Superar os Conflitos em Comunidade. São Paulo, Edições Paulinas, 1992 (Como Ler a Bíblia), p. 57.
} 
José Bortolini trata Paulo como o modelo para o agente ${ }^{471}$. Já outro volume do mesmo autor, sobre a Segunda Carta aos Coríntios, era inteiro dedicado à questão, com o subtítulo O Agente de Pastoral e o Poder ${ }^{472}$.

Note-se que os primeiros volumes publicados não se referiam, necessariamente, aos livros mais populares da Bíblia (como os evangelhos, por exemplo). Mais do que apresentar-se como um curso ou um guia bíblico, a coleção partia das escrituras cristãs para abordar questões sociais. Por isso, eram escolhidos primeiro aqueles que fornecessem mais material para essas discussões. O último volume sobre um evangelho, o de João, é lançado apenas em 1994. No mesmo ano sai um especial, Como Ler os Evangelhos: Para Entender o que Jesus Fazia e Dizia, de autoria de Félix Moracho. Em 2001, outro volume especial seria Introdução a Paulo e suas Cartas, de José Bortolini.

Na Tabela 9, comparamos os subtítulos atribuídos aos livros bíblicos pela Edição Pastoral da Bíblia e pela coleção Como Ler a Bíblia. Nota-se que os que são semelhantes ou próximos foram escritos por Ivo Storniolo, Euclides Martins Balancin ou José Bortolini, em especial os volumes anteriores a 1995. Isso ocorre porque, a partir de 1995, a coleção começa a mudar, com a entrada de novos autores ${ }^{473}$. Bortolini e Storniolo lançariam apenas mais alguns volumes; Balancin, nenhum. Nota-se que, a partir de então, os títulos são mais estritamente religiosos e menos políticos. A coleção já não se vinculava aos tradutores da Bíblia Pastoral, mas a um número maior de estudiosos. A editora consegue completar todos os volumes sobre os livros bíblicos apenas em 2004. Apesar desse intervalo 1995-2004 ultrapassar o recorte principal de nossa pesquisa,

\footnotetext{
${ }^{471}$ BORTOLINI, José. Como Ler a Primeira Carta aos Tessalonicenses: Fé, Amor, Esperança. São Paulo, Edições Paulinas, 1991 (Como Ler a Bíblia), pp. 39-45.

472 BORTOLINI, José. Como Ler a Segunda Carta aos Coríntios: O Agente de Pastoral e o Poder. São Paulo, Edições Paulinas, 1992. (Como Ler a Bíblia).

${ }^{473}$ Antes, tivera a participação de Carlos Mesters e Marc Girard, que participavam, entretanto, do mesmo projeto e seus livros mantinham as mesmas perspectivas dos outros autores. A única diferença a se apontar era o maior número de páginas dos volumes de Girard, contando com textos mais longos e reflexões mais aprofundadas.
} 
reproduzimos também os títulos produzidos nesse tempo nas tabelas 7 e 8 , a fim de oferecer uma compreensão melhor da coleção e, justamente, perceber a transformação pela qual ela e a editora passam a partir de 1995 (quando, lembre-se, encerra-se definitivamente a marca Edições Paulinas).

Nos volumes de autoria de outros autores que não os originais, o caráter fortemente político vai sendo amenizado. De Um Profeta Contra o Latifúndio, passa-se a ter títulos como Como Ler os Livros de Esdras e Neemias: A Fé em Deus Vem Antes da Política (este último de Alfredo dos Santos Oliva, 1999).

Em 2014, é lançada a Nova Bíblia Pastoral, com outra tradução, realizada por outros tradutores, com outras introduções e notas, elaboradas por outros autores - muitos dos quais haviam participado da nova fase da coleção Como Ler a Bíblia a partir de 1995, como Pedro Lima Vasconcellos, Paulo Bazaglia, Rafael Rodrigues da Silva e Shigeyuki Nakanose. Apenas o revisor literário, José Dias Goulart, se mantém o mesmo nas duas edições, além de Carlos Mesters, que escreve as introduções e notas de 2014. Embora não houvesse participado da tradução original, Mesters, como vimos, foi um dos organizadores dos Círculos Bíblicos e autor principal da coleção Por Trás das Palavras, na década de 1980.

Os subtítulos, por exemplo, que eram uma característica importante da edição de 1990, foram em sua maioria modificados em 2014, mas mantêm algumas das categorias da Teologia da Libertação ${ }^{474}$. Além disso, o próprio sumário não os reproduz, limitandose aos nomes dos livros, o que contribui para que o aspecto geral da nova edição seja mais "neutro", isto é, com menos intervenções editoriais. O que, na realidade, não representa uma diminuição da mediação, mas uma mediação em outro sentido, conscientemente contida. Contenção que ocorria, como vimos no caso da coleção Como Ler a Bíblia, desde o período imediatamente posterior ao encerramento da marca Edições Paulinas.

\footnotetext{
${ }^{474}$ Por exemplo, Êxodo: Deus é presença libertadora junto aos oprimidos; Miqueias: Contra as injustiças sociais; Lucas: Jesus, o messias dos pobres. (Nova Bíblia Pastoral. São Paulo, Paulus, 2014).
} 


\section{Tabela 8. Coleção Como Ler a Bíblia}

(A partir de 1993, os volumes da coleção são publicados sob a marca Paulus).

\begin{tabular}{|c|c|c|}
\hline Ano & Título & Autor \\
\hline 1990 & História do Povo de Deus & $\begin{array}{c}\text { Euclides Martins } \\
\text { Balancin }\end{array}$ \\
\hline 1990 & $\begin{array}{l}\text { Como Ler o Livro do Eclesiastes: } \\
\text { Trabalho e Felicidade }\end{array}$ & $\begin{array}{c}\text { Ivo Storniolo; Euclides } \\
\text { Martins Balancin }\end{array}$ \\
\hline 1990 & $\begin{array}{l}\text { Como Ler o Livro do Exxodo: } \\
\text { O Caminho para a Liberdade }\end{array}$ & $\begin{array}{c}\text { Euclides Martins } \\
\text { Balancin; Ivo Storniolo }\end{array}$ \\
\hline 1990 & $\begin{array}{l}\text { Como Ler o Livro de Miqueias: } \\
\text { Um Profeta Contra o Latifúndio }\end{array}$ & $\begin{array}{c}\text { Euclides Martins } \\
\text { Balancin; Ivo Storniolo }\end{array}$ \\
\hline 1991 & $\begin{array}{l}\text { Como Ler o Evangelho de Mateus: } \\
\text { O Caminho da Justiça }\end{array}$ & Ivo Storniolo \\
\hline 1991 & $\begin{array}{l}\text { Como Ler o Livro do Gênesis: } \\
\text { Origem da Vida e da História }\end{array}$ & $\begin{array}{c}\text { Ivo Storniolo; Euclides } \\
\text { Martins Balancin }\end{array}$ \\
\hline 1991 & $\begin{array}{c}\text { Como Ler o Livro de Amós: } \\
\text { A Denúncia da Injustiça Social }\end{array}$ & $\begin{array}{c}\text { Euclides Martins } \\
\text { Balancin; Ivo Storniolo }\end{array}$ \\
\hline 1991 & $\begin{array}{l}\text { Como Ler o Livro de Jonas: } \\
\text { Deus Não Conhece Fronteiras }\end{array}$ & $\begin{array}{l}\text { Euclides Martins } \\
\text { Balancin; Ivo Storniolo }\end{array}$ \\
\hline 1991 & $\begin{array}{l}\text { Como Ler o Livro de Habacuc: } \\
\text { A Teimosia do Justo }\end{array}$ & $\begin{array}{c}\text { Euclides Martins } \\
\text { Balancin; Ivo Storniolo }\end{array}$ \\
\hline 1991 & $\begin{array}{l}\text { Como Ler o Livro de Rute: } \\
\text { Pão, Família, Terra }\end{array}$ & Carlos Mesters \\
\hline 1991 & $\begin{array}{c}\text { Como Ler a Primeira Carta aos Tessalonicenses: } \\
\text { Fé, Amor, Esperança }\end{array}$ & José Bortolini \\
\hline 1991 & $\begin{array}{c}\text { Como Ler os Livros de Samuel: } \\
\text { A Função da Autoridade }\end{array}$ & $\begin{array}{c}\text { Ivo Storniolo; Euclides } \\
\text { Martins Balancin }\end{array}$ \\
\hline 1991 & $\begin{array}{c}\text { Como Ler a Segunda Carta aos Tessalonicenses: } \\
\text { Esperar É Resistir }\end{array}$ & José Bortolini \\
\hline 1991 & $\begin{array}{c}\text { Como Ler a Carta aos Filipenses: } \\
\text { O Evangelho Encarnado }\end{array}$ & José Bortolini \\
\hline
\end{tabular}




\begin{tabular}{|c|c|c|}
\hline 1991 & $\begin{array}{c}\text { Como Ler o Cântico dos Cânticos: } \\
\text { O Amor é uma Faísca de Deus }\end{array}$ & $\begin{array}{c}\text { Ivo Storniolo; Euclides } \\
\text { Martins Balancin }\end{array}$ \\
\hline 1991 & $\begin{array}{c}\text { Como Ler a Carta aos Gálatas: } \\
\text { Evangelho É Liberdade }\end{array}$ & José Bortolini \\
\hline 1991 & $\begin{array}{l}\text { Como Ler a Carta aos Colossenses: } \\
\text { Reconstruir a Esperança em Cristo }\end{array}$ & José Bortolini \\
\hline 1991 & $\begin{array}{c}\text { Como Ler o Evangelho de Marcos: } \\
\text { Quem É Jesus? }\end{array}$ & $\begin{array}{c}\text { Euclides Martins } \\
\text { Balancin }\end{array}$ \\
\hline 1991 & $\begin{array}{l}\text { Como Ler o Livro de Sofonias: } \\
\text { A Esperança Vem dos Pobres }\end{array}$ & $\begin{array}{c}\text { Euclides Martins } \\
\text { Balancin; Ivo Storniolo }\end{array}$ \\
\hline 1991 & $\begin{array}{l}\text { Como Ler o Livro dos Provérbios: } \\
\text { A Sabedoria do Povo }\end{array}$ & Ivo Storniolo \\
\hline 1992 & $\begin{array}{c}\text { Como Ler o Livro de Ageu: } \\
\text { É Urgente Reconstruir }\end{array}$ & Marc Girard \\
\hline 1992 & $\begin{array}{l}\text { Como Ler o Livro dos Salmos: } \\
\text { Espelho da Vida do Povo }\end{array}$ & Marc Girard \\
\hline 1992 & $\begin{array}{l}\text { Como Ler o Livro do Deuteronômio: } \\
\text { Escolher a Vida ou a Morte }\end{array}$ & Ivo Storniolo \\
\hline 1992 & $\begin{array}{c}\text { Como Ler a Primeira Carta aos Coríntios: } \\
\text { Superar os Conflitos em Comunidade }\end{array}$ & José Bortolini \\
\hline 1992 & $\begin{array}{c}\text { Como Ler o Livro de Josué: } \\
\text { Terra }=\text { Vida } \\
\text { Dom de Deus e Conquista do Povo }\end{array}$ & Ivo Storniolo \\
\hline 1992 & $\begin{array}{c}\text { Como Ler a Segunda Carta aos Coríntios: } \\
\text { O Agente de Pastoral e o Poder }\end{array}$ & José Bortolini \\
\hline 1992 & $\begin{array}{c}\text { Como Ler o Livro de Jó: } \\
\text { O Desafio da Verdadeira Religião }\end{array}$ & Ivo Storniolo \\
\hline 1992 & $\begin{array}{l}\text { Como Ler o Livro dos Juízes: } \\
\text { Aprendendo a Ler a História }\end{array}$ & Ivo Storniolo \\
\hline 1992 & $\begin{array}{l}\text { Como Ler os Livros dos Reis: } \\
\text { Da Glória à Ruína }\end{array}$ & Ivo Storniolo \\
\hline 1992 & $\begin{array}{c}\text { Como Ler o Evangelho de Lucas: } \\
\text { Os Pobres Constroem a Nova História }\end{array}$ & Ivo Storniolo \\
\hline
\end{tabular}




\begin{tabular}{|c|c|c|}
\hline 1993 & $\begin{array}{l}\text { Como Ler os Atos dos Apóstolos: } \\
\text { o Caminho do Evangelho }\end{array}$ & Ivo Storniolo \\
\hline 1993 & $\begin{array}{l}\text { Como Ler o Livro da Sabedoria: } \\
\text { A Sabedoria de Israel É o Senso da Justiça }\end{array}$ & Ivo Storniolo \\
\hline 1994 & $\begin{array}{l}\text { Como Ler o Livro de Judite: } \\
\text { A Viúva que Salvou o seu Povo }\end{array}$ & Ivo Storniolo \\
\hline 1994 & $\begin{array}{l}\text { Como Ler o Livro do Eclesiástico: } \\
\text { A Identidade de um Povo }\end{array}$ & Ivo Storniolo \\
\hline 1994 & $\begin{array}{l}\text { Como Ler o Livro de Tobias: } \\
\text { A Família Gera Vida }\end{array}$ & $\begin{array}{c}\text { Ivo Storniolo; José } \\
\text { Bortolini }\end{array}$ \\
\hline 1994 & $\begin{array}{c}\text { Como Ler o Evangelho de João: } \\
\text { O Caminho da Vida }\end{array}$ & José Bortolini \\
\hline 1994 & $\begin{array}{l}\text { Como Ler os Evangelhos: } \\
\text { Para Entender o que Jesus Fazia e Dizia }\end{array}$ & Félix Moracho \\
\hline 1994 & $\begin{array}{l}\text { Como Ler o Apocalipse: } \\
\text { Resistir e Denunciar }\end{array}$ & José Bortolini \\
\hline 1995 & $\begin{array}{l}\text { Como Ler a Carta a Filemon: } \\
\text { Em Cristo Todos São Irmãos }\end{array}$ & José Bortolini \\
\hline 1995 & $\begin{array}{l}\text { Como Ler a Carta de Tiago: } \\
\text { A Fé e a Prática do Evangelho }\end{array}$ & Ivo Storniolo \\
\hline 1995 & $\begin{array}{l}\text { Como Ler o Livro do Levítico: } \\
\text { Formação de um Povo Santo }\end{array}$ & Ivo Storniolo \\
\hline 1995 & $\begin{array}{l}\text { Como Ler o Livro de Ester: } \\
\text { O Poder a Serviço da Justiça }\end{array}$ & Ivo Storniolo \\
\hline 1995 & $\begin{array}{c}\text { Como Ler o Livro de Oséias: } \\
\text { Reconstruir a Casa }\end{array}$ & $\begin{array}{c}\text { Enilda de Paula Pedro; } \\
\text { Shigeyuki Nakanose }\end{array}$ \\
\hline 1996 & $\begin{array}{l}\text { Como Ler o Livro de Malaquias: } \\
\text { Defender a Tradição ou a Vida? }\end{array}$ & $\begin{array}{l}\text { Shigeyuki Nakanose; } \\
\text { Enilda de Paula Pedro }\end{array}$ \\
\hline 1996 & $\begin{array}{c}\text { Como Ler o Livro dos Números: } \\
\text { A Pedagogia do Deserto }\end{array}$ & Ivo Storniolo \\
\hline 1997 & $\begin{array}{l}\text { Como Ler o Livro de Daniel: } \\
\text { Reino de Deus e Imperialismo }\end{array}$ & Ivo Storniolo \\
\hline 1997 & Como Ler a Carta aos Romanos: & José Bortolini \\
\hline
\end{tabular}




\begin{tabular}{|c|c|c|}
\hline & O Evangelho é a Força de Deus que Salva & \\
\hline 1997 & $\begin{array}{l}\text { Como Ler a Segunda Carta a Timóteo: } \\
\text { Retratos do Pastor e do Mártir Cristão }\end{array}$ & José Bortolini \\
\hline 1998 & $\begin{array}{l}\text { Como Ler a Carta a Tito: } \\
\text { O Cotidiano da Fé }\end{array}$ & José Bortolini \\
\hline 1998 & $\begin{array}{l}\text { Como Ler o Livro de Naum: } \\
\text { A História Pertence a Javé }\end{array}$ & $\begin{array}{l}\text { Luiz Alexandre Solano } \\
\text { Rossi }\end{array}$ \\
\hline 1998 & $\begin{array}{c}\text { Como Ler o Livro de Abdias: } \\
\text { Profeta da Solidariedade }\end{array}$ & $\begin{array}{l}\text { Luiz Alexandre Solano } \\
\text { Rossi }\end{array}$ \\
\hline 1998 & $\begin{array}{c}\text { Como Ler o Livro de Joel: } \\
\text { Profecia em Tempos de Crise }\end{array}$ & $\begin{array}{l}\text { Luiz Alexandre Solano } \\
\text { Rossi }\end{array}$ \\
\hline 1999 & $\begin{array}{l}\text { Como Ler o Livro das Lamentações: } \\
\text { Não Existe Sofrimento Estranho }\end{array}$ & $\begin{array}{l}\text { Luiz Alexandre Solano } \\
\text { Rossi }\end{array}$ \\
\hline 1999 & $\begin{array}{l}\text { Como Ler os Livros de Esdras e Neemias: } \\
\text { A Fé em Deus Vem Antes da Política }\end{array}$ & $\begin{array}{l}\text { Alfredo dos Santos } \\
\text { Oliva }\end{array}$ \\
\hline 1999 & $\begin{array}{l}\text { Como Ler o Primeiro Isaías (1-39): } \\
\text { Confiar em Javé, o Santo de Israel }\end{array}$ & $\begin{array}{l}\text { Shigeyuki Nakanose; } \\
\text { Enilda de Paula Pedro }\end{array}$ \\
\hline 2000 & $\begin{array}{l}\text { Como Ler o Livro de Zacarias: } \\
\text { O Profeta da Reconstrução }\end{array}$ & $\begin{array}{l}\text { Luiz Alexandre Solano } \\
\text { Rossi }\end{array}$ \\
\hline 2001 & $\begin{array}{c}\text { Como Ler as Cartas de João: } \\
\text { Quem Ama Nasceu de Deus e Conhece a Deus }\end{array}$ & $\begin{array}{c}\text { José Bortolini; Paulo } \\
\text { Bazaglia }\end{array}$ \\
\hline 2001 & $\begin{array}{c}\text { Como Ler a Primeira Carta a Timóteo: } \\
\text { Organizar a Pastoral nos Conflitos }\end{array}$ & José Bortolini \\
\hline 2001 & $\begin{array}{l}\text { Como Ler a Carta de Judas: } \\
\text { Coragem para Lutar pela Fé }\end{array}$ & José Bortolini \\
\hline 2001 & $\begin{array}{l}\text { Como Ler a Carta aos Efésios: } \\
\text { O Universo Inteiro Reunido em Cristo }\end{array}$ & José Bortolini \\
\hline 2001 & Introdução a Paulo e suas Cartas & José Bortolini \\
\hline 2001 & $\begin{array}{l}\text { Como Ler o Livro de Ezequiel: } \\
\text { O Profeta da Esperança }\end{array}$ & $\begin{array}{c}\text { Luiz Alexandre Solano } \\
\text { Rossi }\end{array}$ \\
\hline 2002 & Como Ler as Cartas de Pedro: & $\begin{array}{l}\text { Paulo Augusto de } \\
\text { Souza Nogueira }\end{array}$ \\
\hline
\end{tabular}




\begin{tabular}{|c|c|c|}
\hline & O Evangelho dos Sem-Teto ${ }^{475}$ & \\
\hline 2002 & $\begin{array}{l}\text { Como Ler os Livros das Crônicas: } \\
\text { Quem Conta um Conto Aumenta um Ponto }\end{array}$ & $\begin{array}{l}\text { Alfredo dos Santos } \\
\text { Oliva }\end{array}$ \\
\hline 2002 & $\begin{array}{c}\text { Como Ler o Livro de Jeremias: } \\
\text { Profecia a Serviço do Povo }\end{array}$ & $\begin{array}{c}\text { Luiz Alexandre Solano } \\
\text { Rossi }\end{array}$ \\
\hline 2003 & $\begin{array}{l}\text { Como Ler o Livro de Baruc: } \\
\text { Releituras do Exílio. Criatividade na Crise }\end{array}$ & $\begin{array}{l}\text { Rafael Rodrigues da } \\
\text { Silva }\end{array}$ \\
\hline 2003 & $\begin{array}{c}\text { Como Ler a Carta aos Hebreus: } \\
\text { Um Sacerdote Fiel para um Povo a Caminho }\end{array}$ & $\begin{array}{l}\text { Pedro Lima } \\
\text { Vasconcellos }\end{array}$ \\
\hline 2004 & $\begin{array}{c}\text { Como Ler o Segundo Isaías (40-55): } \\
\text { Da Semente Esmagada Brota Nova Vida }\end{array}$ & $\begin{array}{l}\text { Shigeyuki Nakanose; } \\
\text { Enilda de Paula Pedro }\end{array}$ \\
\hline 2004 & $\begin{array}{c}\text { Como Ler o Terceiro Isaías (56-66): } \\
\text { Novo Céu e Nova Terra }\end{array}$ & $\begin{array}{c}\text { Shigeyuki Nakanose; } \\
\text { Enilda de Paula Pedro; } \\
\text { Cecília Toseli }\end{array}$ \\
\hline 2004 & $\begin{array}{c}\text { Como Ler os Livros dos Macabeus: } \\
\text { Memórias da Guerra. O Livro das Batalhas e O } \\
\text { Livro dos Testemunhos }\end{array}$ & $\begin{array}{l}\text { Pedro Lima } \\
\text { Vasconcellos; Rafael } \\
\text { Rodrigues da Silva }\end{array}$ \\
\hline
\end{tabular}

475 Trata-se de uma reedição do volume publicado na coleção Por Trás das Palavras em 1993 (cf. Tabela 7). 
Tabela 9. Subtítulos atribuídos aos livros bíblicos:

Bíblia Pastoral e Coleção Como Ler a Bíblia

(Os títulos com * referem-se a volumes de Ivo Storniolo, Euclides Martins Balancin ou José Bortolini).

\begin{tabular}{|c|c|c|}
\hline Livro & Bíblia Sagrada: Edição Pastoral & Como Ler a Bíblia \\
\hline \multicolumn{3}{|c|}{ Antigo Testamento } \\
\hline Gênesis & Origem da vida e da história & Origem da vida e da história* \\
\hline$\hat{\text { Exxodo }}$ & Deus liberta e forma seu povo & O caminho para a liberdade* \\
\hline Levítico & Formação de um povo santo & Formação de um povo santo* \\
\hline Números & A caminho da terra prometida & A pedagogia do deserto* \\
\hline Deuteronômio & Projeto de uma nova sociedade & Escolher a vida ou a morte* \\
\hline Josué & A terra é dom e conquista & $\begin{array}{l}\text { Terra = vida: dom de Deus e } \\
\text { conquista do povo* }\end{array}$ \\
\hline Juízes & A dinâmica do processo histórico & Aprendendo a ler a história* \\
\hline Rute & $\begin{array}{l}\text { A luta dos pobres pelos seus } \\
\text { direitos }\end{array}$ & Pão, família, terra \\
\hline $1^{\circ}$ e $2^{\circ}$ Samuel & A função da autoridade & A função da autoridade* \\
\hline $1^{\circ}$ e $2^{\circ}$ Reis & Da glória à ruína & Da glória à ruína* \\
\hline $1^{\circ}$ e $2^{\circ}$ Crônicas & Revisão da história do povo & $\begin{array}{l}\text { Quem conta um conto aumenta } \\
\text { um ponto }\end{array}$ \\
\hline $\begin{array}{l}\text { Esdras e } \\
\text { Neemias }\end{array}$ & Organização da Comunidade & $\begin{array}{l}\text { A fé em Deus vem antes da } \\
\text { política }\end{array}$ \\
\hline Tobias & O justo é semente de esperança & A família gera vida* \\
\hline Judite & A invencível força dos fracos & $\begin{array}{l}\text { A viúva que salvou o seu } \\
\text { povo* }\end{array}$ \\
\hline Ester & O poder a serviço da justiça & O poder a serviço da justiça* \\
\hline 1 Macabeus & Resistir em nome da fé & $\begin{array}{l}\text { Memórias da Guerra. O Livro } \\
\text { das Batalhas }\end{array}$ \\
\hline 2 Macabeus & A fé leva ao heroísmo & $\begin{array}{l}\text { Memórias da Guerra. O Livro } \\
\text { dos Testemunhos }\end{array}$ \\
\hline Jó & A verdadeira religião & $\begin{array}{l}\text { O desafio da verdadeira } \\
\text { religião* }\end{array}$ \\
\hline
\end{tabular}




\begin{tabular}{|c|c|c|}
\hline Salmos & A oração do povo de Deus & Espelho da vida do povo \\
\hline Provérbios & $\begin{array}{l}\text { Deus fala através da experiência } \\
\text { do povo }\end{array}$ & A sabedoria do povo* \\
\hline Eclesiastes & Felicidade é viver o presente & Trabalho e felicidade* \\
\hline $\begin{array}{l}\text { Cântico dos } \\
\text { Cânticos }\end{array}$ & O mistério do amor & O amor é uma faísca de Deus* \\
\hline Sabedoria & A justiça é imortal & $\begin{array}{l}\text { A sabedoria de Israel é o senso } \\
\text { da justiça* }\end{array}$ \\
\hline Eclesiástico & $\begin{array}{l}\text { A preservação da identidade do } \\
\text { povo }\end{array}$ & A identidade de um povo* \\
\hline Isaías & A santidade de Deus & $\begin{array}{l}\text { Confiar em Javé, o santo de } \\
\text { Israel; Da semente esmagada } \\
\text { brota nova vida; Novo Céu e } \\
\text { nova Terra }\end{array}$ \\
\hline Jeremias & Uma nova aliança & Profecia a serviço do povo \\
\hline Lamentações & Um povo humilhado & Não existe sofrimento estranho \\
\hline Baruc & Arrependimento e conversão & $\begin{array}{l}\text { Releituras do exílio: } \\
\text { criatividade na crise }\end{array}$ \\
\hline Ezequiel & Um coração novo & O profeta da esperança \\
\hline Daniel & O triunfo do Reino de Deus & $\begin{array}{l}\text { Reino de Deus e } \\
\text { Imperialismo* }\end{array}$ \\
\hline Oséias & Deus é amor fiel & Reconstruir a casa \\
\hline Joel & O dia do julgamento & Profecia em tempos de crise \\
\hline Amós & Contra a injustiça social & A denúncia da injustiça social* \\
\hline Abdias & Contra a falta de solidariedade & Profeta da solidariedade \\
\hline Jonas & Deus não conhece fronteiras & Deus não conhece fronteiras* \\
\hline Miqueias & O direito dos pobres & $\begin{array}{l}\text { Um profeta contra o } \\
\text { latifúndio* }\end{array}$ \\
\hline Naum & A ruína do opressor & A história pertence a Javé \\
\hline Habacuc & O justo viverá por sua fidelidade & A teimosia do justo* \\
\hline Sofonias & Os pobres da terra & A esperança vem dos pobres* \\
\hline Ageu & Reestruturar o povo de Deus & É urgente reconstruir \\
\hline Zacarias & Deus continua presente & O profeta da reconstrução \\
\hline
\end{tabular}




\begin{tabular}{|c|c|c|}
\hline Malaquias & Uma religião sincera & Defender a tradição ou a vida? \\
\hline \multicolumn{3}{|c|}{ Novo Testamento } \\
\hline $\begin{array}{l}\text { Evangelho de } \\
\text { Mateus }\end{array}$ & Jesus, o mestre da justiça & O caminho da justiça* \\
\hline $\begin{array}{l}\text { Evangelho de } \\
\text { Marcos }\end{array}$ & Quem é Jesus? & Quem é Jesus?* \\
\hline $\begin{array}{l}\text { Evangelho de } \\
\text { Lucas }\end{array}$ & $\begin{array}{l}\text { Com Jesus nasce uma nova } \\
\text { história }\end{array}$ & $\begin{array}{l}\text { Os pobres constroem uma nova } \\
\text { história* }\end{array}$ \\
\hline $\begin{array}{l}\text { Evangelho de } \\
\text { João }\end{array}$ & O caminho da vida & O caminho da vida* \\
\hline $\begin{array}{l}\text { Atos dos } \\
\text { Apóstolos }\end{array}$ & O caminho da missão & O caminho do Evangelho* \\
\hline Romanos & A salvação vem pela fé & $\begin{array}{l}\text { O Evangelho é a força de Deus } \\
\text { que salva* }\end{array}$ \\
\hline 1 Coríntios & $\begin{array}{l}\text { Como superar os conflitos em } \\
\text { comunidade }\end{array}$ & $\begin{array}{l}\text { Superar os conflitos em } \\
\text { comunidade* }\end{array}$ \\
\hline 2 Coríntios & A força se manifesta na fraqueza & $\begin{array}{l}\text { O agente de pastoral e o } \\
\text { poder* }\end{array}$ \\
\hline Gálatas & Da escravidão para a liberdade & Evangelho é liberdade* \\
\hline Efésios & Vida plena em Cristo & $\begin{array}{l}\text { O universo inteiro reunido em } \\
\text { Cristo* }\end{array}$ \\
\hline Filipenses & O verdadeiro Evangelho & O Evangelho encarnado* \\
\hline Colossenses & Cristo, imagem do Deus invisível & $\begin{array}{l}\text { Reconstruir a esperança em } \\
\text { Cristo* }\end{array}$ \\
\hline $\begin{array}{l}1 \\
\text { Tessalonicenses }\end{array}$ & Fé, amor e esperança & Fé, amor, esperança* \\
\hline $\begin{array}{l}2 \\
\text { Tessalonicenses }\end{array}$ & $\begin{array}{l}\text { Resistência em meio aos } \\
\text { conflitos }\end{array}$ & Esperar é resistir* \\
\hline 1 Timóteo & Apelo ao discernimento & $\begin{array}{l}\text { Organizar a pastoral nos } \\
\text { conflitos* }\end{array}$ \\
\hline 2 Timóteo & Combater o bom combate & $\begin{array}{l}\text { Retratos do pastor e do mártir } \\
\text { cristão* }\end{array}$ \\
\hline Tito & Expressar a fé na vida & O cotidiano da fé* \\
\hline
\end{tabular}




\begin{tabular}{|l|l|l|}
\hline Filemon & Em Cristo todos são irmãos & Em Cristo todos são irmãos* \\
\hline Hebreus & $\begin{array}{l}\text { Cristo é o único sacerdote } \\
\text { verdadeiro }\end{array}$ & $\begin{array}{l}\text { Um sacerdote fiel para um } \\
\text { povo a caminho }\end{array}$ \\
\hline Tiago & A fé é prática da justiça & A fé e a prática do Evangelho* \\
\hline 1 Pedro & Um lar para quem não tem casa & O Evangelho dos sem-teto \\
\hline 2 Pedro & Perseverar na esperança & O Evangelho dos sem-teto \\
\hline 1 João & O dinamismo da fé é o amor & $\begin{array}{l}\text { Quem ama nasceu de Deus e } \\
\text { conhece a Deus* }\end{array}$ \\
\hline 2 João & Viver na verdade & $\begin{array}{l}\text { Quem ama nasceu de Deus e } \\
\text { conhece a Deus* }\end{array}$ \\
\hline 3 João & Cooperadores da verdade & $\begin{array}{l}\text { Quem ama nasceu de Deus e } \\
\text { conhece a Deus* }\end{array}$ \\
\hline Judas & Não desanimar na fé & Coragem para lutar pela fé* \\
\hline Apocalipse & A coragem do testemunho & Resistir e denunciar* \\
\hline
\end{tabular}




\section{Considerações Finais}

É possível considerar que o que permitiu às Edições Paulinas uma posição privilegiada no mercado editorial, sobretudo na década de 1980, foi a combinação bemsucedida de permanência e inovação. Como buscamos demonstrar, as inovações têm êxito porque se amparam em tradições estabelecidas, tanto da Igreja Católica quanto da própria marca da editora, o seu "carisma". Mantendo sempre o elemento religioso mesmo nos livros mais heterodoxos, ela não perde sua característica distintiva. A "abertura ao mundo" proposta a partir do Concílio Vaticano II permite que a casa sustente suas pretensões de se tornar uma editora de massas, mas católica.

Outro ponto que buscamos demonstrar ao longo dos capítulos foi a divisão de papéis de gênero dentro da editora. Enquanto as mulheres, a partir da década de 1980, trabalhavam mais diretamente com o público e com o mundo exterior à congregação por exemplo, na UCBC, no Sepac e nos círculos bíblicos -, o trabalho direto com os textos sagrados, teológicos e filosóficos ficava restrito aos homens. Essa restrição só acaba quando as editoras iniciam seu processo de separação, em 1994, e as paulinas começam a formar departamentos editoriais de Bíblia e Teologia.

Além disso, observamos como a produção de livros teve um papel fundamental na coordenação de um projeto mais amplo da Igreja Católica (ou, ao menos, de seus setores progressistas). As comunidades eclesiais de base extrapolavam o local; como vimos, havia uma tentativa de estabelecer uma coordenação nacional. Os próprios órgãos, como equipes de pastorais específicas (da juventude, operária etc.) da CNBB, de seus regionais, regiões episcopais, arquidioceses, dioceses, paróquias... Nessa coordenação, os livros não eram apenas o "fermento da massa", mas funcionavam, também, como uma 
liga para seus diferentes ingredientes. Dessa forma, a editora, ao mesmo tempo que incorpora as mudanças ocorridas na Igreja, também contribui para essa mudança.

Embora não caiba ao historiador especular sobre as intenções subjetivas dos indivíduos, é possível - e necessário - tratar dos objetivos das pessoas e instituições como agentes históricos, inseridos na vida pública. Nesse sentido, nosso estudo leva a duas questões. Por um lado, alguns religiosos, intelectuais e editores, enquanto membros da sociedade e da Igreja, ansiavam por uma sociedade política e economicamente mais justa e democrática. Por outro, a Igreja, enquanto instituição que se pretende monopolista, via nas comunidades eclesiais de base os potenciais de retenção à perda de fiéis, pelo maior engajamento nas atividades da fé; e de formação de líderes católicos que garantissem que sua religião mantivesse espaços de poder e pautasse, ainda que tangencialmente, o país. No caso das Edições Paulinas, fica claro que a maioria dos autores eram ou religiosos (sobretudo padres) ou leigos também católicos, atuantes nas pastorais.

Formava-se, assim, uma cultura de esquerda dentro da Igreja Católica, cujo ponto culminante foi a publicação da Bíblia Pastoral. Nesse sentido, percebe-se um protagonismo desses produtores e mediadores - religiosos, teólogos, tradutores, editores - na formação dessa cultura. Como afirmou Sandro da Silva, "mesmo a ideia de que se ouvia o povo, talvez já encerrasse uma idealização metafísica desse povo, como se nele não houvesse contradições, desejos e necessidades díspares e irreconciliáveis" ${ }^{476}$. Mas tal questão, é claro, não se restringe ao pensamento político produzido pela Igreja Católica. Ainda que encerrasse inúmeras contradições e que tenha sido gradualmente enfraquecida ao longo da década de 1990, essa cultura de esquerda católica não se extinguiu. A própria Bíblia Pastoral, mais radical que o projeto da Igreja progressista em geral, foi impressa por 25 anos (mesmo que sem o vocabulário original) até passar por uma nova tradução e edição em 2014.

\footnotetext{
${ }^{476}$ SILVA, Sandro Ramon Ferreira da. O Tempo das Utopias. Religião e Romantismos Revolucionários no Imaginário da Teologia da Libertação dos anos 1960 aos 1990, op. cit., p. 94.
} 
Ao mesmo tempo, a visão de mundo católica também seria marcante para a nova esquerda articulada na década de 1980, notadamente no Partido dos Trabalhadores. Décadas depois, durante os governos do PT, questões como a descriminalização do aborto continuaram sendo evitadas. Embora a religião apareça mais claramente na política quando se abordam questões de sexualidade e de gênero, não se restringe a estas. A própria cultura política brasileira, mesmo à esquerda, segue permeada por valores e argumentos religiosos. A crítica é geralmente feita, mesmo por laicos, dentro do cristianismo. O poder que os religiosos de extrema-direita - especialmente ligados às igrejas evangélicas neopentecostais, mas também à católica - assumiram nos últimos anos é comumente alvo de acusações sob a alegação de que Jesus pregava ideias e atitudes opostas. Menos comum, pasmem, é a crítica ao próprio uso de argumentos religiosos para guiar políticas de Estado. Nesse sentido, a Teologia da Libertação foi bem-sucedida. Ao fornecer uma via - por vezes mais, por vezes menos - de esquerda dentro do próprio cristianismo, ela conseguiu fazer com que a questão religiosa não fosse excluída do debate público. Para isso, contribuiu a existência de correntes mais radicais que, conquanto fossem oficialmente rechaçadas pelo episcopado, expandiam o alcance político da Igreja, ganhando o interesse e mesmo a simpatia de um público (muitas vezes, um público leitor) externo a ela.

Assim como a nova esquerda que chegou ao poder, por mais moderado que seja seu projeto, enfrentou e enfrenta grande resistência, o mesmo ocorre com a Igreja que não se identifica com o tradicionalismo nem com a renovação conservadora. Quando, em 2013, um papa relativamente mais progressista substituiu Joseph Ratzinger, começou a ocorrer um processo similar ao que se seguira ao Concílio Vaticano II, que desagradou apenas as alas ultraconservadoras da Igreja. No Brasil, essas alas remontam a associações 
como a TFP e no século XXI se expandem nos meios (sociais)midiáticos ${ }^{477}$, mas ganharam espaço especialmente a partir de 2018. Conforme o saudosismo da ditadura militar tenta se concretizar na vida pública, os setores religiosos que não se alinhem à extrema-direita (e que defendam questões tão radicais quanto o respeito aos direitos humanos básicos) voltam a ser encarados como ameaças à ordem estabelecida. Em 2019, quando bispos sulamericanos se reuniam no Vaticano, no Sínodo para a Amazônia, o homem que ocupa o cargo de presidente do Brasil afirmou que a Abin, Agência Brasileira de Inteligência, “monitorava" o evento ${ }^{478}$. Durante a campanha eleitoral de 2020, um padre de São Paulo sofreu ameaças por realizar trabalho de acolhimento à população em situação de rua da cidade. Em 2021, a Campanha da Fraternidade da CNBB foi duramente criticada por pregar o combate à pandemia, à violência e à intolerância. A Igreja Católica continua sendo, no Brasil, um ator e um espaço importante de disputas políticas. E essas disputas, é claro, também são travadas nos livros.

\footnotetext{
477 Ver, por exemplo, BARROS, Wellington da Silva de. "Fora da Igreja Não Há Salvação: Ambientes Católicos Virtuais e o Fortalecimento da Perspectiva Exclusivista". Último Andar, n. 29, pp. 32-48, 2016. ${ }^{478} I s t o E ́$, 31.8.2019. Disponível em: https://istoe.com.br/sinodo-da-amazonia-e-um-evento-politico-dizbolsonaro/
} 


\section{Fontes}

\section{Arquivo Nacional}

Fundo SNI, Série Agência Central, Informação n. 083/19/AC/83.

. Dossiê "Publicações Religiosas", 1990.

Polícia Militar do Estado de São Paulo, Informe n. PM2-1012/2.3.4/89

\section{Documentos do Vaticano}

(Disponíveis em http://www.vatican.va)

COngregaÇão Para A DOUTRINA DA FÉ. Notificação sobre a Situação do Índice de Livros Proibidos. Roma, 14 de junho de 1966.

LEÃO XIII. Carta Encíclica Rerum Novarum. Sobre a Condição dos Operários. Roma, 15 de maio de 1891.

PaUlo VI. Carta Apostólica Motu Proprio Integrae Servandae. Roma, 7 de dezembro de 1965

_. Constituição Dogmática Dei Verbum Sobre a Revelação Divina. Roma, 18 de novembro de 1965.

Constituição Dogmática Lumen Gentium Sobre a Igreja. Roma, 21 de novembro de 1964.

. Constituição Pastoral Gaudium et Spes. Sobre a Igreja no Mundo Atual. Roma, 7 de dezembro de 1965

Decreto Inter Mirifica sobre os Meios de Comunicação Social. Vaticano, 4 de dezembro de 1963. 
Discorso ai Partecipanti al Capitolo Generale della Pia Società San Paolo. Ariccia, 28 de junho de 1969.

PIO XI. Quamvis Nostra. All'em.mo Cardinale Presbitero Sebastiano Leme de Silveira Cintra Arcivescovo di San Sebastiano di Rio de Janeiro sulla Carenza di Sacerdoti in Brasile. Roma, 27 de outubro de 1935.

Pontifício CONSElHo PARA AS COMUNICAÇÕES SOCIAIS. Instrução Pastoral Communio et Progressio sobre os Meios de Comunicação Social Publicada por Mandato do Concilio Ecuménico II do Vaticano. Roma, 23 de maio de 1971.

\section{Paulus Editora - Arquivo do Departamento de Direitos Autorais}

Carta de Abramo Parmeggiani a Haroldo Galvão, 31.8.1984.

Cartas e Contratos com Carmelo Imaculado Coração de Maria e Santa Teresinha, 19811988.

Contrato de Edição de A Humanidade Caminha Para a Fraternidade, de Paulo Evaristo Arns, 30.11.1968.

Contrato de Tradução da Bíblia de Jerusalém, assinado por Gabriel Ferrier, directeur commerciel et financier de Les Éditions du Cerf, e Carlos D. Vido, chefe do departamento editorial das Edições Paulinas, Paris, 10.4.1972.

Contrato de Edição de Esta Juventude Magnífica e Seus Namoros Nem Sempre Maravilhosos..., de José Fernandes de Oliveira, 23.6.1976.

Contrato de Tradução de Oração Diária com a Bíblia, assinado por Pe. Eduardo Dougherty, representante da Comissão Nacional de Serviço da Renovação Carismática Católica, e Carlos Vido, Edições Paulinas, 24.6.1976.

Contrato de Edição entre CNBB e Edições Paulinas, assinado por Ir. Tarcilla Tommasi em São Paulo, 14-12-1973 e Dom José Ivo Lorscheiter no Rio de Janeiro, 18.12.1973. 
Contratos de Edição entre CNBB e Edições Paulinas, assinado por Aloísio Lorscheider, 30.11.1970.

Contratos de Edição da Coleção O Problema É... entre Edições Paulinas, Haroldo Galvão e Carlos Afonso Schmitt, 1973.

\section{Periódicos}

A Imprensa. Semanário Católico Popular. São Paulo, 10.10.1957.

A Lanterna: Jornal de Combate ao Clericalismo. São Paulo, n. 396, 1.6.1935.

Diário Oficial do Estado de São Paulo. São Paulo, 12.5.1979.

Família Cristã. São Paulo, março de 1974.

Folha da Noite. São Paulo, 26.1.1939.

Folha de S. Paulo. São Paulo, 3.9.1977; 30.6.1985; 12.9.1986; 19.9.1986.

IstoÉ. 31.8.2019.

Jornal do Dia. Porto Alegre, 25.5.1947; 26.10.1947; 18.12.1954; 10.4.1955; 1.1.1956;

4.5.1956; 1.5.1958; 10.9.1959; 12.1959; 14.1.1960; 26.5.1960; 8.10.1960; 30.12.1960; 26.9.1965.

La Civiltà Cattolica. Roma, anno 69, vol. II, 1918.

La Squilla. Settimanale per il Popolo. São Paulo, n. 37, 29.11.1911.

La Squilla. Settimanale Cattolico. São Paulo, n. 6, 7.2.1934.

Leia Livros, São Paulo, n. 25, junho/julho de 1980; n. 26, julho/agosto de 1980; n. 33, março/abril de 1981; n. 72, outubro de 1984; n. 80, junho de 1985; n. 92, junho de 1986.

O Cooperador Paulino. São Paulo, Ano 48, n. 1, 1981; Ano 58, n. 38, set.-dez. 1991.

O Domingo. Semanário Religioso para as Famílias. São Paulo, Número Extraordinário, jan. 1937; Ano v, n. 15, 11.4.1937; Ano v, n. 37, 12.9.1937. 
O Estado de S. Paulo, 8.3.1995.

Unione Cooperatori Buona Stampa. Alba, Anno II, n. 7, 1919; Anno III, n. 6, 1920; Anno III, n. 7, settembre 1920.

\section{Entrevistas e Depoimentos}

Claudiano Avelino dos Santos, 1.4.2019.

Luiz Miguel Duarte, 4.4.2019.

Vera Ivanise Bombonatto, 12.4.2019. 


\section{Bibliografia}

A Bíblia de Jerusalém. São Paulo, Edições Paulinas, 1981.

D’Ableiges, Pe. Xavier G. de M. Curso Bíblico para as Comunidades Eclesiais de Base. São Paulo, Edições Paulinas, 1976.

Agnelo, Geraldo Majella; Krohling, Aloísio; Pereira, Décio \& Schirato, Sérgio José. Pastoral do Batismo. Subsídio Teológico e Litúrgico. 2. ed. São Paulo, Edições Paulinas, 1971. (Maturidade Cristã, 1).

Alberione, Santiago. Abundantes Divitiae Gratiae Suae. História Carismática da Família Paulina. São Paulo, Paulus, 2000.

El Apostolado de la Edición. Manual Directivo de Formación y de Apostolado. [s.

1.], San Pablo, 1998.

Alicino, Rogério, pime. Comunidade, Líder, Paróquia. São Paulo, Edições Paulinas, 1977. (Igreja Dinâmica).

AlvarengA, Ricardo Costa. "A Comunicação da Igreja Católica no Brasil: Criação e Evolução da Comissão Episcopal de Opinião Pública”. Pensacom Brasil, São Paulo, dez. 2017.

A Comunicação da Igreja Católica no Brasil: Tendências Comunicacionais da Conferência Nacional dos Bispos do Brasil. Dissertação de Mestrado em Comunicação Social, Universidade Metodista de São Paulo, São Bernardo do Campo, 2016.

ANNUARIO Pontificio per l'Anno 1979. Città del Vaticano, Libraria Editrice Vaticana, 1979.

Araújo, Emanuel. A Construção do Livro. Princípios da Técnica de Editoração. Rio de Janeiro/Brasília, Nova Fronteira/Instituto Nacional do Livro, 1986. 
ARDUINI, Juvenal. Horizonte de Esperança: Teologia da Libertação. São Paulo, Edições Paulinas, 1986. (Fermento na Massa).

D’ARns, Hugues (org.). Mulher: da Escravidão à Libertação. São Paulo, Edições Paulinas, 1989. (Pastoral e Comunidade).

Arquidiocese de VitóRIA. Bate-Papo sobre Política II: Como Funciona a Sociedade. Desenhos de Fabiano. São Paulo, Edições Paulinas, 1982. (Cadernos de Base, 5). AZZI, Riolando \& VAN DER GRIJP, Klaus. História da Igreja no Brasil. Ensaio de Interpretação a Partir do Povo. Petrópolis, Vozes, 2008, tomo II, vol. 3 (Terceira Época: 1930-1964).

Balancin, Euclides Martins. História do Povo de Deus. São Paulo, Edições Paulinas, 1990. (Como Ler a Bíblia).

\& Storniolo, Ivo. Como Ler o Livro de Miqueias: Um Profeta Contra o Latifúndio. São Paulo, Edições Paulinas, 1990. (Como Ler a Bíblia).

Baldissera, Adelina. CEBs: Poder, Nova Sociedade. São Paulo, Edições Paulinas, 1987. (Fermento na Massa).

BARros, Wellington da Silva de. "Fora da Igreja Não Há Salvação: Ambientes Católicos Virtuais e o Fortalecimento da Perspectiva Exclusivista”. Último Andar, n. 29, pp. 32-48, 2016.

Benedetti, Luiz Roberto. Templo, Praça, Coração: A Articulação do Campo Religioso Católico. São Paulo, Humanitas, 2000.

BEozzo, José Oscar. A Igreja do Brasil no Concílio Vaticano II: 1959-1965. São Paulo, Paulinas, 2005.

. “A Recepção do Vaticano II na Igreja do Brasil”. In: Instituto NACIONAL DE Pastoral (org.). Presença Pública da Igreja no Brasil (1952-2002): Jubileu de Ouro da CNBB. São Paulo, Paulinas, 2003. 
BetTo, Frei. Batismo de Sangue: Os Dominicanos e a Morte de Carlos Marighella. Rio de Janeiro, Civilização Brasileira, 1982. Les Frères de Tito. Paris, Éditions du Cerf, 1984.

. O Que É Comunidade Eclesial de Base. São Paulo, Brasiliense, 1981. (Primeiros Passos, 19).

Bíblia de Jerusalém. Nova Edição Revista e Ampliada. São Paulo, Paulus, 2002.

Bíblia Sagrada. Vol. IV: Novo Testamento. Traduzido da Vulgata e anotado pelo Pe. Matos Soares. São Paulo, Pia Sociedade de São Paulo, 1949.

Bíblia Sagrada. Edição Pastoral. 2. Impressão [abril de 1990]. São Paulo, Edições Paulinas, 1990.

Bittencourt, Agueda Bernardete. "O Livro e o Selo: Editoras Católicas no Brasil”. ProPosições, vol. 25, n. 1 (73), jan.-abr. 2014, pp. 117-137.

Boff, Leonardo. Jesus Cristo Libertador: Ensaio de Cristologia Crítica para o Nosso Tempo. Petrópolis, Vozes, 2012.

BORAN C.S.sp., Pe. Jorge. Curso de Treinamento para Lideranca (CTL). São Paulo, Edições Paulinas, 1994. (Igreja Dinâmica).

Juventude: O Grande Desafio. São Paulo, Edições Paulinas, 1982. (Igreja Dinâmica).

Bortolini, José. Como Ler a Primeira Carta aos Coríntios: Superar os Conflitos em Comunidade. São Paulo, Edições Paulinas, 1992. (Como Ler a Bíblia).

_. Como Ler a Primeira Carta aos Tessalonicenses: Fé, Amor, Esperança. São Paulo, Edições Paulinas, 1991. (Como Ler a Bíblia). . Como Ler a Segunda Carta aos Coríntios: O Agente de Pastoral e o Poder. São Paulo, Edições Paulinas, 1992. (Como Ler a Bíblia). 
Bosi, Ecléa. Cultura de Massa e Cultura Popular: Leituras de Operárias. Petrópolis, Vozes, 1972.

BouRdiEu, Pierre. A Economia das Trocas Simbólicas. Introdução, organização e seleção de Sergio Miceli. São Paulo, Perspectiva, 2015. (Estudos, 20). As Regras da Arte. Gênese e Estrutura do Campo Literário. São Paulo, Companhia das Letras, 1996.

. “L’Opinion Publique n’Existe pas”. Les Temps Modernes, n. 318, pp. 1292-1309, 1973.

. "Séminaires sur le Concept de Champ, 1972-1975. Introduction de Patrick Champagne". Actes de la Recherce en Sciences Sociales, n. 200, pp. 4-37, 2013. . “Uma Revolução Conservadora na Edição". Política \& Sociedade, vol. 17, n. 19, pp. 198-249, 2018.

\& SAInT-Martin, Monique de. “La Sainte Famille. L’Épiscopat Français dans le Champ du Pouvoir". Actes de la Recherche en Sciences Sociales, vol. 44-45, 1982. BRANDÃo, Walmir Fernandes Panela de Opressão. Juventude: da Opressão do Cativeiro à Libertação. São Paulo, Edições Paulinas, 1979. (Igreja Dinâmica).

Brant, Vinícius Caldeira \& Singer, Paul (org.). São Paulo: O Povo em Movimento. Petrópolis, Vozes, 1980.

BRASIL, Monsenhor Francisco de Sales. As Fontes do Divórcio. 2. ed. São Paulo, Edições Paulinas, 1954.

Brito, Fernando de; Lesbaupin, Ivo \& Christo, Carlos Alberto Libânio [Frei Betto]. $O$ Canto na Fogueira: Cartas de Três Dominicanos quando em Cárcere Político. Prefácio de Carlos Mesters. Petrópolis, Vozes, 1978.

BrunEau, Thomas. Catolicismo Brasileiro em Época de Transição. São Paulo, Loyola, 1974. 
BujANDA, Jésus Martínez de \& RichTER, Marcella. Index Librorum Prohibitorum 16001966. Montréal, Médiaspaul, 2002.

Calvez, Jean-Yves. El Pensamiento de Carlos Marx. Madrid, Taurus, 1958.

Canellas, Antonio Bernardo. Questões Profissionais da Indústria do Livro. São Paulo, Com-Arte, 2016.

CANFora, Luciano. A Biblioteca Desaparecida. Histórias da Biblioteca de Alexandria. São Paulo, Companhia das Letras, 1989.

CANTAREla, Antônio Geraldo. “Tradução de Textos Bíblicos para a Linguagem Popular: A Experiência do Centro Bíblico de Belo Horizonte”. Perspectivas Teológicas, Belo Horizonte, vol. 52, n. 1, p. 115-141, jan.-abr. 2020.

Chartier, Roger. A Mão do Autor e a Mente do Editor. São Paulo, Editora Unesp, 2014. . Os Desafios da Escrita. São Paulo, Editora Unesp, 2002.

CNBB - Conferência Nacional dos Bispos do Brasil. Exigências Cristãs de uma Ordem Política. São Paulo, Edições Paulinas, 1977. (Documentos da CNBB, 10), __. Plano de Emergência para a Igreja do Brasil. 2. ed. São Paulo, Paulinas, 2004. . Plano de Pastoral de Conjunto 1966-1970. 2. ed. São Paulo, Paulinas, 2004.

Colistete, Renato Perim. "Salários, Produtividade e Lucros na Indústria Brasileira, 1945-1978”. Revista de Economia Política, vol. 29, n. 4, out.-dez. 2009.

COMISSÃO NACIONAL da VerdAdE. "Violações de Direitos Humanos nas Igrejas Cristãs". In: Relatório da Comissão Nacional da Verdade, vol. 2, 2014.

COnSElho Episcopal Latino-Americano. Evangelização no Presente e no Futuro da América Latina. Conclusões da Conferência de Puebla. Texto Oficial. São Paulo, Edições Paulinas, 1979. 
Presença da Igreja na Atual Transformação da América Latina à Luz do Concílio

Vaticano II. Conclusões da II Conferência Geral do Episcopado LatinoAmericano. Medellín, 1968.

CoRAZZA, Helena. Educomunicação: Caminhos e Perspectivas na Formação Pastoral. A Experiência do Serviço à Pastoral de Comunicação (Sepac). Tese de Doutorado em Ciências da Comunicação, Universidade de São Paulo, 2015,

Couto, Cláudio Gonçalves. "Mudança e Crise: O PT no Governo em São Paulo". Lua Nova, n. 33, ago. 1994.

Cristofolini imc, Pe. Hilário. Deus Mora na Contramão. 4. ed. São Paulo, Edições Paulinas, 1977. (Coleção Vida).

CunhA, Magali Nascimento. "A Revista Paz e Terra: Um Lugar de Memória da Comunicação Religiosa, Ecumênica e Política no Brasil”. Horizonte, vol. 18, n. 56, pp. 513-541, maio-ago. 2020.

Dalmolin, Aline Roes. O Discurso sobre Aborto em Revistas Católicas Brasileiras: Rainha e Família Cristã (1980-1990). Tese de Doutorado em Comunicação, Unisinos, São Leopoldo, 2012.

Damino, Andrea. Don Alberione al Concilio Vaticano II. Proposte, Interventi e Appunti. II Edizione Corretta ed Accresciuta. Roma, Edizioni dell'Archivio Storico Generale della Famiglia Paolina, 2005.

Darnton, Robert. O Beijo de Lamourette. Mídia, Cultura e Revolução. São Paulo, Companhia das Letras, 1990.

Della CaVa, Ralph. "Política de Curto Prazo e Religião de Longo Prazo: Uma Visão da Igreja Católica no Brasil”. Encontros com a Civilização Brasileira, n. 1, 1978, pp. 242-258. 
. \& Montero, Paula. E o Verbo se Faz Imagem: Igreja Católica e os Meios de Comunicação no Brasil, 1962-1989. Petrópolis, Vozes, 1991.

DestÉFAnI, Frei Benvindo. Gravetos e Fagulhas! Porto Alegre, Pia Sociedade São Paulo, 1941.

_. Gravetos e Fagulhas! São Paulo, Edições Paulinas, 1948.

Didoné, Iraci Maria. Cadernos das CEBs: Espaço de Participação? Estudo das Publicações de Edições Paulinas de Autoria e Uso das CEBs. Dissertação de Mestrado em Comunicação, Universidade de São Paulo, 1989.

Doutrina Cristã. São Paulo, Edições Paulinas, 1961.

Dussel, Enrique. Caminhos de Libertação Latino-Americana. São Paulo, Edições Paulinas, 1985, 4 vols. (Estudos \& Debates Latino-Americanos, 6-9).

. História da Igreja Latino-Americana (1930-1985). São Paulo [Caxias do Sul], Edições Paulinas, 1989.

Eco, Umberto. Apocalípticos e Integrados. São Paulo, Perspectiva, 1979.

Fausto, Boris (org.). História Geral da Civilização Brasileira. Rio de Janeiro, Bertrand Brasil, 2007, t. III (O Brasil Republicano), vol. 11 (Economia e Cultura [19301964J).

FÁvero, Osmar. "MEB - Movimento de Educação de Base. Primeiros Tempos: 19611966”. V Encontro Luso-Brasileiro de História da Educação, Évora, 5 a 8 de abril de 2004.

Febvre, Lucien \& Martin, Henri-Jean. O Aparecimento do Livro. São Paulo, Edusp, 2017.

FontanA, Josep. El Siglo de la Revolución. Una Historia del Mundo desde 1914. Barcelona, Crítica, 2017. 
Frota, José Tumpynambá da. História de Sobral. Fortaleza, Pia Sociedade de São Paulo, 1953-1954.

GaliLEA, Segundo. Teologia da Libertação: Ensaio de Síntese. 2. ed. São Paulo, Edições Paulinas, 1979. (Libertação Teológica, 1).

Garrard-BurnetT, Virginia. "A Vida Abundante: A Teologia da Prosperidade na América Latina". História: Questões \& Debates, n. 55, vol. 2, 2011.

GenetTe, Gérard. Paratextos Editoriais. Cotia, Ateliê, 2009.

Glori, Cristina. A Porta Aberta. São Paulo, Edições Paulinas, 1962. (Nova Série Primavera).

Gohn, Carlos \& Nascimento, Lyslei (org.). A Bíblia e suas Traduções. São Paulo, Humanitas, 2009.

Gomes, Paulo César. Os Bispos Católicos e a Ditadura Militar Brasileira. A Visão da Espionagem. Rio de Janeiro, Record, 2014.

GonçAlves, Leandro Pereira \& CAldeIRA Neto, Odilon. O Fascismo em Camisas Verdes: Do Integralismo ao Neointegralismo. Rio de Janeiro, FGV, 2020.

Gonçalves, Paulo Sérgio Lopes \& Bombonatto, Vera Ivanise (org.). Concílio Vaticano II: Análise e Prospectivas. São Paulo, Paulinas, 2004.

GoREnder, Jacob. Combate nas Trevas. A Esquerda Brasileira: das Ilusões Perdidas à Luta Armada. 5. ed. São Paulo, Expressão Popular/Fundação Perseu Abramo, 2014.

Gramsci, Antonio. Cadernos do Cárcere. 2. ed. Edição, Organização e Tradução de Carlos Nelson Coutinho, Luiz Sérgio Henriques e Marco Aurélio Nogueira. Rio de Janeiro, Civilização Brasileira, 2007, 6 vols. Os Intelectuais e a Organização da Cultura. 4. ed. Trad. Carlos Nelson Coutinho. Rio de Janeiro, Civilização Brasileira, 1982. 
GuRGEL, Eduardo Amaral. Imprensa e Igreja Católica no Início do Século XX: Convergências e Divergências. Tese de Doutorado em Comunicação Social, Universidade Metodista de São Paulo, 2017.

Habermas, Jürgen. Mudança Estrutural da Esfera Pública. São Paulo, Unesp, 2014.

Hallewell, Laurence. O Livro no Brasil: Sua História. São Paulo, Edusp, 2012.

Hansen, João Adolfo. O Que É um Livro? Cotia/São Paulo, Ateliê/Edições Sesc, 2019 (Bibliofilia, 1).

Hinkelammert, Franz. As Armas Ideológicas da Morte. São Paulo, Edições Paulinas, 1983. (Pesquisa \& Projeto, 6).

\& Assman, Hugo. A Idolatria do Mercado. Petrópolis, Vozes, 1989. (Teologia e Libertação, Série V - Desafios na Sociedade, 5).

IDÍGORAS, J. L. [José Luís]. Vocabulário Teológico para a América Latina. São Paulo, Edições Paulinas, 1983.

IRMÃS Paulinas. 1931-1981. 50 Anos a Serviço do Evangelho. Coordenação geral de Irmã Stefanina Cillario, fsp. São Paulo, Edições Paulinas, 1981.

Jaguaribe, Hélio; Ferrer, Aldo; WionczeK, Miguel S. \& SAntos, Theotônio dos. A Dependência Político-Econômica da América Latina. São Paulo, Loyola, 1976. JoÃo, Wilson. O Francisco que Está em Você. Vida de São Francisco de Assis Narrada para o Homem de Hoje. 5. ed. São Paulo, Edições Paulinas, 1979.

KECK, Margareth E. PT: A Lógica da Diferença. O Partido dos Trabalhadores na Construção da Democracia Brasileira. São Paulo, Ática, 1991.

Khoury, Yara Aun (org.). Guia de Pesquisa: Igreja e Movimentos Sociais. São Paulo, Com-Arte/Cedic, 1991. 
KLAUCK, Samuel. “A Imprensa como Instrumento de Defesa da Igreja Católica e de Reordenamento dos Católicos no Século XIX”. Mneme - Revista de Humanidades, n. 11, vol. 29, pp. 132-148, jan.-jul. 2011.

KLEIN, Herbert S. "A Integração dos Imigrantes Italianos no Brasil, na Argentina e Estados Unidos”. Novos Estudos Cebrap, n. 25, pp. 95-117, out. 1989.

KLOPPENBURG, Boaventura. "Bispo Jubilar com suas Vicissitudes Eclesiais". Teocomunicação, Porto Alegre, vol. 37, n. 158, pp. 508-524, dez. 2007.

Konings, Johan. “Traduções Bíblicas Católicas no Brasil (2000-2015)”. Pistis \& Praxis: Teologia e Pastoral, vol. 8, n. 1, pp. 89-102, jan.-abr. 2016.

Krischke, Paulo \& Mainwaring, Scott (org.). A Igreja Nas Bases Em Tempo de Transição (1974-1985). Porto Alegre, L\&PM, 1986.

LAJolo, Marisa \& ZiLberman, Regina. A Formação da Leitura no Brasil. São Paulo, Ática, 1996.

LANZA, Fabio. Matrizes Ideológicas dos Arcebispos Paulistanos (1956-85): Um Olhar sob o Prisma do Semanário O São Paulo. Tese de Doutorado em Ciências Sociais, Pontifícia Universidade Católica de São Paulo, 2006.

LEMINSKI, Paulo. Vida. São Paulo, Companhia das Letras, 2013.

LEUENROTH, Edgard. A Organização dos Jornalistas Brasileiros, 1908-1951. São Paulo, Com-Arte, 1987.

LiMA, Delcio Monteiro de. Os Demônios Descem do Norte. Rio de Janeiro, Francisco Alves, 1987.

Lima, Haroldo \& ARANTES, Aldo. História da Ação Popular: da JUC ao PCdoB. 2. ed. São Paulo, Alfa-Omega, 1984.

Lovatto, Angélica. "Ênio Silveira e os Cadernos do Povo Brasileiro". Lutas Sociais, São Paulo, n. 23, pp. 93-103, 2009. 
LöwY, Michael. The War of Gods. Religion and Politics in Latin America. London/New York, Verso, 1996.

LuXEMBurgo, Rosa. “A Igreja e o Socialismo” [1905]. Textos Escolhidos, vol. 1 (18991914). Organização de Isabel Loureiro. São Paulo, Unesp, 2018.

Mainwaring, Scott. A Igreja Católica e a Política no Brasil (1916-1985). São Paulo, Brasiliense, 2004.

Macedo, Carmen Cinira de Andrade. Tempo de Gênesis: O Povo das Comunidades Eclesiais de Base. São Paulo, Brasiliense, 1986.

Machado, Adriano Henriques. Os Católicos opTaram? Os "Setores Católicos" e o Partido dos Trabalhadores (PT) na Grande São Paulo (1978-1982). Dissertação de Mestrado em História, PUC-SP, 2010.

Mariano, Ricardo. Neopentecostais: Sociologia do Novo Pentecostalismo no Brasil. São Paulo, Loyola, 1999.

Martini, Catarina A. As Filhas de São Paulo: Anotações para uma História (19151984). São Paulo, Paulinas, 1995.

MARTINS, Carlos Benedito. “A Reforma Universitária de 1968 e a Abertura para o Ensino Superior Privado no Brasil". Educação \& Sociedade, vol. 30, n. 106, jan.-abr. 2009.

MAUÉs, Flamarion. Livros Contra a Ditadura: Editoras de Oposição no Brasil, 19741984. São Paulo, Publisher Brasil, 2013.

. "Livros, Editoras e Oposição à Ditadura". Estudos Avançados, vol. 28, n. 80, pp. 91-104, 2014.

Mazzel, Maximiliano. Amor e Felicidade. São Paulo, Edições Paulinas, 1957. (Série Primavera).

McKenZIE, D. F. Bibliografia e Sociologia dos Textos. São Paulo, Edusp, 2018. 
Melot, Michel. Livro,. Cotia, Ateliê Editorial, 2012.

MendonçA, Antonio Gouvêa. O Celeste Porvir: A Inserção do Protestantismo no Brasil. São Paulo, Edições Paulinas, 1984. (Estudos \& Debates Latino-Americanos, 10). Merlo, Tecla. Un Cuor Solo, un'Anima Sola. Conferenze - Meditazioni 1954-1963. Roma, Edizioni Paoline, 1993.

Miceli, Sergio. A Elite Eclesiástica Brasileira. Rio de Janeiro, Bertrand, 1988. Intelectuais e Classe Dirigente no Brasil (1920-1945). São Paulo, Difel, 1979.

MonteIRo, Lorena Madruga. “O Resto Não é Silêncio. Polêmica e Polarização do Campo Intelectual em Porto Alegre nos anos 1940”. Perspectivas, São Paulo, vol. 40, pp. 121-143, jul./dez. 2011.

Montero, Paula. "O Papel das Editoras Católicas na Formação Cultural Brasileira”. In: SANCHIS, Pierre (org.). Catolicismo: Modernidade e Tradição. São Paulo, Loyola, 1992.

Nascimento, Maria Natividade Pereira do. A Religiosidade Popular na Revista Família Cristã: Uma Análise das Matérias que Aparecem na Seção Cultura Popular das edições de 1980 a 1981. Dissertação de Mestrado em Ciências da Religião, PUCSP, 2007.

Neves, Ozias Paese. Imaginários e Utopias na Passagem entre Ditadura $e$ Redemocratização: O Momento Constituinte em Cartilhas (1985-1988). Tese de Doutorado em História, Universidade Federal do Paraná, 2017.

NOVA Bíblia Pastoral. São Paulo, Paulus, 2014.

Nunes, Maria José Rosado. "Freiras no Brasil". In: PrIORE, Mary del \& BASSANEZI, Carla (org.). História das Mulheres no Brasil. 7. ed. São Paulo, Contexto, 2004.

Olivero, Isabelle. L'Invention de la Collection. Paris, Éditions de l'Imec/Maison des Sciences de l'Homme, 1999. 
OUVRY-Vial, Brigitte. “L’Acte Editorial: Vers une Théorie du Geste”. Communication et Langages, n. 154, pp. 67-82, 2007.

PAIVA, José Maria de. A Imagem que a Igreja Tem da Realidade Brasileira. Um Estudo Através das Comunidades Eclesiais de Base - CEBs. Tese de Doutorado em Educação, Universidade Estadual de Campinas, 1985.

PANINI, Carmela. Reforma Agrária Dentro e Fora da Lei: 500 Anos de História Inacabada. São Paulo, Edições Paulinas, 1990. (Fermento na Massa).

PÉreZ, Claudio Jesús \& MurPhy, John W. "El Trabajo del Departamento Ecuménico de Investigaciones y América Latina”. Comunicación, Cultura y Política. Revista de Ciencias Sociales, n. 4, jul.-dez. 2011.

PIVATO, Stefano. “L'Organizzazione Cattolica della Cultura di Massa Durante il Fascismo". Italia Contemporanea, vol. 30, n. 132, 1978.

PRANDI, Reginaldo. Um Sopro do Espírito: A Renovação Conservadora do Catolicismo Carismático. 2. ed. São Paulo, Edusp/Fapesp, 1998.

Programa Lugares da Memória. Livraria Duas Cidades. São Paulo, Memorial da Resistência de São Paulo, 2015.

PunTel, Joana. Comunicação: Diálogo dos Saberes na Cultura Midiática. São Paulo, Paulinas, 2010. Igreja e Sociedade: Método de Trabalho na Comunicação. São Paulo, Paulinas, 2015.

_. Pastoral da Comunicação: Diálogo entre Fé e Cultura. São Paulo, Paulinas, 2007. REGAN, David. Igreja para a Libertação: Retrato Pastoral da Igreja no Brasil. São Paulo, Edições Paulinas, 1986. (Fermento na Massa).

REgI, Glória. Missal. São Paulo, Edições Paulinas, 1958. 
REIMÃo, Sandra. Mercado Editorial Brasileiro: 1960-1990. São Paulo, ComArte/Fapesp, 1996.

. “'Proíbo a Publicação e Circulação...' - Censura a Livros na Ditadura Militar”. Estudos Avançados, vol. 28, n. 80, jan.-abr. 2014.

_. Repressão e Resistência: Censura a Livros na Ditadura Militar. Tese de LivreDocência, Universidade de São Paulo, 2011.

\& CREnI, Gisela (org.). Caio Graco Prado e a Editora Brasiliense. São Paulo, Biblioteca Brasiliana Guita e José Mindlin, 2020.

RICHARD, Pablo. A Igreja Latino-Americana entre o Temor e a Esperança: Apontamentos Teológicos para a Década de 80. São Paulo, Edições Paulinas, 1982. (Libertação e Teologia, 19).

RIDENTI, Marcelo \& REIS, Daniel Aarão (org.). História do Marxismo no Brasil. Vol. 6: Partidos e Movimentos Após os Anos 1960. Campinas, Editora da Unicamp, 2007. Rodrigues, Cátia Regina. A Arquidiocese de São Paulo na Gestão de D. Paulo Evaristo Arns (1970-1990). Dissertação de Mestrado em História Social, Universidade de São Paulo, 2008.

Rolfo, Luís. Padre Alberione. Anotações para uma Biografia. $2^{a}$ ed. São Paulo, Paulus, 2001.

Rosario, Fray Pedro Corro del. Gonzalo de Berceo. Estudio Critico-Literario. São Paulo, Pia Sociedade de São Paulo/Tipografia de La Squilla, 1933.

Ruffato, Luiz. Inferno Provisório. São Paulo, Companhia das Letras, 2016.

SADER, Eder. Quando Novos Personagens Entraram em Cena: Experiências, Falas e Lutas dos Trabalhadores da Grande São Paulo 1970-1980. Rio de Janeiro, Paz e Terra, 1988. 
SAlles, Paula Ribeiro. Documentação e Comunicação Popular: A Experiência do CPVCentro de Pastoral Vergueiro (São Paulo/SP, 1973-1989). Dissertação de Mestrado em História Social, Pontifícia Universidade Católica de São Paulo, 2013.

SCHMitT, Carlos Afonso. O Importante É Cativar(-se): A Arte de Fazer Amigos e Gostar de Si. 12. ed. São Paulo, Edições Paulinas, 1987 [1. ed. 1979]. (Encontro). Quem Ama se Compromete: Para os que Não Têm Medo da Verdade. São Paulo, Edições Paulinas, 1975. (Compromisso).

SchwarZ, Roberto. As Ideias Fora do Lugar: Ensaios Selecionados. São Paulo, Companhia das Letras, 2014.

SECCO, Lincoln. História do PT. 5. ed. Cotia, Ateliê, 2018.

SENRA, Alvaro de Oliveira. “CNBB, Democracia e Participação Popular (1977-1989)”. Anos 90, Porto Alegre, vol. 24, n. 46, dez. 2017, pp. 97-120.

SERBIN, Kenneth P. Diálogos na Sombra: Bispos e Militares, Tortura e Justiça Social na Ditadura. São Paulo, Companhia das Letras, 2001. . Padres, Celibato e Conflito Social: Uma História da Igreja Católica no Brasil. São Paulo, Companhia das letras, 2008.

SILVA, Jomar Ricardo da. "O Rendilhado de Poderes e Tensões. As Inter-relações de Animadores e Agentes de Pastoral nas CEBs”. Revista Eclesiástica Brasileira, n. 62, vol. 247, pp. 576-603, 2002.

Silva, Sandro Ramon Ferreira da. O Tempo das Utopias. Religião e Romantismos Revolucionários no Imaginário da Teologia da Libertação dos anos 1960 aos 1990. Tese de doutorado em História Social, Universidade Federal Fluminense, 2013. 
Silva Gotay, Samuel. O Pensamento Cristão Revolucionário na América Latina e no Caribe (1960-1973): Implicações da Teologia da Libertação para a Sociologia da Religião. São Paulo, Edições Paulinas, 1985. (Estudos \& Debates LatinoAmericanos, 15).

SINZIG, Pedro. Através dos Romances: Guia para as Consciências. Petrópolis, Vozes de Petrópolis, 1915 [2. ed. 1923].

SKIDMORE, Thomas. Brasil: De Castelo a Tancredo. Rio de Janeiro, Paz e Terra, 1988.

SYdow, Evanize \& FerRI, Marilda. Dom Paulo: Um Homem Amado e Perseguido. São Paulo, Expressão Popular, 2017.

SOARES, Edvaldo. Pensamento Católico Brasileiro: Influências e Tendências. Marília/São Paulo, Oficina Universitária/Cultura Acadêmica, 2014.

SoARES, Ismar de Oliveira. Do Santo Ofício à Libertação: O Discurso e a Prática do Vaticano e da Igreja Católica no Brasil sobre a Comunicação Social. São Paulo, Edições Paulinas, 1988. (Comunicação Social). \& PunTel, Joana (org.). Comunicação, Igreja e Estado na América Latina. XIII Congresso da UCBC. São Paulo, Edições Paulinas/UCBC, 1985.

TAgore, Rabindranath. A Colheita. Trad. Ivo Storniolo. São Paulo, Edições Paulinas, 1990.

Taubaté, Modesto Rezende de \& Primiero, Fidelis Motta. Os Missionários Capuchinhos no Brasil. Esboço Histórico. São Paulo, Tipografia do Semanário La Squilla, 1929.

THE 1917 or Pio-Benedictine Code of Canon Law. Translated and edited by Edward N. Peters. San Francisco, Ignatius Press, 2001.

ThOMPSON, John B. Mercadores de Cultura: O Mercado Editorial no Século XXI. São Paulo, Unesp, 2013. 
TORRES, Sérgio (org.). A Igreja que Surge da Base. Eclesiologia das Comunidades Cristãs de Base. São Paulo, Edições Paulinas, 1982. (Libertação e Teologia, 11). TrAnIELlO, Francesco. “L'Editoria Cattolica tra Libri e Reviste”. In: TURI, Gabriele (org.). Storia dell'Editoria nell'Italia Contemporanea. Florença, Giunzi, 1997. Trento, Angelo. Do Outro Lado do Atlântico: Um Século de Imigração Italiana no Brasil. São Paulo, Nobel, 1989.

VAlerio, Adriana. A Presença Feminina no Vaticano II. As 23 Mulheres do Concílio. São Paulo, Paulinas, 2014.

VIDAS Que Valeram a Pena (1931-2014). São Paulo, Padres e Irmãos Paulinos, 2014.

VIEIRA, Dilermando Ramos. O Processo de Reforma e Reorganização da Igreja no Brasil (1844-1926). Aparecida, Santuário, 2007.

ZeZINHo scj, Padre [José Fernandes de Oliveira]. Alicerce Para um Mundo Novo: A Fé Explicadas aos Jovens. São Paulo, Edições Paulinas, 1971. . A Revolta e a Paz de Maria Helena. São Paulo, Edições Paulinas, 1977. (Alicerce, $6)$.

__. Esta Igreja Magnífica e seus Leigos Maravilhosos. São Paulo, Edições Paulinas, 1976. (Compromisso, 5).

Esta Juventude Magnífica e Seus Namoros Nem Sempre Maravilhosos... São Paulo, Edições Paulinas, 1976. (Compromisso, 9). 